\title{
CO-DESIGNING INTEGRATED PEST AND DISEASE MANAGEMENT STRATEGIES IN EGGPLANT PRODUCTION IN BANGLADESH
}

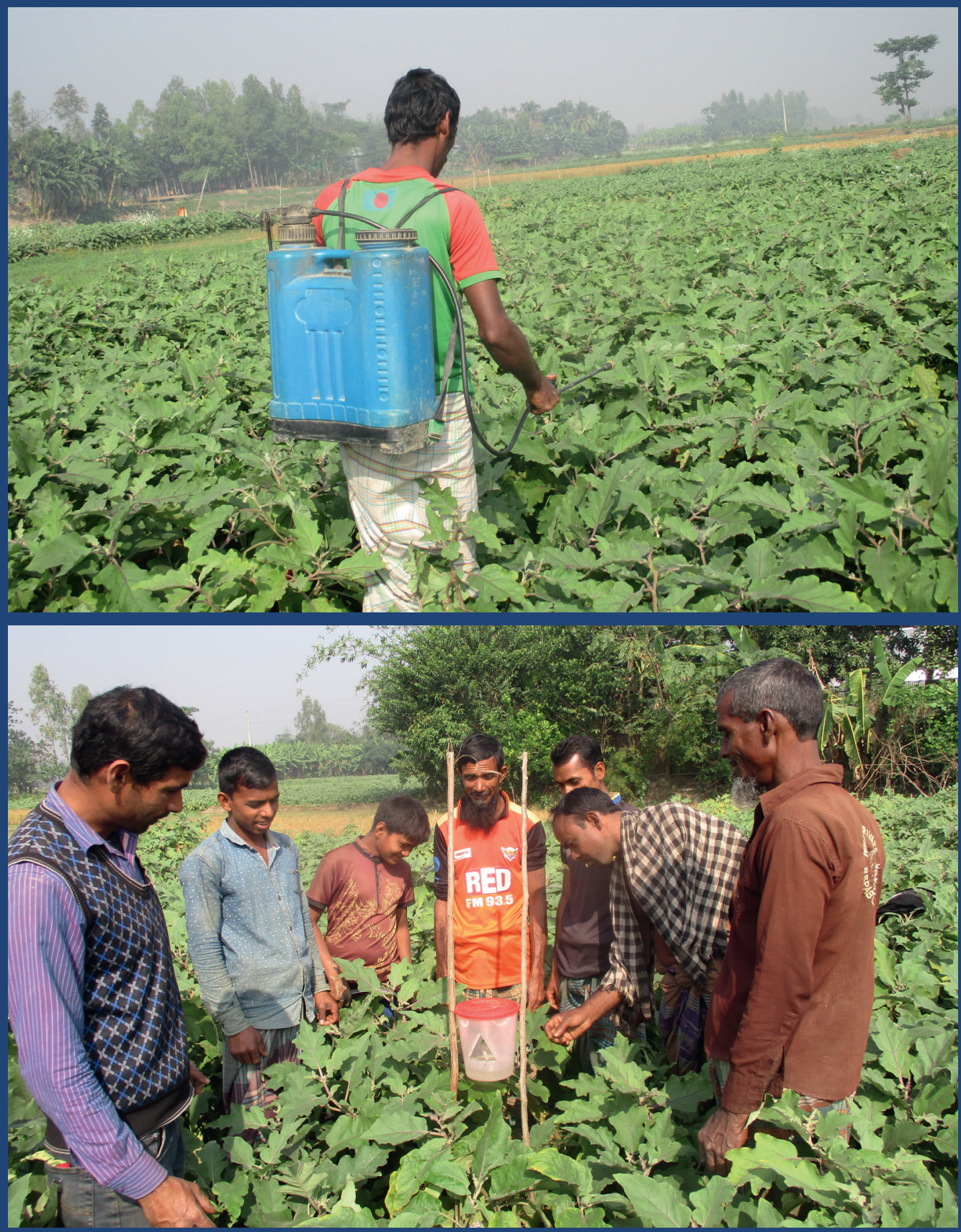





\section{Propositions}

1. Integrated Pest Management must entail control of all organisms relevant to farmers. (this thesis)

2. Integrated Pest Management is Integrated People Management. (this thesis)

3. In research for development, technicality and practicality must go hand in hand.

4. Participatory research with farmers opens a third eye to observe society.

5. Students of an agricultural university must spend a semester in the field with farmers.

6. The title Doctor of Philosophy $(\mathrm{PhD})$ is merely ornamental unless one realizes the philosophy behind it.

Propositions belonging to the $\mathrm{PhD}$ thesis, entitled:

Co-designing Integrated Pest and Disease Management strategies in eggplant production in Bangladesh

Naznin Nahar

Wageningen, 17 September 2020 

Co-designing Integrated Pest and Disease Management strategies in eggplant production in Bangladesh

Naznin Nahar 


\section{Thesis committee}

\section{Promotors}

Prof. Dr P.C. Struik

Professor of Crop Physiology

Wageningen University \& Research

Prof. Dr M. Mahir Uddin

Professor of Entomology

Bangladesh Agricultural University, Mymensingh, Bangladesh

\section{Co-promotors}

Dr T.J. Stomph

Associate professor, Centre for Crop Systems Analysis

Wageningen University \& Research

Dr P.W. de Jong

Lecturer, Laboratory of Entomology

Wageningen University \& Research

\section{Other members}

Prof. Dr K.E. Giller, Wageningen University \& Research

Prof. Dr T.W. Kuyper, Wageningen University \& Research

Dr C.J.M. Almekinders, Wageningen University \& Research

Dr F.J.J.A. Bianchi, Wageningen University \& Research

This research was conducted under the auspices of the C.T. de Wit Graduate School for Production Ecology and Resource Conservation 


\title{
Co-designing Integrated Pest and Disease Management strategies in eggplant production in Bangladesh
}

\author{
Naznin Nahar
}

Thesis

submitted in fulfilment of the requirements for the degree of doctor at Wageningen University

by the authority of the Rector Magnificus

Prof. Dr A.P.J. Mol,

in the presence of the

Thesis Committee appointed by the Academic Board

to be defended in public

on Thursday 17 September 2020

at 11 a.m. in the Aula. 


\section{Naznin Nahar}

Co-designing Integrated Pest and Disease Management Strategies in eggplant production in Bangladesh, 164 pages.

$\mathrm{PhD}$ thesis, Wageningen University, Wageningen, NL (2020)

With references, with summary in English

ISBN: 978-94-6395-478-5

DOI: https://doi.org/10.18174/528043 


\section{Dedicated To}

My mother: Khodeza Khanom

My late father: Joynal Abedin

And

Farmers of Bangladesh 

"It is not my contention that chemical insecticides must never be used. I do contend that we have put poisonous and biologically potent chemicals indiscriminately into the hands of persons largely or wholly ignorant of their potentials for harm. We have subjected enormous numbers of people to contact with these poisons, without their consent and often without their knowledge."

— Rachel Carson, Silent Spring, 1962 



\begin{abstract}
Naznin Nahar (2020). Co-designing Integrated Pest and Disease Management strategies in eggplant production in Bangladesh. $\mathrm{PhD}$ thesis, Wageningen University, Wageningen, The Netherlands, with summary in English, 164 pp.
\end{abstract}

Integrated Pest Management (IPM) was developed in response to the crisis caused by unrestricted use of pesticides. The IPM concept matured over time and today, it stands on a solid conceptual basis and millions of farmers across the globe, especially in developing countries, have been trained in it through the Farmers' Field School approach. Nevertheless, adoption rate remains frustratingly low. This thesis tries to understand why IPM is so difficult to implement for smallholder farmers in developing countries and what is needed to make IPM work for them. Eggplant production in Bangladesh was taken as a case and it involved various disease and insect problems. Involving farmers in the research, this study aimed to craft IPM options for farmers that could function in their context, that maximally use natural enemies and that significantly reduce pesticide use. It also assessed the possible reasons for IPM research failures and possible factors contributing to the success or failure of the crafted IPM.

Farmers participated through interviews, group discussions and field experimentation in tailoring IPM. Negotiations and discussions with these farmers were used to get a better grip on the underlying complexity of all tested IPM options that might hamper adoption. Moreover, a few in vitro and screen house studies were carried out to identify the source of infection of the diseases and to disentangle relative roles of selected IPM components in reducing infections.

For each of the disease and insect problems, farmers' conventional practice of spraying proved ineffective. In contrast, a combination of IPM options proved technically sound and economically viable. However, bottlenecks to scale out these IPM options still remain. For damping-off (caused by several pathogens), soil application of Trichoderma harzianum (T. harzianum) in the nursery combined with seed treatment with hot water was effective, producing 25-64 percentage points more healthy seedlings than farmers' conventional practice of spraying. This combined treatment also improved seedling quality traits. Laboratory and screen house studies confirmed soil as the major source of pathogen and T. harzianum as major player in both reducing damping-off and enhancing seedling growth. Seedlings raised either by improved practice or farmer's practice were also transplanted either with or without soil application of T. harzianum in the production field. Transplanting seedlings from improved practice alone reduced wilt and fruit rot, increased marketable yield and farmers' income compared with their conventional practice of spraying. An additional effect was found when $T$. 
harzianum was applied to the field soil. T. harzianum persisted in the improved management fields at the end of the growing season and reduced wilt and rot pathogens. For the management of the eggplant shoot and fruit borer moth (ESFB), pheromone trapping alone or combined with trap-catch-based biorational insecticide spraying reduced fruit infestation, increased yield and income at costs comparable to farmers' conventional practice. These two IPM options did not affect predatory ladybird beetles and parasitoids Trichogramma spp. and Bracon spp. Farmers' proposed conventional insecticide spraying with pheromone trapping did not provide further control beyond the trapping alone, rather it affected natural enemies. Farmers' practice did not reduce infestation but reduced populations of natural enemies. Therefore, installing trap only or adding biorational insecticide spraying with trapping both can be recommended to farmers. However, farmers lacked knowledge of ESFB biology; they need such knowledge to understand the trapping mechanism and its efficacy. As trapping was tested in a network of nearby fields of these smallholder farmers, there was a shared concern from researcher and farmers whether the use of mass trapping as an individual farmer with a small plot would be effective; traps might attract male moths from surroundings outweighing the local depletion. Indeed trapping in a single field (4 trap) was found ineffective as it showed comparable fruit infestation with farmers' practice field. In contrast, when traps were installed in an array of $4 \times 6: 24$ traps (combination of 3-4 adjacent fields) and in networks of nearby fields (3-5 fields at a distance of 10-25 m), infestation was substantially reduced compared with farmers' standard practice. Per trap, catch of a 4-trap field was three times higher than in 24-trap and network fields; however, infestation in 4-trap field was higher than in 24-trap or network fields, indicating moths were attracted in a 4-trap field from surrounding untrapped fields. For effective trapping, concerted action is needed either by neighbours with directly adjacent fields allowing an array of $4 \times 6$ traps or by farmers of nearby fields.

For each of the participatory studies, farmers desired some chemical treatment with IPM options. Although farmers dropped the chemical treatment after a year of study, still it is questionable whether they will continue with purely IPM options because these farmers are used to spray. Therefore it is better to include spraying with biorationals. Farmers rejected labour-intensive practices. IPM options, generated from this thesis, proved technically and economically viable, but there were some bottlenecks: unavailability of $T$. harzianum, seed treating machine and pheromone lures, a mismatch between farmers' knowledge and use of pheromone trapping, and the need for social organisation for trapping to be effective. To alleviate these obstacles, extension and institutional support are required. 


\section{Table of contents}

Chapter 1 General Introduction 1

Chapter 2 Reducing damping-off problems in eggplant (Solanum melongena 25

L.): a participatory testing of nursery management in Bangladesh

Chapter 3 Disease management in eggplant (Solanum melongena L.) nurseries 53 also reduces wilt and fruit rot in subsequent plantings: A participatory testing in Bangladesh

Chapter 4 Technical efficacy and practicability of mass trapping for insect control in Bangladesh

Chapter 5 Smallholders and pheromone traps: when does an opportunity become a risk?

Chapter 6 General Discussion

Summary

Acknowledgements

List of Publications

PE \& RC training and Education Statement

About the author

Funding 



\section{CHAPTER 1}

General Introduction 


\section{Losses from pests and diseases and their consequence to global agriculture}

The world population is increasing, and it is estimated to reach around 9 billion by 2050 (Carvalho, 2006). Most of this population growth will occur in developing countries. To feed this growing population, 60-70\% more food needs to be produced (Meyers and Kalaitzandonakes, 2015). One of the largest hindrances in worldwide contemporary agricultural production are pests and diseases. Worldwide plant pests and diseases are claimed to cause $30-60 \%$ yield loss depending on the crop (Oerke, 2006). Yield losses from pests and diseases have been estimated to range from 10 to $50 \%$ in South and Southeast Asian countries (Dhaliwal et al., 2010). These losses pose a major threat to income and food security, particularly for smallholders (Dhaliwal et al., 2010).

To assure food security, agricultural production increased worldwide, partly through increasing the cultivated area, partly by producing more on the same land area. The latter was accompanied by increased use of agrochemicals, particularly fertilizer and pesticides. Agricultural intensification and increased use of pesticides go hand in hand (Matson et al., 1997; Pingali and Gerpacio, 1997; Carvalho, 2006). Worldwide, annual use of pesticides has been reported to amount 2 million tonnes (Sharma et al., 2019). Extensive use and even overuse of pesticides occurred in developing countries (Echobichon, 2001; Schreinemachers et al., 2020). This has caused severe ecological, environmental and socioeconomic problems. Especially four problems stand out: development of resistance to pesticides, environmental contamination, high costs of expensive pesticides, and human health hazards (Edwards 1993; Pimentel, 1995; Pingali, 1995; Aktar et al., 2009; Gill and Garg, 2014; Nicolopoulou-Stamati et al., 2016). Moreover, overuse of pesticides kills natural enemies (predators, parasitoids) and other beneficial organisms (Theiling and Croft 1988; Ruberson et al., 1998; Goulson, 2018; Ostiguy et al., 2019). Decimation of natural enemies leads to secondary pest outbreaks and target pest resurgence (Dutcher, 2007). Ironically, despite a clear increase in pesticide use, crop losses have not significantly decreased during the last 40 years (Oerke, 2006). One of the major reasons for this is resistance development by pests and diseases. Ultimately, the reliance on pesticides has produced 'a feedback loop of pesticide use' often termed as the "pesticide treadmill". 


\section{Integrated pest management}

Already 70 years ago, the major drawbacks of the use of pesticides incentivized the conceptualization of integrated pest management (IPM) approaches. The main focus was given during that period on preserving natural enemies by judicious use of pesticides (Ehler, 2006). A decade later, Stern et al. (1959) proposed that integrated pest management should be developed based on an ecological framework in which chemical and biological control act together. The intention was to keep the pest population below economic damage threshold levels. Three years later in 1962, Rachel Carson depicted the consequences of indiscriminate pesticide use in her book "Silent spring" and called for sustainable pest management (Carson, 1962). This book got the attention of the general public and the scientific community. Thereby, the stage was set for change. Since then IPM has been further researched and in the scientific literature is seen as an orchestrated integration of multiple complementary methods to suppress pests in a safe, cost-effective, and environmentally friendly manner (Kogan, 1998; Ehler, 2006; Barzman et al., 2015). With the passage of time, to support IPM development, new tools and strategies (both suppressive and curative) have been developed such as use of semio-chemicals, host plant resistance, cultural control $^{1}$, biological control, and use of selective and biorational ${ }^{2}$ pesticides. The IPM, which was originally proposed as "Integrated control", evolved over time and until today comes with 65 definitions. In the early days of IPM, the definition given by the Food and Agriculture Organization (FAO, 1966) was widely accepted among scientists: "Integrated Pest Control is a pest management system that, in the context of the associated environment and the population dynamics of the pest species, utilizes all suitable techniques and methods in as compatible a manner as possible and maintains the pest population at levels below those causing economic injury". Kogan (1998) synthesized all available definitions and came with five aspects of IPM, which previous authors attempted to capture: i) the appropriate selection of pest control methods either used singly or in combination; ii) economic benefits to growers and society; iii) benefits to the environment; (iv) the decision rules that guide the selection of the control action; and (v) the need to consider impact of multiple pests. According to Kogan (1998) "IPM is a decision support system for the selection and use of pest control tactics, singly or harmoniously coordinated

\footnotetext{
${ }^{1}$ Cultural control is the deliberate alteration of the production system, either the cropping system itself or specific crop production practices, to reduce pest populations or avoid pest injury to crops. For example: crop rotation, sanitation, removal of alternate hosts, early or delayed planting, destruction of refugia of pests and diseases.

${ }^{2}$ Products that are mostly targeting the harmful organisms and are less detrimental to natural enemies and the environment.
} 
into a management strategy, based on cost benefit analyses that take into account the interests of and impacts on producers, society, and the environment". The IPM that has started focussing mainly on insect control, gradually, in definitions, expanded to control of a wider range of pests at a time. Prokopy (2003) emphasized this as "a decision-based process involving coordinated use of multiple tactics for optimizing the control of all classes of pests (insects, pathogens, weeds, vertebrates) in an ecologically and economically sound manner."

Since its inception, the concept and definition of IPM have been refined, redefined and tuned in many ways. Today, IPM stands on a solid conceptual basis. In practice, however, two approaches namely 'tactical IPM' and 'strategic IPM' are mentioned and both are fundamentally different in concept and impact. Tactical IPM is essentially a pesticide-based approach using crude thresholds. In contrast, strategic IPM is based on a detailed knowledge of the agroecosystem, its components and interactions. In other words, strategic IPM has been presented as the ideal and tactical IPM as a relatively weak expression of that ideal (Morse and Buhler, 1997). Due to the complex nature of the strategic IPM, the tactical IPM is often considered as a stepping stone towards the strategic IPM.

However, in the eyes of farmers, IPM, like any other agronomic practice, should contribute to generating sufficient income helping them to sustain their livelihood (Morse, 2009; personal observation). They do not bother about technical excellence, and little about environmental benefit. A large part of the theoretical debate on maintaining ecological services beyond production and income is not their practical concern. In their view, IPM is something they may use if and when they can do it and it will provide them with tangible benefits.

In the end, this consideration from a farmers' perspective implies that IPM as it was originally envisioned in its full strategic form, will probably rarely be implemented. In the debate in the literature whether IPM should be more strategic or more tactical (operational), I would take the stand that striving for a pure strategic IPM while designing an IPM that should work for farmers may not be appropriate and allowing tactical components will be required, while maintaining the aim of reduced environmental damage.

\section{Low adoption of IPM and possible underlying reasons}

Despite the solid conceptual basis as indicated above, huge investment in IPM research and substantial promotion by scientists, environmentalists, and international and national agencies, IPM has a frustratingly low adoption rate particularly in developing countries 
(Barfield and Swisher, 1994; Morse and Buhler, 1997; Ehler and Bottrell, 2000; Bajwa and Kogan, 2003; Orr, 2003; World Bank, 2005; Ehler, 2006; Morse, 2009; Zalucki et al., 2009; Parsa et al., 2014). Although one of the major goals of IPM was to reduce pesticide use, unfortunately, overall use of pesticides has not decreased in most countries, with a few exceptions (see for example Norton and Mullen (1994)). There was no convincing evidence for changes in pesticide use in targeted crops such as rice or cotton in e.g. Asia (Robinson et al., 2007; Narayanan and Viswanathan, 2015). Even in developed countries, reduction of pesticide use was questioned (Ehler, 2006).

The reasons for the overall poor adoption of IPM in developing countries are varied, numerous and complex (Morse and Buhler, 1997; Orr, 2003; Parsa et al., 2014). A survey among practitioners and researchers from across the world by Parsa et al. (2014) identified 51 obstacles for IPM adoption distributed over six categories: poor outreach, weak adoption incentives, weaknesses in proposed IPM, weaknesses in IPM research, pesticide industry interference, and farmer weaknesses. Globally, problems related to outreach, IPM itself and adoption incentive ranked as major. However, for Asia, particularly for South and Southeast Asia, weaknesses in IPM and IPM research, weak adoption incentive and pesticide industry influence were found more dominant (Parsa et al., 2014).

Weaknesses in IPM might include the inherent complexity of IPM (IPM is more difficult to understand and implement compared with conventional spraying), labour-intensiveness, the fact that IPM requires time to have an effect, and the tendency of costs of IPM being much more apparent than its benefits. On the other hand, benefits of pesticides are much more apparent than their negative effects and IPM sometimes requires collective action within farming communities (Parsa et al., 2014). As mentioned earlier, IPM is often difficult to understand; several studies highlighted farmers' knowledge level as a potential constraint to adoption (Litsinger et al., 2009; Peshin, 2013; Wyckhuys et al., 2019). Weaknesses in IPM research have been mentioned to include poor attention to farmers' need (researchers are more inclined to their own logics on what farmers need rather than on the actual needs), lack of interdisciplinarity (instead of 'holistic thinking' researchers are narrowly focussed within disciplines), and insufficient attention to participatory methods (Morse and Buhler, 1997; Parsa et al., 2014). Lack of adoption incentive such as market incentive for farmers and lack of favourable government policies and support can also have contributed to low adoption (Parsa et al., 2014). The powerful influence of the pesticide industry and unrestricted sale of pesticides in rural areas also keeps farmers from applying IPM approaches (Parsa et al., 
2014). Finally, among outreach problems, insufficient training and technical support to farmers, limited access to IPM inputs, shortage of well-qualified experts and extensionists are worth mentioning (Morse and Buhler, 1997; Morse, 2009; Parsa et al., 2014).

High adoption of IPM in developing countries is expected only if the barriers mentioned above can be tackled. However, it is also to be noted that IPM originated in the developed world based on the analysis of agroecosystems and contexts of farmers in that part of the world. Following the same philosophy (more strategic IPM) might not work for farmers in developing countries (Way and van Emden, 2000). For example, in developed countries, crops are grown in large areas (holdings are big), agroecosystems are comparatively simple, markets are stable, farmers are educated, extension services are rich, pesticide governance is strong. In contrast, in developing countries, more specifically in South and Southeast Asia, holdings are fragmented thus crops are grown in small areas, cropping systems are complex (Niroula and Thapa, 2005), markets are variable and seasonal, farmers are less educated, extension services are weak, and pesticides are available everywhere with limited governance (Morse and Buhler, 1997; Shepard et al., 2009; Shammi et al., 2017). When we offer the originally envisioned ideal IPM to farmers of developing countries, smallholders often fail to implement that IPM. Therefore, while developing IPM for developing countries, scientists should consider what is achievable under farmers' conditions rather than what is technically and theoretically perfect (Morse and Buhler, 1997; Morse, 2009). IPM should address needs of farmers and their participation in the development process. It should also use several components that are compatible and not labour-intensive and more profitable than pesticide use (Morse, 2009; Parsa et al., 2014). Moreover, as pests are likely to move between smallholdings, solutions should be found for those elements that require collective action (Parsa et al., 2014). Ultimately, while providing IPM to farmers, their socio-economic context (in other words, labour, input and output markets, income and knowledge level) need to be considered seriously. In brief, to provide a realistic IPM to target farmers, both technical efficacy and practical applicability need to be considered.

In this thesis, eggplant production in the Jamalpur district in Bangladesh is taken as a case to study the development of a more integrated pest management in a developing country and the underlying bottlenecks for use of such an IPM. I therefore continue by describing some relevant developments in the agriculture of Bangladesh. 


\section{Agricultural intensification in Bangladesh}

Bangladesh is a country with 162 million inhabitants with an average population density of 1115 per $\mathrm{km}^{2}$, one of the highest in the world (BBS, 2018). With an ever-increasing population to feed, it is crucial to increase crop production. In Bangladesh, the average farm size has declined over the years. At present, average landholding per household is really small (0.6-0.8 ha) (BBS, 2018). Therefore, area expansion of production seems impossible. Effort has already been taken to increase crop yield per unit area through production of several crops per year on a single plot (Ahmed et al., 2009). In such cropping patterns, high-yielding rice varieties and different vegetables have been included resulting in an average cropping intensity of $190 \%$ for the country. In brief, agriculture of Bangladesh has changed from a primary focus on rice production to a more diversified production including high-value crops, especially vegetables (Rahman, 2009; Schreinemachers et al., 2016). The share of vegetable cultivation area of the total area of arable land has become almost doubled from 1980 to 2002, from 1.9 percent up to 3.6 percent $(\mathrm{ADB}, 2001)$. The area under vegetable production is 470,414 ha with a reported 2.8\% growth rate per year (Mahmoud and Shiveley, 2004; BBS, 2010). This change has not only enhanced agricultural growth of the country but also improved the livelihood of smallholders (e.g. Weinberger and Genova II, 2005). Vegetable production provided at least three times higher income than rice production per unit land area (Shahabuddin and Dorosh, 2002; Weinberger and Lumpkin, 2005, 2007). This has incentivized policymakers to promote vegetable production among smallholders. Consequently, vegetable production in Bangladesh is more market oriented nowadays.

\section{Pesticide use in Bangladesh and its consequences}

Pesticide use in Bangladesh started back in the 1970s when the government started to encourage crop production by providing pesticides to farmers at no cost. This practice continued until 1974 and, afterwards, was changed to providing subsidy of up to $50 \%$ on pesticides (Amin and Basu, 2004). Agricultural intensification caused a sharp rise in pesticide use by a staggering $1340 \%$ from only 3135 metric tons of active ingredients in 1977 to 45,172 metric tons in 2009 (Rahman, 2013). There was a fivefold increase in pesticide use between 1990 and 2010 in Bangladesh (Pretty and Bharucha, 2015). FAO reported that 1\% increase in crop output per ha was associated with a $1.8 \%$ increase in pesticide use. Afterwards, total pesticide use has been reported to have decreased by $26 \%$ until 2014 . However, it is to be noted that this reduction might have happened in other crops but not in vegetables (Rahman, 
2013). Also, due to weak regulation in pesticide marketing, there are many banned products still available in the market and used by farmers (Rahman, 2013; Shammi et al., 2017). Still pesticide use in Bangladesh is six times higher in vegetables than in rice $\left(1.12 \mathrm{~kg} \mathrm{ha}^{-1} \mathrm{vs} 0.20\right.$ $\mathrm{kg} \mathrm{ha}^{-1}$ ) (Alam, 2013). This scenario is true for many Asian countries. For instance, pesticide use in vegetable production in China is around $44 \mathrm{~kg} \mathrm{ha}^{-1}$, which is three times more than the world average of $14 \mathrm{~kg} \mathrm{ha}^{-1}$ (Fan et al., 2015). Around 30\% of the total pesticides were used for vegetable and fruit production in India and Thailand (Jungbluth, 1997; Lanting et al., 1998). It has been reported that the health and environmental costs of pesticide use in vegetables in Thailand is five times higher per hectare compared with rice (Praneetvatakul et al., 2013). In Bangladesh, the yearly increase in pesticide use in vegetables is 1-2\% (Dey, 2010). Around $47 \%$ farmers of Bangladesh were found to have overused pesticides, with an average overuse rate of $3.4 \mathrm{~kg}$ per ha per growing season (Dasgupta et al., 2007). A recent study by Schreinemachers et al. (2020) reported that $60-100 \%$ of the sampled vegetable farmers in Vietnam, Cambodia and Laos overused pesticides. This indicates well that farmers of Southeast Asia spray excessively and inefficiently. This overuse of pesticides definitely increased the cost of production (Schreinemachers et al. 2020). Apart from increasing cost, it has severe effects on non-target organisms including natural enemies and beneficial insects, human health and environment. Health and environmental risks associated with high levels of synthetic pesticide use in Bangladesh have been well-documented (e.g. Dasugpta et al., 2005, 2007; Akter et al., 2018; Sumon et al., 2018; Shammi et al., 2020). Contamination of waterbodies by pesticides is also well-documented (Shammi et al., 2017; Hasanuzzaman et al., 2018). In most of the vegetables including eggplant, pesticides are detected at the level beyond the maximum residue limit (Chowdhury et al., 2013). This led other countries to consider restricting vegetable imports from Bangladesh (Rahman, 2016). Most importantly, health of farmers is at great risk as they do not use any protective gear as reported by Akter et al. (2018).

\section{Integrated Pest Management in Bangladesh}

Also in Bangladesh, the history of IPM is long and one of the main incentives was the reduction of pesticide use. IPM first started in 1981 through FAO's inter-country programme (ICP) targeting the rice crop. Afterwards, in the 1990s, this programme provided extensive training to DAE (Department of Agriculture Extension) and NGO staff and launched Farmers' Field Schools (FFSs) to train farmers. With the technical and financial assistance 
from international organizations like FAO (Food and Agriculture Organization of the United Nations), UNDP (United Nations Development Programme), DANIDA (Danish International Development Agency) and DFID (Department for International Development in the UK), IPM was not confined to rice only but it was extended to vegetables and by 2002, 4,534 FFSs on rice and vegetables had been completed that provided practical training to 113,239 farmers. Consequently, Bangladesh officially formulated a national Integrated Pest Management Plan in 2002 based on mostly strategic IPM principles (MOA, 2002). IPM projects and training continued to expand with the aid of all those above-mentioned international agencies at different phases (Rahman et al., 2009). DANIDA funded a programme called "Strengthening Plant Protection Service (SPPS)" that ended in 2006 and resulted in 212,500 trained farmers through 8,500 FFSs. USAID funded the "IPM Collaborative Research and Support Programme (IPM-CRSP)" that started its first phase in 1998 while the fifth phase is going on as the "IPM-Innovation Lab (IL)" project in collaboration with the Bangladesh Agricultural Research Institute (BARI). DFID funded an eggplant IPM project in which the World Vegetable Center (AVRDC) and BARI (Bangladesh Agricultural Research Institute) collaborated until the beginning of 2006. From the inception of vegetable IPM in the 1990s until today, with the aid of those international and national agencies IPM technologies for several vegetable crops have been developed and promoted by DAE and NGOs. Eventually, government permits registration of biocontrol products from 2010. Until today, DAE has completed more than 20,000 FFSs and trained nearly a million farmers. Despite all those efforts, IPM is poorly adopted by farmers; in reality, IPM does not ripple out in wider communities, as observed across the world (Parsa et al., 2014). From data on pesticide use in vegetables, it is clear that farmers did not adopt IPM technology. Pesticide residues in different vegetables are well-documented (Chowdhury et al., 2013; Hossain et al., 2015). In major vegetable growing areas, for example Jamalpur district of Bangladesh, pesticide residues above the maximum residue level are detected in the aquatic systems (Kizar et al., 2018). From the same area, $80 \%$ of the interviewed farmers mentioned health problems like headache and vomiting because they have to spray frequently (Akter et al., 2018). I hypothesize that the low adoption of IPM has both socio-technical and institutional reasons. Basically, there were huge efforts on IPM promotion but less efforts on developing IPM components or packages that will fit farmers' socio-economic contexts. Practicability of IPM is often not considered; for example, whether the IPM matches with farmers' knowledge, labour availability, and economic investment capacity has not been considered. 


\section{The Farmers' Field School approach}

To promote IPM, the Farmers' Field School (FFS) approach originated in Asia under the umbrella of the "FAO-IPM in Asia Programme". It was first started with rice farmers in Indonesia in 1989. The main goal of this approach was to train farmers on agroecosystem analysis so that they could take their own pest management decisions. Typically, 25 farmers are selected for a FFS and trainers and farmers interact once a week throughout the cropping season. It stresses the importance of farmers growing a healthy crop, observing their fields weekly, conserving natural enemies, and experimenting themselves using relevant IPM components (Tripp et al., 2005). The FFS approach was later implemented in 12 other Asian countries. Later, to implement IPM, this approach crossed the boundaries of Asia and spread to Africa, Latin America, the Caribbean and Eastern Europe and in some cases to Australia and North America (Braun et al., 2006; Van den Berg and Jiggins, 2007). Gradually, the FFS approach shifted from rice to vegetables and other crops. FFS programmes are being implemented in 78 countries and four million farmers have been trained under such programmes, 91\% of these from South and Southeast Asian countries including Bangladesh (Braun et al., 2006). Much success has been claimed for this approach, for example, yield increase, reduction in pesticide use and huge adoption of IPM (Prudent et al., 2006; van den Berg and Jiggins, 2007; Pretty and Bharucha, 2015). However, results of impact evaluation conducted by FAO and World Bank contradicted those claims of success. A World Bank study conducted by Feder et al. (2004) indicated that the IPM-FFS programme in Indonesia did not have significant impact on the trained farmers and their neighbours; trained farmers neither increased yield nor reduced pesticide use significantly compared to untrained farmers.

Despite a significant effort to develop IPM packages for vegetables and training of farmers by FFS, IPM is poorly adopted. Therefore, a research programme was required to investigate causes of low adoption and how IPM can be made more adoptable for farmers. This research programme will be described in the following sections.

\section{Project background}

This thesis research is part of the NUFFIC-NICHE-BGD-156 programme in which Wageningen University and Research Centre (WUR) and Bangladesh Agricultural University (BAU) collaborate. The programme purposively selected areas of Bangladesh prone to disaster. $\mathrm{PhD}$ students conducted focus group discussions (FGD) with farmers and other stakeholders (GO and NGO personnel) in Jamalpur district, Bangladesh in September, 2013. 
Amongst others, farmers designated pest control in eggplant (Solanum melongena L.) as problematic. They indicated they felt the need to spray a variety of chemicals at least three times per week and even daily during the peak growing season. More spraying seemed necessary than a few years back. Moreover, farmers observed health hazards, water pollution and disappearance of some spiders and beetles.

Eggplant is one of the most important vegetable crops of South and Southeast Asian countries including Bangladesh because of its high consumption and economic value to farmers. In 2015-2016, an area of 50,000 ha was cropped with eggplant corresponding to nearly $10 \%$ of the area under vegetables (BBS, 2017). Eggplants are mainly cultivated by smallholders. As eggplant can be harvested and sold weekly for 4-6 months (prolonged fruiting period), it plays a pivotal role in the livelihood of small landholders. While eggplant production is very profitable, its sustainability is at risk. This thesis will therefore focus on identifying, designing and testing more sustainable pest management options in eggplant production through a participatory research approach.

\section{Constraints in eggplant cultivation and current pest management practice}

One of the major impediments of eggplant cultivation is the eggplant shoot and fruit borer moth (ESFB): Leucinodes orbonalis Guenée (Lepidoptera: Pyralidae) (Alam et al., 2006; Srinivasan, 2008). During the early vegetative stage, caterpillars of this moth penetrate shoot apices, causing these to drop off thus impeding plant growth. During the fruiting stage, caterpillars mostly infest fruits. Caterpillars tunnel inside the fruit and fill it with excreta, the latter enhancing secondary infection, and making the fruit usually unfit for sale and consumption (Srinivasan, 2008). Yield losses of 30 to 90 percent have been reported (Srinivasan, 2008).

The vast majority of farmers in Jamalpur and the rest of Bangladesh rely exclusively on chemical insecticides to combat ESFB. Farmers spray a variety of broad-spectrum insecticides once per week to daily in the 6-month growing season (Mohiuddin et al., 2009; Shelton et al., 2018), investing $30-50$ percent of input costs in insect control (Alam et al., 2006). Such an insecticide-dependent strategy poses both environmental and health concerns. Consumers are concerned about the safety of the food they eat as studies regularly find pesticide residues above acceptable levels (Chowdhury et al., 2103; Hossain et al., 2015). Therefore, eggplant growers need environmentally-benign and cost-effective alternatives to 
the currently used broad-spectrum insecticides. A change to more integrated pest management would be desirable. For that a full understanding of the insects' life cycle is required.

\section{Biology of eggplant shoot and fruit borer}

The adult females lay eggs singly or in batches of two to five on the ventral surfaces of leaves, tender shoots, flower buds, or calyces of developing fruits. Each female lays about 260 eggs, which are creamy-white soon after laying, but changed to red before hatching. The incubation period is three to five days. After hatching, caterpillars bore into the shoots at the vegetative stage of the plant; however, at fruiting stage of the plant caterpillars limit infestation mostly to fruits. Caterpillars feed inside shoots and fruits by making tunnels. The larva usually has five instars. The larval period is about 2-3 weeks. Caterpillars then leave the shoots or fruits to pupate on plant debris on the soil surface or in the soil. The pupation occurs in tough silken cocoons. After one to two weeks of pupation, moths emerge, making the total life cycle duration between 20 and 45 days depending on temperature. It gives rise to five generations a year. The adult life span is about a week; the females live longer than the males. The moth is white or dirty white with pale brown or black spots on the dorsum of thorax and abdomen. The female is bigger than the male, with a bulged abdomen (Srinivasan, 2009; Mainali et al., 2014; Mannan et al., 2015).

\section{Solutions offered so far to farmers for managing the eggplant shoot and fruit borer}

More than a decade ago the Asian Vegetable Research and Development Center developed and promoted an eggplant IPM strategy for ESFB control for South Asia including Bangladesh (Alam et al., 2006). This package, based on sanitation, regular removal of infested shoots and fruits, refraining from the use of pesticides and installing pheromone traps was successfully tested in pilot project studies on farmers' fields in five districts in India and four districts in Bangladesh (Alam et al., 2006). Despite having this IPM strategy, farmers continue to use pesticides and adoption remains low. The exact reasons for current low adoption levels are hypothesised to be both technical and socio-institutional. However, one of the main reasons might be the strictly strategic nature of this IPM, in other words, no use of pesticides where farmers are habituated with using it. A further likely factor for poor adoption is that much effort merely considers a single major pest in an IPM strategy rather than all pests farmers would like to control (Horne et al., 2008). Finally, neglecting farmers' needs, 
not involving them in the research and providing them with predefined recipes of IPM is another likely reason for IPM not to succeed (Morse and Buhler, 1997).

The success of an IPM programme depends on both technical efficacy of the recommended IPM options and their compatibility with the target farmers' ecological and socioeconomic conditions (Maumbe et al., 2003). In brief, for pest management options to be adoptable, they have to be ecologically and environmentally sound and socially justifiable (Fernando et al., 2009). In that sense, a tailored or crafted IPM is more likely to be successful than a predefined IPM.

\section{Objective of the thesis}

Based on the above background, the proposed study addresses as central research question:

"What characteristics should an eggplant IPM package have to fit in current farming systems in Jamalpur, Bangladesh?" The main objective of this research is to contribute to the design of an IPM package with stakeholders that will be suited for farmers, maximally uses natural enemies and significantly reduces pesticide use. To this aim a diagnosis was made of reasons for poor IPM adoption through social investigation and biological experimentation followed by, largely participatory, experimentation to identify relevant components of IPM in the given farming system context.

This thesis made an attempt to craft together with farmers options for IPM that could function within their institutional and environmental conditions. Hence, problems regarding IPM and IPM research in relation to the actual complex of major pests and diseases in a concrete cropping system formed the core of the study, focussing on how IPM can be made adoptable. I used a transdisciplinary approach, where on the one hand, interacting with farmers and trying to incorporate their knowledge and suggestions, I identified underlying complexities of previous and proposed IPM. On the other hand, biological experimentation, in which the farmers themselves were fully involved, allowed to identify key elements about which knowledge is required. This also allowed to provide such knowledge to facilitate the implementation of an IPM approach in this key source for sustainable livelihood in Bangladesh. Both the farmers and myself could thereby assess the technical performance of tested packages for ESFB management, including effects on other pests and natural enemies, and separately analyse economic viability. In addition, it allowed me to analyse practical applicability, taking implementation aspects as possible underlying reasons and rationales for farmers to reject, adopt, or adapt them. While the study started with the ESFB as focal 
organism it was allowed to shift attention to other relevant pests and diseases along the negotiations and experimentation.

\section{Study area}

Jamalpur is located in the newly declared Mymensingh Division of Bangladesh. It is located between $24^{\circ} 34^{\prime}$ and $25^{\circ} 26^{\prime}$ North and between $89^{\circ} 40^{\prime}$ and $90^{\circ} 12^{\prime}$ East. It occupies $2031.98 \mathrm{~km}^{2}$. The Brahmaputra river flows alongside the district. One of the major crops cultivated is eggplant. In terms of acreage, Jamalpur ranked top in eggplant cultivation in Bangladesh. Farmers cultivate eggplant in the cool dry season (Rabi: September-March) in the vast area of the river basin. Eggplant farmers in Jamalpur are market oriented and produce for a reasonably stable market. All the studies in this thesis were conducted in Pirijpur village $\left(25^{\circ} 02^{\prime} 13^{\prime \prime} \mathrm{N}-89^{\circ} 50^{\prime} 08^{\prime \prime} \mathrm{E}\right)$ of Islampur upazilla ${ }^{3}$ (dominant eggplant producing area) of the district.

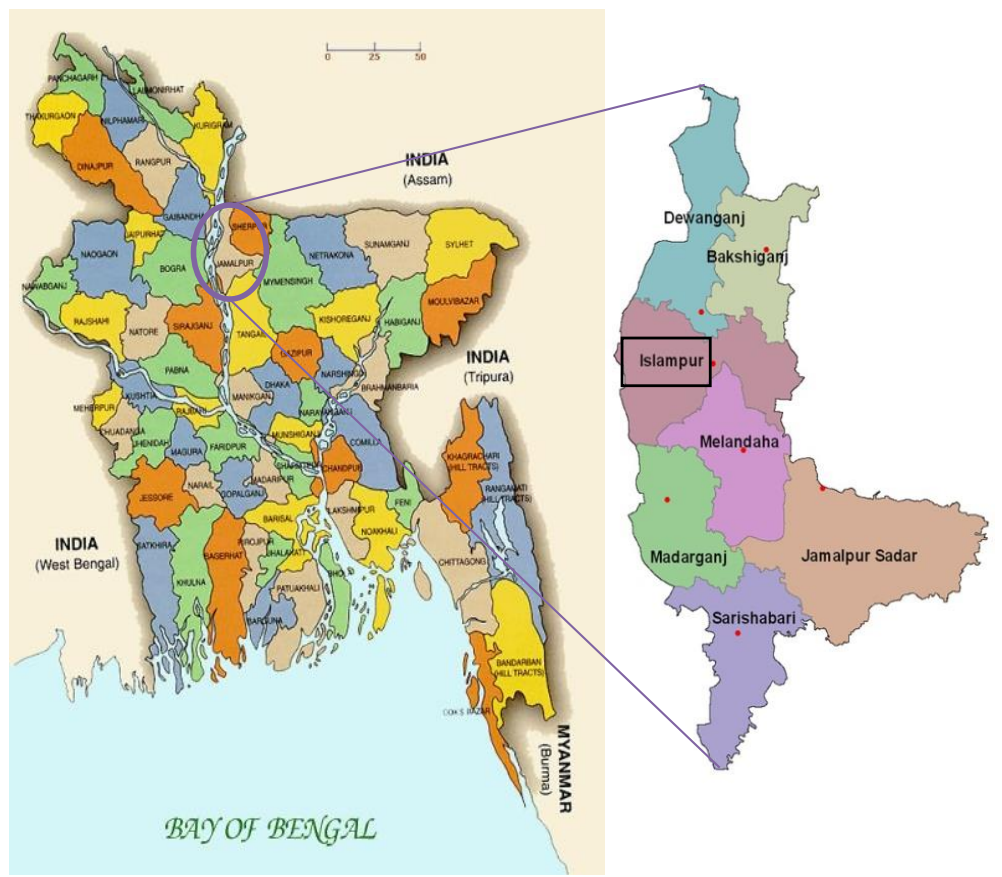

Fig. 1. Map of Bangladesh indicating study area Jamalpur district, the scale indicates distance in miles.

\footnotetext{
${ }^{3}$ the third administrative unit in Bangladesh after division and district.
} 


\section{The process of problem identification}

The current study used a farmers' participatory and collaborative approach. Farmers participated through interviews, group discussions and field experimentation in tailoring IPM. Based on literature and from my entomological background, I initially decided to research on ESFB. To enter the research, I had focus group discussions with farmers and other stakeholders (persons from governmental and non-governmental organisations and scientists from the regional agricultural research station). I learned ESFB is a major problem constraining eggplant production. To start the field research, I first discussed with district and upazilla level agriculture officers and extension staff, and researchers from the regional agricultural research station. I gained an insight into current constraints of eggplant cultivation and also gained an idea of selecting village and farmers. Initially, I made visits to five villages of three upazillas and in each village I did a transect walk, visited farmers' fields and held both formal and informal discussions with them. From this, I came to learn, apart from ESFB, there was another problem that farmers consider controlling urgently and that is bacterial wilt (Ralstonia solanacearum). Farmers also considered fruit rot (Phomopsis vexans) an important production constraint. Apart from these two diseases prevalent in the production field, damping-off in their nursery was a serious problem as it constrained to produce sufficient seedlings to transplant. Farmers mentioned when they transplant the seedlings that survived the damping-off in the nursery, many plants died in the field before fruiting. Hence, in consultation with researchers and the literature I considered that bacterial wilt, fruit rot and damping-off may be partly related problems (Panwar et al., 1970; Ramesh, 2008; Sharma and Razdan, 2012; Sharma and Sharma, 2014). Eventually, I learned that without considering all those disease problems, researching only ESFB would have little value to farmers. Therefore, finally I chose Pirijpur as study village (based on acreage of eggplant and transportation) and I chose farmers (or may be the farmers chose me) based on their enthusiasm to participate in the study. Based on the interactions I conducted participatory studies with these farmers related to the first three of the following specific objectives, while the fourth was studied as researcher managed trials in farmers' fields:

(i) To investigate a feasible disease management option for farmers' nursery problems with damping-off (Chapter 2);

(ii) To investigate the causes of the bacterial wilt and fruit rot and their management options (Chapter 3); 
(iii) To explore the effectiveness, profitability and practicability of alternative ESFB control measures to the sole reliance on broad spectrum synthetic pesticides (Chapter 4);

(iv) To explore suitability of pheromone trapping for individual smallholder farmers versus trapping with a network of farmers (Chapter 5).

Next to these objectives related to designing technically sound and economically viable IPM options for relevant pest and disease problems, the study also investigated the possible reasons for IPM research failures and bottlenecks to adoption of designed packages.

\section{Thesis outline}

This thesis consists of six chapters: this general introduction (Chapter 1), four research chapters (Chapters 2 to 5) and a general discussion (Chapter 6).

In Chapter 1, the introductory chapter, I have given a background on IPM in general and causes of low adoption of IPM especially in developing countries, the history of IPM in Bangladesh, present pest management practices of eggplants and possible reasons of previous IPM failure. In this chapter, I have also introduced the research problem and objectives of the thesis.

In Chapter 2, improved nursery management options were tested together with farmers to manage damping-off as an alternative to pesticide spraying in farmers' homestead nurseries. Based on literature and upon treatment negotiation with farmers, soil application with $T$. harzianum, physical seed treatment with hot water and farmers proposed chemical seed treatment with Carbendazim were tested in a two-year participatory study. This study generated several feasible options for farmers. Apart from the joint study in the nursery, in vitro and screen house tests were performed without farmer participation to understand the relative role of seed and soil in causing damping-off as well as the relative contribution of the treatment components. This provided a better basis to contribute to the discussions with the farmers.

In Chapter 3, an ecologically and economically acceptable wilt management method was developed with farmers. Following the results of the nursery study, healthy seedlings from improved nursery practices were tested together with farmers to reduce wilt and fruit rot. Seedlings were planted alone or with soil application of $T$. harzianum in the field soil. Sources of infection were explored by in vitro and molecular testing. In vitro tests and screen house tests were done to test carry-over of the pathogen in next year's seed and soil. It turned 
out that sustainable production of eggplant is technically and economically feasible with the use of IPM methods, which could be potential components of healthy eggplant production in Bangladesh.

Chapter 4 deals with the eggplant shoot and fruit borer which was the entry point of the research. To find a feasible option for farmers, participatory tests were done after treatment negotiation. Apart from technical efficacy of the tested IPM, economic viability and practical implementation aspects were explored. In this chapter, pheromone trapping alone or with trap-based-biorational spraying or conventional insecticide spraying were tested and compared with farmers' conventional regular spraying and an untreated control. Trapping alone or with biorational spraying was found economically and technically viable; however, from practical implication perspective one major bottle neck was understood: farmers' lack of understanding of insect biology. Farmers can be expected to use tested IPM only when materials are available and with proper training on their knowledge on insect biology and mechanism of trapping.

In Chapter 5, I studied whether local depletion of male moths can outweigh local attraction when traps are implemented in smallholder fields. Based on the observed population biology this chapter gives an indication of how farmers should organize themselves in the landscape to have better benefit from trapping. A concerted action among farmers would be needed.

Finally, in Chapter 6, I integrate findings from Chapters 2, 3, 4 and 5 and discuss the basket of options that is generated with these studies. I discuss underlying bottlenecks of each of the tested IPM tools and ways of mitigating them. Finally, I point out several recommendations to be considered while developing adoptable IPM for smallholder formers in developing countries. Also, some recommendations are made on possible strategies for improving the extension system of Bangladesh to support IPM adoption.

I hope my thesis provides the readers with new knowledge and insights, and that it will contribute to improving the livelihoods of smallholder vegetable farmers, increasing the sustainability of eggplant cultivation and will be used as an example how an IPM could be designed with and for farmers in developing countries. 


\section{References}

ADB (Asian Development Bank)., 2001. Rural development priorities for poverty reduction in Bangladesh. Dhaka, Bangladesh Resident Mission, 51.

Ahmed, A., Doe, D., Sharma, O. P., Kumar, K. C. G., Talpur, S., Piyasena, K., 2009. Status of integrated pest management (IPM) in SAARC countries. SAARC Agriculture Centre, Dhaka.

Aktar, W., Sengupta, D., Chowdhury, A., 2009. Impact of pesticides use in agriculture: their benefits and hazards. Interdisciplinary toxicology, 2: 1-12.

Akter, M., Fan, L., Rahman, M. M., Geissen, V., Ritsema, C. J., 2018. Vegetable farmers' behaviour and knowledge related to pesticide use and related health problems: A case study from Bangladesh. Journal of Cleaner Production, 200: 122-133.

Alam, S. N, Hossain, M. I., Rouf, F. M. A., Jhala, R. C., Patel, M. G., Rath, L. K., Sengupta, A., Baral, K., Shylesha, A. N., Satpathy, S., Shivalingaswamy, T. M., Cork, A., Talekar, N. S., 2006. Implementation and promotion of an IPM strategy for control of eggplant fruit and shoot borer in South Asia. Technical Bulletin No. 36. AVRDC Publication number 06-672. AVRDC The World Vegetable Center, Shanhua, 520 Taiwan. 74 pp.

Alam, S. N., 2013. Extent and Potential Use of Bio-Pesticides for Crop Protection in Bangladesh: Country Status Paper. Division of Entomology, Bangladesh Agricultural Research Institute, Gazipur, Bangladesh.

Amin, S. and Basu, A. M., 2004. Popular perceptions of emerging influences on mortality and longevity in Bangladesh and West Bengal. Population Studies, 58: 357-363.

Bajwa, W. I. and Kogan, M., 2003. Integrated pest management adoption by the global community. In: Maredia, K. M., Dakouo, D., Mota-Sanchez, D (Eds.), Integrated pest management in the global arena. CABI Publishing, USA, pp. 97-107.

Barfield, C. and Swisher, M. E., 1994. Integrated pest management: ready for export? Historical context and internationalization of IPM. Food Reviews International, 10: 215-267.

Barzman, M., Bàrberi, P., Birch, A. N .E., Boonekamp, P., Dachbrodt-Saaydeh, S., Graf, B., Hommel, B., Jensen, J. E., Kiss, J., Kudsk, P., Lamichhane, J.R., 2015. Eight principles of integrated pest management. Agronomy for sustainable development, 35: 1199-1215.

BBS (2010). Bangladesh Bureau of Statistics. Statistical Yearbook of Bangladesh. Dhaka, Bangladesh.

BBS (2017). Bangladesh Bureau of Statistics. Statistical Yearbook of Bangladesh. Dhaka, Bangladesh.

BBS (2018). Bangladesh Bureau of Statistics. Statistical Yearbook of Bangladesh. Dhaka, Bangladesh

Braun, A., Jiggins, J., Röling, N., van den Berg, H. and Snijders, P., 2006. A global survey and review of farmer field school experiences. A report for the International Livestock Research Institute, Wageningen, The Netherlands.

Carson, R., 1962. Silent Spring. Houghton Mifflin Harcourt, USA. 400 pp. 
Carvalho, F. P., 2006. Agriculture, pesticides, food security and food safety. Environmental Science Policy, 9: 685-692.

Chowdhury, M. A. Z., Fakhruddin, A. N. M., Islam, M. N., Moniruzzaman, M., Gan, S. H., Alam, M. K., 2013. Detection of the residues of nineteen pesticides in fresh vegetable samples using gas chromatography-mass spectrometry. Food Control, 34: 457-465.

Dasgupta, S., Meisner, C., Huq, M., 2005. Health effects and pesticide perception as determinants of pesticide use: evidence from Bangladesh. The World Bank.

Dasgupta, S., Meisner, C., Huq, M., 2007. A pinch or a pint? Evidence of pesticide overuse in Bangladesh. Journal of Agricultural Economics, 58: 91-114.

Dey, N. C., 2010. Use of pesticides in vegetable farms and its impact on health of farmers and environment. Environmental Science and Technology, 11: 134-40.

Dhaliwal, G. S., Jindal, V., Dhawan, A. K., 2010. Insect pest problems and crop losses: changing trends. Indian Journal of Ecology, 37: 1-7.

Dutcher, J. D., 2007. A review of Resurgence and Replacement Causing Pest Outbreaks in IPM. In: Ciancio, A., Mukerji, K.G. (Eds.), General Concepts in Integrated Pest and Disease Management. Springer, Dordrecht, pp. 27-43.

Ecobichon, D. J., 2001. Pesticide use in developing countries. Toxicology, 160: 27-33.

Edwards, C. A., 1993. The Impact of Pesticides on the Environment. In: Pimentel, D., Lehman, H. (Eds.), The Pesticide Question. Springer, Boston, MA, pp. 13-46.

Ehler, L. E., 2006. Integrated Pest Management (IPM): Definition, historical development and implementation, and the other IPM. Pest Management Science. 62: 787-789.

Ehler, L. E. and Bottrell, D. G., 2000. The illusion of integrated pest management. Issues in Science andTechnology. 16: 61-64.

Fan, L., Niu, H., Yang, X., Qin, W., Bento, C. P. M., Ritsema, C. J., Geissen, V., 2015. Factors affecting farmers' behaviour in pesticide use: insights from a field study in northern China. Science of the Total Environment. 537: 360-368.

FAO (Food and Agriculture Organization of the United Nations). 1966, Proceedings of the FAO Symposium on Integrated Pest Control, 11-15 October 1965, FAO, Rome, Italy. Part 1, 2, and Part 3. FAO, Rome, Italy.

Feder, G., Murgai, R., Quizon, J., 2004. Sending farmers back to school: The impact of farmer field schools in Indonesia. Review of Agricultural Economics, 26: 45-62.

Fernando, W. D., Ramarathnam, R., Nakkeeran, S., 2009. Advances in Crop Protection Practices for the Environmental Sustainability of Cropping Systems. In: Peshin, R., Dhawan, A. K. (Eds.), Integrated Pest Management: Innovation-Development Process. Springer, Dordrecht, pp. 131162. 
Gill, H. K. and Garg, H., 2014. Pesticide: Environmental Impacts and Management Strategies. In: M. L. Larramendy, M. L., Soloneski, S. (Eds.), Pesticides-Toxic aspects. Intech: Rijeka, Croatia, pp. 187-230.

Goulson, D., Thomson, J., Croombs, A., 2018. Rapid rise in toxic load for bees revealed by analysis of pesticide use in Great Britain. PeerJ, 6: 5255.

Hasanuzzaman, M., Rahman, M. A., Islam, M. S., Salam, M. A., Nabi, M. R., 2018. Pesticide residues analysis in water samples of Nagarpur and Saturia Upazila, Bangladesh. Applied Water Science, 8: 8 .

Horne, P. A., Page, J., Nicholson, C., 2008. When will integrated pest management strategies be adopted? Example of the development and implementation of integrated pest management strategies in cropping systems in Victoria. Australian Journal of Experimental Agriculture, 48: 1601-1607.

Hossain, M. S., Fakhruddin, A. N. M., Chowdhury, M. A. Z., Rahman, M. A., Alam, M. K., 2015. Health risk assessment of selected pesticide residues in locally produced vegetables of Bangladesh. International Food Research Journal, 22: 110-115.

Jungbluth, F., 1997. Analysis of crop protection policy in Thailand. TDRI Quarterly Review. 12: 1623.

Kogan, M. 1998. Integrated pest management: Historical perspectives and contemporary developments. Annual Review of Entomology, 43: 243-270.

Lanting, M., Suresh, C., Chinnakonda, D., 1998. Marketing organic vegetables. Institute for Low External Input Agriculture (ILEIA) Newsletter, p. 24.

Litsinger, J. A., Libetario, E. M., Canapi, B. L., 2009. Eliciting Farmer Knowledge, Attitudes, and Practices in the Development of Integrated Pest Management Programs for Rice in Asia. In: Peshin, R., Dhawan, A. K. (Eds.), Integrated Pest Management: Dissemination and Impact. Springer, Dordrecht, pp. 119-273.

Mahmoud, C. and Shively, G., 2004. Agricultural diversification and integrated pest management in Bangladesh. Agricultural Economics, 30: 187-194.

Mainali, R. P., 2014. Biology and management of eggplant fruit and shoot borer, Leucinodes orbonalis Guenée (Lepidoptera: Pyralidae). International Journal of Applied Sciences and Biotechnology, 2: 18-28.

Mannan, M. A., Islam, K. S., Jahan, M., Tarannum, N., 2015. Some biological parameters of brinjal shoot and fruit borer, Leucinodes orbonalis Guenée (Lepidoptera: Pyralidae) on potato in laboratory condition. Bangladesh Journal of Agricultural Research, 40: 381-390.

Matson, P. A., Parton, W. J., Power, A. G. and Swift, M. J., 1997. Agricultural intensification and ecosystem properties. Science, 277: 504-509.

Maumbe, B., Bernstein, R. Norton, G., 2003. Social and Economic Considerations in the Design and Implementation of Integrated Pest Management in Developing Countries. In: Maredia, K., 
Dakouo, D., Mota-Sanchez, D. (Eds.), Integrated Pest Management in the Global Arena. CABI Publishing, pp. 87-95.

Meyers, W. H. and Kalaitzandonakes, N., 2015. World population, food growth, and food security challenges. Food Security in an Uncertain World (Frontiers of Economics and Globalization, Vol. 15), Emerald Group Publishing Limited, Bingley, pp.161-177.

MOA, 2002. National Integrated Pest Management Policy. Ministry of Agriculture (MOA), Government of the People's Republic of Bangladesh.

Mohiuddin, M., Hossain, M. M., Rahman, A. K. M. M., Palash, M.S., 2009. Socio-economic study of insecticide use on vegetable cultivation at farm level in Chittagong region. Journal of the Bangladesh Agricultural University, 7: 343-350.

Morse, S. 2009. IPM, Ideals and Realities in Developing Countries. In: Radcliffe E. B., Hutchison, D., Cancelado, R. E. (Eds.), Integrated Pest Management: Concepts, Tactics, Strategies and Case Studies. Cambridge university press, pp. 458-470.

Morse, S. and Buhler, W., 1997. IPM in developing countries: the danger of an ideal. Integrated Pest Management Reviews, 2: 175-185.

Narayanan, L. and Viswanathan, P. K., 2015. Technology Diffusion and Adoption in Cotton Cultivation: Emerging Scenario in Gujarat. AgBioforum, 18:209-220.

Nicolopoulou-Stamati, P., Maipas, S., Kotampasi, C., Stamatis, P., Hens, L., 2016. Chemical pesticides and human health: the urgent need for a new concept in agriculture. Frontiers in Public Health, 4: 148.

Niroula, G.S. and Thapa, G.B., 2005. Impacts and causes of land fragmentation, and lessons learned from land consolidation in South Asia. Land use policy, 22(4), pp.358-372.

Norton, G. W. and Mullen, J. 1994. Economic evaluation of integrated pest management programs: a literature review. Virginia Cooperative Extension.

Oerke, E.C. (2006) Global losses to pests. Journal of Agricultural Science, 144: 31-43.

Orr, A., 2003. Integrated pest management for resource-poor African farmers: Is the emperor naked? World development, 31: 831-845.

Ostiguy, N., Drummond, F. A., Aronstein, K., Eitzer, B., Ellis, J. D., Spivak, M., Sheppard, W. S., 2019. Honey bee exposure to pesticides: A four-year nationwide study. Insects, 10: 13.

Panwar, N. S., Chand, J. N., Singh, H., Paracer, S., 1970. Phomopsis fruit rot of brinjal (Solanum melongena L.) in Punjab. Variability of fungus and role of seed in disease development. Ludhiana Journal of Agriculture, 7: 641-643.

Parsa, S., Morse, S., Bonifacio, A., Chancellor, T. C. B., Condori, B., Crespo-perez, v., Hobbs, S. L. A., Kroschel, J., Ba, M. N., Rebaudo, F., Sherwood, S. G., Vanek, S. J., Faye, E., Herrera, A. and Dangles, O., 2014. Obstacles to integrated pest management adoption in developing countries. Proceedings of the National Academy of Sciences, 111: 3889-3894. 
Peshin, R., 2013. Farmers' adoptability of integrated pest management of cotton revealed by a new methodology. Agronomy for Sustainable Development, 33: 563-572.

Pimentel, D., 1995. Amounts of pesticides reaching target pests: environmental impacts and ethics. Journal of Agricultural and Environmental Ethics, 8: 17-29.

Pingali, P. L., 1995. Impact of Pesticides on Farmer Health and the Rice Environment: An overview of Results from a Multidisciplinary Study in the Philippines. In: Pingali, P. L., Roger, P., (Eds.), Impact of Pesticides on Farmer Health and the Rice Environment. Boston: Kluwer Academic Publishers, pp. 3-22.

Pingali, P. L. and Gerpacio, R. V., 1997. Living with reduced insecticide use for tropical rice in Asia. Food Policy, 22: 107-118.

Praneetvatakul, S., Schreinemachers, P., Pananurak, P., Tipraqsa, P., 2013. Pesticides, external costs and policy options for Thai agriculture. Environmental Science and Policy, 27: 103-113.

Pretty, J. and Bharucha, Z. P., 2015. Integrated pest management for sustainable intensification of agriculture in Asia and Africa. Insects, 6: 152-182.

Prokopy, R. J., 2003.Two decades of bottom-up, ecologically based pest management in a small commercial apple orchard in Massachusetts. Agriculture, Ecosystems and Environment, 94: 299-309.

Prudent, P., Loko, S., Vaissayre, M., 2006. Farmers Field Schools in Benin: A participatory approach to the transmission of information on integrated cotton pest management. Cahiers Agricultures, 15: 100-101.

Rahman, M.A., Omar, D., Ullah, M. H., 2009. Developmental perspective of organic farming and IPM: A review of Bangladesh. Proceedings of the 1st International conference on Technology Education and Environment. African Society for Scientific Research.

Rahman, S., 2009. Whether crop diversification is a desired strategy for agricultural growth in Bangladesh? Food Policy, 34: 340-349.

Rahman, S. 2013. Pesticide consumption and productivity and the potential of IPM in Bangladesh. Science of the Total Environment, 445-446:48-56.

Rahman, Z., 2016. Lack of regulations affect vegetable export. The Financial Express. Published 26 March, 2016. http://www.thefinancialexpress-bd.com/2016/ 03/26/23070/asia/print. Accessed 07.08.2017.

Ramesh, R., 2008. Bacterial wilt in brinjal and its management. Technical Bulletin No: 10, ICAR, India. pp. 1-3. Research Complex for Goa (Indian Council of Agricultural Research), Ela, Old Goa- 403 402, Goa, India.

Robinson, E. J .Z., Das, S. R., Chancellor, T. B. C. 2007. Motivations behind farmers' pesticide use in Bangladesh rice farming. Agriculture and Human Values, 24: 323-332.

Ruberson, J., Nemoto, H., Hirose, Y., 1998. Pesticides and conservation of natural enemies in pest management. In: Barbosa, P. (Eds.), Conservation Biological Control. Academic Press, pp. 207-220. 
Schreinemachers, P., Wu, M. H., Uddin, M. N., Ahmad, S., Hanson, P., 2016. Farmer training in offseason vegetables: Effects on income and pesticide use in Bangladesh. Food Policy, 61:132140.

Schreinemachers, P., Grovermann, C., Praneetvatakul, S., Heng, P., Nguyen, T. T. L., Buntong, B., Le, N. T. , Pinn, T., 2020. How much is too much? Quantifying pesticide overuse in vegetable production in Southeast Asia. Journal of Cleaner Production, 244: 118738.

Shahabuddin, Q. and Dorosh, P., 2002. Comparative advantage in Bangladesh Crop Production. MSSD Discussion Paper No. 47. International Food Policy Research Institute, Washington D.C.

Shammi, M., Hasan, N., Rahman, M. M., Begum, K., Sikder, M. T., Bhuiyan, M. H., Uddin, M. K., 2017. Sustainable pesticide governance in Bangladesh: socio-economic and legal status interlinking environment, occupational health and food safety. Environment Systems and Decisions, 37: 243-260.

Shammi, M., Sultana, A., Hasan, N., Rahman, M. M., Islam, M. S., Bodrud-Doza, M., Uddin, M. K., 2020. Pesticide exposures towards health and environmental hazard in Bangladesh: A case study on farmers' perception. Journal of the Saudi Society of Agricultural Sciences, 19: 161173.

Sharma, A., Kumar, V., Shahzad, B., Tanveer, M., Sidhu, G. P. S., Handa, N., Kohli, S. K., Yadav, P., Bali, A. S., Parihar, R. D., Dar, O. I., 2019. Worldwide pesticide usage and its impacts on ecosystem. Applied Sciences, 1: 1446.

Sharma, N. and Razdan, V. K., 2012. Perpetuation of Phomopsis vexans on infected seeds, leaf and fruit parts of Solanum melongena L (Brinjal). VEGETOS: International Journal of Plant Research. 25: 196-202.

Sharma, N. and Sharma, D. K., 2014. Incidence and seed transmission of R. solanacearum (Smith) in brinjal (Solanum melongena L.) seeds. International Journal of Plant Pathology, 5: 63-69.

Shelton, A. M., Hossain, M. J., Paranjape, V., Azad, A. K., Rahman, M. L., Khan, A. S. M. M. R., Prodhan, M. Z. H., Rashid, M. A., Majumder, R., Hossain, M. A., Hussain, S. S., 2018. Bt eggplant project in Bangladesh: history, present status, and future direction. Frontiers in Bioengineering and Biotechnology, 6: 106.

Shepard, B. M., Hammig, M. D., Carner, G. R., Ooi, P. A. C., Smith, J. P., Dilts, R., Rauf, A., 2009. Implementing Integrated Pest Management in Developing and Developed Countries. In: Peshin, R., Dhawan, A. K. (Eds.), Integrated pest management: dissemination and impact. Springer, Dordrecht, pp. 275-305.

Srinivasan, R. 2008. Integrated Pest Management for eggplant fruit and shoot borer (Leucinodes orbonalis) in south and southeast Asia: Past, Present and Future. Journal of Biopesticide, $1: 105-112$.

Srinivasan R. 2009. Insect and mite pests on eggplant: a field guide for identification and management. AVRDC Publication No. 09-729, AVRDC - The World Vegetable Center, Shanhua, Taiwan. 64 p. 
Stern, V. M., Smith, R. F., van den Bosch, R., Hagen, K.S. (1959) The integrated control concept. Hilgardia, 29: 81-101.

Sumon, K. A., Rashid, H., Peeters, E. T., Bosma, R. H., Van den Brink, P. J., 2018. Environmental monitoring and risk assessment of organophosphate pesticides in aquatic ecosystems of northwest Bangladesh. Chemosphere, 206: 92-100.

Theiling, K. M. and Croft, B. A., 1988. Pesticide side-effects on arthropod natural enemies: a database summary. Agriculture, Ecosystems and Environment, 21:191-218.

Tripp, R., Wijeratne, M., Piyadasa, V. H., 2005. What should we expect from farmer field schools? A Sri Lanka case study. World Development, 33: 1705-1720.

Van den Berg, H. and Jiggins, J., 2007. Investing in farmers - the impacts of farmer field schools in relation to integrated pest management. World Development, 35: 663-686.

Way, M. J. and Van Emden, H. F., 2000. Integrated pest management in practice-pathways towards successful application. Crop Protection, 19: 81-103.

Weinberger, K. and Genova C. A. II, 2005. Vegetable Production in Bangladesh: Commercialization and Rural Livelihoods. Technical Bulletin no. 33. AVRDC - The World Vegetable Center, Shanhua, Taiwan, $64 \mathrm{p}$.

Weinberger, K. and Lumpkin, T.A., 2007. Diversification into horticulture and poverty reduction: a research agenda. World Development, 35(8), 1464-1480.

Weinberger, K. and T. A. Lumpkin. 2005. Horticulture for Poverty Alleviation: The Unfunded Revolution. Taiwan: The World Vegetable Center, $51 \mathrm{p}$.

World Bank, 2005. Sustainable Pest Management: Achievements and Challenges. Report 32714 GBL, World Bank, Washington, DC.

Wyckhuys, K. A. G., Heong, K. L., Sanchez-Bayo, F., Bianchi, F. J. J. A., Lundgren, J. G., Bentley, J. W., 2019. Ecological illiteracy can deepen farmers' pesticide dependency. Environmental Research Letters, 14: 093004.

Zalucki, M. P., Adamson, D., Furlong, M. J., 2009. The future of IPM: whither or wither? Australian Journal of Entomology, 48: 85-96. 


\section{Reducing damping-off problems in eggplant (Solanum melongena L.): a participatory testing of nursery management in Bangladesh}

Naznin Nahar ${ }^{\mathrm{a}, \mathrm{b}}$, Md. Rashidul Islam ${ }^{\mathrm{a}}$, Mohammad Mahir Uddin ${ }^{\mathrm{a}}$, Peter de Jong ${ }^{\mathrm{b}}$, Paul C.

Struik $^{\mathrm{b}}$, Tjeerd-Jan Stomph ${ }^{\mathrm{b}}$

${ }^{\text {a }}$ Faculty of Agriculture, Bangladesh Agricultural University (BAU), Mymensingh 2202,

Bangladesh

${ }^{\mathrm{b}}$ Department of Plant Sciences, Wageningen University and Research Centre (WUR), 6708

PB Wageningen, The Netherlands

Published as: Nahar, N., Islam, M. R., Uddin, M. M., de Jong, P., Struik, P. C. and Stomph, T. J., 2018. Reducing damping-off problems in eggplant (Solanum melongena L.): A participatory testing of nursery management in Bangladesh. Crop Protection, 112: 177-186. https://doi.org/10.1016/j.cropro.2018.05.024 


\title{
Chapter 2
}

\begin{abstract}
Eggplant seedling production in homestead nurseries of farmers in Jamalpur (Bangladesh) is greatly compromised by damping-off. Therefore, farmers often do not have enough seedlings to transplant. Effective treatments of soil and seed to reduce disease pressure in the nurseries are available but little is known on the relative contributions of soil-borne and seed-borne pathogens to damping-off and on how nursery management can integrate management options under farmers' conditions. A 2-year nursery study was conducted in consecutive seasons, jointly with farmers and using farmers' preserved seed and farmers' nurseries subject to damping-off problems. Year 1 involved a single nursery, Year 2 nine nurseries. The following treatments were tested: Trichoderma harzianum as soil amendment combined with seed treatment using either hot water or Carbendazim and farmers' conventional practice: curative spraying after appearance of damping-off. In Year 1, a control (no intervention) treatment was also included. Emergence of seedlings, incidence of damping-off, seedling performance variables and farmers' appreciation of seedling vigour were recorded. Soil treatment with $T$. harzianum combined with seed treatment with hot water increased seedling emergence and produced 25-64 percentage points more healthy seedlings than farmers' conventional practice. This combined treatment also improved seedling performance (height, root length, lateral root development), and reduced stem girdling, a symptom associated with disease infection of transplants. To determine the contributions of nursery soil and farmers' seed to damping-off, blotter and in vitro studies in the laboratory and tray studies in a screen house were performed. Soil proved to be the major pathogen source and treating nursery soil with T. harzianum had the largest positive effect on seedling performance, both reducing damping-off and enhancing seedling growth.
\end{abstract}

Keywords: Damping-off, Integrated pest management, Seed treatment, Soil treatment, Source of pathogens, Healthy seedlings 


\section{Introduction}

Eggplant (Solanum melongena L.) is an important vegetable crop in Bangladesh because of its high consumption and economic value to farmers. As eggplant can be harvested and sold weekly, it plays a pivotal role in the livelihood of small land-holders especially. However, cultivation sustainability is greatly compromised by cascades of diseases from the nursery to the field and damping-off in the nursery is a major contributor (Singh, 1992; Pagoch et al., 2015). Damping-off generally appears as pre-emergence loss involving failure to emerge and as post-emergence loss involving rotting and collapsing of seedlings at their base (Lamichhane et al., 2017). Damping-off is not limited to eggplant alone and has been found to affect up to $80 \%$ (in worst cases even 100\%) of seedlings resulting in poor seedling stands in nurseries of various crops (Gupta and Paul, 2001; Lamichhane et al., 2017). Seedlings that survive from infected nurseries often show the so-called "wire stem" or "stem girdling" syndrome (i.e. a blackish sunken lesion girdles the base of the stem, the stem becomes thin and hard, especially at soil level, and may bend or twist) resulting in reduced vigour (Laemmlen, 2001; Lamichhane et al., 2017). Transplanting such seedlings likely leads to carry-over of pathogens to the main field. Thus damping-off causes severe economic losses to farmers not only by constraining production of sufficient healthy seedlings to transplant but also by carrying diseases into production fields (Singh, 1995; Pagoch et al., 2015; Lamichhane et al., 2017).

In Bangladesh, farmers usually raise eggplant seedlings in their homestead nurseries in JulyAugust when most land is not available for agriculture due to regular flooding. Moreover, preliminary interviews with farmers indicated that farmers who lose their complete nursery rarely have any option to sow a second batch as the delay would result in failing to fetch the higher price of the first few weeks of the harvesting season. Alternatively, they may buy or "borrow" leftover seedlings of poor quality from neighbours or relatives. Thus, it is a challenge to produce the required amount of healthy seedlings combating damping-off in the limited available time and land.

Infected seeds, soils and seedlings serve as a primary inoculum source for epidemics in nurseries and production fields of various crops including eggplant (Somda et al., 2008; Sharma and Razdan, 2012). Eggplant farmers use their own preserved seed, which possibly carries infections from the previous year (Islam and Meah, 2011). Farmers establish nurseries in the same plots year after year as land is scarce; very likely, all these plots are contaminated. Damping-off pathogens can survive for many years in the soil once established (Menzies, 1963; Lamichhane et al., 2017). Disease management often becomes complicated by the presence of 


\section{Chapter 2}

multiple types of pathogens from multiple sources. Here, combining protective and curative treatments against soil-borne and seed-borne pathogens will therefore be required.

Applying pesticides is a common method to control pests in developing countries, including Bangladesh (Ecobichon, 2001; Schreinemachers et al., 2016; Gautam et al., 2017). Farmers repeatedly apply pesticides both in nurseries and fields. Spraying is not only harmful for the environment and farmers' health, if not effective it also is a drain on household income. Spraying in home gardens poses risks to poultry, livestock and children (Dasgupta et al., 2007). Frequent use of fungicides has led to the development of resistance in pathogens against such fungicides while it negatively affects non-target organisms (Tjamos et al., 1992; Pingali, 1995; Gerhardson, 2002; Fernando et al., 2007; Lamichhane et al., 2017). In the study area the broadspectrum systemic fungicide, Carbendazim, is available to farmers and sprayed in nurseries. Treating seed with such a fungicide is sometimes considered an effective chemical treatment with a relatively small impact on the environment compared to spraying, because little active ingredient is needed. However, such products might better be avoided and replaced by cheap and more sustainable alternatives to pesticides for eggplant growers of Bangladesh.

With respect to soil-borne pathogens, Trichoderma spp. are well-documented bio-control agents against a wide range of such pathogens involving several mechanisms: antibiosis, mycoparasitism, promotion of plant growth and plant defensive mechanisms by induction of resistance, competition with pathogens for nutrients and space, and modification of the environmental conditions (Yedidia et al., 2001; Benitez et al., 2004; Harman et al., 2004; Howell, 2006; Verma et al., 2007; Hermosa et al., 2012). Soil amendment with Trichoderma spp. has been reported to control various pathogens in a range of crops (Harman, 2000; Prasad et al., 2002; Chakraborty and Chatterjee, 2008; Kapoor, 2008; Dubey, 2011; Molla et al., 2012; Bisutti et al., 2017; Doni et al., 2017). With respect to seed-borne pathogens, hot water treatment of seed is considered to be an effective method to control such pathogens and enhance germination without any detrimental environmental effects (Nega et al., 2003; reviewed in Mancini and Romanazzi, 2013).

There are no reports available from Bangladesh regarding damping-off control in eggplant nurseries using an integrated pest management (IPM) approach or on joint experimentation with farmers. A few reports are available on testing the effect of Trichoderma spp. or seed treatments on vegetables in controlled or on-station experiments (Uddin et al., 2009; Islam and Meah, 2011; Mia et al., 2016 ). Decades ago the IPM laboratory of Bangladesh Agricultural University developed a seed treating machine and formulated Trichoderma harzianum to treat the soil but 
farmers do not seem to apply these techniques (Meah, 2003; Meah, 2007). Thus, these IPMbased techniques remained "on the shelf" and further participatory testing to integrate them into farmers' nursery management practice was needed. In fact, farmer participation in experimentation allows much better than on-station research to assess what is achievable under farmers' conditions rather than only what is technically perfect (Morse \& Buhler, 1997; Morse, 2009; Parsa et al., 2014). Therefore, there was a need to develop a sustainable nursery disease management approach in collaboration with eggplant growers of Bangladesh.

The aim of the current study was to analyse effects and suitability of IPM strategies by combining available alternative control methods to reduce damping-off and produce vigorous and healthy eggplant seedlings under farmers' conditions. In addition, we aimed to establish under semi-controlled conditions the relative importance of soil and seed obtained from farmers as origin of the pathogen. We conducted a participatory nursery study with farmers combining available soil and seed treatments: treating soil with the biocontrol agent $T$. harzianum and treating seeds either with hot water or with the fungicide Carbendazim. Additional laboratory and screen house studies were conducted to determine i) pathogen incidence in soil and seeds, ii) the relative contribution of both origins in causing damping-off, iii) the relative contribution of different treatment components (hot water, Carbendazim, T. harzianum) alone and in combination in reducing damping-off and improving seedling vigour.

\section{Materials and methods}

\subsection{Study site}

A participatory nursery study was carried out in Pirijpur village $\left(25^{\circ} 02^{\prime} 13^{\prime \prime} \mathrm{N}-89^{\circ} 50^{\prime} 08^{\prime \prime E}\right)$, Jamalpur district, Bangladesh, located in the so-called Old Brahmaputra floodplain. Jamalpur district is the major eggplant growing area of Bangladesh. Farmers cultivate eggplants in the Brahmaputra river floodplain during the cool dry season (Rabi season: September-March).

\subsection{Participatory nursery study}

Prior to the start of the nursery studies, treatments were jointly established between the research team and the farmers. In that negotiation process, farmers clearly indicated their interest in also testing the locally available chemical seed treatment while researchers proposed the inclusion of the more sustainable hot water seed treatment and soil application of T. harzianum, both novel to the farmers. 


\section{Chapter 2}

\subsubsection{Study in Year 1}

A single farmer nursery, which was subject to damping-off problems in previous years, was used to test four treatments: (i) a combination of soil treatment with T. harzianum and physical (hot water) treatment of seeds; (ii) a combination of soil treatment with $T$. harzianum and chemical (Carbendazim) treatment of seeds; (iii) a farmer control [i.e. weekly spraying of Carbendazim from appearance of damping-off to final uprooting, i.e. 33-35 days after sowing (DAS)]; and (iv) a no intervention control. The experiment used a randomized complete block design ( $2 \mathrm{~m}$ by $2 \mathrm{~m}$ plots) with seven replicates, where the seven participating farmers each managed one replicate and donated their seeds for their own replicate; all farmers in the area used the same local variety. After negotiation with farmers, $2 \mathrm{~g} \mathrm{~m}^{-2}$ seed was broadcasted per plot, a rather low density as per farmer assessment. The number of seeds per gram was counted in triplicates and found to be $253 \pm 11.1(\mathrm{n}=7)$ on average across farmers.

Cultured T. harzianum suspension was obtained from the Bangladesh Agricultural University IPM laboratory (BAU-IPM); $25 \mathrm{~mL}$ of the suspension containing $12 \times 10^{6} \mathrm{CFU} / \mathrm{mL}$ was added per kg of a 1/1 mixture of peat soil and black gram (Vigna mungo (L.) Hepper) bran. Some 7-10 days before sowing $8 \mathrm{~g} \mathrm{~m}^{-2}$ of the mixture was incorporated into the top $10 \mathrm{~cm}$ of the nursery soil. A machine designed by the BAU-IPM Lab was used to clean the seeds. The machine consisted of a water bath with an electrical heating unit, timer and temperature control. The bath was filled with $2 \mathrm{~L}$ of water that was then heated to $50^{\circ} \mathrm{C}$, while stirring the water. Batches of $20 \mathrm{~g}$ of seeds were placed in a cotton bag and immersed for 15 minutes, while water was stirred and temperature was controlled at $50-55^{\circ} \mathrm{C}$. Hereafter seeds were removed from the bag, placed on clean tissue, dried and then sown. Chemical seed treatment was done with Carbendazim (Knowin 50 WP, Mcdonald Bangladesh, $500 \mathrm{~g}$ a.i. $\mathrm{kg}^{-1}$ ) using $2 \mathrm{~g}$ a.i./10 mL water $\mathrm{kg}^{-1}$ seed; this fungicide is available from village dealers in the area. Seeds were treated in batches of $10 \mathrm{~g}$. Fungicide solution and seeds were placed in a plastic container, mixed by gentle shaking nearly 1 minute to ensure total coverage of seeds. Then seeds were air dried on clean tissues for 30 minutes and sown. As farmers' control treatment, Knowin 50 WP was sprayed weekly as per manufacturer's recommendation using $0.1 \mathrm{~g} \mathrm{~m}^{-2}$ using $1 \mathrm{~g} / 0.5 \mathrm{~L}$ of water after appearance of damping-off to final uprooting of seedlings.

Each plot was monitored daily for emergence and onset of damping-off. When full emergence occurred (10 DAS), the total number of seedlings per plot was counted as final emergence. Damping-off over time was recorded on every alternate day from onset until it stabilized (13-21 DAS). Seedlings that were damped-off were counted and removed from plots. 
At transplanting (33-35 DAS), seedling growth parameters were recorded. Per plot, 100 random seedlings were uprooted and seedlings were sorted with farmers into three categories and counted. Categories included: good quality, moderate but acceptable quality, and poor quality based on a qualitative assessment of: seedling height, rooting depth, number of lateral roots, stem diameter at base of the seedling and girth ratio (ratio between diameter at stem base and midway the stem). Hereafter 10 random seedlings from the 100 seedlings that had been evaluated per plot were taken to measure root length, shoot length, numbers of leaves and lateral roots, stem diameter at base and midway the stem. Farmers also anonymously scored each other's seedlings as a batch based on overall growth of seedlings especially of seedling height, leaf greenness, stem diameter, stem girth ratio and number of lateral roots using a 3-point scale (good, moderate and poor). Seedling vigour index was calculated using a modified formula based on Abdul-Baki and Anderson (1973):

Vigour index $=($ Mean root length + Mean shoot length $) \times$ fraction emergence $\quad$ Eq. 1

\subsubsection{Study in Year 2}

In Year 2, the following changes were made to the protocol of Year 1: the untreated control was left out reducing the number of treatments to three. A total of nine farmers participated, every farmer testing his conventional treatment (farmers' practice) against one of the two improved nursery practices. Five farmers tested the combination of T. harzianum and hot water and four farmers tested the combination of T. harzianum and Carbendazim. As in the first year, $2 \mathrm{~g} \mathrm{~m}^{-2}$ seeds were broadcasted in the improved nursery plots $(2 \mathrm{~m}$ by $2 \mathrm{~m})$ and, following farmers' practice, 7.5-16 $\mathrm{g} \mathrm{m}^{-2}$ seeds were broadcasted in farmers' conventional plots. The average number of seeds per gram $(225.1 \pm 17.5, \mathrm{n}=9)$ and the exact quantity of seeds were recorded.

Full emergence was recorded at 8 DAS and damping-off over time was recorded from onset until it stabilized (9-23 DAS). At transplanting (33-34 DAS), 250 random seedlings per plot were uprooted for evaluation. With the assistance of a farmer trainer, farmers evaluated the seedlings and counted the number of seedlings in each of three categories: good, moderate and poor quality. Then, 30 random seedlings from the 250 seedlings evaluated per plot were measured for root length, shoot length, number of leaves and lateral roots. Farmers also anonymously scored each other's seedlings as in Year 1. 


\section{Chapter 2}

\subsection{Laboratory studies}

\subsubsection{Assessing pathogenic mycoflora on farmers' seed}

Seeds obtained from seven farmers who participated in Year 1 were subjected to a blotter test and an agar plate test recommended by the International Seed Testing Association (ISTA, 2017). For the blotter test, a pair of $85 \mathrm{~mm}$ diameter sterile blotter papers were soaked in sterile distilled water and placed in pre-sterilized $90 \mathrm{~mm}$ diameter Petri dishes. For each seed sample, 400 seeds were distributed over 16 replicates, with per Petri dish 25 evenly distributed seeds. Dishes were incubated at $28 \pm 2{ }^{\circ} \mathrm{C}$ under an alternate light and dark cycle of $12 / 12$ hours. After seven days, the number of uninfected seeds and seeds infected by various fungi was counted under a stereo binocular microscope $(50 \times)$. Fungal genera were confirmed by comparison with slides prepared from fungal growth on seeds.

For the agar plate test pre-sterilized Petri dishes were filled with $15 \mathrm{~mL}$ of autoclaved Potato Dextrose Agar (PDA), which was then left to cool down. Seeds were surface-sterilized with 1\% sodium hypochlorite $(\mathrm{NaOCl})$ solution and rinsed thrice with sterilized distilled water. Per seed sample 100 seeds were aseptically and evenly distributed over four replicates of 25 seeds. Plates were incubated at $28 \pm 2{ }^{\circ} \mathrm{C}$. After 7 days, fungi were identified under a compound microscope (100-1000 $\times)$ according to colony characteristics and morphology of sporulation structures. If multiple fungal colonies grew on a single seed and colonies were mixed, only the most conspicuous colony was counted. The percentage frequency was calculated according to AlAskar et al. (2014):

Frequency $(\%)=\frac{\text { number of seeds with a fungal species }}{\text { number of tested seeds }} \times 100$

Eq. 2

\subsubsection{Assessing pathogenic mycoflora in farmers' nursery soil}

Soil samples were taken from each homestead nursery of seven farmers who participated in the first-year study and also from the field where we carried out the nursery study in Year 1. Five soil cores were taken from the top 10 to $15 \mathrm{~cm}$ depth and combined per farmer. These pooled samples were carefully transferred to sterile plastic bags and transported to the laboratory within 24 hours after collection. In the lab, soil samples were air-dried for 3 days, sifted with a 2-mm mesh sieve and stored for less than a month at $4{ }^{\circ} \mathrm{C}$ until testing. Fungal genera were determined by soil dilution plating on potato dextrose agar. To avoid bacterial contamination, the media were supplemented with the antibiotic streptomycin. For each collected soil sample, $1 \mathrm{~g}$ of soil was added to $10 \mathrm{~mL}$ of double distilled water, vigorously stirred for 15 minutes, and serially 
diluted from $10^{-1}$ to $10^{-4}$. Dilution $10^{-4}$ was used to isolate fungi. Hundred microliter of the $10^{-}$

${ }^{4}$ dilution was added to each of five sterile Petri dishes per soil sample. The Petri dishes were incubated at $28 \pm 2{ }^{\circ} \mathrm{C}$ for 7 days. Based on colony morphology and microscopic observations, the most frequently occurring fungi were selected and subjected to purification following subculturing. The fungal genera were confirmed macroscopically by distinctive colony morphology and microscopically by mycological keys (Watanabe, 1994; Dugan, 2008).

\subsection{Screen house studies}

Screen house studies were carried out at the BAU seed pathology centre between January and March 2017. Average maximum temperature over the period was $27.4{ }^{\circ} \mathrm{C}$ and minimum was $21.9^{\circ} \mathrm{C}$ (Weather yard, BAU, Mymensingh). In all below described studies, full emergence occurred 10-12 DAS and damping-off started just after emergence and continued up to 24 DAS. Emergence was monitored until full emergence and total number of seedlings/tray was counted. Then number of surviving and damped-off seedlings/tray were counted over time until damping-off stopped. Damped seedlings were removed upon scoring to avoid errors.

\subsubsection{Role of seed and soil in damping-off}

To assess the relative contribution of seed and soil in causing damping-off two randomized complete block experiments were conducted, each with five replicates as blocks and two factors: soil sterilizing (either unsterilized or sterilized) and seed sterilizing (either unsterilized or sterilized) which were orthogonally combined to four treatments. Seeds were treated with hot water as in the participatory nursery study. Soil was decontaminated by mixing $4 \%$ formaldehyde solution using $28 \mathrm{~mL}$ per $\mathrm{kg}$ soil, formaldehyde is a standard chemical control of soil borne biota (Lawrence, 1956; Dasgupta, 1988). We used in one study a lowly contaminated and in a second study a highly contaminated seed lot, as established with the blotter and agar plate tests (Section 2.3.1). The soil used in these studies was taken from highly infected plots of the participatory nursery study field. Aseptic trays $(0.3 \mathrm{~m} \times 0.2 \mathrm{~m})$ were filled with $4 \mathrm{~kg}$ of soil. Per tray, 100 seeds were regularly placed with a blunt forceps in four shallow furrows at 25 seeds each after which they were covered with a very thin layer soil. Emergence and damping-off were recorded as described above.

2.4.2. Role of Trichoderma harzianum, hot water and Carbendazim alone and combined in reducing damping-off

To determine the role of soil application of T. harzianum and seed treatment with hot water or with Carbendazim alone or in combination a randomized complete block design with five 


\section{Chapter 2}

replicates was carried out with six treatments: i) T. harzianum and hot water; ii) T. harzianum alone; iii) formaldehyde alone; iv) hot water alone; v) Carbendazim alone; and vi) an untreated control. The most infected seed lot as established by the blotter and agar plate tests (Section 2.3.1) and highly infected soil from one of the farmer's homestead nurseries were used in this experiment. Aseptic trays $(0.3 \mathrm{~m} \times 0.2 \mathrm{~m})$ were filled with $4 \mathrm{~kg}$ of soil. The hot water and Carbendazim treatments of the seed were carried out as in the participatory nursery study (Section 2.2.1). Soil was either treated with $4 \%$ formaldehyde as described in Section 2.4.1 as a standard soil mycoflora control or amended with T. harzianum as biological control. $T$. harzianum was applied at $1 \mathrm{~g} /$ tray, based on the formulation described in Section 2.2.1, 10 days before sowing. Per tray, 100 seeds were placed in 4 rows of 25 seeds. Emergence and dampingoff over time were recorded as described above. From this study, seedling growth was also recorded: 10 random seedlings per tray were uprooted 34 DAS and root length, shoot length and leaf area were recorded. Weight of 10 seedlings per tray was measured after drying them at $70^{\circ} \mathrm{C}$ for $72 \mathrm{~h}$.

\subsection{Statistical analyses}

Data were subjected to ANOVA by statistical package RX64 version 3.2.0. Residuals were checked for normality and homogeneity with the Shapiro-Wilkinson test and the Levine's test, respectively. Tukey's HSD test was used for mean separation.

\section{Results}

\subsection{Participatory nursery study}

\subsubsection{Emergence and survival of seedlings}

In both years, the percentage of seeds that failed to emerge ('pre-emergence loss') significantly decreased ( $P<0.05$, Fig. 1) and the percentage of healthy seedlings of sown seeds at the time of transplanting significantly $(P<0.05)$ increased compared to farmers' conventional practice when soils were treated with $T$. harzianum and seeds with hot water. Farmers' conventional practice did not affect pre- or post-emergence losses compared to the 'no treatment' control as tested in Year $1(P>0.05$, Fig. 1). When the hot water treatment of seeds was replaced by treatment with Carbendazim the pre-emergence loss was in between the farmers' practice and the hot water treatment and not significantly different $(P>0.05)$ from either one in Year 1. In Year 2, both Carbendazim and hot water treatment of seeds reduced pre-emergence losses compared to farmers' practice (Fig. 1). A comparable pattern was observed for the postemergence losses through damping-off in both years, even though the percentage pre- 
emergence losses under farmers' practice differed between years. The second year the "farmers' practice" treatment was left completely to the farmers while in the first year the sowing density was controlled to correspond to that in the other treatments. In Year 2, this led to a difference in sowing density between the improved practices $\left(2 \mathrm{~g} \mathrm{~m}^{-2}\right)$ and the farmers' practice plots (7.5$16 \mathrm{~g} \mathrm{~m}^{-2}$ ). Including sowing density in the analyses did not significantly contribute to the explanation of the observed differences between treatments $(P>0.10$, data not shown), so this factor was not further considered in our analyses.

The progress of the post-emergence damping-off loss (Fig. 2) started to differ among treatments soon after emergence in both years (13 and 9 DAS in Year 1 and Year 2, respectively), while differences started to stabilize by 21 DAS. The combined soil and seed treatment showed significantly $(P<0.05)$ reduced damping-off over time and cumulative postemergence damping-off of emerged seedlings at 21 DAS was lower by $20-40$ percentage points compared to farmers' conventional practice (Fig. 2).

\subsubsection{Seedling growth}

At transplanting (33-35 DAS) the seedlings from soil treated with T. harzianum combined with seed treated either with hot water or Carbendazim differed significantly $(P<0.05)$ from seedlings raised under farmers' conventional practice (both years) or untreated control (Year 1) for all observed seedling variables (Table 1). No differences were observed between farmers' conventional practice and untreated control or between the two seed treatments. Seedling height, root length, number of lateral roots and the overall vigour index of seedlings from the improved management treatments were more than double the values reported for seedlings from farmers' conventional practice (Table 1). So-called 'stem girdling' was observed as symptom indicative of potential failure after transplanting by measuring the ratio between girth at stem base and the middle of the stem. This girth ratio was significantly $(P<0.05)$ higher, indicating less risk of seedling failure, for seedlings raised on T. harzianum treated soil from hot water or Carbendazim treated seeds than for seedlings raised under conventional practices. At least $80 \%$ of the seedlings showed girth ratios of one or higher for improved management treatments compared to around $30 \%$ for farmers' practice (Table 1 ). 


\section{Chapter 2}

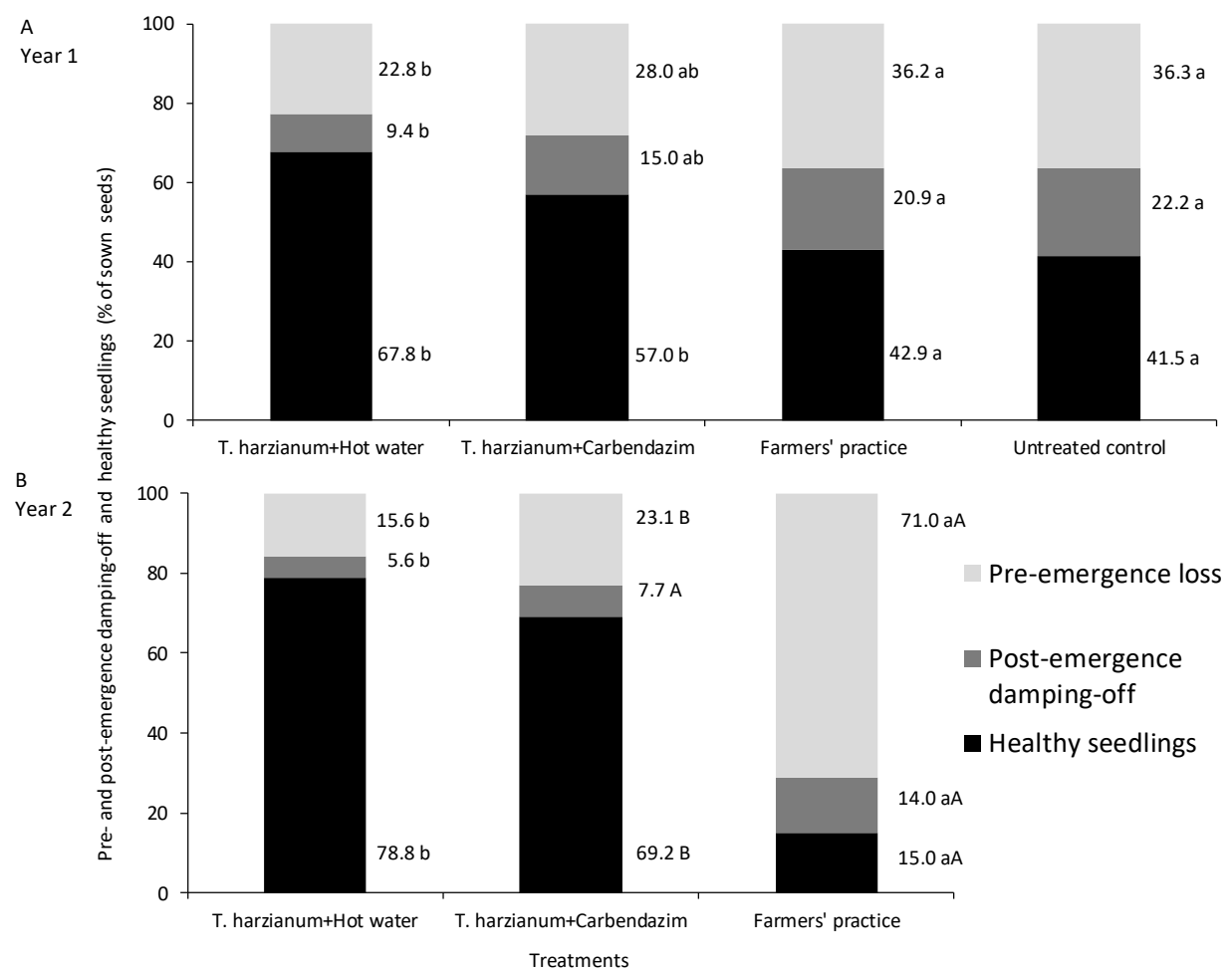

Fig. 1. Pre-emergence loss, post-emergence damping-off and healthy seedlings (\% of sown seeds) on plots treated with $T$. harzianum combined with either a seed treatment with hot water or with Carbendazim and farmers' conventional practices (spraying after appearance of damping-off) in a 2year nursery study. The combination of healthy seedlings and post-emergence damping-off equals percentage emergence. In Year 1, also an untreated control was included. In Year 1, seven replicates for all treatments were sown and all treatments used the recommended sowing density $\left(2 \mathrm{~g} \mathrm{~m}^{-2}\right)$. In Year 2 , five replicates of the T. harzianum with hot water treatment and four replicates of the T. harzianum with Carbendazim treatment were sown at the recommended sowing density like in Year 1, whereas farmers' practice (in total nine replicates) was sown at the higher density farmers usually practise $\left(7.5-16 \mathrm{~g} \mathrm{~m}^{-2}\right)$. The data on farmers' practice in Year 2 are the averages of all nine replicates. For each variable, values within a year followed by the same letter and font case are not significantly different $(\mathrm{P}>0.05)$ according to Tukey's HSD test. 


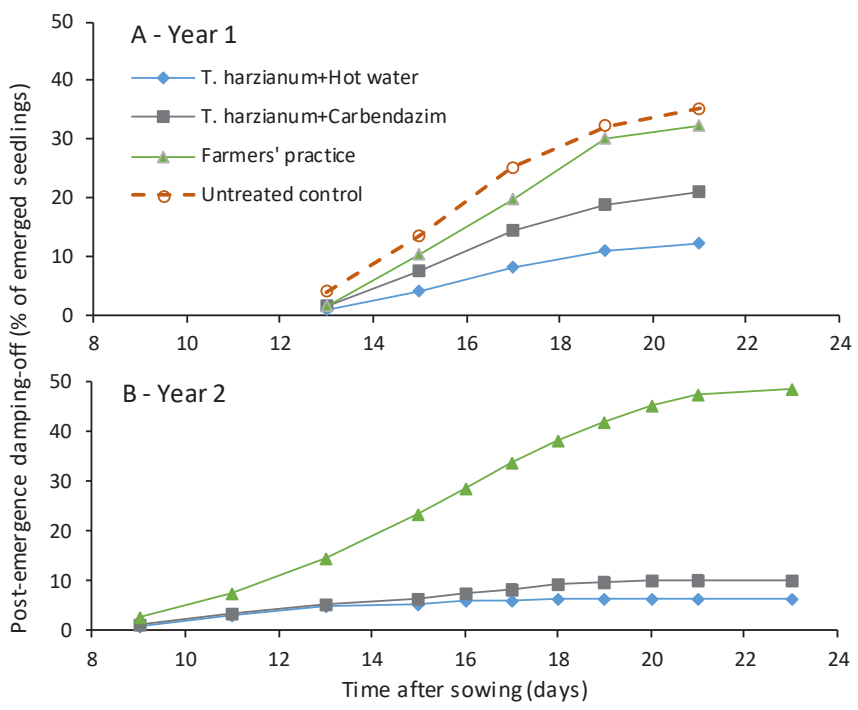

Fig. 2. Post-emergence damping-off of eggplant seedlings (\% of emerged seedlings) between emergence and until it stabilized on plots treated with $T$. harzianum combined with either a seed treatment with hot water or with Carbendazim and farmers' conventional practices (spraying after appearance of dampingoff) in a 2-year nursery study. In Year 1, also an untreated control was included. In Year 1, both $T$. harzianum treatments at all observations showed significantly $(P<0.05)$ lower damping-off than the untreated control. T. harzianum with hot water showed lower damping-off at all observation dates than farmers' practice except at13 DAS, whereas T. harzianum with Carbendazim showed lower dampingoff from 19 DAS onwards. In Year 2, both $T$. harzianum treatments showed significantly $(P<0.05)$ lower damping-off than farmers' practice at all observation dates. For details on replication and sowing density see caption to Fig. 1 .

\subsubsection{Farmers' assessments}

In addition, farmers' placement of seedlings in three categories (good, moderate and poor) and appreciation obtained from scoring each other's seedlings clearly confirmed the relevance of these observations on growth parameters (Tables 2). In both years, farmers considered plant height, leaf greenness and stem diameter of seedlings from conventional practice plots as 'acceptable' but scored the two improved management treatments as 'best'. Girth ratio and number of lateral roots were scored as 'poor' for conventional seedlings and as 'best' for the improved management techniques (Table 2). According to farmers' evaluation of seedlings, based on a qualitative combination of seedling height, girth ratio, root length and number of lateral roots, 40-70 percentage points more seedlings were scored 'good' in improved management treatments compared to seedlings from farmers' conventional practice plots (Table 2). 


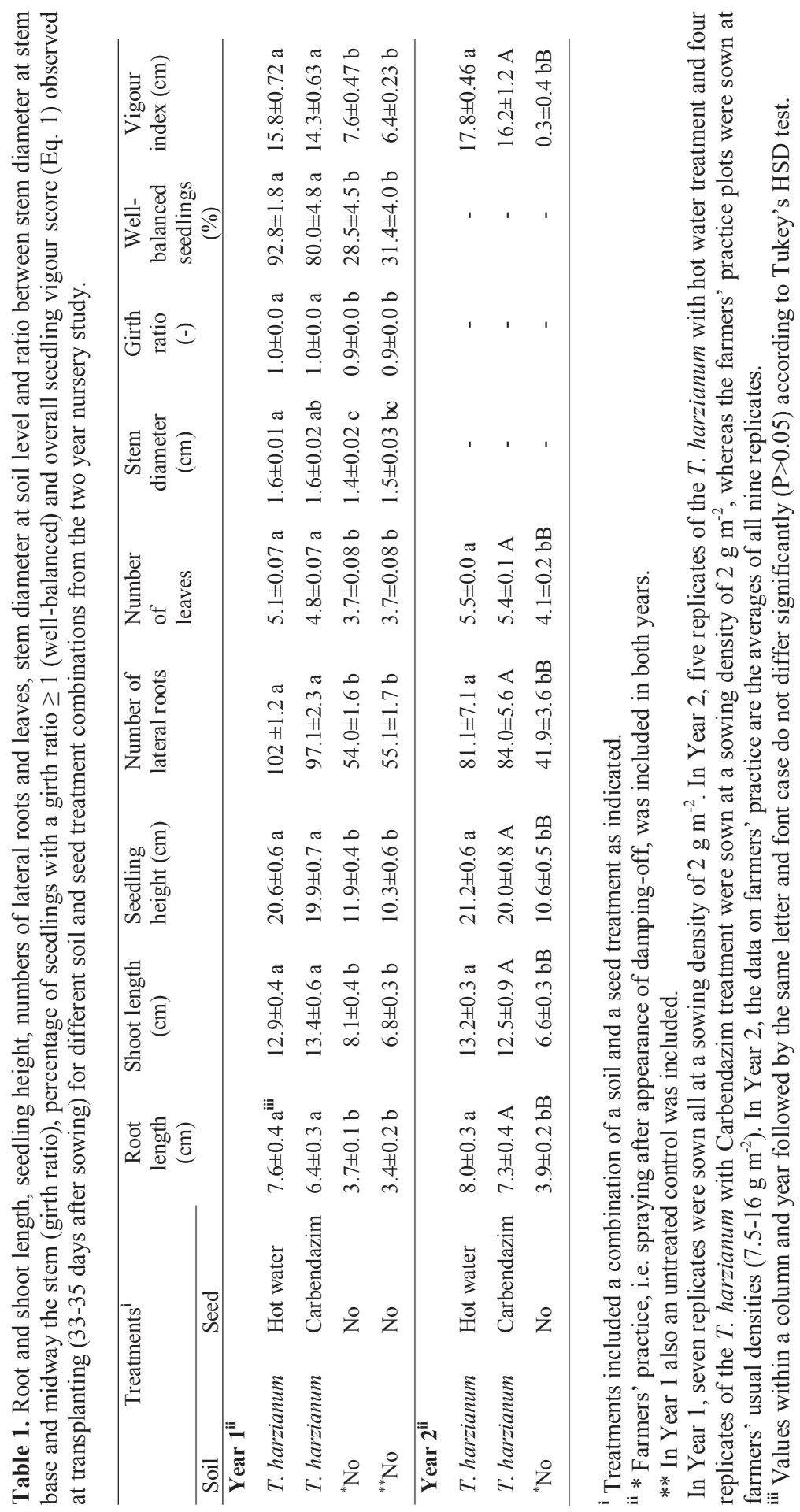




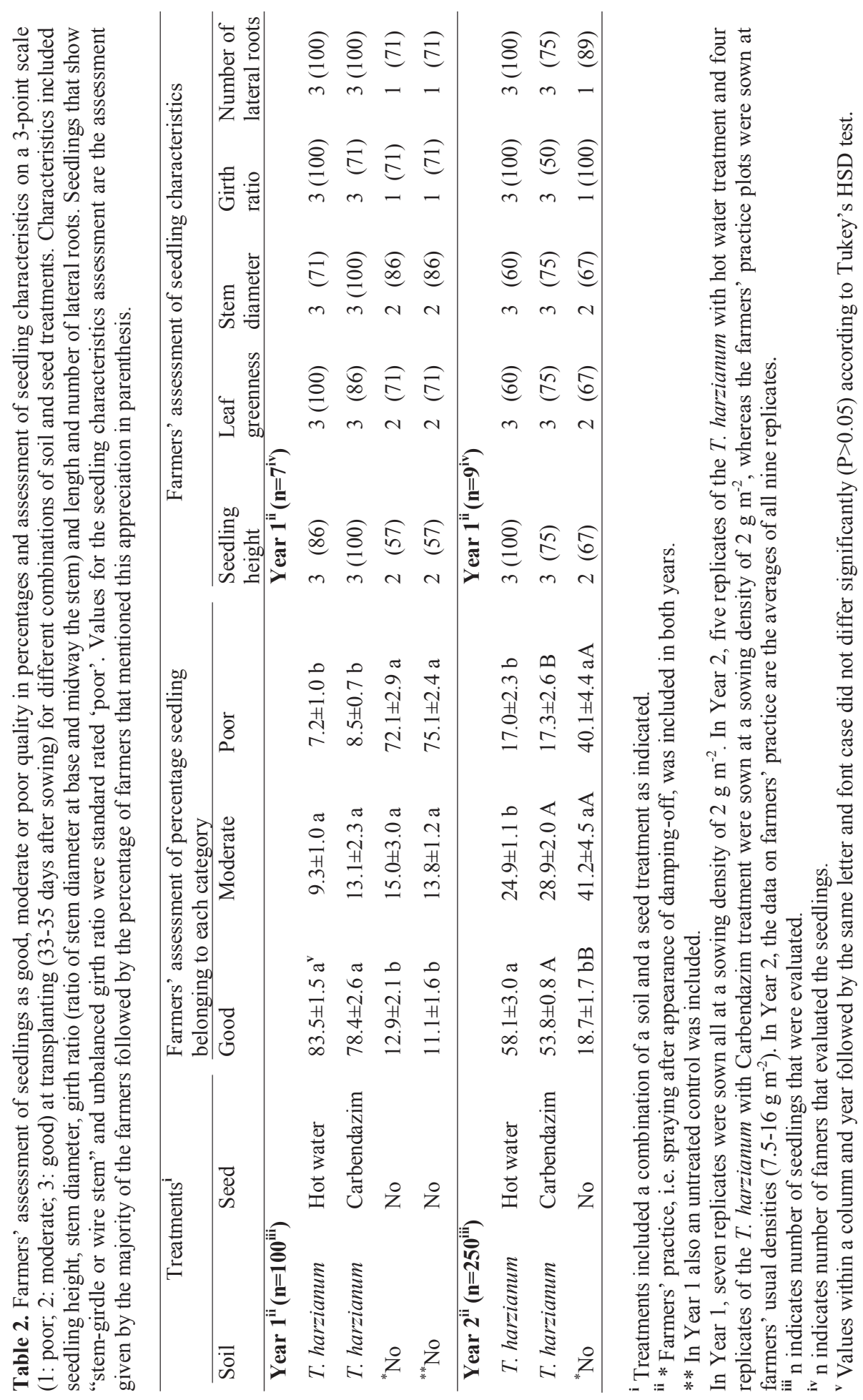




\section{Chapter 2}

\subsection{Laboratory studies - pathogen incidence in farmers' soil and seed}

Pathogen incidence linked to damping-off was assessed in blotter and agar plate tests for seeds obtained from farmers, who participated in the Year 1 nursery study. The tested, potentially pathogenic, fungi included Fusarium sp., Phomopsis sp., and Botrytis sp. In addition to these, Aspergillus flavus, Aspergillus niger and Penicillium sp. were observed (Table 3). Seed sample 1 appeared least contaminated and Sample 7 most contaminated from the tests based on scores on Fusarium sp. (Table 3).

Table 3. Percent incidence of fungal pathogens in farmers' seed as observed in a blotter and agar plate test.

\begin{tabular}{|c|c|c|c|c|c|c|c|}
\hline $\begin{array}{l}\text { Test } \\
\text { type }\end{array}$ & $\begin{array}{l}\text { Seed } \\
\text { sample } \\
\text { no }\end{array}$ & $\begin{array}{l}\text { Fusarium } \\
\text { sp. }\end{array}$ & $\begin{array}{l}\text { Phomopsis } \\
\text { sp. }\end{array}$ & $\begin{array}{l}\text { Botrytis } \\
\text { sp. }\end{array}$ & $\begin{array}{l}\text { Aspergillus } \\
\text { flavus }\end{array}$ & $\begin{array}{l}\text { Aspergillus } \\
\text { niger }\end{array}$ & $\begin{array}{l}\text { Penicillium } \\
\text { sp. }\end{array}$ \\
\hline \multirow{7}{*}{ Blotter } & 1 & -1 & - & - & 0.5 & 0.7 & 1.0 \\
\hline & 2 & - & - & - & 1.0 & 1.2 & 20.7 \\
\hline & 3 & - & - & - & 0.2 & 0.7 & 0.2 \\
\hline & 4 & - & - & - & 0.2 & 0.7 & 0.5 \\
\hline & 5 & - & - & - & 0.7 & 0.5 & 2.5 \\
\hline & 6 & - & - & - & 0.2 & 0.5 & 4.0 \\
\hline & 7 & - & - & - & 1.0 & 1.0 & 14.5 \\
\hline \multirow{7}{*}{$\begin{array}{l}\text { Agar } \\
\text { plate }\end{array}$} & 1 & 2.0 & 2.0 & 1.0 & 1.0 & 2.0 & 2.0 \\
\hline & 2 & 2.0 & 2.0 & 1.0 & 3.0 & 3.0 & 12.0 \\
\hline & 3 & 3.0 & 2.0 & 2.0 & 6.0 & 2.0 & 4.0 \\
\hline & 4 & 4.0 & 1.0 & 1.0 & 14.0 & 5.0 & 7.0 \\
\hline & 5 & 4.0 & 2.0 & 8.0 & 12.0 & 5.0 & 9.0 \\
\hline & 6 & 5.0 & 2.0 & 1.0 & 5.0 & 7.0 & 1.0 \\
\hline & 7 & 11.0 & 2.0 & 6.0 & 6.0 & 1.0 & 12.0 \\
\hline
\end{tabular}

${ }^{1}$ - denotes absence of the fungus.

Home garden soil of farmers, who participated in the $1^{\text {st }}$ year nursery study, and soil from the participatory nursery study field were tested on agar plates too. A larger range of fungal genera was observed from the soil samples than from the seed samples. All fungi observed on seeds were also observed in the soil, except Phomopsis sp. In addition Rhizoctonia sp., Sclerotium sp., Pythium sp., Phytophthora sp. were observed in the soil.

\subsection{Screen house studies}

3.3.1. Relative contribution of farmers' soil and seed in determining damping-off and healthy seedlings

Two seed lots, one with a low and another with a high pathogen incidence (Lots 1 and 7, respectively [Table 3]) were selected from the seed samples donated by the farmers. There was 
no interaction effect between the soil and seed sterilizing treatments in the test with Lot 1 (Table 4). This interaction could not be tested in the second study. Sterilizing the soil led in both studies to significantly $(P<0.05)$ higher percentages emergence and healthy seedlings and lower damping-off (Table 4). Percent emergence was reduced by 21 and 30-34 percentage points when the soil was not sterilized for the most and least contaminated seed lot, respectively. There was also a significantly higher loss of 5 and 9 percentage points of emerged seedlings to damping-off. Sterilizing the soil also significantly increased the percentage healthy seedlings in both studies either when taken as percentage of sown seeds or when taken as percentage of emerged seedlings (Table 4).

Table 4. Emergence, post-emergence damping-off and healthy seedlings as percentages of sown seeds and healthy seedlings as percentage of emerged seedlings for different combinations of soil and seed sterilization for two seed lots obtained from farmers during the participatory nursery study, one with low pathogen incidence (Lot 1: Sample 1 of Table 3) and one with a high pathogen incidence (Lot 2: Sample 7 of Table 3) as established during the in-vitro test reported in Table 3.

\begin{tabular}{|c|c|c|c|c|c|c|c|c|c|}
\hline \multicolumn{2}{|c|}{ Treatment } & \multicolumn{2}{|c|}{ Emergence (\%) } & \multicolumn{2}{|c|}{$\begin{array}{l}\text { Post- } \\
\text { emergence } \\
\text { damping-off } \\
(\%)\end{array}$} & \multicolumn{2}{|c|}{$\begin{array}{l}\text { Healthy } \\
\text { seedlings ( } \% \\
\text { of sown seeds) }\end{array}$} & \multicolumn{2}{|c|}{$\begin{array}{l}\text { Healthy } \\
\text { seedlings } \\
\text { (\% of emerged } \\
\text { seedlings) }\end{array}$} \\
\hline Soil & Seed & Lot 1 & Lot 2 & Lot 1 & Lot 2 & Lot 1 & Lot 2 & Lot 1 & Lot 2 \\
\hline Sterilized & Sterilized & $88.2 \mathrm{a}$ & $76.8 \mathrm{a}$ & $0.2 \mathrm{~b}$ & $0.4 \mathrm{~b}$ & $88.0 \mathrm{a}$ & $76.4 \mathrm{a}$ & $99.7 \mathrm{a}$ & $99.4 \mathrm{a}$ \\
\hline Sterilized & Unsterilized & $80.8 \mathrm{a}$ & $67.0 \mathrm{a}$ & $0.6 \mathrm{~b}$ & $1.0 \mathrm{~b}$ & $80.2 \mathrm{a}$ & $66.0 \mathrm{a}$ & $99.2 \mathrm{a}$ & $98.5 \mathrm{a}$ \\
\hline Unsterilized & Sterilized & $54.2 \mathrm{~b}$ & n.d. ${ }^{*}$ & $5.4 \mathrm{a}$ & n.d. & $48.8 \mathrm{~b}$ & n.d. & $89.0 \mathrm{~b}$ & n.d. \\
\hline Unsterilized & Unsterilized & $50.2 \mathrm{~b}$ & $46.0 \mathrm{~b}$ & $6.4 \mathrm{a}$ & $10.2 \mathrm{a}$ & $43.8 \mathrm{~b}$ & $35.8 \mathrm{~b}$ & $86.7 \mathrm{~b}$ & $77.1 \mathrm{~b}$ \\
\hline
\end{tabular}

Values within a column followed by the same letters do not differ significantly $(\mathrm{P}>0.05)$ according to Tukey's HSD test, " n.d. denotes no data

\subsubsection{Relative contribution of soil and seed treatments combined and alone to damping-off,} seedling survival and seedling growth

As we combined soil and seed treatments in the participatory nursery studies, the screen house studies were used to determine the contribution of treating only the soil or only the seed in reducing damping-off and producing healthy seedlings (Table 5). Seedling emergence and healthy seedlings as percentage of sown seeds increased by 13.8 and 29.2 percentage points, respectively, and incidence of post-emergence damping-off decreased by 15.4 percentage points when only soils were treated with $T$. harzianum compared to the untreated control (Table 5). This was comparable to the effect of using formaldehyde, showing the efficacy of the 


\section{Chapter 2}

biological control and showing damping-off could not be reduced to zero by either treatment. No further significant change in emergence, number of surviving or diseased seedlings was found when seeds were treated with hot water. In this screen house study only treating seeds with hot water had the same effect on emergence as only treating soil with $T$. harzianum, while this seed treatment did not reduce post-emergence damping-off. The hot water treatment of seed ultimately produced more healthy seedlings compared to the untreated control $(P<0.05)$. The seed treatment with Carbendazim resulted in an intermediate percentage of emergence that differed neither from the hot water nor from the untreated control. It also showed postemergence damping-off comparable to the control and produced an intermediate number of healthy seedlings which neither differed from the hot water treatment nor from the untreated control.

Table 5. Percentage emergence, post-emergence damping-off and healthy seedlings as percentages of sown seeds for different combinations of soil and seed treatments. Seeds in this test were from Sample 7 of Table 3 .

\begin{tabular}{llccc}
\hline Treatments & Seed & $\begin{array}{l}\text { Emergence } \\
\text { Soil }\end{array}$ & $\begin{array}{l}\text { Post-emergence } \\
\text { damping-off } \\
\text { (\% of sown seeds) }\end{array}$ & $\begin{array}{l}\text { Healthy seedlings (\% } \\
\text { of sown seeds) }\end{array}$ \\
\hline T. harzianum & Hot water & $73.2 \mathrm{a}$ & $3.0 \mathrm{~b}$ & $70.2 \mathrm{a}$ \\
T. harzianum & No & $70.8 \mathrm{a}$ & $4.2 \mathrm{~b}$ & $66.6 \mathrm{ab}$ \\
Formaldehyde & No & $70.0 \mathrm{a}$ & $1.2 \mathrm{~b}$ & $68.8 \mathrm{ab}$ \\
No & Hot water & $70.4 \mathrm{a}$ & $15.2 \mathrm{a}$ & $55.2 \mathrm{bc}$ \\
No & Carbendazim & $63.2 \mathrm{ab}$ & $15.8 \mathrm{a}$ & $47.4 \mathrm{~cd}$ \\
No & No & $57.0 \mathrm{~b}$ & $19.6 \mathrm{a}$ & $37.4 \mathrm{~d}$ \\
\hline
\end{tabular}

Values within a column followed by the same letters do not differ significantly $(\mathrm{P}>0.05)$ according to Tukey's HSD test

Seedling performance (Table 6) was best for seedlings from treatments that included $T$. harzianum amended soil irrespective of whether seeds were treated or not. Root length and shoot length increased by about $1 \mathrm{~cm}$ and $3 \mathrm{~cm}$, respectively, about one more leaf was present, and leaf area, seedling dry weight and vigour index increased nearly two fold compared with the untreated control and were all significant $(P<0.05$, Table 6$)$. Treating seeds with hot water only, showed significantly $(P<0.05)$ higher leaf area and vigour index than the untreated control. In all aspects of growth, seed treatment with Carbendazim did not differ $(P>0.05)$ from the hot water treatment of seed or the untreated control except for the leaf number and area which both were higher than for the control. 


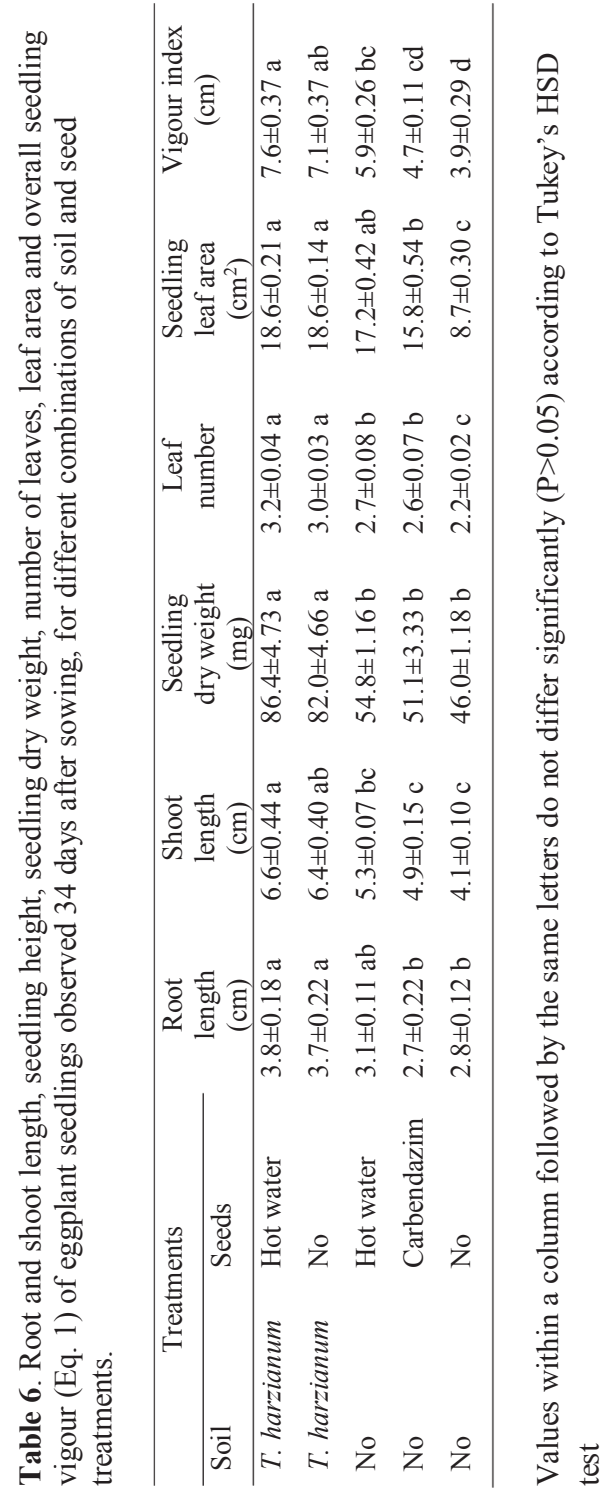




\section{Chapter 2}

\section{Discussion}

This study tested if soil application of T. harzianum in farmers' eggplant nurseries combined with a seed treatment either with hot water or Carbendazim could effectively improve emergence and reduce damping-off of seedlings and produce a higher number of healthy seedlings and more vigorous seedlings compared to farmers' conventional practice. Combining nursery inoculation with $T$. harzianum and seed treatment reduced damping-off losses and improved seedling emergence and quality as compared to farmers' conventional practice or no treatment at all (Fig. 1, Table 1). Laboratory and screen house studies further showed that soil was the major source of pathogens and treating soil with T. harzianum had the largest effect on damping-off control and on seedling vigour.

\subsection{Improved nursery management reduces both pre- and post-emergence damping-off}

Seedling emergence requires by definition the combination of germination and survival of seedlings until they appear above ground. The reduced emergence observed in the nursery studies could thus be both the consequence of lower germination or higher post-germination (but pre-emergence) death. While literature (Abd-El-Khair et al., 2010; Muthukumar et al., 2010) considers differences after soil or seed treatments as reduced pre-emergence dampingoff, treating seed with hot water could both reduce seed-borne pathogens and enhance germination per se and thus not all differences in emergence are automatically due to reduced pre-emergence damping-off. We observed similar effects on pre-emergence losses for the hotwater and Carbendazim treatments (Fig. 1, Table 5), while the fungicide treatment does not enhance germination. This makes it likely that the observed effects are largely through reduced pre-emergence damping-off.

Post-emergence damping-off started to differ between the control and improved management treatments from emergence (9-13 DAS) until it stabilized (21-23 DAS) (Fig. 2). This suggests that damping-off continued to affect seedlings after emergence. Finally, in both nursery studies, improved practices led to a higher number of healthy seedlings at transplanting through both reduced pre-emergence loss and reduced post-emergence damping-off (Fig.1).

There was a difference in the sowing density of the farmers' practice between the two nursery studies. In Year 1, upon negotiation, farmers agreed to reduce their seed rate to that of the improved practice $\left(2 \mathrm{~g} \mathrm{~m}^{-2}\right.$ plot) whereas in Year 2 farmers were allowed to test their preferred seed rates under farmers' practice which led to different seed densities between improved $\left(2 \mathrm{~g} \mathrm{~m}^{-2}\right)$ and farmers' practice $\left(7.5-16 \mathrm{~g} \mathrm{~m}^{-2}\right)$. This was accompanied by a much 
higher pre-emergence loss (71\% in Year 2 versus 36\% in Year 1). The higher sowing density may well have led to a higher chance of seed to seed (or seedling to seedling) contamination (Van Mourik et al., 2005; Narayanasamy, 2013). In fact also the post-emergence loss of emerged seedlings was higher in Year 2 than in Year 1 (Fig. 2). Here also the effect may have been partially due to a higher seedling to seedling contamination at the higher seed rates in the farmer control (Jurke and Fernando, 2006). Irrespective of this possible effect of sowing density the positive effect of the soil and seed treatments were highly significant in both years.

\subsection{Quality of surviving seedlings is higher with improved management}

In both nursery studies, improved nursery practices enhanced seedling quality for all observed variables as compared to farmers' practice (Table 1), also according to farmers' own appreciation (Tables 2). The most striking outcome from our study was production of at least 40 percentage points more seedlings without 'stem girdling' or 'wire stem' disorder (wellbalanced and good seedling as mentioned in Tables 1 and 2) indicating most likely pathogenfree seedlings (Keinath and Farnham, 2001). Also the enhanced stem diameter, plant height and root system are indications of healthy and vigorous seedlings capable of withstanding both biotic and abiotic stresses (Read and Stokes, 2006; Mastouri et al., 2010). These more vigorous and larger seedlings can be expected to perform better after transplanting (Harman, 2000; Mastouri et al., 2010). In fact, farmers in Bangladesh have limited options for seedling production after sudden nursery loss in case of end of rainy season flooding. As seedlings from a second sowing with improved nursery management reach required minimum size for transplanting faster, they may also be transplanted earlier, which reduces this problem. This same option of early transplanting could allow farmers an extra benefit due to an earlier first harvesting of fruits when they are early adopters of this improved practice.

\subsection{Soil, and not seed, is the major source of seedling contamination}

Tests on the relative contribution of soil and seed as origin of disease problems, i.e. blotter, in vitro and screen house tests, strongly indicated that the soil was the major source for pathogens causing damping-off. Sterilizing the soil with formaldehyde led to significantly higher percentages emergence and healthy seedlings and lower damping-off than sterilizing the seeds with hot water. This indicates farmers' preserved seed might not cause major problems but their nursery soils are the habitat of pathogens and soil treating is most important (Table 4). The laboratory studies also indicated that a wider range of pathogenic genera could be obtained from the soil than from the seeds. 


\section{Chapter 2}

\subsection{Trichoderma harzianum is an effective management option}

The effects of formaldehyde, as proven chemical control of soil pathogens, and T. harzianum were comparable (Table 5) implying the latter is an effective bio control agent. T. harzianum alone seemed to be the major contributor to reducing damping-off and increasing the number of healthy seedlings and seedling quality (Tables 5 and 6). Neither the hot water nor the Carbendazim seed treatment led to a further reduction in damping-off or an increase in number or quality of seedlings when combined with T. harzianum (Table 5 and 6). Although seed treatment with fungicides like Carbendazim and with hot water have been reported to reduce seed-borne pathogens and hot water also enhances germination (Nega et al., 2003), our screen house studies showed that treating seed with hot water or Carbendazim is not as effective as treating soil with $T$. harzianum in improving emergence and reducing post-emergence damping-off (Table 5). These seed treatments neither outperformed T. harzianum in effects on damping-off nor produced any additional effect when combined. T. harzianum has been reported to enhance germination and emergence of various vegetable crops (Chang et al., 1986; Kleifeld and Chet, 1992; Mastouri et al., 2010; Shoresh et al., 2010; Asaduzzaman et al., 2013) and to enhance plant growth, either by promoting the production of growth stimulating factors or the solubilisation of inorganic nutrients and sequestration of inhibitory substances in the soil (Kleifeld and Chet, 1992; Inbar et al., 1994; Harman, 2000; Harman, 2006; Lorito et al., 2010; Shoresh et al., 2010; Harman, 2011; Hermosa et al., 2012).

\subsection{Improved nursery management requires reduction of farmers' conventional sowing density}

While negotiating the first year study with farmers, it became apparent that farmers spray a variety of chemicals of which Carbendazim was a major one to tackle damping-off. Also they indicated to use their preserved seed at high sowing densities to get enough seedlings to transplant despite large damping-off losses. Both protective and curative aspects of treatments were discussed and respectively hot water and T. harzianum were proposed based on literature and on-station research. Farmers could agree on not spraying their nurseries but insisted on testing a chemical seed treatment and jointly Carbendazim was selected because of its availability on the local market and assuming it might not pose any environmental hazards because little active ingredient is needed to treat seeds. Reducing the sowing density to the research derived $2 \mathrm{~g} \mathrm{~m}^{-2}$ turned out to be a major hurdle. In Year 1, farmers accepted this sowing density as the study was performed after their homestead nursery had already been established. But in Year 2, the study was performed at their homesteads so these seedlings were needed to plant their fields. Reducing the sowing densities was only possible for the improved 
management treatments (see also above). The rationale behind the high sowing densities of farmers seems a valid coping strategy to produce enough seedlings for transplanting from the limited land available (i.e. flood free at the end of the rainy season), despite large emergence failure and damping-off losses.

In the participatory studies of both years, the tested improved management included low sowing densities, soil and seed treatment. The net outcome was that despite reducing sowing density enough seedlings could be produced to transplant of which the percentage of good seedlings per plot was much higher (at least 40 percentage points higher) than in the farmers' practice (Tables 1 and 2). Despite broadcasting 4-9 times more seed than in the improved practice, farmers ended up with comparable numbers of seedlings (Table 2) only by including moderate quality seedlings when good quality seedlings were few (50-80\% in improved practice versus $13-18 \%$ in farmers' practice). In designing an IPM strategy it has to be kept in mind that the positive effects of the use of T. harzianum as soil amendment we observed would not be maintained if the sowing densities were increased to what farmers are used to. The enhanced emergence will lead to such high seedling densities that competition will lead to lower quality seedlings (Ross and Harper, 1972; Jurke and Fernando, 2006). Thus the observed effect of the improved management (Figs 1 and 2, Tables 1 and 2) is to be considered as the combined effect of lowered sowing densities and soil and seed treatments rather than only the effect of the soil and seed treatment.

\section{Conclusion}

As single practices often have shortcomings the IPM concept stipulates the need to combine multiple environment-friendly practices to avoid IPM failure (Chandler et al., 2011; Pretty and Bharucha, 2015). Here we would suggest that the minimum combination would be the application of $T$. harzianum to the soil and an adjustment of the sowing density to around $2 \mathrm{~g}$ $\mathrm{m}^{-2}$. Application of formulated T. harzianum would not be difficult to farmers. Moreover, farmers considered the peat-bran formulation of T. harzianum will provide nutrients to the soil. The addition of a hot water treatment can be considered as farmers seemed concerned about treating seeds. However, farmers' training on seed treating needs to be assured. Despite farmers' interest to treat seeds using Carbendazim and the lack of a negative interaction between Carbendazim and T. harzianum here and in other studies (Hu et al., 2016; Bisutti et al., 2017), farmers should not be recommended to use Carbendazim as a seed treatment, because in our study Carbendazim did not show any additional effects when T. harzianum was added to soil 


\section{Chapter 2}

and seeds were treated using hot water, thus the application of a seed treatment with Carbendazim is superfluous and should therefore be discouraged.

To the best of our knowledge this is the first participatory research to combine soil and seed treatments in farmers' conditions and with farmers, while testing the relative effects of such treatments and farmers' seeds and soil under more controlled conditions. This study showed that under farmer conditions the emphasis should clearly be on reducing the effects of soilborne pathogens rather than emphasizing on the importance of seed-borne pathogens. Finally, further work following from this research could be 1) to test the performance of improved seedlings after transplanting in the field in terms of survival of plants, fruit health and crop productivity; 2) to monitor the ability of farmers to sustainably adopt and adapt the improved nursery management once the research is over; 3) to support the local production of $T$. harzianum as soil amendment so that it can become available at village level; 4) to monitor persistence and population level of T. harzianum in nursery soil.

\section{Acknowledgements}

The project was funded by the NUFFIC-NICHE-BGD-156 programme, a collaboration between Wageningen University and Research (WUR) and Bangladesh Agricultural University (BAU). Many thanks to the farmers of Pirijpur for participating in the nursery study and allocating land to tests. Thanks to the farmer trainers for assistance in the nursery study, thanks to the villagers for all sorts of co-operation. Thanks also to the staff of the Plant Bacteriology and Biotechnology Laboratory of BAU for their support in the laboratory studies. We also acknowledge the support of the Seed Pathology Centre and the IPM laboratory of BAU.

\section{References}

Abd-El-Khair, H., Khalifa, R.K.M., Haggag, K.H., 2010. Effect of Trichoderma species on damping off diseases incidence, some plant enzymes activity and nutritional status of bean plants. J. Am. Sci. 6 , 486-497.

Abdul-Baki, A. A., Anderson, J. D., 1973. Vigour determination of soya beans by multiple criteria. Crop Sci. 143, 533- 537.

Al-Askar, A.A., Ghoneem, K.M., Rashad, Y.M., Abdulkhair, W.M., Hafez, E.E., Shabana, Y.M., Baka, Z.A., 2014. Occurrence and distribution of tomato seed-borne mycoflora in Saudi Arabia and its correlation with the climatic variables. Microb. Biotechnol. 7, 556-569.

Asaduzzaman, M., Alam, M.J., Islam, M.M., 2013. Effect of Trichoderma on seed germination and seedling parameters of chili. J. Sci. Found. 8, 141-150. 
Benitez, T., Rincon A.M., Limon., M.C., Codon A.C., 2004. Biocontrol mechanism of Trichoderma strain. Int. Microbiol. 7, 249-260.

Bisutti, I.L., Pelz, J., Büttner, C., Stephan, D., 2017. Field assessment on the influence of RhizoVital® 42 fl. and Trichostar ${ }^{\circledR}$ on strawberries in the presence of soil-borne diseases. Crop Prot. 96, 195203.

Chakraborty, M.R., Chatterjee, N.C., 2008. Control of Fusarium wilt of Solanum melongena by Trichoderma spp. Biol. Plant. 52, 582-586.

Chandler, D., Bailey, A.S., Tatchell, G.M., Davidson, G., Greaves, J., Grant, W.P., 2011. The development, regulation and use of biopesticides for integrated pest management. Philos. Trans. R. Soc., B. 366, 1987-1998.

Chang, Y.C., Chang, Y.C., Baker, R., Kleifeld, O. and Chet, I., 1986. Increased growth of plants in the presence of the biological control agent Trichoderma harzianum. Plant Dis. 70, 145-148.

Dasgupta, M.K., 1988. Principles of Plant Pathology. Allied Publishers Limited, New Delhi, India.

Dasgupta, S., Meisner, C. and Huq, M., 2007. A pinch or a pint? Evidence of pesticide overuse in Bangladesh. J. Agric. Econ. 58, 91-114.

Doni, F., Zain, C.R.C.M., Isahak, A., Fathurrahman, F., Anhar, A., Mohamad, W.N.A.W., Yusoff, W.M.W., Uphoff, N., 2017. A simple, efficient, and farmer-friendly Trichoderma-based biofertilizer evaluated with the SRI rice management system. Org. Agric. (on line only). DOI 10.1007/s13165-017-0185-7.

Dubey, S.C., Bhavani, R., Singh, B., 2011. Integration of soil application and seed treatment formulations of Trichoderma species for management of wet root rot of mungbean caused by Rhizoctonia solani. Pest Manag. Sci. 67, 1163-1168.

Dugan, F.M., 2008. The Identification of Fungi: An Illustrated Introduction With Keys, Glossary and Guide to Literature, Second ed. APS. Press, St. Paul. Minnesota, USA.

Ecobichon, D.J., 2001. Pesticide use in developing countries. Toxicology. 160, 27-33.

Fernando, W.G.D., Nakkeeran, S., Zhang, Y., Savchuk, S., 2007. Biological control of Sclerotinia sclerotiorum (Lib.) de Bary by Pseudomonas and Bacillus species on canola petals. Crop Prot. 26, 100-107.

Gautam, S., Schreinemachers, P., Uddin, M.N., Srinivasan, R., 2017. Impact of training vegetable farmers in Bangladesh in integrated pest management (IPM). Crop Prot. 102, 161-169.

Gerhardson, B., 2002. Biological substitute for pesticides. Trends Biotechnol. 20, 338-343.

Gupta, V.K., Paul, Y.S., 2001. Fungal diseases of tomato, chilli and brinjal. Diseases of Vegetable Crops. Kalyani Publishers, Ludhiana, India.

Harman G.E., 2000. Myths and dogmas of biocontrol changes in perceptions derived on Trichoderma harzianum T-22. Plant Dis. 84, 377-393. 


\section{Chapter 2}

Harman, G.E., 2006. Overview of mechanisms and uses of Trichoderma spp. Phytopathology 96, 190194.

Harman, G.E., 2011. Trichoderma — not just for biocontrol anymore. Phytoparasitica 39, 103-108.

Harman G.E., Howell, C.R., Viterbo, A., Chet, I., Lorito, M., 2004. Trichoderma species - opportunistic, avirulent plant symbionts. Nat. Rev. Microbiol. 2, 43-56.

Hermosa, R., Viterbo, A., Chet, I. and Monte, E., 2012. Plant-beneficial effects of Trichoderma and of its genes. Microbiology 158, 17-25.

Howell, C. R., 2006. Understanding the mechanism employed by Trichoderma virens to effect biological control of cotton diseases. Phytopathology 96, 178-180.

Hu, X., Roberts, D.P., Xie, L., Yu, C., Li, Y., Qin, L., Hu, L., Zhang, Y., Liao, X., 2016. Use of formulated Trichoderma sp. Tri-1 in combination with reduced rates of chemical pesticide for control of Sclerotinia sclerotiorum on oilseed rape. Crop Prot. 79, 124-127.

Inbar, J., Abramsky, M., Cohen, D. and Chet, I., 1994. Plant growth enhancement and disease control by Trichoderma harzianum in vegetable seedlings grown under commercial conditions. Eur. J. Plant Pathol. 100, 337-346.

Islam M.R., Meah, M.B., 2011. Association of Phomopsis vexans with eggplant (Solanum melongena) seeds, seedlings and its management. The Agric. 9, 8-17.

ISTA (International Seed Testing Association)., 2017. Seed Health Testing Methods. International Rules for Seed Testing, Introduction, i-I-6 (12)

Jurke C.J., Fernando, W.G.D., 2006. Effects of seeding rate and plant density on Sclerotinia stem rot incidence in canola. Nature 444, 323-329.

Kapoor, A.S., 2008. Biocontrol potential of Trichoderma spp. against important soil borne diseases of vegetable crops. Indian Phytopathol. 61, 492-498.

Keinath, A.P. and Farnham, M.W., 2001. Effect of wire stem severity on survival and head production of transplanted broccoli and cabbage. Plant Dis. 85, 639-643.

Kleifeld, O. and Chet, I., 1992. Trichoderma harzianum - interaction with plants and effect on growth response. Plant Soil 144, 267-272.

Laemmlen, F., 2001. Damping-off diseases. University of California, ANR Publication. 8041. UC, Davis, California.

Lamichhane, J.R., Dürr, C., Schwanck, A.A., Robin, M.H., Sarthou, J.P., Cellier, V., Messéan, A. and Aubertot, J.N., 2017. Integrated management of damping-off diseases. A review. Agron. Sustainable Dev. 37, 10. DOI 10.1007/s13593-017-0417 y.

Lawrence, W.J.C., 1956. Soil sterilization. George Allen and Unwin Limited, London, UK.

Lorito, M., Woo, S. L., Harman, G. E., \& Monte, E., 2010. Translational research on Trichoderma: from proteomics to the field. Annu. Rev. Phytopathol. 48, 395-417. 
Mancini, V., Romanazzi, G., 2013. Seed treatments to control seed-borne fungal pathogens of vegetable crops. Pest Manag. Sci. 70, 860-868.

Mastouri, F., Björkman, T., Harman, G.E., 2010. Seed treatment with Trichoderma harzianum alleviates biotic, abiotic, and physiological stresses in germinating seeds and seedlings. Phytopathology 100, 1213-1221.

Meah, M.B., 2003. Hot water seed treating machine. IPM Lab, Bangladesh Agricultural University, Mymensingh. Bangladesh.

Meah, M.B., 2007. Biopesticide. IPM Lab, Bangladesh Agricultural University, Mymensingh. Bangladesh.

Menzies, J.D., 1963. Survival of microbial plant pathogens in soil. Bot. Rev. 29, 79-122.

Mia, M.Y., Hossain, M.S., Karim, A.N.M.R., 2016. Integrated pest management of vegetable crops in Bangladesh.In: Muniappan, R. and Heinrichs, E.A. (Eds), Integrated pest management of tropical vegetable crops. Springer, Dordrecht, The Netherlands, pp. 235-249.

Molla, A.H., Haque, M.M., Haaque, M.A., Ilias, G.N.M., 2012. Trichoderma-enriched biofertilizer enhances production and nutritional quality of Tomato (Lycopersicon esculentum Mill.) and minimizes NPK fertilizer use. Agric. Res. 1, 265-272.

Morse, S., 2009. IPM, ideals and realities in developing countries. In: Radcliffe, E.B., Hutchinson,W.D., Cancelado, R.E. (Eds), Integrated Pest Management, Concepts, Tactics, Strategies and Case Studies. Cambridge University Press, Cambridge, UK, pp. 458-470.

Morse, S., Buhler, W.,1997. IPM in developing countries: the danger of an ideal. Integra. Pest Manag. Rev. 2, 175-185.

Muthukumar, A., Eswaran, A., Nakkeeran, S., Sangeetha, G., 2010. Efficacy of plant extracts and biocontrol agents against Pythium aphanidermatum inciting chilli damping-off. Crop Prot. 29, 1483-1488.

Narayanasamy, P., 2013. Cultural practices influencing biological management of crop diseases, In: Narayanasamy, P., (Ed.) Biological management of diseases of crops. Springer, Dordrecht, Netherlands. pp. 9-56.

Nega, E., Ulrich, R., Werner, S., Jahn, M., 2003. Hot water treatment of vegetable seed an alternative seed treatment method to control seed borne pathogens in organic farming. J. Plant Dis. Prot. 110, 220-234.

Pagoch, K., Srivastava, J.N., Singh, A.K., 2015. Damping-off diseases of seedlings in Solanaceous vegetables: current status and disease management. In: Awasthi , L.P. (Ed.), Recent advances in the diagnosis and management of plant diseases. Springer, India, pp. 35-46.

Parsa, S., Morse, S., Bonifacio, A., Chancellor, T.C., Condori, B., Crespo-Pérez, V., Hobbs, S.L., Kroschel, J., Ba, M.N., Rebaudo, F. and Sherwood, S.G., 2014. Obstacles to integrated pest management adoption in developing countries. Proc. Natl. Acad. Sci. 111, 3889-3894.

Pingali, P.L., 1995. Impact of pesticides on farmer health and the rice environment: an overview of results from a multidisciplinary study in the Philippines. In: Pingali, P.L., Roger, P.A. (Eds), Impact 


\section{Chapter 2}

of pesticides on farmers health and the rice environment. Springer, Dordrecht, Netherlands, pp. 321.

Prasad, R.D., Rangeshwaran, R., Anuroop, C.P. and Rashmi H.J., 2002. Biological control of wilt and root rot of chickpea under field conditions. Ann. Plant Prot. Sci. 1, 72-75.

Pretty, J., Pervez Bharucha, Z., 2015. Integrated pest management for sustainable intensification of agriculture in Asia and Africa. Insects 6, 152-182.

Read, J., Stokes, A., 2006. Plant biomechanics in an ecological context. American Journal of Botany 93, 1546-1565.

Ross, M.A. and Harper, J.L., 1972. Occupation of biological space during seedling establishment. J. Ecol. 60, 77-88.

Schreinemachers, P., Wu, M.H., Uddin, M.N., Ahmad, S. and Hanson, P., 2016. Farmer training in offseason vegetables: Effects on income and pesticide use in Bangladesh. Food Policy 61, 132-140.

Sharma, N., Razdan, V.K., 2012. Perpetuation of Phomopsis vexans on infected seeds, leaf and fruit parts of Solanum melongena L (Brinjal). VEGETOS: Int. J. Plant Res. 25, 196-202.

Shoresh, M., Mastouri, F., \& Harman, G. E., 2010. Induced systemic resistance and plant responses to fungal biocontrol agents. Ann. Rev. Phytopathol. 48, 21-43.

Singh, R.S., 1992. Diseases of Vegetable Crops. Oxford and IBH Publishing Company Private Limited, New Delhi, Bombay, Calcutta, India.

Singh, R.P., 1995. Plant Pathology. Central book depot, Allahabad, India.

Somda, I., Sanou, J., Sanon, P., 2008. Seed borne infection of farmers saved maize seed by pathogenic fungi and their transmission to seedling. Plant Pathol. J. 7, 98-103.

Tjamos, E.C., Papavizas, G.C., Cook, R.J., 1992. Biological control of plant agents and other soil-borne pathogens. Ph.D. thesis. Texas A\&M University, College Station, Texas.

Uddin, M.M., Akhtar, N., Islam, M.T., Faruq, A.N., 2009. Effect of Trichoderma harzianum and some selected soil amendments on damping-off disease of eggplant and tomato. J. Sci. Found. 7, 117 126.

Van Mourik, T.A., Stomph, T.J., Murdoch, A.J., 2005. Why high seed densities within buried mesh bags may overestimate depletion rates of soil seed banks. J. Appl. Ecol. 42, 299-305.

Verma, M., Brar, S.K., Tyagi, R.D., Surampalli, R.Y. and Valero, J.R., 2007. Antagonistic fungi, Trichoderma spp.: panoply of biological control. Biochem. Eng. J. 37, 1-20.

Watanabe,T., 1994. Pictorial Atlas of soil and seed fungi. Lewis Publishers, Boca Raton, Florida.

Yedidia, I., Srivastva, A.K., Kapulnik, Y. and Chet, I., 2001. Effect of Trichoderma harzianum on microelement concentrations and increased growth of cucumber plants. Plant and Soil 235, 235242 


\section{CHAPTER 3}

Disease management in eggplant (Solanum melongena L.) nurseries also reduces wilt and fruit rot in subsequent plantings: A participatory testing in Bangladesh

Naznin Nahar ${ }^{\mathrm{a}, \mathrm{b}}$, Md. Rashidul Islam ${ }^{\mathrm{a}}$, Mohammad Mahir Uddin ${ }^{\mathrm{a}}$, Peter de Jong ${ }^{\mathrm{b}}$, Paul C.

Struik $^{b}$, Tjeerd-Jan Stomph ${ }^{b}$

${ }^{\text {a }}$ Faculty of Agriculture, Bangladesh Agricultural University (BAU), Mymensingh-2202,

Bangladesh

${ }^{\mathrm{b}}$ Department of Plant Sciences, Wageningen University and Research Centre (WUR), 6708

PB Wageningen, The Netherlands

Published as: Nahar, N., Islam, M. R., Uddin, M. M., de Jong, P., Struik, P. C. and Stomph, T. J., 2019. Disease management in eggplant (Solanum melongena L.) nurseries also reduces wilt and fruit rot in subsequent plantings: A participatory testing in Bangladesh. Crop Protection, 120: 113-124. https://doi.org/10.1016/j.cropro.2019.02.018 


\section{Chapter 3}

\section{Abstract}

Bacterial wilt (causal agent: Ralstonia solanacearum) and Phomopsis fruit rot (causal agent: Phomopsis vexans) are two major diseases constraining eggplant production in Bangladesh. No integrated management options to manage both diseases together are currently available; farmers spray pesticides. A 2-year participatory study was conducted to compare yield and disease severity of plants that originated from preceding nursery studies. Both soil and seed were found to be source of these pathogens. Seedlings raised according to farmers' practice or in nursery soil treated with Trichoderma harzianum from seed treated either with hot water or Carbendazim were transplanted on fields either with or without soil application of T. harzianum. The seed treatments had comparable effects. Improved nursery management alone reduced wilt and fruit rot by 25-40 and 14-20 percentage points respectively, increased marketable yield by 8-19 $\mathrm{t} \mathrm{ha}^{-1}$ and income by $€ 1800-3700 \mathrm{ha}^{-1}$ compared to farmers' conventional practice of spraying. In Year 1, a comparable result was obtained treating only the field but not the nursery; farmers, however, did not want to repeat this treatment in Year 2 as costs were higher. Further disease reduction (10-11 and 0.6-6 percentage points respectively for wilt and rot) occurred when improved seedlings were transplanted into $T$. harzianum amended fields and consequently marketable yield increased by $5-7 \mathrm{t} \mathrm{ha}^{-1}$ and income by $€ 500-900 \mathrm{ha}^{-1}$. Both labour and material costs of the introduced technology were lower than the costs of current farmers' practice. Given costs of labour and inputs and eggplant price fluctuations over years, farmers are recommended to use the improved nursery management practices. Also treating the field may depend on the capacity of farmers to invest in the additional labour and input. In fields with improved management, T. harzianum persisted at the end of the growing season and reduced populations of $R$. solanacearum and $P$. vexans. Also, seed preserved from improved management plots showed reduction of both pathogens compared to seed from farmers' practice plots. The reduction of pathogens both in field soil and preserved seed for improved management plots may imply that a next crop will start with a lower level of disease pressure. Laboratory tests showed nursery raised seedlings from screenhouse experiments were always found infected with $R$. solanacearum, but soil application of $T$. harzianum alone or combined with hot water treatment of seed substantially reduced the infection. Given the positive results of our study, the technology should be made locally available to support eggplant IPM.

Keywords: Integrated pest management, Phomopsis vexans, Ralstonia solanacearum, Soil treatment, Trichoderma harzianum, Seed treatment 


\section{Introduction}

Eggplant (Solanum melongena L.) is one of the most important vegetable crops of Bangladesh. Growing eggplant strongly enhances the livelihoods of small-holders because it can be harvested and sold weekly. However, sustainable production is greatly constrained by various diseases each year, of which damping-off in the nursery (different causal agents), bacterial wilt (causal agent Ralstonia solanacearum) and fungal fruit rot (causal agent Phomopsis vexans) in the field are most important (Ramesh, 2008; Singh et al., 2014; Pagoch et al., 2015).

In the nursery, damping-off appears within a week after emergence and continues for another week reaching a severity up to $80 \%$. This disease is caused by various soil and seed fungi ultimately resulting in a poor stand of less vigorous seedlings (Nahar et al.2018). In the field, bacterial wilt has been reported to be the most destructive disease with a severity of 1090\% (Ramesh, 2008; Vanitha et al., 2009; Nishat et al., 2015). Wilt may appear soon after transplanting and continues up to fruiting or even final harvest. Farmers often face substantial plant losses before fruiting resulting in severe economic losses. Ralstonia solanacearum generally invades plant roots from the soil through root injury or any natural openings to colonize the vascular system thus blocking translocation of water and nutrients. Consequently, wilt starts in the upper leaves followed by complete plant loss within a few days. Soil is the main source of infection of wilt; however, seeds and seedlings may also carry the pathogen (Ramesh, 2008; Vanitha et al., 2009; Tahat and Sijam 2010; Sharma and Sharma, 2014).

After fruiting, Phomopsis fruit rot causes yield losses of 15-50\% (Jayaramaiah et al., 2013; Mahadevkumar and Janardana, 2016). It starts as a pale, sunken, oval depression on the fruit followed by complete rot and mummification. Seed is the main infection source of fruit rot; however, P. vexans also persists in plant debris and in soil (Panwar et al., 1970; Vishunavat and Kumar,1994; Islam and Meah, 2011; Sharma and Razdan, 2012).

Apart from seed and field soil, transplanted seedlings might be one of the crucial sources of disease development and spread in the field. Seedlings surviving damping-off in the nursery most likely carry-over pathogens to the main field. Moreover, such seedlings are prone to disease infection in the field because they are weak. Leaving rotten fruits and infected plants in the field is common practice of farmers in the study area (personal observation NN). Hence, field soil could also be a source of infection for both diseases. Therefore, transplanting healthy and vigorous seedlings as well as treating field soil might help to control wilt and fruit rot, thus improving yield and economic return to farmers (Ratha Krishnan et al., 2014; Lin et al., 2015). 


\section{Chapter 3}

In the current system, soil amendment with the biocontrol agent Trichoderma harzianum might be a good strategy. Trichoderma spp. have been well-documented to control a wide range of soil- and seed-borne pathogens (Harman, 2000; Harman, 2006; Dubey et al., 2011; Kulkarni, 2015) including P. vexans (Srinivas et al., 2005; Ghosh, 2017) and R. solanacearum (Yendyo et al., 2017; Konappa et al., 2018). Trichoderma spp. are also known to enhance plant growth and productivity (Harman, 2000; Shoresh et al., 2010). However, the success of controlling disease organisms depends on survival and activity of Trichoderma spp. in the field throughout the cropping season (Longa et al., 2009). Main mechanisms that are deployed by Trichoderma spp. are antagonism, mycoparasitism, competition with pathogens for nutrient and space, and induction of systemic resistance in plants (Yedidia et al., 2001; Benitez et al., 2004; Harman et al., 2004; Howell, 2006; Hermosa et al., 2012).

Pesticides are the major means of disease control for eggplant farmers in Bangladesh (Ecobichon, 2001; Gautam et al., 2017; Schreinemachers et al., 2017). Daily spraying of cocktails of pesticides has been reported (Rashid et al., 2003; Bentley, 2009). Improper use of pesticides has led to residue accumulation on eggplants (Chowdhury et al., 2013). This made importing countries to consider restrictions on vegetables, especially eggplants from Bangladesh (Rahman, 2016). Moreover, pesticides threaten farmers' health and environment and lead to resistance development of pathogens against pesticides while they also impact nontarget and beneficial organisms (Pingali, 1995; Rahman and Alam, 1997; Dasgupta et al., 2005; Dasgupta et al., 2007; Aktar et al., 2009; Ma et al., 2009; Miah et al., 2014). Therefore, eggplant growers of Bangladesh require alternatives to pesticides.

To manage bacterial wilt of eggplant, multiple measures such as use of resistant cultivars, grafting seedlings with wild rootstock, crop rotation, soil fumigation, and chemical controls have been recommended. However, all those measures have limited success and adoption because they are difficult to apply under farmers' condition (Vanitha et al., 2009; Rahman et al., 2010; Islam et al., 2014). An integrated approach based on seed treatment with hot water, botanicals and T. harzianum and soil treatment with T. harzianum to control Phomopsis fruit rot has been suggested, but participatory testing in farmers' field is still required (Islam, 2005). To the best of our knowledge, IPM-based management approaches for the combination of bacterial wilt and fungal fruit rot for eggplant have neither been developed nor jointly tested with farmers. Particular control measures for each disease would not only be difficult for smallholder farmers to implement but will also be expensive. Therefore, a sustainable disease management approach for eggplants should be developed in collaboration with farmers. Indeed, 
farmers' participation in experimentation allows much better than on-station research to assess what is achievable under farmers' conditions rather than what is technically perfect (Morse and Buhler, 1997; Morse, 2009; Parsa et al., 2014).

In a preceding nursery study with farmers, we produced more healthy and vigorous seedlings treating soil with T. harzianum and seed either with hot water or Carbendazim compared to farmers' practice (Nahar et al., 2018). In the present study, we transplanted improved seedlings with or without field soil treatment with T. harzianum and conducted additional supporting laboratory and screenhouse studies. We thus tested the following hypotheses: 1) transplants from improved nurseries will show smaller losses by wilt and rot and thus yield more, 2) transplants will carry less latent $R$. solanacearum infection, 3) an additional field application will further reduce wilt and rot levels and improve yield, 4) T. harzianum will be transferred with seedlings and will remain present throughout the season, 5) levels of target pathogens and non-target fungi in the field soil will be reduced, 6) pathogen (bacterial and fungal) incidence in seed preserved from experimental fields will be reduced, and, finally, 7) the treatments will provide farmers with an economically sound alternative for their disease management.

\section{Materials and Methods}

\subsection{Study site}

A two-year participatory study was carried out in Pirijpur village $\left(25^{\circ} 02^{\prime} 13^{\prime \prime} \mathrm{N}-89^{\circ} 50^{\prime} 08^{\prime \prime} \mathrm{E}\right)$, Jamalpur district, Bangladesh. Jamalpur district is the major eggplant growing area of Bangladesh. Farmers cultivate eggplants during the cool dry season (Rabi season: SeptemberMarch). The study was conducted in two consecutive Rabi seasons.

\subsection{Participatory field study}

\subsubsection{Study in Year 1}

The study was laid-out as split-plot design using seven farmers' fields as replicates. All fields had a history of bacterial wilt and fruit rot disease. Each field was divided into two main plots: one plot was amended with T. harzianum, the other one not. Each main plot was divided into three sub-plots to transplant differentially treated seedlings from a preceding participatory nursery study (Nahar et al., 2018) . Thus six treatments were tested: (i) Improved nursery practice 1 (nursery soil treated with $T$. harzianum and seed with hot water) combined with field soil application of T. harzianum; (ii) Improved nursery practice 2 (nursery soil treated with $T$. harzianum and seed with Carbendazim) combined with field soil application of T. harzianum; (iii) Farmers' conventional nursery practice (no soil and seed treatment but spraying on 


\section{Chapter 3}

appearance of damping-off) combined with field soil application of T. harzianum; (iv) Only improved nursery practice 1; (v) Only improved nursery practice 2; (vi) Farmers' conventional practice (spraying after disease appearance in both nursery and field). Depending on the land availability, plot size differed among farmers with a maximum sub-plot size of $15 \times 7 \mathrm{~m}$ and a minimum sub-plot size of $7 \times 5 \mathrm{~m}$. Cultured $T$. harzianum suspension was obtained from the Bangladesh Agricultural University IPM laboratory (BAU-IPM); $25 \mathrm{~mL}$ of the suspension containing $12 \times 10^{6} \mathrm{CFU} / \mathrm{mL}$ was added per $\mathrm{kg}$ of a $1 / 1$ mixture of peat soil and black gram (Vigna mungo (L.) Hepper) bran. Some 7-10 days before transplanting, $10 \mathrm{~g} \mathrm{~m}^{-2}$ of the mixture was applied to the already tilled soil and incorporated into the top $10 \mathrm{~cm}$ by another tillage or spading. Seedlings aged $34-35$ days were transplanted at $0.7 \times 0.7 \mathrm{~m}$ spacing. Two main plots were separated by at least $2 \mathrm{~m}$ and each sub-plot was separated by a bund of $0.5 \mathrm{~m}$. Fertilizer application, irrigation and weeding were done as per farmer's standard practice. In the farmers' conventional plots, farmers sprayed pesticide (Carbendazim) at 10-15 days intervals throughout the season.

Plots were monitored regularly, excluding two border rows, to observe the onset of wilt and incidence was recorded weekly by counting wilted and healthy plants from onset to stabilization. A plant was considered wilted when a single branch or the whole plant showed leaf drooping or wilting and tagged to avoid repeated counting in the next observation; actual decision of removal was left to each farmer. From these observations, cumulative percent incidence of wilt over time was calculated. On fruiting, plots were monitored for onset of fruit rot. Fruit rot data were taken weekly from onset of rotting until farmers stopped harvesting. Eggplants with typical rot symptoms (pale, sunken, depressed, circular lesion) were plucked, counted and discarded from the field. Healthy eggplants were harvested and counted. Counts of healthy and rotten fruits were converted into weights based on average fruit weights established on subsamples. From these data, percent cumulative fruit rot over time was determined. Finally, total marketable yield accounting for both wilt and rot was calculated and expressed as $\mathrm{tha}^{-1}$. Yield losses $\left(\mathrm{t} \mathrm{ha}^{-1}\right)$ attributed to wilt and fruit rot were estimated. At every harvest the average per plant yield of surviving plants was multiplied with the number of plants lost to wilt at that moment as estimated loss to wilt. Loss to fruit rot was estimated at each harvest as the number of fruits lost to rot multiplied by the average weight of harvested healthy fruits. Both losses were cumulated over the season. To assess the economic benefit of the treatments, expenses of inputs and labour involving crop protection and agronomic practices 
were recorded per farmer. Price of eggplants was also recorded throughout the season. Ultimately, income from each practice was calculated.

\subsubsection{Study in Year 2}

Nine farmers participated and transplanted seedlings from the participatory nursery study of Year 2. The study was designed as randomized complete block design using each farmer as block. Each farmer tested three treatments: (i) Improved nursery practice combined with field soil application of T. harzianum; (ii) Improved nursery practice only; (iii) Farmers' conventional nursery practice combined with their field practice. Five farmers opted for testing nursery practice 1 and four farmers tested practice 2 (see Section 2.2.1). Application of $T$. harzianum in field soil was done as mentioned in Section 2.2.1. Each farmer maintained three plots of $10 \times 10 \mathrm{~m}$ maintaining plot to plot and farmer to farmer distances of at least $10 \mathrm{~m}$. Again a bund of $0.5 \mathrm{~m}$ was constructed to demark each plot and avoid contamination. From each plot, observation was taken from an area of $4 \times 4 \mathrm{~m}$; plant spacing was $0.65 \times 0.65 \mathrm{~m}$ but varied slightly among farmers. Initial plant number per plot was counted. Then incidence of wilt and fruit rot and marketable yield were recorded weekly as in Year 1 (see 2.2.1). Cost of implementing each treatment and price of eggplants were also recorded.

At 170 days after transplanting (DAT) when farmers' had stopped harvesting, to evaluate the influence of improved managements on plant growth, five random plants from each plot were uprooted by loosening soil carefully to measure root length, shoot length, stem diameter at base, number of branches and lateral roots. Farmers' evaluation of plant growth was also recorded. Farmers anonymously scored each other's plants based on the following criteria: plant height, root length, stem diameter, branch number, leaf colour on 3-point scale (1=poor, $2=$ moderate, $3=$ good). Farmers also evaluated each other's field based on overall appearance and harvest of eggplant fruits.

\subsection{Surveying prevalence of bacterial wilt}

In three consecutive seasons (2015-2016: exploratory study; 2016-2017: participatory study Year 1; 2017-2018: participatory study Year 2) surveys were conducted to determine the prevalence of bacterial wilt across eggplant fields in the study village. Plants from 15 randomly selected farmer's fields, excluding experimental fields, were inspected at various crop stages viz. few days after transplanting (20 DAT), at flowering (60 DAT), fruiting (100 DAT) and towards the end of the season (150 DAT). Selected fields were at least $800 \mathrm{~m}^{2}$. From each field, six subplots of 20 plants each were sampled in a zig-zag patterns along a diagonal transect 


\section{Chapter 3}

through each field to record percent incidence of wilt. Plants were scored as wilted when showing the typical symptoms of bacterial wilt viz. leaf drooping, wilting, oozing and vascular browning.

\subsection{Laboratory and screenhouse studies}

2.4.1. Persistence of T. harzianum in the experimental fields and its influence on P. vexans, non-target fungi and $R$. solanacearum

Soil samples were taken from all plots on all experimental fields of nine farmers of the Year 2 study. Per plot a pooled sample was made from five soil cores taken randomly from the top 10 to $15 \mathrm{~cm}$ near to a plant at the end of the season (175 DAT) when farmers stopped harvesting but plants were still in the field. Pooled samples were carefully transferred to sterile plastic bags and transported to the laboratory within 24 hours of collection. In the lab, samples were airdried for 5 days, sifted with a $2 \mathrm{~mm}$ mesh sieve and stored for less than a month at $4{ }^{\circ} \mathrm{C}$ until testing. To confirm the presence of T. harzianum and its influence on target pathogens Ralstonia solanacearum and Phomopsis vexans and non-target mycoflora, $1 \mathrm{~g}$ of soil was added to $10 \mathrm{~mL}$ of double distilled water, vortexed for $30 \mathrm{~s}$, then shaken for $15 \mathrm{~min}$ and serially diluted from $10^{-1}$ to $10^{-4}$. One $\mathrm{mL}$ of the $10^{-4}$ dilution was spread to each of four sterile Petri dishes with PDA (potato dextrose agar) media supplemented with streptomycin per soil sample to get reasonable count of colony forming unit (CFU). The Petri dishes were incubated at $28 \pm 2{ }^{\circ} \mathrm{C}$ for 7 days. After incubation, CFU of T. harzianum, native Trichoderma spp. if any appeared and any other fungal genera including Phomopsis vexans were counted based on their distinctive colony morphology. For further confirmation, all representative fungi colonies were subjected to purification and identified macroscopically by colony colour and morphology and microscopically by morphological keys (Watanabe, 1994; Dugan, 2008). To confirm the applied $T$. harzianum colonies, it was compared macroscopically and microscopically with source T. harzianum of the BAU-IPM laboratory. Applied T. harzianum was distinguished from native Trichoderma spp. by its characteristic colony morphology (whitish green to pale green colour with effuse conidiation). For further confirmation, all representative Trichoderma colonies were subjected to purification by sub-culturing. T. harzianum was identified macroscopically by colony colour and morphology and microscopically by morphological keys (arrangement of conidiophores, phialides and conidia) according to Rifai (1969). Trichoderma colonies other than applied T. harzianum were not identified at species level and were termed "native Trichoderma spp." After counting each fungal population they were expressed as CFU $\mathrm{g}^{-1}$ of soil. 
To test the abundance of $R$. solanacearum in soil from study plots, $50 \mu \mathrm{L}$ of the $10^{-4}$ dilution was spread on each of four sterile TTC (Triphenyl Tetrazolium Chloride) media plates. Plates were incubated at $28 \pm 2{ }^{\circ} \mathrm{C}$ for 48 hours. After incubation, both virulent (white fluidal with pink centres ) and non-virulent (dark red) colonies from each replicate were counted and expressed as CFU g ${ }^{-1}$ of soil.

2.4.2. Incidence of $R$. solanacearum, $P$. vexans and T. harzianum in seeds produced in the Year 2 study

Five random mature fruit from five random plants of each experimental plot (see 2.2.2) of nine farmers were selected to preserve seed from the Year 2 study. Farmers prepared the seed separately according to their standard procedure under the monitoring of a field research assistant. Seeds of five fruits per treatment and replicate were pooled, brought to the laboratory and plated on TTC media to screen for $R$. solanacearum and on PDA medium to screen for $P$. vexans and T. harzianum. Before plating, seeds were surface sterilized with $1 \%$ sodium hypochlorite $(\mathrm{NaOCl})$ solution followed by three repeated washings with distilled water and blot-dried. Per seed sample, 100 seeds were aseptically and evenly distributed over four replicates of 25 seeds. Plates were then incubated at $28 \pm 2{ }^{\circ} \mathrm{C}$. After 48 hours of incubation, seeds with virulent and non-virulent $R$. solanacearum colonies were counted. After a week of incubation, seeds with $P$. vexans or T. harzianum colonies were counted. Prevalence of hosted pathogens or T. harzianum was expressed as a percentage of number of tested seeds.

\subsubsection{Sources of infection of $R$. solanacearum and $P$. vexans}

To determine the sources of infection of both pathogens, seeds were obtained from seven farmers and soil was collected from their fields prior to the Year 1 study. Seeds were screened to detect $R$. solanacearum and P. vexans by plating them onto TTC and PDA medium, respectively, according to the methodology described in Section 2.4.2. Soil was serially diluted and plated on respective media for $R$. solanacearum and P. vexans as described in Section 2.4.1.

Seedlings from eight lots of farmers' seed (seven farmers who participated in the Year 1 study and one additional farmer from the village) were raised in eight trays $(0.3 \times 0.2 \mathrm{~m})$ filled with $4 \mathrm{~kg}$ of soil originated from highly contaminated field of one of the farmers. Per tray, 100 seeds were placed in 4 rows of 25 seeds. After two weeks of emergence, 10 apparently healthy seedlings were randomly picked per tray taking at least two from each row and brought to the laboratory for further testing to assess whether any latent seedling infection by $R$. solanacearum occurred (see Section 2.4.4. below). Seedlings were not tested for P. vexans. 


\section{Chapter 3}

\subsubsection{Effect of soil treatment with T. harzianum alone or combined with seed treatment with}

hot water on $R$. solanacearum infection of seedlings

In the screenhouse, a randomized complete block design in five replicates was carried out with three treatments: i) soil treated with $T$. harzianum and seed with hot water; ii) soil treated with T. harzianum only; and iii) farmers' control (no soil and no seed treatment). The most infected seed lot as established in Section 2.4.3 and highly infected soil from one of the farmer's field were used in this experiment. Aseptic trays $(0.3 \times 0.2 \mathrm{~m})$ were filled with $4 \mathrm{~kg}$ of soil. $T$. harzianum was mixed with soil at $1 \mathrm{~g}$ per tray, based on the formulation described in Section 2.2.1, 10 days before sowing. Hot water treatment of seed was done according to Nahar et al. (2018). Per tray, 100 seeds were placed in 4 rows of 25 seeds. After emergence, incidence of bacterial wilt was monitored every alternate day during three weeks. As none of the seedlings of any treatments showed wilt symptoms, seedlings were tested in the laboratory for latent infections. Per treatment, ten random seedlings per replicate were uprooted and tested in the laboratory. A part of the stem was cut from each seedling and surface sterilized by $70 \%$ ethanol. The stem part of each seedling was then soaked overnight in an Eppendorf tube containing 1 $\mathrm{mL}$ of sterilized water. The next day, water from each tube was streaked on Petri dishes containing TTC media and dishes were incubated at $28 \pm 2{ }^{\circ} \mathrm{C}$ for 48 hours. After incubation, the number of seedlings (per treatment per replicate) that developed either virulent or nonvirulent colonies was counted.

\subsection{Statistical analyses}

Data of all experiments were subjected to ANOVA following the respective designs by statistical package RX64 version 3.2.0 and Genstat 19th ed. Residuals were checked for normality and homogeneity respectively with Shapiro-Wilk and Bartlett's tests. The Bonferroni post-hoc test was used for mean separation. Results of all statistical testing is reported in the tables, readers are referred to these to check on p-values related to effects reported as significant in the text.

\section{Results}

Molecular analysis identified all the bacteria that were isolated from seed and soil samples obtained from participating farmers and from seedlings raised from these as $R$. solanacearum (Appendix Fig. A1). We therefore surmised that the observed bacterial wilt was caused by $R$. solanacearum. 


\subsection{Reduced bacterial wilt and Phomopsis fruit rot and increased marketable yield under} improved management

In Year 1, the two-way interactions between nursery and field treatments with T. harzianum on percentage plants lost to bacterial wilt, percentage fruits lost to $P$. vexans, and loss attributed to fruit rot were significant (Table 1). For yield loss attributed to wilt and marketable yield, this interaction was not observed. The improved nursery practices alone significantly reduced the diseases and the losses attributed to either of them and increased the marketable yield. The main effect of treating the field with $T$. harzianum was a further reduction in losses attributed to wilt and an increase in marketable yield. Treating the field also reduced percentage plants lost to wilt and percentage fruits lost to rot and estimated yield loss to rot and this was stronger when the nursery had not been treated. No differences were observed in the effects of the two seed treatments in either year on disease severity, marketable yield and loss attributed to wilt or rot.

In Year 2, the analysis showed neither interaction $(P>0.15)$ between the two improved nursery management practices and the application of $T$. harzianum to the field nor a difference $(P>0.25)$ between the seed treatments for any of the observed variables. For further analyses, the two seed treatments were therefore considered a single treatment and the comparison reported here is between treating seeds and nursery soil followed by either field application of T. harzianum or not and as third treatment farmers' conventional practices in the nursery and field. Improved nursery management proved always a significant improvement compared with the conventional practices, so fewer plants and fruits were lost due to wilt and rot, respectively, the marketable yield was higher and the yield losses due to wilt and rot were lower (Table 1). The addition of $T$. harzianum in the field after the improved nursery management led to a significant increase in marketable yield and fewer plants lost to wilt than when the field was not amended, but there were no differences for percentage fruits lost to rot or yield loss attributable to fruit rot or wilt.

In Year 1, a comparable reduction was obtained by only treating the field soil or only treating the seed and nursery soil (Table 1). On discussing results with farmers after the first year, they concluded not to repeat the field only treatment in Year 2 as this reached the same results but demanded more work and inputs. 


\section{Chapter 3}

Table 1. Percentage plants lost to bacterial wilt or to Phomopsis fruit rot, marketable eggplant yield and estimated yield losses to wilt and rot from farmers' fields treated with various combinations of nursery and field management.

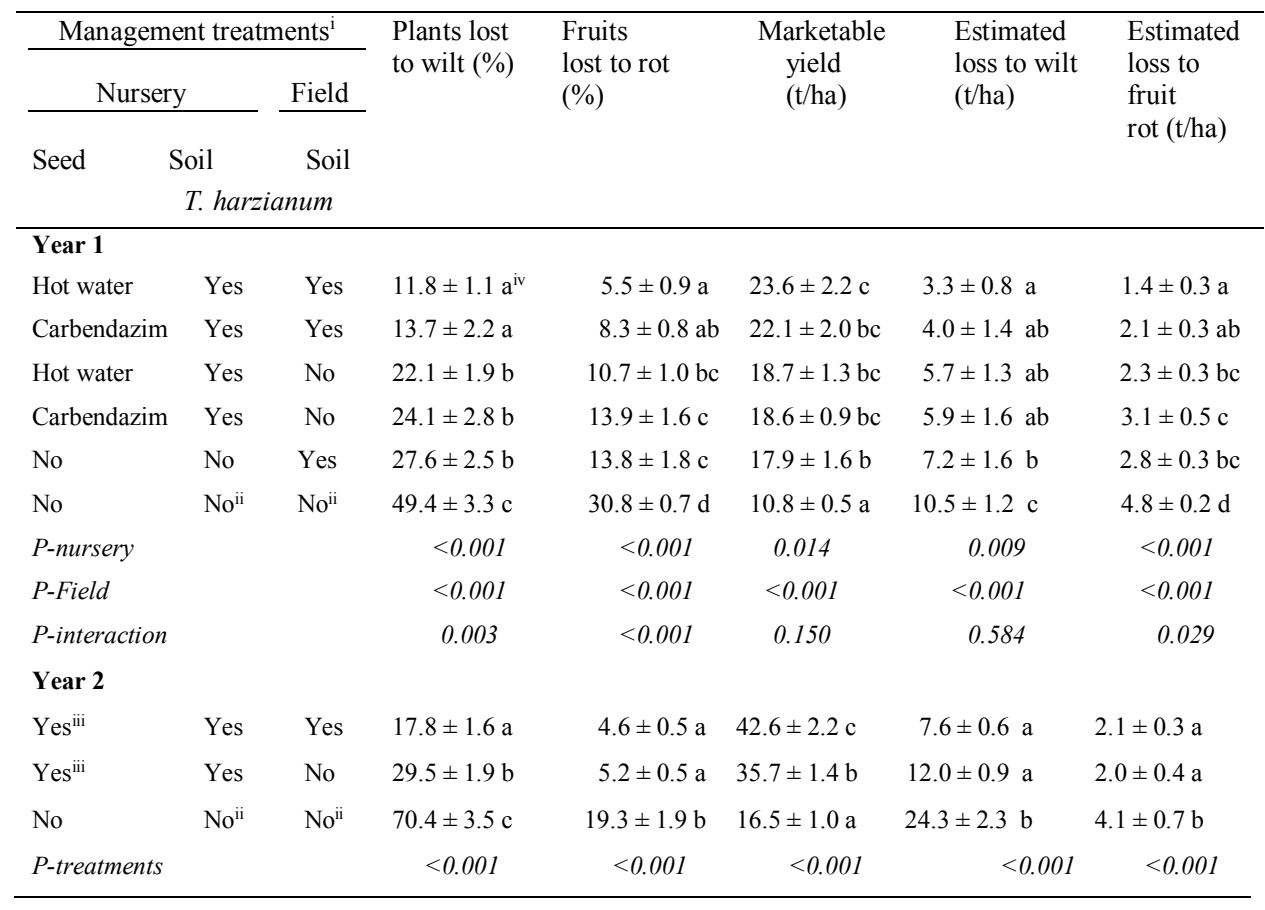

${ }^{i}$ Management included a combination of seed and soil treatments in the nursery and soil treatment in the field as indicated. ${ }^{\text {ii }}$ Farmers' practice had no preventive treatment just spraying after appearance of diseases. ${ }^{\text {iii }}$ In Year 2 the hot water and Carbendazim seed treatments had similar effects and were therefore combined. ${ }^{\text {iv }}$ Values per year within a column followed by the same letter did not differ significantly according to the Bonferroni post-hoc test.

\subsection{Marketable yield of eggplant and profitability of different managements}

The highest marketable eggplant yield of 23-42 $\mathrm{tha}^{-1}$ in Year 1 and 2 respectively, was obtained from the combined nursery and field treatment followed by 18-35 $\mathrm{t} \mathrm{ha}^{-1}$ from only nursery management. These yields were 8-13 $\mathrm{tha}^{-1}$ (Year 1) and 19-26 $\mathrm{t} \mathrm{ha}^{-1}$ (Year 2) higher than under farmer conventional practice (Table 1). The assessment of costs and income showed that when eggplant prices are average farmers could earn more than $€ 2000-5700 \mathrm{ha}^{-1}$ by combining improved nursery and field practices, and around $€ 2000-4800$ ha $^{-1}$ by improving the nursery management only (Table 2). Following their conventional practices farmers could earn only $€ 200-1100$ per ha. The analysis also showed that farmers could make a profit with improved management even in low price years, while farmers would face losses with their conventional 


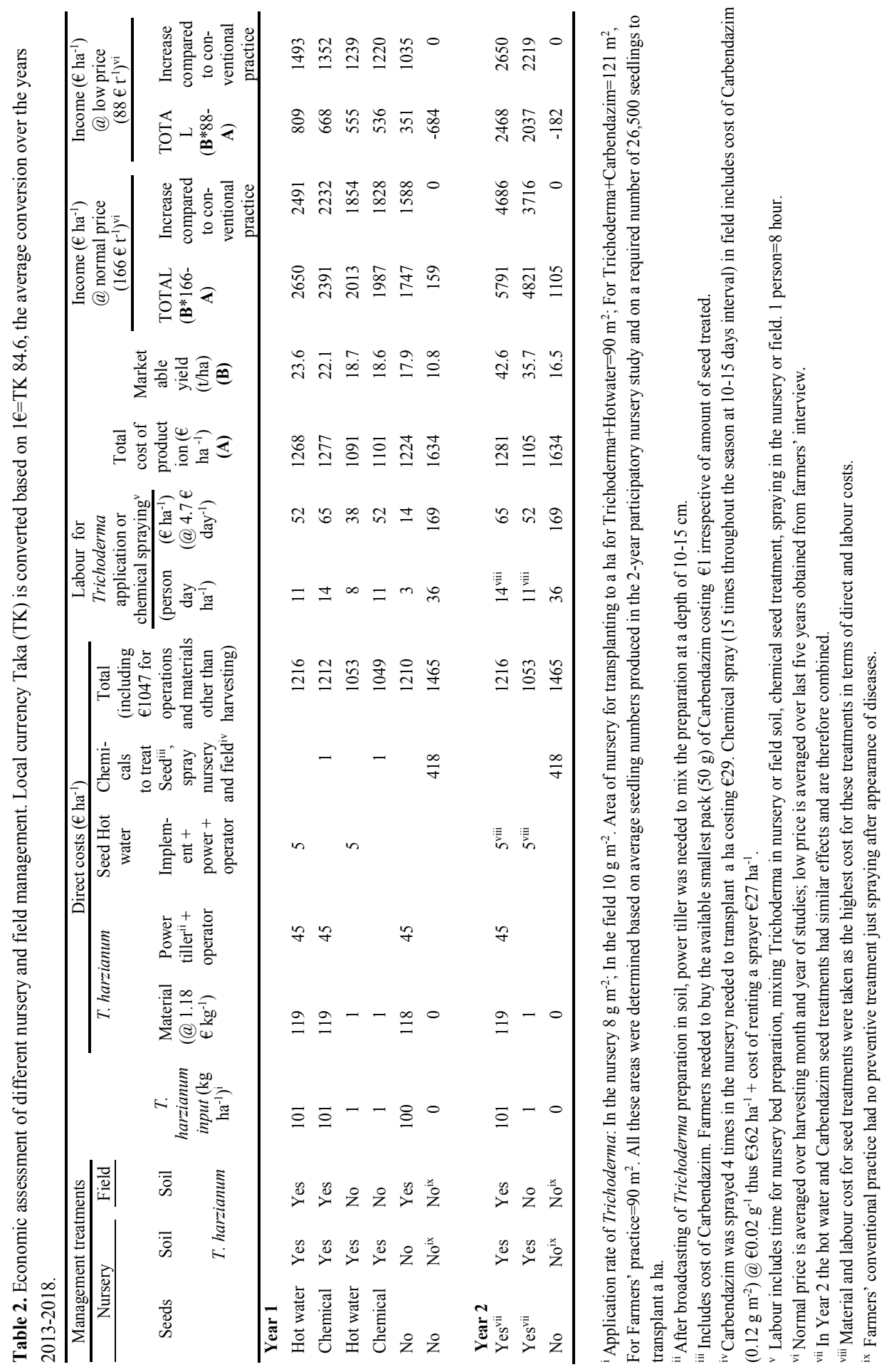




\section{Chapter 3}

practice in a low price year. Farmers practice costed at least twice the money needed for the improved management packages when only material input cost was considered. Therefore, with any of the improved practices, farmers could make at least 10 times more money than with their conventional practices both in a normal and a low price year (Table 2).

\subsection{Loss of plants to bacterial wilt in farmers' fields and the experiments}

The survey data of 15 fields in the village territory indicated comparable trends in all three years with $7-11 \%$ of plants lost to wilt shortly after transplanting, reaching $23-30 \%$ plant loss at flowering and around $50 \%$ during fruiting while reaching up to $60 \%$ at the end of the eggplant growing season (Table 3). This loss compares well with the observations on the farmer conventional management in our experiments in two of the three seasons (Fig. 1). Bacterial wilt symptoms in the experiments appeared within a week or so after transplanting and continued up to final harvest (Fig. 1). However, improved nursery plus field management or only improved nursery management, delayed onset of wilt by at least a week and reduced final losses compared to farmers' practice. Wilt started 10-19 DAT with plant loss reaching $0.4-4.3 \%$ in farmers' practice plots against $0-0.5 \%$ in treated plots. The progression over time of losses to wilt follow a smooth increase to reach the effects reported in Table 1. Higher final losses thus are accompanied by an earlier loss of more plants too (Fig. 1). The occurrence and magnitude of fruit rot was only monitored in the experimental fields. Fruit rot was observed at all eggplant harvests and losses remained more or less constant over time for the improved nursery management only, improved nursery and field management and farmers practice with around 13, 7 and 31\% respectively in Year land and 3, 2.5 and $14.5 \%$ in Year 2.

Table 3. Percentage of plants lost to bacterial wilt in farmers' fields (Pirijpur village, Jamalpur, Bangladesh) at different stages indicated in days after transplanting (DAT) during three cropping seasons

\begin{tabular}{lccccc}
\hline Survey year & $\begin{array}{l}\text { Number of } \\
\text { fields } \\
\text { surveyed }\end{array}$ & $\begin{array}{l}\text { Establishment } \\
\text { (20 DAT) }\end{array}$ & $\begin{array}{l}\text { Flowering } \\
\text { (60 DAT) }\end{array}$ & $\begin{array}{l}\text { Peak fruiting } \\
\text { (100 DAT) }\end{array}$ & $\begin{array}{l}\text { End of season } \\
\text { (150 DAT) }\end{array}$ \\
\hline $2015-2016$ & 15 & 7.6 & 25.0 & 41.3 & 45.5 \\
$2016-2017$ & 15 & 9.3 & 22.9 & 43.0 & 51.5 \\
$2017-2018$ & 15 & 11.3 & 30.1 & 48.1 & 57.1 \\
\hline
\end{tabular}



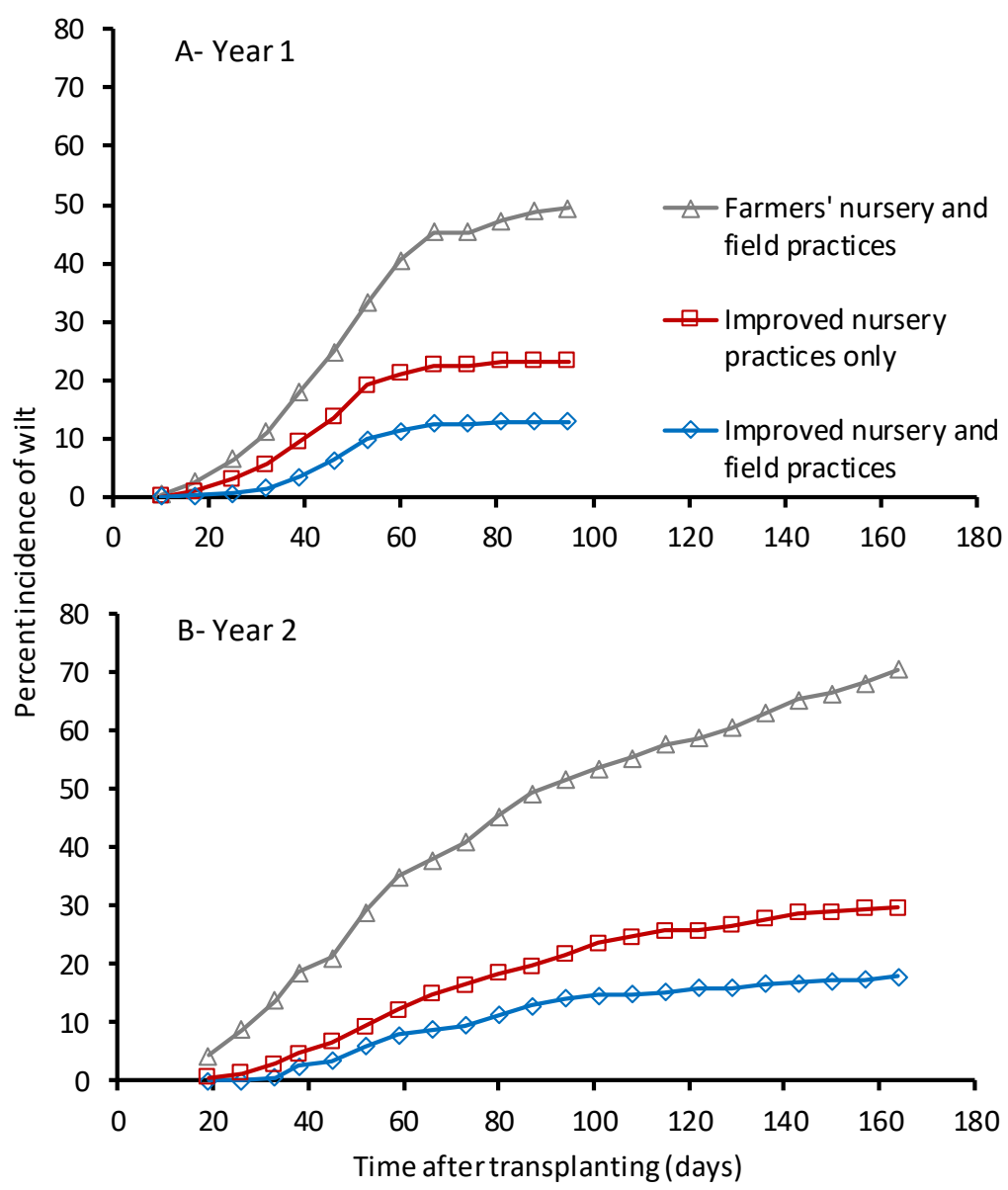

Fig. 1. Percent cumulative bacterial wilt over the season in the Year-1 (top) and Year-2 (bottom) studies, comparing farmers' practice in nursery and field with improved nursery management only (averaged over the two seed treatments) and improved nursery and field management (averaged over the two seed treatments). The crop started flowering around 60 days after transplanting (DAT), produced fruits between 80 and 160 DAT with a peak in fruiting from 90 to 140 DAT. Improved nursery management included soil application of $T$. harzianum and seed treating with either hot water or Carbendazim; improved field management included soil application of T. harzianum. Farmers' practice included no seed or soil treatment but spraying at appearance of damping-off (nursery) or wilt (field). 


\section{Chapter 3}

\subsection{Plant growth and farmer evaluation of different management options}

In Year 2, plant growth was measured and assessed with farmers at the end of the season (170 DAT). For all observed variables, except shoot length, plants obtained with improved nursery management alone or with both improved nursery and field management were significantly superior to plants from farmers' practice plots (Table 4), while no differences were observed between treating both nursery and field or treating nursery only. Shoot length was superior only when both field and nursery management were improved. Improved management increased rooting depth and shoot length by $6-7 \mathrm{~cm}$ and stem diameter by $1-1.5 \mathrm{~cm}$ compared to plants from farmers' conventional practice plots. In addition, the number of lateral roots almost doubled and the number of branches increased by 5-6.

Farmers' appreciation of the plants and the overall condition of the crop at the end of the season were in line with these measurements indicating farmers also appreciated plants from improved practices, as better and healthier than plants from their own practice plots (Table 4). Farmers considered their crops as "poor" and the crop from improvement management plots as "good"; this appreciation was mostly based on improvements in stem diameter, rooting depth, and number of branches.

\subsection{Persistence of T. harzianum in the study fields and its influence on target and non-target} pathogens

The soil testing revealed that the applied T. harzianum persisted in all treated plots of farmers at the end of the season, 175 days after after transplanting (Table 5). The population density was higher $\left(2.0 \times 10^{4} \mathrm{CFU} \mathrm{g^{-1 }}\right.$ of soil $)$ in plots where $T$. harzianum had been applied at transplanting and seedlings raised in $T$. harzianum amended soil were transplanted. $T$. harzianum was also detected $\left(0.9 \times 10^{4} \mathrm{CFU} \mathrm{g}^{-1}\right.$ of soil) in the fields where seedlings from $T$. harzianum treated nurseries were transplanted but no T. harzianum was directly applied (Table 5). T. harzianum was not detected in soil from farmers' practice plots, however, a low but detectable level of a native Trichoderma spp. $\left(0.2 \times 10^{4} \mathrm{CFU} \mathrm{g}^{-1}\right.$ of soil $)$ was recorded, but not identified at species level. This native species was not observed in improved practice plots.

Populations of the pathogenic fungus, $P$. vexans and wilt bacterium $R$. solanacearum were significantly reduced in improved management plots by half compared to farmers' practice plots (Table 5). For $P$. vexans this reduction was only significant when both field and nursery were treated. For $R$. solanacearum a significant additional reduction was observed when both field and nursery were treated compared to nursery only. The non-pathogenic Aspergillus $s p$. 

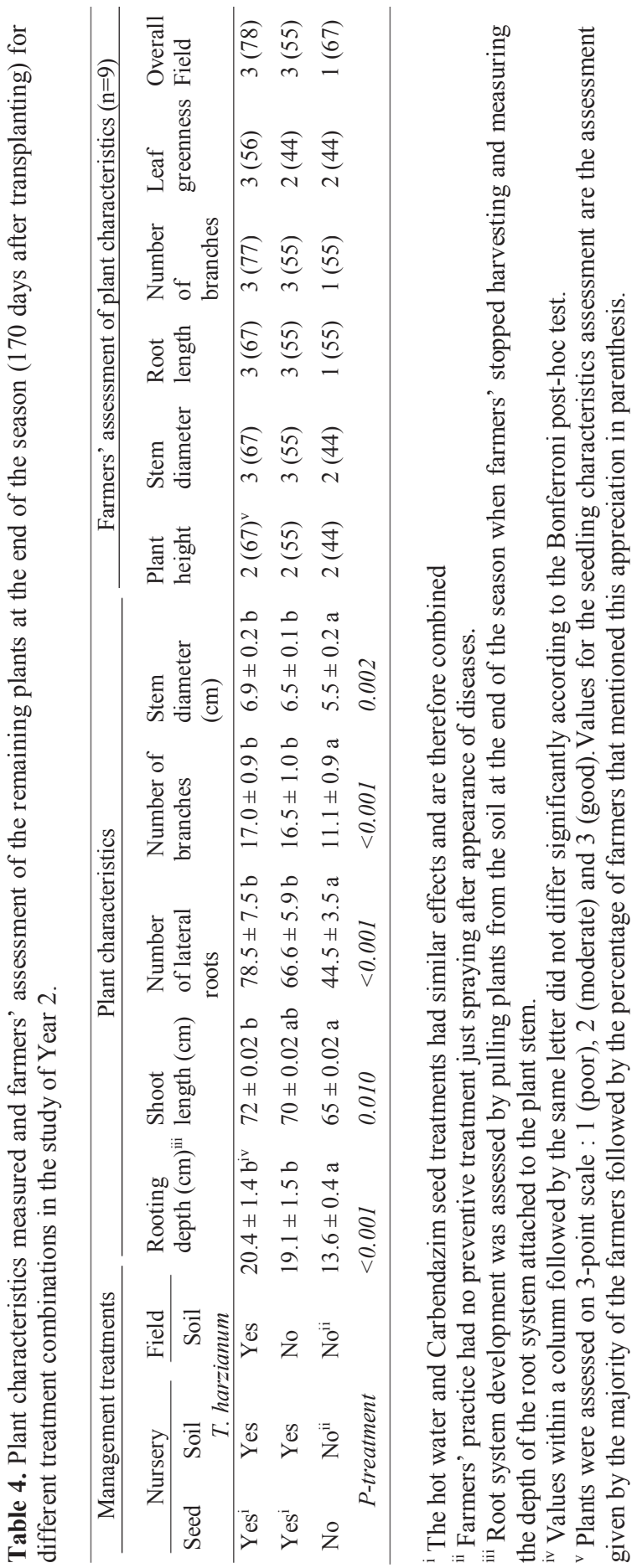


\section{Chapter 3}

was not influenced by improved practices; however, populations of another non-pathogenic fungus Penicillium sp., were significantly reduced compared to farmer practice plots. Population density of these fungi and bacteria were comparable between plots of the two improved practices.

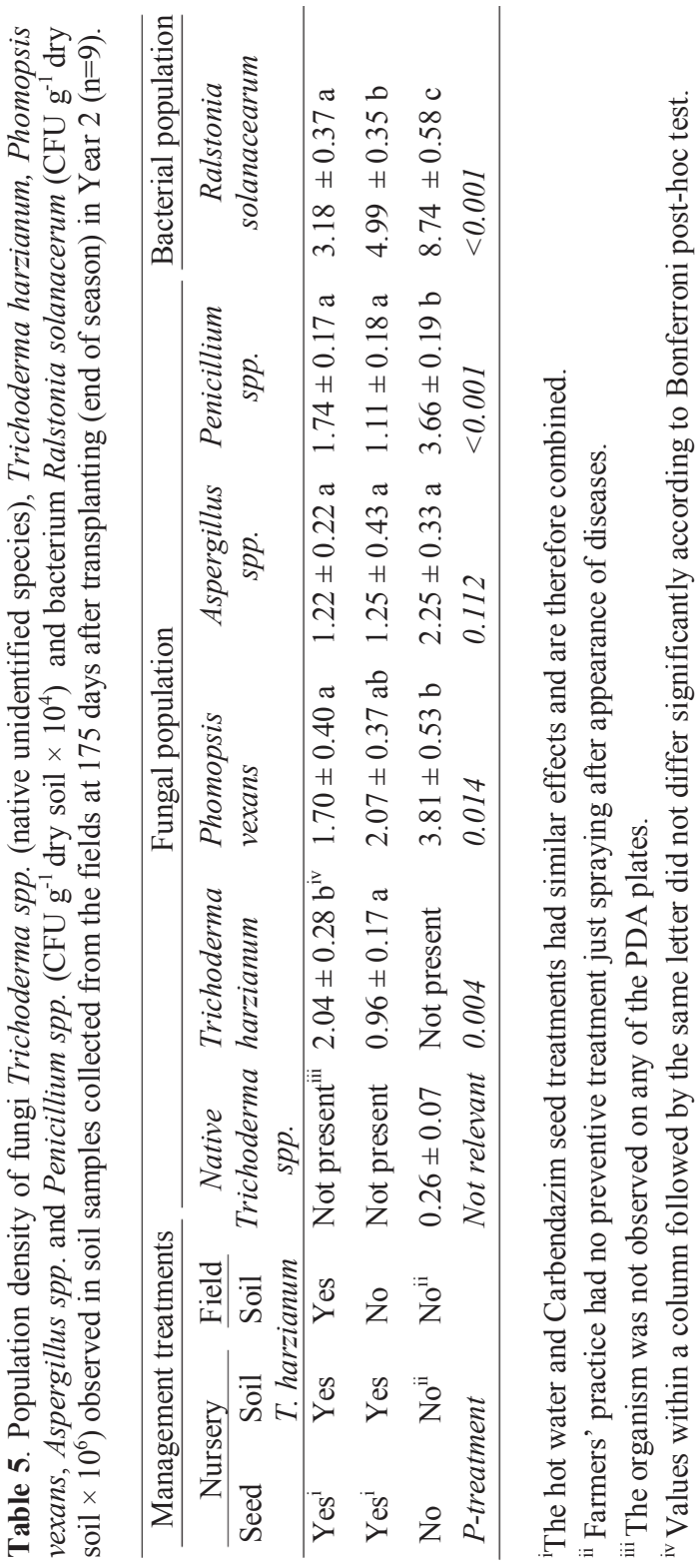


3.6. Incidence of $R$. solanacearum, P. vexans and T. harzianum in seeds preserved from eggplants in experimental fields of Year 2

Seeds from eggplants produced in the Year 2 study were processed separately per treatment and tested in-vitro. $R$. solanacearum was detected on $31.8 \pm 4.1 \%(\mathrm{n}=9)$ of the seeds from farmers' practice plots against $6 \pm 1.1 \%(\mathrm{n}=9)$ of the seeds from improved nursery and field management plots and $10.5 \pm 1.5 \%(\mathrm{n}=9)$ from improved nursery management only plots. $P$. vexans was detected on $3 \pm 0.3 \%(\mathrm{n}=9)$ of the seeds from farmers' practice plots against $0.4 \pm 0.4 \%(\mathrm{n}=9)$ of the seeds from improved nursery management only plots and no $P$. vexans was detected from improved nursery and field management plots.

T. harzianum was detected in seeds, although at a lower percentage from improved nursery and field management plots and improved nursery management only plots respectively and not in seeds from farmers practice plots.

\subsection{Source of infection of $R$. solanacearum and $P$. vexans}

Laboratory test of soil collected from farmers' fields and seeds collected from farmers' preserved seed prior to the Year 1 study showed $R$. solanacearum population as $9.5 \times 10^{6} \mathrm{CFU}$ $\mathrm{g}^{-1}$ of soil $(\mathrm{n}=7)$ and $28.7 \pm 8.9 \%(\mathrm{n}=7)$ of the seeds were infected with $R$. solanacearum. $P$. vexans was detected in soil; however, it was not quantified, and $2.8 \pm 0.5 \%(\mathrm{n}=7)$ of seeds were infected with $P$. vexans, confirming soil and seed as a source of infection.

On seedlings raised from farmers' seed of Year $1(\mathrm{n}=8$, seven farmers who participated in the Year 1 study and one additional farmer from the village) and tested in the laboratory, on average $31.2 \pm 6.1 \%$ of seedlings across farmers was detected with latent infection of $R$. solanacearum which confirmed seed to seedling transmission of the pathogen, and thus, seedling as a source of infection and possible carry-over of the pathogen from nursery to field. Such test was not done for $P$. vexans.

\subsection{Role of T. harzianum in seedling infection}

Seedlings carried $R$. solanacearum as latent infection when screenhouse-grown seedlings were tested three weeks after emergence, roughly the age of farmers' transplanted seedlings. Seedlings grown on soil treated with $T$. harzianum and from seeds treated with hot water and only on soil treated with $T$. harzianum both showed significantly $(P<0.001)$ reduced infection compared to untreated control (15-22\% vs 60\%); however, treatments could not annihilate the infection. This suggests a role of T. harzianum and seed treatment in reducing $R$. solanacearum infection through carry-over with seedlings. 


\section{Chapter 3}

\section{Discussion}

A farmer-targeted integrated management of eggplant production against bacterial wilt, caused by $R$. solanacearum, and fruit rot, caused by $P$. vexans, was tested together with farmers. Seedlings transplanted from nurseries under improved management (farmers' nursery soil treated with T. harzianum and farmers' seed treated either with hot water or Carbendazim) either into untreated farmers' fields or into farmers' fields amended with soil applied $T$. harzianum, were found to reduce both diseases and increase yield and income compared to farmers' conventional practice (Tables 1 and 2). The costs of the introduced technology was lower than the costs of current farmers' practices, in terms of both labour and purchased materials. While improved nursery management alone had already a large effect, adding a field soil application of $T$. harzianum had an additional positive effect on reduction of wilt and on marketable yield. Wilt contributed more to yield losses than fruit rot. Laboratory testing of field soils showed that $T$. harzianum persisted until the end of the growing season and significantly reduced the population of both $R$. solanacearum and $P$. vexans in the soil and on the seeds collected from the eggplants.

\subsection{Improved management effectively reduced bacterial wilt and Phomopsis fruit rot and improved plant health; farmers' practice was ineffective}

Improved management (nursery only, nursery and field combined) substantially reduced bacterial wilt and fruit rot. Nursery only management reduced plant losses to wilt by 25-40 percentage points and fruit losses to rot by 14-20 percentage points compared to farmers' practice of spraying (Table 1). While the superior quality and vigour of the seedlings after the nursery management aimed at controlling damping-off (Nahar et al., 2018) could be expected to contribute to withstanding pathogens (Read and Stokes, 2006; Mastouri et al., 2010), the current research also showed that further defence against diseases is provided by adding $T$. harzianum to the soil after transplanting (Table 1). Further 10 percentage points reduction of wilt and 5 percentage points reduction of fruit rot was achieved when a field soil application of T. harzianum was combined with improved nursery management. Transplanting seedlings from farmers' conventional nursery practice with conventional field disease control failed to manage bacterial wilt and Phomopsis fruit rot. Due to bacterial wilt , farmers loose around $30 \%$ plants before fruit bearing (Fig. 1) increasing to $50-70 \%$ at the end of season (Fig. 1, Table 1). Due to fruit rot (P. vexans), farmers failed to harvest 19-30\% eggplant fruits (Table 1). Higher wilt incidence in the farmers' conventionally managed field can be attributed to higher latent 
infection carry-over with seedling after conventional than improved management as established in laboratory testing (section 3.8). This means seedlings bear latent infection and thus carryover $R$. solanacearum when transplanted and initiate infection soon after transplanting. Because $7-14 \%$ of the seedlings was lost within a month of transplanting (Fig. 1) this initial loss was most likely not a new infection from the field. In contrast, seedlings from improved practices bear substantially lower infection, consequently carry-over less through transplanting to the field and this likely delayed onset of infection and reduced infection throughout the season (Fig. 1). Latent infection of $P$. vexans in seedling was not tested, because, based on seedling characteristics of our nursery study (Nahar et al., 2018) it was likely to be free of $P$. vexans. Therefore, less rot development in field is partly attributed to transplanting of healthy seedlings.

The improved health of transplants from improved nursery management (Nahar et al., 2018) practices showed still at the end of the season (Table 4), especially in terms of increased number of branches, lateral roots and root length. These traits of the transplants also likely play a role in combating diseases. T. harzianum, either field applied or carried over from the nursery (Table 5 , most likely via seedling root association) might have played a role in improved plant growth directly or through disease reduction. Trichoderma spp. has been reported to enhance plant growth by controlling deleterious root microorganisms, producing growth stimulating factors, promoting availability of necessary nutrients, reducing concentration of growth inhibitory substances and increasing nutrient uptake through enhanced root growth (Harman, 2000; Harman, 2006; Lorito et al., 2010; Harman, 2011). Measurement of plant growth was done only in Year 2 as farmers were hesitant to allow us to jointly uproot plants in Year 1. In Year 2, farmers were more convinced by the results and when requested to evaluate plant growth, they appreciated all variables and overall appearance of the improved management field as "good".

\subsection{Improved management improves yield and reduces cost effectively}

Improved nursery management alone increased yield by $8-19 \mathrm{t} \mathrm{ha}^{-1}$ compared to farmers' conventional practice, while the combination of nursery management and field application of T. harzianum increased yield by an extra 4-7 $\mathrm{t} \mathrm{ha}^{-1}$ (Table 1). In Year 1, a comparable yield to nursery management alone was obtained when only the field was treated with T. harzianum. Farmers' were not interested in repeating this treatment in Year 2 as treating the nursery reduced seedling losses and led to better quality seedlings making their work more effective (Nahar et al., 2018). Moreover the costs of the T. harzianum application to the nursery is much smaller than field application. The treatment was thus not tested given the joint definition of treatments to be tested in this participatory set-up. 


\section{Chapter 3}

Nursery practices, field practices and their combination costed $€ 50$ (44-58), €177 and $€ 228$ (221-235) ha ${ }^{-1}$ respectively, all substantially lower than costs of current farmers’ practice (€587) (Table 2). The advice to farmers can be to start by treating the seed and nursery soil both as costs are lowest and it provides farmers with more certainty on producing good and sufficient transplants (Nahar et al., 2018). This is in line with farmers' reasoning as shown by the refusal to test a field only application in Year 2. After treating seed and nursery soil whether the field soil should be treated or not may depend on the capacity of farmers to invest in the additional labour and input. The cash costs of $€ 178 \mathrm{ha}^{-1}$ led to $€ 500$ (Year 1) to $€ 900$ (Year 2) extra income (Table 2). In years with a low price this may be as low as $€ 200$ to $€ 400$ (Table 2). In conclusion, as price of eggplant fluctuates between years, the recommendation to also treat the field soil should be introduced with some care. In a low eggplant price year, farmers' practice provided little or even negative income when all material input expenses were included. When labour was considered at formal price the losses were more substantial. Farmers currently provide all necessary labour themselves, meaning they may not consider labour costs. Yet their labour income in Euro per day would be low and well below the current formal price. With the proposed practices their labour will become more remunerative especially in average price years.

The large yield and income differences between two years were also because farmers offered poor quality land and transplanted late in Year 1, whereas in Year 2 they tested all treatments in their own nurseries and main eggplant field.

\subsection{T. harzianum persisted in field soil and reduced target pathogen $R$. solanacearum and $P$. vexans}

We observed T. harzianum in the field soil samples from improved management plots at the end of the season, 175 days after transplanting while populations of $R$. solanacearum and $P$. vexans in those samples were reduced (Table 5), fully in line with the lower disease incidence in the crop. Presence of T. harzianum in soil that was not amended with T. harzianum but to which seedlings from $T$. harzianum enriched nursery soil had been transplanted suggests the fungus is carried-over from nursery to main field (Hadar et al.,1984) via roots or the adhering rhizosphere soil. This corresponds to reports that it can establish on plant roots (Harman et al., 2004; Shoresh and Harman, 2008; Hermosa et al., 2012; Brotman et al., 2013). T. harzianum showed good adaptability in tested environmental conditions given the concentration of $2.0 \times 10^{4}$ CFU $\mathrm{g}^{-1}$ observed in the field soil) at the end of the season. Indeed, the $\mathrm{pH}$ of 6.5 in the experimental fields fit requirements for growth and survival T. harzianum (Burpee, 1990), 
while also the formulation with peat soil and black gram bran likely supplied an adequate starter food base for its growth and proliferation. Persistence of Trichoderma spp. after single inoculation has been documented earlier in other crops (Longa et al., 2009; Larkin, 2016; Oskiera et al., 2017).

There is debate whether biocontrol agents may negatively affect non-target organisms, especially if non-native organisms are introduced (Brimner and Boland, 2003). The check on other soil mycoflora, particularly Aspergillus sp. and Penicillium sp. (Table 4) showed $T$. harzianum application indeed changed one but not both organisms. In the same line, native Trichoderma spp. were no longer observed when T. harzianum was observed. This differs from a number of other studies that observed no negative effect of Trichoderma on non-target soil microbiome (Harman, 2000; Whipps and Lumsden, 2001; Bankhead et al., 2004; Kiss, 2004). It may thus still warrant further study to understand the extent and consequences of the use of T. harzianum especially in the longer term. Yet, the application is preferred over the use of biocides.

\subsection{Improved management effects of one season can carry-over to a next season}

The lower populations of $R$. solanacearum and $P$. vexans in improved management field may in fact imply that a next crop will start with a lower level of disease pressure. Similarly, lower population of both pathogens in seeds preserved from improved fields indicates reduced plantto-seed transmission of pathogens and thus making seedlings pathogen free. Presence of $T$. harzianum in improved seeds indicates its transmission from plant to seed which will be helpful for disease reduction in next year crops.

\subsection{Towards developing and implementing an IPM package for farmers}

To develop a sustainable disease management package for farmers, we first confirmed the prevalence of bacterial wilt and Phomopsis fruit rot in farmers' fields by identifying the two major pathogens $R$. solanacearum and $P$. vexans by in-vitro testing of diseased plants and fruits collected from farmers' fields. As there was no proper documentation of wilt severity, we also surveyed farmers' fields for three years. Plant loss to bacterial wilt started just a few days after transplanting and continued throughout the season (Table 3 ). The very early plant loss provided a clue that farmers seedlings were most likely not healthy which was further confirmed by invitro testing of the seedlings. Thus improved nursery management should be a prime focus for farmers. 


\section{Chapter 3}

To decide a proper management, determining the infection source of $R$. solanacearum and $P$. vexans was required. Although $R$. solanacearum is considered generally as soil-borne and $P$. vexans as seed-borne (Vishunavat and Kumar, 1994; Pan and Acharya, 1995), in the present study, both pathogens were detected from farmers' seed and soil. Once $P$. vexans is present in eggplant stands, the soil may get contaminated through rotten fruits and crop debris where it can survive for at least up to a year (Panwar et al., 1970; Sharma and Razdan, 2012). Given presence in both soil and seeds we combined a seed treatment either with hot water or Carbendazim and a soil treatment with T. harzianum. For farmers this firstly aimed at avoiding damping-off losses and improving seedling vigour (Nahar et al., 2018). In a further screenhouse test seedlings were found comparatively healthy and substantially less infected after the improved practices than with farmers' control (15-22\% vs $60 \%)$. Therefore it is plausible that there was less carry-over of pathogens from nursery to field compared to farmers' practice. This result corresponds to the reduced wilt infection with improved practice compared to farmers' practice within a month of transplanting (Fig. 1).

Considering the observed disease reduction and economic feasibility farmers could relatively simply improve their business by stopping the use of the ineffective pesticide spraying and treating their seed with hot water and nursery soil with T. harzianum. Repeated application of ineffective pesticides is a waste of money, will lead to the development of pathogen resistance against fungicide and creates health and environmental hazards (Pingali, 1995; Gerhardson, 2002). Trichoderma spp. has earlier been documented to control a wide range of soil pathogens including bacteria and was reported as safe for the environment and farmers health (Harman, 2000; Whipps and Lumsden, 2001). Hot water treatment is wellknown for controlling a wide range of fungal pathogens (reviewed in Mancini and Romanazzi, 2013), and $R$. solanacearum (reviewed in Yuliar et al., 2015), our data also indicate it does reduce $R$. solanacearum infection of eggplant.

At present $T$. harzianum is not readily available at village level. Farmers would have to obtain Trichoderma from a research station of the national research system or request an agricultural extension staff to collect it for them. There is thus a need to create a business model for local agro-dealers or entrepreneurial farmers. The technology cannot be patented so local businesses will be needed. In the meantime, depending on the availability of Trichoderma, farmers need to take management decisions. If Trichoderma is scarce, farmers can best only treat the nursery because only $8 \mathrm{~g} \mathrm{~m}^{-2}$ is needed. If farmers could not treat the nursery due to 
untimely available Trichoderma because of transport problems at the end of the rainy season when nurseries are planted, it is still worthwhile to treat the field.

As farmers keep their seed over years to raise seedlings, one of the crucial findings from this study is that improved management also reduced both $R$. solanacearum and $P$. vexans seed infestation. Farmers using the improved practices are thus likely to also end up with improved seed, seedlings and consequently better disease reduction in their fields in the next year.

\section{Conclusion}

Sustainability of integrated pest management (IPM) greatly depends on involvement of farmers in the research process and generating solutions integrating ecologically sound and readily available components suitable in their farming systems (Röling and Pretty, 1997; Hagmann et al.,1999; Khoury and Makkouk, 2010). The use of hot water to treat seeds and T. harzianum as soil treatment would fit these criteria if the technology, which is low cost, is made available in Bangladesh. We here showed the large and positive effects on eggplant yield and income in addition to the earlier published positive results on the success in the nursery phase (Nahar et al., 2018). These practices provided feasible low cost disease control compared to farmers' practice and can improve sustainability of eggplant production in the country and probably beyond. Both bacterial wilt and fruit rot were greatly reduced. T. harzianum sustained in the field till the end of eggplant growing season and reduced the population of both $R$. solanacerum and $P$. vexans in the soil and on produced seed. To the best of our knowledge, the present study is the first participatory research to develop an integrated package targeting both bacterial wilt and Phomopsis fruit rot during the field phase and damping-off during the nursery phase by combining nursery and field management in farmers' conditions with farmers. To go from this proof of principle to actual adoption at large scale the following research is still needed: i) Techniques and their feasibility for the local production of $T$. harzianum as soil amendment and local hot water seed treatment as a service to farmers or by farmers individually; ii) Monitor the ability of farmers to sustainably adopt and adapt the improved management practices once the research is over; iii) Systematic evaluation of the influence of T. harzianum on the microbial community in nurseries and fields with adopting farmers to assess long-term main and side effects. 


\section{Chapter 3}

\section{Acknowledgements}

Project was funded by NUFFIC under their NICHE programme (grant number NUFFICNICHE-BGD-156), a collaboration between Wageningen University and Research (WUR) and Bangladesh Agricultural University (BAU). We acknowledge farmers of Pirijpur for participating in the study and allocating land to tests. Thanks to the farmer trainers for assistance in the study, thanks to the villagers for all sorts of co-operation. We acknowledge the support of the Plant Bacteriology and Biotechnology Laboratory, Seed Pathology Centre and the IPM laboratory of BAU and Nico Heerink, WUR for discussions on the economics of the management.

\section{Appendix:}

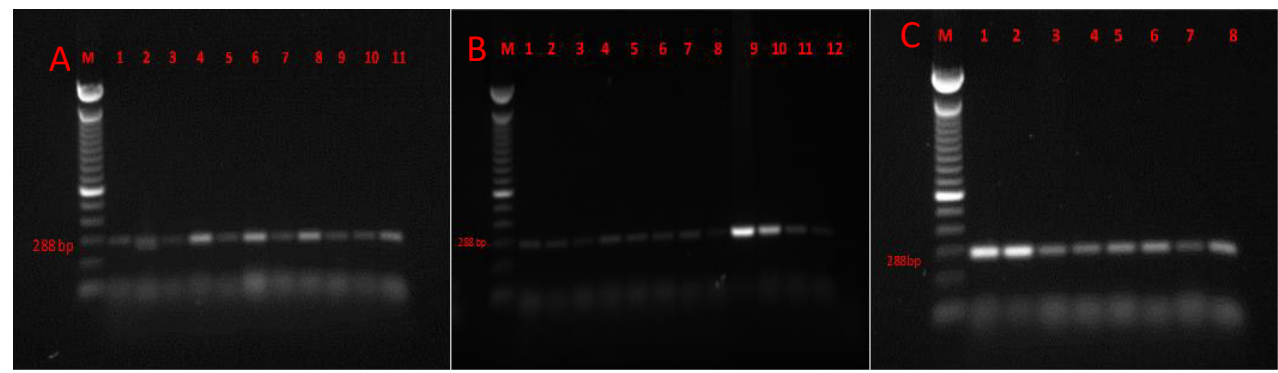

Figure A1: Detection and identification of Ralstonia solanacearum from (A) farmers' seed: Lane 1-7: Seed obtained from seven participating farmers prior to the Year 1 study, Lane 8-11: Seed from four additional farmers. (B) farmers' soil: Lanes 1-7: Soil collected from seven participating farmers' field prior to the Year 1 study, Lanes 8-10: Field soil from three additional farmers; Lanes 11-12: Home garden soil, typically where nurseries are found. (C) Seedlings raised from farmers' seed in farmers' soil: Lanes 1-8: Seedlings from seed obtained from seven participating farmers prior to the Year 1 study and one additional farmer from the same village. Lane $\mathrm{M}$ in all panels: Molecular marker. Molecular marker $1 \mathrm{kbp}$ and primer (OLI-1, Y2) $288 \mathrm{bp}$.

Molecular identification of R. solanacearum from farmers' soil, seed and seedlings

Bacterial isolates of seed (samples 1-7), soil (samples 1-7) and seedlings (samples 1-8) were re-cultured in TTC plates from virulent colonies of tests reported in section 2.4.3. Isolates of seed sample 8-11 and soil sample 8-12 were also obtained by plating them onto TTC media. Bacterial isolates were then inoculated on Kelman's TZC agar slants, labelled and kept in the refrigerator for molecular identification. To extract the DNA, $R$. solanacearum colonies from the preserved agar slants was again streaked onto TTC medium and incubated for 24 hours at $28^{\circ} \mathrm{C}$. Then a loop of bacterial culture from aforesaid media was transferred to $5 \mathrm{ml} \mathrm{CPG}$ broth 
and shaken for 18 hours at $28^{\circ} \mathrm{C}$ by electric shaker. DNA was extracted from this liquid bacterial culture using Wizard ${ }^{\circledR}$ Genomic DNA Purification Kit (Promega, Madison, WI, USA) following manufacturer's protocol for gram negative bacteria. DNA concentration was measured by NanoDrop 2000 spectrophotometer (Thermo Scientific, USA). Before analyses, DNA concentrations were adjusted to $100 \mathrm{ng} / \mu \mathrm{l}$. $R$. solanacearum was detected by using 0.4 $\mu \mathrm{M}$ each of a specific primer OLI-1(5'-GGGGGTAGCTTGCTACCTGCC-3') and nonspecific primer Y2 (5'- CCCACTGCTGCCTCCCTAGGAGT-3') (Ramesh et al., 2011). PCR was performed in a total $25 \mu \mathrm{l}$ of reaction mixture using $12.5 \mu \mathrm{l}$ of GoTaqR G2Green Master Mix $(400 \mu \mathrm{M}$ dNTPs, $1 \mathrm{X}$ PCR reaction buffer $\mathrm{pH} 8.5,3 \mathrm{mM} \mathrm{MgCl} 2,0.5 \mathrm{U}$ Taq DNA polymerase) [Promega, Madison, WI, USA], $1 \mu \mathrm{l}$ of each of the primer, $9.5 \mu 1$ of nuclease free water and $100 \mathrm{ng}(1 \mu \mathrm{l})$ of genomic DNA on a T100 thermal cycler (Bio-Rad, Hercules, CA, USA). Amplification was carried out with an initial denaturation at $96^{\circ} \mathrm{C}$ for $2 \mathrm{~min}$, followed by 35 cycles of $20 \mathrm{~s}$ denaturation at $94{ }^{\circ} \mathrm{C}$, annealing for $20 \mathrm{~s} 68^{\circ} \mathrm{C}$, extension for $30 \mathrm{~s}$ at $72{ }^{\circ} \mathrm{C}$, and a final extension for $10 \mathrm{~min}$ at $72{ }^{\circ} \mathrm{C}$. The amplified products were separated by gel electrophoresis using $1.25 \%$ agarose in $1 \mathrm{X}$ TBE buffer (Tris base, boric acid and $0.5 \mathrm{M}$ EDTA [pH 8.0]) containing ethidium bromide $(0.5 \mu \mathrm{g} / \mathrm{ml})$ and visualize under UV trans illuminator of Alpha Imager HP System (ProteinSimple, San Jose, CA, USA).

\section{References}

Aktar, M.W., Sengupta, D., Chowdhury, A., 2009. Impact of pesticides use in agriculture: alleviates biotic, abiotic, and physiological stresses in germinating seeds and seedlings. Phytopathology $100,1213-1221$.

Bankhead, S.B., Landa, B.B., Lutton, E., Weller, D.M., Gardener, B.B.M., 2004. Minimal changes in rhizobacterial population structure following root colonization by wild type and transgenic biocontrol strains. FEMS Microbiol. Ecol. 49, 307-318.Benitez, T., Rincon, A.M., Limon, M.C., Codon, A.C., 2004. Biocontrol mechanism of Trichoderma strain. Int. Microbiol. 7, 249260 .

Bentley, J.W., 2009. Impact of IPM extension for smallholder farmers in the tropics. In: Peshin, R., Dhawan, A.K. (Eds.), Integrated Pest Management: Dissemination and Impact. Springer, Berlin, Germany, pp. 333-346.

Brimner, T.A., Boland, G.J., 2003. A review of the non-target effects of fungi used to biologically control plant diseases. Agric. Ecosyst. Environ., 100, 3-16.

Brotman, Y., Landau, U., Cuadros-Inostroza, Á., Takayuki, T., Fernie, A.R., Chet, I., Viterbo, A., Willmitzer, L., 2013. Trichoderma-plant root colonization: escaping early plant defense responses and activation of the antioxidant machinery for saline stress tolerance. PLoS Pathogens 9, 1003221. 


\section{Chapter 3}

Burpee, L.L., 1990. The influence of abiotic factors on biological control of soilborne plant pathogenic fungi. Can. J. Plant Pathol. 12, 308-17.

Chowdhury, M.A.Z., Fakhruddin, A.N.M., Islam, M.N., Moniruzzaman, M., Gan, S.H., Alam, M.K., 2013. Detection of the residues of nineteen pesticides in fresh vegetable samples using gas chromatography-mass spectrometry. Food Control 34, 457-465.

Dasgupta, S., Meisner, C., Huq, M., 2005. Health Effects and Pesticide Perception as Determinants of Pesticide Use: Evidence from Bangladesh. World Bank Policy Research Working Paper 3776. World Bank, Washington, DC.

Dasgupta, S., Meisner, C., Huq, M., 2007. A pinch or a pint? Evidence of pesticide overuse in Bangladesh. J. Agric. Econ. 58, 91-114.

Dubey, S.C., Bhavani, R., Singh, B., 2011. Integration of soil application and seed treatment formulations of Trichoderma species for management of wet root rot of mungbean caused by Rhizoctonia solani. Pest Manage. Sci. 67, 1163-1168.

Dugan, F.M., 2008. The Identification of Fungi: an Illustrated Introduction with Keys, Glossary and Guide to Literature, second ed. APS. Press, St. Paul. Minnesota, USA.

Ecobichon, D.J., 2001. Pesticide use in developing countries. Toxicology 160, 27-33.

Gautam, S., Schreinemachers, P., Uddin, M.N., Srinivasan, R., 2017. Impact of training vegetable farmers in Bangladesh in integrated pest management (IPM). Crop Prot. 102, 161-169.

Gerhardson, B., 2002. Biological substitute for pesticides. Trends Biotechnol. 20, 338-343.

Ghosh, S.K., 2017. Study of some antagonistic soil fungi for protection of fruit rot (Phomopsis vexans) and growth promotion of brinjal. Int. J. Adv. Res. 5, 485-494.

Hadar, Y., Harman, G.E., Taylor, A.G., 1984. Evaluation of Trichoderma koningii and T. harzianum from New York soils for biological control of seed rot caused by Pythium spp. Phytopathology 74, 106-110.

Hagmann J., Chuma E., Murwira K., Connolly M., 1999. Putting process into practice: Operationalizing participatory extension. Network Paper, Agricultural Research and Extension Network, ODI (UK), No. 94.

Harman, G.E., 2000. Myths and dogmas of biocontrol changes in perceptions derived on Trichoderma harzianum T-22. Plant Dis. 84, 377-393.

Harman, G.E., 2006. Overview of mechanisms and uses of Trichoderma spp. Phytopathology 96, 190194.

Harman, G.E., 2011. Multifunctional fungal plant symbionts: new tools to enhance plant growth and productivity. New Phytol. 189, 647-649.

Harman, G.E., Howell, C.R., Viterbo, A., Chet, I., Lorito, M., 2004. Trichoderma species-opportunistic, avirulent plant symbionts. Nat. Rev. Microbiol. 2, 43-56. 
Hermosa, R., Viterbo, A., Chet, I., Monte, E., 2012. Plant-beneficial effects of Trichoderma and of its gene. Microbiology 158, 17-25.

Howell, C.R., 2006. Understanding the mechanism employed by Trichoderma virens to effect biological control of cotton diseases. Phytopathology 96, 178-180.

Islam, M.R., Mondal, C., Hossain, I.,Meah, M. B. 2014. Compost tea as soil drench: an alternative approach to control bacterial wilt in brinjal. Arch. Phytopathol. Plant Prot. 47, 1475-1488.

Islam, M.R., Meah, M.B., 2011. Association of Phomopsis vexans with eggplant (Solanum melongena) seeds, seedlings and its management. The Agric. 9, 8-17.

Islam, R., 2005. An Integrated Approach for Management of Phomopsis blight and fruit rot of Eggplant. Ph.D thesis. Bangladesh Agricultural University, Mymensingh.

Jayaramaiah, K.M., Mahadevakumar, S., Raj, A.C., Janardhana, G.R., 2013. PCR based detection of Phomopsis vexans (Sacc. \& Syd.)-The causative agent of leaf blight and fruit rot disease of Brinjal (Solanum melongena L.). Int. J. Life Sci. 7, 17-20.

Khoury, W.E., Makkouk, K., 2010. Integrated plant disease management in developing countries. J. Plant Pathol. 92, 35-42.

Kiss, L., 2004. How dangerous is the use of fungal biocontrol agents to nontarget organisms? New Phytol. 163, 453-455.

Konappa, N., Krishnamurthy, S., Siddaiah, C.N., Ramachandrappa, N.S., Chowdappa, S., 2018. Evaluation of biological efficacy of Trichoderma asperellum against tomato bacterial wilt caused by Ralstonia solanacearum. Egypt. J. Biol. Pest Control, 28, 63. https://doi.org/10.1186/s41938-018-0069-5.

Kulkarni, S., 2015. Commercialisation of microbial biopesticides for the management of pests and diseases. In: Awasthii, L.P. (Eds.), Recent Advances in the Diagnosis and Management of Plant Diseases. Springer, India, $\mathrm{p} 8$.

Larkin, R.P., 2016. Impacts of biocontrol products on Rhizoctonia disease of potato and soil microbial communities, and their persistence in soil. Crop Prot. 90, 96-105.

Lin, L-J., Luther G.C., Hanson P., 2015. Raising healthy tomato seedlings. AVRDC - The World Vegetable Center publication \#15-795. 15 pp.

Longa, C.M.O., Savazzini, F., Tosi, S., Elad, Y. and Pertot, I., 2009. Evaluating the survival and environmental fate of the biocontrol agent Trichoderma atroviride $\mathrm{SC} 1$ in vineyards in northern Italy. J. Appl. Microbiol. 106, 1549-1557.

Lorito, M., Woo, S.L., Harman, G.E., Monte, E., 2010. Translational research on Trichoderma: from proteomics to the field. Annu. Rev. Phytopathol. 48, 395-417.

Ma, X.-H., Chen, Y.,Wang, J.-X., Yu,W.-Y., Tang, Z.-H., Chen, C.-J., Zhou, M.-G., 2009. Activity of carbendazim, dimethachlon, iprodione, procymidone and boscalid against Sclerotinia stem rot in Jinagsu Province of China. Phytoparasitica 37, 421-429. 


\section{Chapter 3}

Mahadevakumar, S., Janardhana, G.R., 2016. Leaf blight and fruit rot disease of brinjal caused by Diaporthe vexans (Phomopsis vexans) in six agro-ecological regions of south West India. Plant Pathol. Quarantine. 6, 5-12.

Mancini, V., Romanazzi, G., 2013. Seed treatments to control seed-borne fungal pathogens of vegetable crops. Pest manage. Sci. 70, 860-868.

Mastouri, F., Björkman, T., Harman, G.E., 2010. Seed treatment with Trichoderma harzianum alleviates biotic, abiotic, and physiological stresses in germinating seeds and seedlings. Phytopathology $100,1213-1221$.

Miah, S.J., Hoque, A., Paul, A. and Rahman, A., 2014. Unsafe use of pesticide and its impact on health of farmers: A case study in Burichong Upazila, Bangladesh. J. Env. Sci. Toxicol. Food Technol. $8,57-67$.

Morse, S., 2009. IPM, ideals and realities in developing countries. In: Radcliffe, E.B., Hutchinson, W.D., Cancelado, R.E. (Eds.), Integrated Pest Management, Concepts, Tactics, Strategies and Case Studies. Cambridge University Press, Cambridge, UK, pp.458-470.

Morse, S., Buhler, W., 1997. IPM in developing countries: the danger of an ideal. Integrated Pest Manage. Rev. 2, 175-185.

Nahar, N., Islam, M.R., Uddin, M.M., de Jong, P., Struik, P.C., Stomph, T.J., 2018. Reducing dampingoff problems in eggplant (Solanum melongena L.): A participatory testing of nursery management in Bangladesh. Crop Prot. 112, 177-186.

Nishat, S., Hamim, I., Khalil, M.I., Ali, M.A., Hossain, M.A., Meah, M.B., Islam, M.R., 2015. Genetic diversity of the bacterial wilt pathogen Ralstonia solanacearum using a RAPD marker. C. R. Biol. 338, 757-767.

Oskiera, M., Szczech, M., Stępowska, A., Smolińska, U. and Bartoszewski, G., 2017. Monitoring of Trichoderma species in agricultural soil in response to application of biopreparations. Biol. Control 113, 65-72.

Pagoch, K., Srivastava, J.N., Singh, A.K., 2015. Damping-off diseases of seedlings in Solanaceous vegetables: current status and disease management. In: Awasthi, L.P. (Ed.), Recent Advances in the Diagnosis and Management of Plant Diseases. Springer, India, pp. 35-46.

Pan, S., Acharya, S., 1995. Studies on the seed borne nature of Phomopsis vexans (Sacc. and Syd.) Harter. Indian Agric. 39:193-198.

Panwar, N.S., Chand, J.N., Singh, H., Paracer, S., 1970. Phomopsis fruit rot of brinjal (Solanum melongena L.) in Punjab. Variability of fungus and role of seed in disease development. Ludhiana J. Agric. 7:641-643.

Parsa, S., Morse, S., Bonifacio, A., Chancellor, T.C., Condori, B., Crespo-Pérez, V., Hobbs, S.L., Kroschel, J., Ba, M.N., Rebaudo, F., Sherwood, S.G., 2014. Obstacles to integrated pest management adoption in developing countries. Proc. Natl. Acad. Sci. 111, 3889-3894.

Pingali, P.L., 1995. Impact of pesticides on farmer health and the rice environment: an overview of results from a multidisciplinary study in the Philippines. In: Pingali, P.L., Roger, P.A. (Eds.), 
Impact of Pesticides on Farmers Health and the Rice Environment. Springer, Dordrecht, Netherlands, pp. 3-21.

Rahman, M. F., Islam, M. R., Rahman, T., Meah, M. B., 2010. Biochemical characterization of Ralstonia solanacerum causing bacterial wilt of brinjal in Bangladesh. Progressive Agric. 21, 9-19.

Rahman, M.H., Alam, M.J.B., 1997. Risk assessment of pesticide use in Bangladesh. J. Civ. Engg. 25, 97-102.

Rahman, Z., 2016. Lack of regulations affect vegetable export. The Financial Express. Published 26 Mar 2016. http://www.thefinancialexpress-bd.com/2016/ 03/26/23070/asia/print. Accessed 07.08.2017.

Ramesh, R., 2008. Bacterial wilt in brinjal and its management. Technical Bulletin No: 10, ICAR, India. pp. 1-3. Research Complex for Goa (Indian Council of Agricultural Research), Ela, Old Goa403 402, Goa, India.

Ramesh, R., Anthony, J., Jaxon, T.C.D., Gaitonde, S. and Achari, G., 2011. PCR-based sensitive detection of Ralstonia solanacearum from soil, eggplant, seeds and weeds. Archives of Phytopathol. Plant Prot. 44, 1908-1919.

Rashid, M.A., Alam, S.N., Rouf, F.M.A., Talekar, N.S., 2003. Socio-economic Parameters of Eggplant Protection in Jessore District of Bangladesh. World Vegetable Center, Shanhua, Taiwan.

Ratha Krishnan, P., Rajwant K. K., Tewari, J.C., Roy, M.M., 2014. Plant nursery management: principles and ractices. Central Arid Zone Research Institute, Jodhpur, 40 pp.

Read, J., Stokes, A., 2006. Plant biomechanics in an ecological context. Am. J. Bot. 93, 1546-1565.

Rifai, M.A.,1969. A revision of the genus Trichoderma. Mycological Papers. 116:1-56.

Röling, N., Pretty, J.N., 1997. Extension's role in sustainable agricultural development. Improv. Agric. Ext. 181-192

Schreinemachers, P., Chen, H.-p., Loc, N.T.T., Buntong, B., Bouapao, L., Guatam, S.,Nhu, T.L., Pinn, T., Vilaysone, P., Srinivasan, R., 2017. Too much to handle? pesticide dependence of smallholder vegetable farmers in Southeast Asia. Sci.Total Environ. 593, 470-477.

Sharma, N., Razdan, V.K., 2012. Perpetuation of Phomopsis vexans on infected seeds, leaf and fruit parts of Solanum melongena L (Brinjal). VEGETOS: Int. J. Plant Res. 25, 196-202.

Sharma, N., Sharma, D.K., 2014. Incidence and seed transmission of $R$. solanacearum (Smith) in brinjal (Solanum melongena L.) seeds. Int. J. Plant Pathol. 5, 63-69.

Shoresh, M. and Harman, G.E., 2008. The relationship between increased growth and resistance induced in plants by root colonizing microbes. Plant Signaling Behav. 3, 737-739.

Shoresh, M., Mastouri, F., Harman, G.E., 2010. Induced systemic resistance and plant responses to fungal biocontrol agents. Annu. Rev. Phytopathol. 48, 21-43. 


\section{Chapter 3}

Singh, B.K., Singh, S., Singh, B.K., Yadav, S.M., 2014. Some important plant pathogenic diseases of brinjal (Solanum melongena L.) and their management. Plant Pathol. J. 13, 208-213.

Srinivas, C., Niranjana, S.R. and Shetty, H.S., 2005. Effect of bioagents and fungicides against Phomoposis vexans and on seed quality of brinjal. Crop Improv. 32, 95-101.

Tahat, M.M., Sijam, K., 2010. Ralstonia solanacearum: The bacterial wilt causal agent. Asian J. Plant Sci. 9, 385-393.

Vanitha, S.C., Niranjana, S.R., Mortensen, C.N., Umesha, S., 2009. Bacterial wilt of tomato in Karnataka and its management by Pseudomonas fluorescens. Biocontrol 54, 685-695.

Vishunavat, K., Kumar, S., 1994. Location of infection of Phomopsis vexans in brinjal seeds. Indian J. Mycol. Plant Pathol., 24:226.

Watanabe, T., 1994. Pictorial Atlas of Soil and Seed Fungi. Lewis Publishers, Boca Raton, Florida.

Whipps, J.M., Lumsden, R.D., 2001. Commercial use of fungi as plant disease biological control agents: status and prospects. In: Butt, T.M., Jackson, C., Magan, N., (Eds.) Fungi as Biocontrol agents: Progress, Problems and Potential. Wallingford, UK: CABI Publishing, pp. 9-22.

Yedidia, I., Srivastva, A.K., Kapulnik, Y., Chet, I., 2001. Effect of Trichoderma harzianum on microelement concentrations and increased growth of cucumber plants. Plant Soil 235, 235242.

Yendyo, S., Ramesh, G.C. and Pandey, B.R., 2017. Evaluation of Trichoderma spp., Pseudomonas fluorescens and Bacillus subtilis for biological control of Ralstonia wilt of tomato. F1000Research 6:2028.

Yuliar, Nion, Y.A., Toyota, K. 2015. Recent trends in control methods for bacterial wilt diseases caused by Ralstonia solanacearum. Microbes Environ. 30:1-11. 


\section{Technical efficacy and practicability of mass trapping for insect control in}

\section{Bangladesh}

Naznin Nahar ${ }^{* 1,2}$, Mohammad Mahir Uddin ${ }^{1}$, Peter de Jong ${ }^{2}$, Paul C. Struik ${ }^{2}$, Tjeerd Jan Stomph $^{2}$

${ }^{1}$ Faculty of Agriculture, Bangladesh Agricultural University (BAU), Mymensingh-2202,

Bangladesh

${ }^{2}$ Department of Plant Sciences, Wageningen University and Research Centre (WUR), 6708

PB Wageningen, The Netherlands

Published as: Nahar, N., Uddin, M. M., de Jong, P., Struik, P. C. and Stomph, T. J., 2020. Technical efficacy and practicability of mass trapping for insect control in Bangladesh. Agronomy for Sustainable Development, 40: 19. https://doi.org/10.1007/s13593-020-00623-6 


\title{
Chapter 4
}

\begin{abstract}
Eggplant shoot and fruit borer (ESFB), Leucinodes orbonalis, is a major pest in eggplant production in South and South-East Asia. Farmers frequently spray insecticides to control it. Integrated pest management (IPM) based on mass trapping or pheromone trapping and sanitation (removal of infested shoots and fruits) has been suggested but poorly adopted. This study tested, together with farmers, combinations of IPM components that fit their farming practices, increase income, and preserve natural enemy populations. A 2-year participatory study was negotiated with these farmers, comparing (i) an untreated control, (ii) farmers' conventional weekly spraying, with pheromone trapping either (iii) alone, or combined with (iv) trap-based biorational spraying, or (v) bi-weekly conventional insecticide spraying. Farmers rejected testing sanitation as too labor-intensive. In both years, pheromone trapping alone or combined with biorational spraying reduced fruit infestation, increased yield and income, and preserved natural enemies, showing technical efficacy at costs comparable with farmers' practice. Replacing biorational spraying by conventional insecticides did not provide any control beyond pheromone trapping alone but reduced natural enemies. In contrast, farmers' practice neither reduced infestation nor increased yield but reduced populations of natural enemies. Aphid and jassid populations were reduced only by biorational and conventional spraying. As farmers were reluctant to use only pheromone trapping, the addition of biorational spraying might be suitable. Discussion with farmers allowed us to understand how practical applicability of the tested IPM depends on farmers' knowledge levels on insect biology, farmers' desire to still use some spraying, and labor constraints to sanitation. Although technically and economically viable, the tested IPM may prove difficult to scale out, as farmers had difficulty understanding the ESFB lifecycle and the pheromone trapping mechanisms. This study is the first to disentangle the technical efficacy of pheromone-trapping-based IPM from its practical applicability for the targeted smallholder eggplant growers.
\end{abstract}

Keywords: Eggplant shoot and fruit borer, Integrated pest management, Pheromone trap, Biorational, Participatory study 


\section{Introduction}

Eggplant (Solanum melongena L.) is economically one of the most important vegetable crops in many Asian countries, including Bangladesh. Farmers, especially small landholders, cultivate eggplant because of its prolonged fruiting period, generating cash income at least once per week for 4-6 months. However, income and production of this vegetable are severely constrained by the caterpillars of a moth, the eggplant shoot and fruit borer (ESFB), Leucinodes orbonalis Guenée (Lepidoptera: Pyralidae) (Alam et al. 2006; Srinivasan 2008). Yield losses of 30 to $90 \%$ have been reported (Srinivasan 2008). During the early vegetative stage, caterpillars penetrate shoot apices, causing these to drop off, thus impeding plant growth. During the fruiting stage, caterpillars mostly infest fruits. Caterpillars tunnel inside the fruit and fill it with excreta, the latter enhancing secondary infection, making the fruit usually unfit for sale and consumption (Srinivasan 2008).

The vast majority of farmers in Bangladesh rely exclusively on chemical insecticides to combat ESFB (Fig. 1a). Farmers spray a variety of broad-spectrum insecticides once per week to daily in the 6-month growing season (Mohiuddin et al. 2009) investing 30-50\% of input costs in insect control (Alam et al. 2006). Frequent use of insecticides threatens farmers' and consumers' health and pollutes the environment (Pimentel 1995; Miah et al. 2014). Indeed, insecticide residues above the maximum residue limits have been detected in eggplants (Chowdhury et al. 2013). Overuse of insecticides also leads to the development of insecticide resistance and kills non-target insects, including natural enemies (Ruberson et al. 1998), resulting in reduced natural pest control. Therefore, eggplant growers need environmentally benign and cost-effective alternatives to broad-spectrum insecticides.

One alternative is to use sex pheromone-based mass trapping. Pheromones are species specific, active in small amounts, nontoxic to vertebrates, beneficial insects, and the environment, and leave no residues on the produce (El-Sayed et al. 2006; Witzgall et al. 2010). Moreover, the small chance of developing pheromone resistance makes it a long-term option for pest control (Witzgall et al. 2010). Pheromone-based practice has been reported to provide efficient management of various Lepidopteran pest species (El-Sayed et al. 2006; Witzgall et al. 2010). Insecticidal control of Lepidopteran borers is difficult, as caterpillars live inside plants, whereas pheromones target the adults, which live outside plants. Moreover, pheromone trapping could support the timing of targeted additional spraying, limiting insecticide use (Cruz et al. 2012). ESFB female sex pheromones have already been identified and synthetically produced (Zhu et al. 1987), and the efficacy of blends of two major components, (E)-11- 


\section{Chapter 4}

hexadecenyl acetate (E11-16:Ac) and (E)-11-hexadecen-1-ol (E11-16:OH), has been tested to suppress the male moth population (Cork et al. 2001).

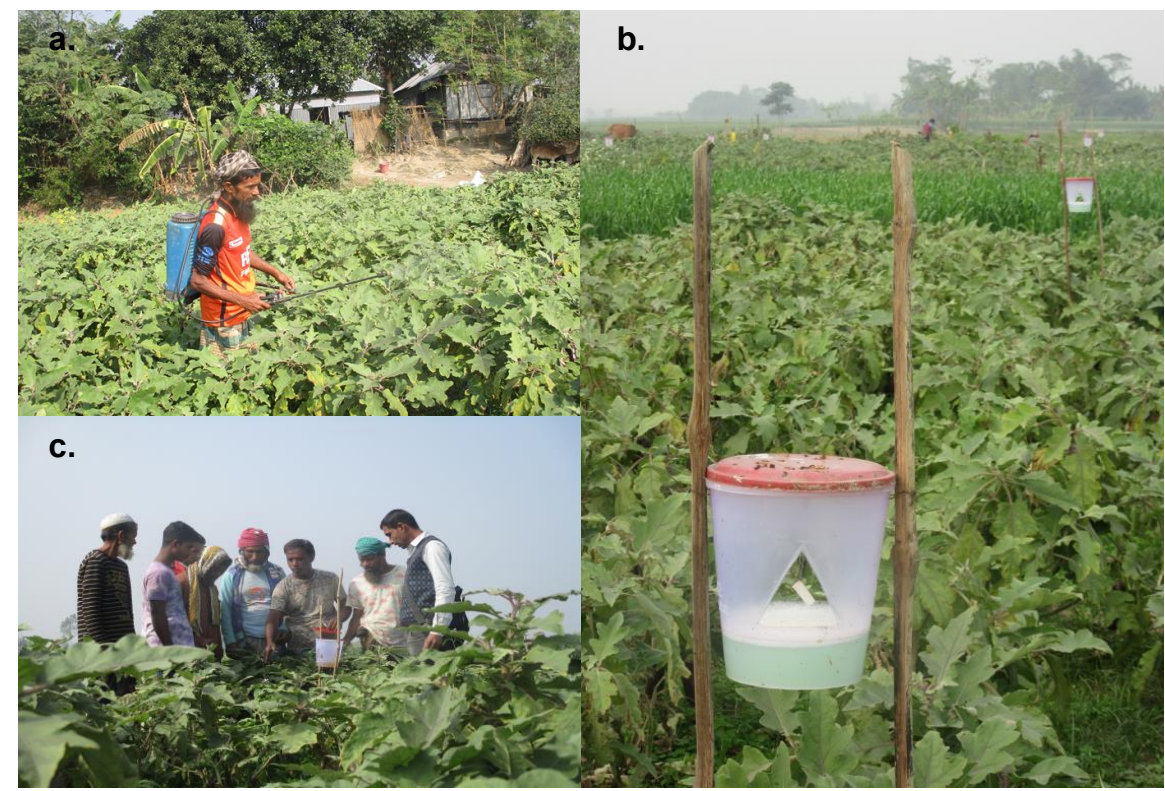

Fig. 1. (a) Farmers usually spray insecticides to control the caterpillars of a moth infesting eggplant shoots and fruits; (b) An alternative practice of mass trapping with pheromone lures is available, in our experiments traps of several adjacent fields formed a network; (c) Field discussions with farmers revealed that they have a poor knowledge of the moth's lifecycle. This restrains their acceptance to limit pest control to traps only, and explains why they are asking also for some spraying.

Another alternative to broad spectrum insecticides is to use so-called biorational insecticides because these have limited or no effect on non-target organisms including natural enemies, birds, and mammals and are therefore considered environmentally friendly (Sarfraz et al. 2005; Rosell et al. 2008). Spinosad, originating from the soil bacterium Saccharopolyspora spinose, is considered an ideal candidate for incorporation in integrated pest management (IPM) because of its selective toxicity and favorable environmental profile (Bret et al. 1997; Sarfraz et al. 2005; Biondi et al. 2012). Spinosad is primarily a stomach poison with some contact, systemic, and transcellular activity and is active especially against a range of Lepidopteran insects and some Diptera, Coleoptera, and Thysanoptera (Bret et al. 1997; Williams et al. 2003). Spinosad is effective against various borers including ESFB (Kalawate and Dethe 2012). However, integration in trap catch-based applications has to our knowledge not yet been attempted in eggplant. 
The Asian Vegetable Research and Development Centre (AVRDC) developed and promoted an IPM strategy for ESFB control for South Asia, including Bangladesh, in 2000-2006 (Alam et al. 2006; Srinivasan 2008). This package was based on sanitation through regular removal of infested shoots and fruits, refraining from insecticides, and installing pheromone traps. A national IPM policy was launched in Bangladesh in 2002, and extension staff were trained to train farmers through IPM farmers' field schools. Despite these efforts, farmers continue to use pesticides and IPM adoption remains low, a phenomenon often observed, particularly in developing countries (Morse and Buhler 1997; Peshin 2013; Parsa et al. 2014). According to Parsa et al. (2014), globally, institutional problems, weak adoption incentives, and outreach problems are important factors limiting adoption. In South and South-East Asia, it is mainly weaknesses in IPM and in IPM research and outreach that limit adoption. IPM is laborintensive, and IPM research does not focus on farmers' needs and lacks participatory approaches (Parsa et al. 2014). Furthermore, IPM research is often focused on technical efficacy, overlooking practical implementation efficacy for target farmers. Moreover, low profitability and high risk or uncertainty are often considered obstacles to IPM adoption (Morse and Buhler 1997; Peshin 2013). A further likely factor for poor adoption is that the major focus in an IPM strategy is on a single major pest rather than on all pests that farmers would like to control (Horne et al. 2008). For example, in Bangladesh, a major production constraint or risk alongside ESFB is bacterial wilt, which can lead to 20-70\% plant loss (Nahar et al. 2019). Therefore, it is important to analyze IPM profitability for ESFB across a range of bacterial wilt levels. Finally, farmers' knowledge level should be considered as a potential constraint to adoption (Litsinger et al. 2009; Peshin 2013; Wyckhuys et al. 2019).

In the present study, we designed experiments together with farmers using available IPM components (pheromone trap, sanitation, biorational insecticide) and compared these improved management options with farmers' conventional practices and no control as reference treatments. This allowed us to assess the technical performance of tested packages for ESFB management, including effects on other pests and natural enemies, and to separately analyze economic viability and practical applicability, taking implementation aspects as possible underlying reasons and rationales for farmers to reject, adopt, or adapt them. 


\section{Chapter 4}

\section{Materials and methods}

\subsection{Study site and farmer selection for the participatory study}

A participatory study on IPM of ESFB was carried out by the first author in Pirijpur village $\left(25^{\circ} 02^{\prime} 13^{\prime \prime} \mathrm{N}-89^{\circ} 50^{\prime} 08^{\prime \prime} \mathrm{E}\right)$, Jamalpur district, the major eggplant growing area of Bangladesh, located in the so-called Old Brahmaputra floodplain. Farmers cultivate eggplants during the cool dry season (Rabi season: September-March). The steps taken to select the study village and participating farmers were as follows: i) focus group discussion with farmers from different upazillas (administrative areas), agricultural officers, scientists from the regional agricultural research station, and NGO representatives, introducing the study and seeking advice on villages worth investigating and ii) transect walks with local extension agents through five villages from two upazillas to assess eggplant cultivation constraints and farmers' interest in research. On the basis of acreage of eggplant cultivation, farmers' interest in getting involved, and accessibility (transport), three villages were shortlisted. After a visit by the first and the last author, Pirijpur was finally selected. In a first formal meeting, the extension agent then formally introduced the first author, who explained the objective of the study and invited farmers to participate in it.

In subsequent village meetings, farmers were selected based on their enthusiasm to join the study, and treatments to be included in the study were negotiated. Besides the initial meeting, monthly meetings were held with participating farmers to understand their view on the research (Fig. 1c). At the end of the experimentation, results were discussed with these farmers. There were also frequent interactions with participating and other curious neighboring farmers during the field work. These discussions were used to assess the practical implementation aspects from farmers' perspectives and possible constraints.

\subsection{Treatment negotiation and experimental design}

The choice of treatments was based on a combination of what the literature indicated as promising as suggested by the first author and what farmers considered as feasible and worth testing. Treatments were negotiated again for year 2 based on year 1 outcomes and insights gained.

\subsubsection{Year 1 (2015-2016)}

Eight farmers participated in the year 1 study. Testing of pheromone trapping (mass trapping through a female sex pheromone lure) either alone or with sanitation (removal of infested shoots and fruits at weekly intervals) was proposed as potential improvements on current farmer management. Six farmers instantly rejected sanitation as too laborious and complex; two 
farmers started but after 1 week dropped it for the aforesaid reasons. Farmers were reluctant to implement pheromone trapping alone, as they considered it risky. Farmers proposed combining trapping with insecticide spraying. Trap-based biorational spraying was then proposed, and advantages of pheromone trapping and biorational were discussed in terms of reduced impact on natural enemies, farmers' health, and the environment. Farmers insisted on also testing conventional spraying while trapping. Consequently, the following treatments were tested by each farmer on his/her fields: (i) pheromone trapping alone, (ii) pheromone trapping combined with trap-based biorational spraying, (iii) pheromone trapping combined with bi-weekly conventional insecticide spraying, (iv) farmers' conventional weekly spraying, and (v) untreated control (for details see below).

Replicates were allocated over the landscape depending on the farmers' land availability. To minimize interference among treated plots and with surrounding fields not included in this study, two rules were applied in allocating treatments to the plots: (1) all participating farmers contributed one plot for each of the five treatments and (2) treatments with and without traps were applied in different fields belonging to the same farmer and as far from one another as possible, at a minimum distance of $100 \mathrm{~m}$. Per farmer, treatments with traps were located as close to one another as possible, preferably in one field divided into $2-3$ treatment plots. In the final layout, fields with pheromone traps formed two clusters, each containing plots of four different farmers, at a distance of $330 \mathrm{~m}$. Thus, the field with pheromone traps formed two networks of nearby plots. Sizes of the pheromone-trap treated plots varied from 400 to $600 \mathrm{~m}^{2}$; farmers' practice plots varied from 256 to $600 \mathrm{~m}^{2}$. Untreated control plots were set at $16 \times 16$ $\mathrm{m}$ to minimize loss of harvest for the farmers. It was agreed that any harvest losses would be compensated.

Soon after transplanting, a single pheromone trap (a plastic container with two opposite triangular openings where a layer of water could be kept in the bottom (Ispahani Biotech, Bangladesh) (Fig. 1b)) was installed in four farmers' fields to monitor moth appearance, observed around 30 days after transplanting (DAT). The number of traps then installed varied according to the size of the trap-treated area, with a minimum of four traps per treatment installed in a $10 \times 10 \mathrm{~m}$ grid, $5 \mathrm{~m}$ from all borders. The traps were mounted on bamboo poles and suspended $10 \mathrm{~cm}$ above the plant canopy. A 4.5-cm layer of water mixed with detergent powder $(0.25 \% \mathrm{w} / \mathrm{v})$ was maintained in the trap. The lure made up of a polyethylene vial impregnated with $0.1 \mathrm{ml}$ of a hexane solution containing $3 \mathrm{mg}$ of $(97 \% \mathrm{w} / \mathrm{w})(\mathrm{E})-11-$ Hexadecenyl acetate (E11-16:Ac) and (E)-11-hexadecen-1-ol (E11-16:OH) was hung from the 


\section{Chapter 4}

plastic lid of the trap by a metal wire, so the lure remained in the middle between the triangular openings of the trap (Fig. 1b). Traps were installed jointly with farmers keeping the triangular openings north and south facing to minimize water evaporation. Lures were replaced every 4 weeks, and farmers changed the water weekly, supervised by the researcher who simultaneously collected moths for counting.

The biorational insecticide Tracer 45 SC (Spinosad) was sprayed at a concentration of 0.4 $\mathrm{mL} / \mathrm{L}$ of water $(200 \mathrm{~mL} / \mathrm{ha})$ between 8.00 and $11.00 \mathrm{~h}$ using a knapsack sprayer. The spray date was guided by the researcher based on trap counts and ESFB lifecycle information. Given the reported lifecycle of the moth (Srinivasan 2008), a first peak of adult moths was expected 1 month after the moth's first appearance in the study area. Trap catches showed substantial increase in the population indeed around 1 month from first catches, and spraying was carried out within a week of the observed increase, taking into account the time needed for egg laying and hatching of $1^{\text {st }}$ instar caterpillars. Subsequent sprays were planned at around 1-month intervals from the first spray. Trap catches were still monitored to assess the next peak in population density, and it was decided that spraying should be carried out when at least on average 4 moths/trap/week were observed. Thus, first spraying occurred at 64 DAT (4 moths/trap/week) and subsequent spraying at 94 DAT (4 moths/trap/week), 130 DAT (10 moths/trap/week), and 159 DAT (15 moths/trap/week), respectively. Although the rationale for timing spraying based on trap catches was discussed with the farmers, it was difficult for farmers to understand. Therefore, in negotiations about the timing of conventional insecticide spraying in combination with trapping, it was decided to apply the first spraying together with the first trap-based biorational spraying at 1 month after the first moths were observed and thereafter at roughly 15 -day intervals. Farmers thus sprayed conventionally at $64,79,94,111$, 130, 146, and 159 DAT. All fields showed a similar pattern of population dynamics, as the fields were close to one another. Therefore, spraying was carried out on the same day for all replicates. In farmer-managed plots, the insecticides chlorpyrifos (48 EC), cypermethrin (10 EC), and malathion (57 EC), alone or in cocktails, were applied weekly at a concentration of each $1.5 \mathrm{~mL} / \mathrm{L}$ of water $(760 \mathrm{~mL} / \mathrm{ha})$ from $20 \mathrm{DAT}$ to the end of the season. The actual dates on which farmers sprayed were recorded.

\subsubsection{Year $2(2016-2017)$}

Nine farmers participated in year 2, seven from the year 1 study and two new farmers. On the basis of the year 1 study, farmers suggested dropping the combination of trapping with conventional spraying as this treatment did not increase yield but killed natural enemies. Fields 
with pheromone trapping formed three clusters at a distance of 115-130 m. Except for this change, the research protocol of year 2 was as in year 1. Based on the same rationale as for year 1, biorational spraying was carried out at 71, 107, 138, and 163 DAT. Farmers sprayed conventionally weekly, as in year 1 . Pheromone treatment plots varied from 400 to $600 \mathrm{~m}^{2}$; farmers' practice plots varied from 256 to $760 \mathrm{~m}^{2}$. Untreated control plots were set at $16 \times 16$ $\mathrm{m}$ to minimize loss of harvest for the farmers.

\subsection{Observations and analyses}

Observations were made in the center of treatment plots at a minimum $5 \mathrm{~m}$ distance from all borders in a $5 \times 5 \mathrm{~m}$ plot within each treatment plot in year 1 and in a $4 \times 4 \mathrm{~m}$ plot in year 2 . Henceforth, these plots are referred to as observation plots to distinguish them from the (larger) treatment plots. The initial number of plants was recorded in each observation plot; plant loss due to bacterial wilt was also recorded, and lost plants were compensated by including plants from rows directly adjacent to the observation plot, thereby gradually increasing the area of the observation plot but keeping a distance from all borders of at least $4 \mathrm{~m}$. From this area, a theoretical total yield and a marketable yield were calculated as if there had been no plant lost to bacterial wilt. Data on plant loss to bacterial wilt were analyzed, and no difference between treatments was found (data not shown). Individual plots differed in level of bacterial wilt though, and, to analyze the pure ESFB effect, a total yield and a marketable yield at the observed average plant loss to bacterial wilt across replicates (27\% in year 1 and $29 \%$ in year 2) are reported.

\subsubsection{Shoot infestation}

Observation plots were monitored weekly to assess initiation of shoot infestation. Shoot infestation data were recorded at 10-day intervals from onset (39 DAT) until it stopped (113 DAT). Thirty randomly picked plants from an average of 55 plants were monitored, ensuring that plants from each row of the observation plot were represented, to count the number of infested shoots. Shoots that were wilted, had holes, or had frass attached were considered infested. A further five random plants per replicate were taken to count the total number of shoots per plant. This was extrapolated to the number of shoots in the sample of 30 plants. Ultimately, the percentage infestation was calculated from the total and the infested number of shoots of 30 plants. 


\section{Chapter 4}

\subsubsection{Fruit infestation and yield}

Eggplants were harvested weekly from observation plots. Healthy and infested eggplants were weighed using a digital scale. Any fruits with holes, frass attached, or a secondary infection (sign of rotting) were considered infested. The percentage of infested fruits was calculated per observation day and plot, and these data were combined in the cumulative infestation.

\subsubsection{Production costs}

Farmers' crop protection activity, the tested potential improved management activities, and material and labor input were recorded. Costs of inputs and sales prices of fruits were also recorded. Sales prices of fruits were used to assess normal average income per kilogram fruit and income per kilogram fruit under low price conditions. Costs of production were considered to include the total costs of all material inputs and hired labor (fertilizers, crop protection products, irrigation, hire of equipment, and labor for tillage) and the labor for crop protection. Labor for crop protection was accounted for separately as this varies with treatments. The own labor for standard practices not related to crop protection such as transplanting, weeding and harvesting was not included in total production costs. Income from all treatments was calculated separately for normal or low sale prices as:

net income $\mathrm{i}_{\mathrm{i}, \mathrm{y}}\left(€ \mathrm{ha}^{-1}\right)=$ marketable yield $\mathrm{i,y}\left(\mathrm{t} \mathrm{ha}^{-1}\right) \times$ price $\left(€ \mathrm{t}^{-1}\right)-\operatorname{cost}_{\mathrm{i}}\left(€ \mathrm{ha}^{-1}\right)$

where subscripts $\mathrm{i}$ and $\mathrm{y}$ refer to treatment and year, respectively. To assess risks for the different treatments relating to observed variability in bacterial wilt losses between years and fields, the breakeven points for investment in different ESFB control strategies and ranges of bacterial wilt were calculated in two steps. Based on a theoretical yield if no plants had been lost to bacterial wilt and a fraction of plants that were lost to bacterial wilt, the net income at any fraction of wilted plants (net income with wilt) is defined by the following:

net income with wilt $\mathrm{i}_{\mathrm{i}, \mathrm{y}}\left(€ \mathrm{ha}^{-1}\right)=$ theoretical yield $_{\mathrm{i}, \mathrm{y}}\left(\mathrm{t} \mathrm{ha}^{-1}\right) \times(1$-fraction wilted plants $) \times$ price $\left(€ \mathrm{t}^{-1}\right)-\operatorname{cost}_{\mathrm{i}}\left(€ \mathrm{ha}^{-1}\right)$

where subscripts $\mathrm{i}$ and $\mathrm{y}$ have the same meaning as above. The net income with wilt at breakeven point is defined as zero, hence at breakeven point:

theoretical yield $\mathrm{i}_{\mathrm{i}, \mathrm{y}}\left(\mathrm{t} \mathrm{ha}^{-1}\right) \times(1$-fraction wilted plants $) \times$ price $\left(€ \mathrm{t}^{-1}\right)=\operatorname{cost}_{\mathrm{i}}\left(€ \mathrm{ha}^{-1}\right)$

The percentage of wilted plants at breakeven point for each treatment $\mathrm{i}$ in year $\mathrm{y}$ can then be calculated as:

$\%$ wilted plants $\mathrm{S}_{\mathrm{i}, \mathrm{y}}=100 \times\left\{1-\left[\operatorname{cost}_{\mathrm{i}, \mathrm{y}}\left(€ \mathrm{ha}^{-1}\right)\right] /\left[\right.\right.$ theoretical yield $\mathrm{i}, \mathrm{y}\left(\mathrm{t} \mathrm{ha}^{-1}\right) \times$ price $\left.\left.\left(€ \mathrm{t}^{-1}\right)\right]\right\}$ 


\subsubsection{Moth counts}

Every week, the numbers of male moths caught per trap per plot were counted. When trapped moths were few, all moths were handpicked by forceps, counted, and discarded. When there were many moths, the water from the trap was poured on muslin cloths, and moths were counted. Traps that were less than $3 \mathrm{~m}$ distance from sprayed plots were eliminated from analysis.

\subsubsection{Counts of natural enemies and sucking insect pests}

Per treatment plot, one yellow sticky trap $(25 \times 10 \mathrm{~cm}$, Horiver, Koppert, Netherlands $)$ was suspended from a bamboo stick $15 \mathrm{~cm}$ above the plant canopy. Sticky traps were changed weekly. Removed sticky traps were carefully wrapped in a transparent, thin polythene sheet and brought to the laboratory for identification to genus level and counting of natural enemies and sucking insects. The number of a selection of natural enemies (ladybird beetle, Trichogramma spp., Bracon spp.) and sucking insects (aphids and jassids) was counted under a magnifying glass and a stereo microscope from 4 of 8 squares on each sticky trap.

\subsubsection{Statistical analyses}

Data were tested for normality and homogeneity of variances using Shapiro-Wilk's and Levene's tests. Only the percentage of fruit infestation and the yield data met these assumptions. These were analyzed using a standard analysis of variance with post-hoc mean separation according to Tukey, using Genstat version 18.0. For all insect counts and percentage shoot infestation, distributions were found non-normal, and therefore models using Poisson, zeroinflated Poisson, and negative-binomial distributions were compared. Given Akaike's information criterion, data on the percentage of shoot infestation and ladybird beetle were found to be best analyzed using a Poisson distribution, whereas Trichogramma spp., Bracon spp., aphids, jassids, and male moths were best analyzed using a negative binomial distribution. These analyses were conducted in R version 64 3.6.1 using the packages: "glmmTMB", "ggplot2", "Rmisc", "MASS", "lsmeans", and "lmtest".

\section{Results and discussion}

The present study aimed to test a number of improved practices for the integrated management of eggplant shoot and fruit borer (L. orbonalis; ESFB), together with smallholder eggplant farmers, to separately analyze the technical efficacy, economic viability, and practical applicability of these practices and assess the chance of adoption. In brief, pheromone trapping 


\section{Chapter 4}

alone reduced shoot and fruit infestation and increased marketable yield and income compared to current farmers' practice (Fig. 2a, b, c, and d; Table 1). Combining pheromone trapping with trap-catch-based spraying of the biorational Spinosad provided further reduction of shoot and fruit infestation, and increased farmers' marketable yield and income. Farmers' practice neither reduced infestation nor increased yield. However, compared to the untreated control, it drastically reduced natural enemies: predatory ladybird beetles (Coccinella septempunctata, Harmonia axyridis, Menochilus sexmaculatus) and parasitoids (Trichogramma spp. and Bracon spp.). In contrast, pheromone trapping alone or with biorational insecticides did not affect natural enemies compared with the untreated control. Limited use of biorational insecticides reduced jassids (Amrasca biguttula biguttula) and aphids (Aphis gossypii) comparably to the more frequent conventional insecticide application under farmers' practice, whereas these pest populations were comparable and higher with pheromone trapping alone and in the untreated control. In terms of economic feasibility, pheromone trapping alone required less labor and cash input than farmers' practice. Adding biorational insecticide slightly increased costs compared with farmers' practice but increased income more. While experimenting, farmers rejected two IPM components: (i) removal of infested shoots and fruits at regular intervals, because it was too labor-demanding and (ii) combining conventional insecticides with trapping because in this case, they argued insecticide did not reduce ESFB while costing money and reducing natural enemies. During joint experimentation, discussing with farmers formally and interacting with them in the fields, we found that farmers had difficulty understanding the ESFB lifecycle and the pheromone trapping mechanism.

Below, an elaboration follows along the same lines: (i) technical efficacy, (ii) economic viability, and (iii) practical applicability of the tested improved IPM.

\subsection{Technical efficacy of the tested IPM}

\subsubsection{Shoot and fruit infestation}

Shoot infestation started around 40 DAT (days after transplanting) and continued up to 100 115 DAT (Fig. 2). From the onset of fruiting (60 DAT), caterpillars switched to fruit infestation, and this increased up to final harvest (185 DAT).

In both years, the two-way interaction between pest management and observation dates on percentage shoot infestation was significant $(p<0.001)$, as differences between treatments were limited, when overall infestation levels were low before 60 DAT and after 80 DAT (year 1) to 100 DAT (year 2) (Fig. 2a, b). When shoot infestation levels were higher, the effect of pest management treatments became significant. Pheromone traps kept shoot infestations below 3 
(year 1) to 6\% (year 2), roughly half the levels observed under farmers' practice. The addition of conventional spraying to pheromone trapping tested in year 1 did not provide additional control; the addition of limited biorational spraying provided a slight but significant additional control in both years during peak infestation. Compared with not spraying at all, the farmers' practice of regular spraying did not provide any significant control except in year 2 at 95 DAT when a limited control of 5 percentage points lower shoot infestation was observed compared with the untreated control (14\% versus 19\%) (Fig. 2a, b).

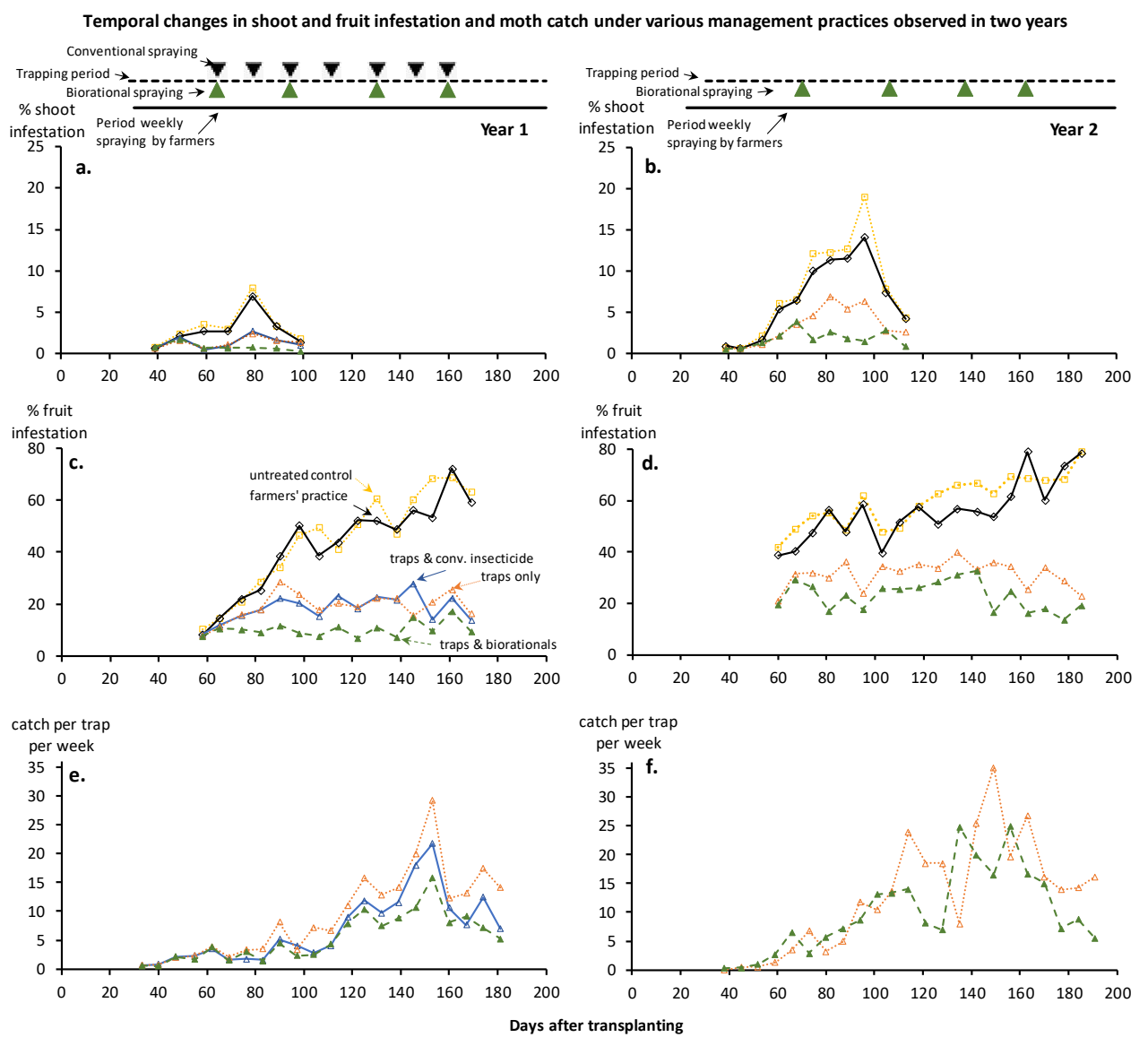

Fig. 2. Percent shoot $(a, b)$ and fruit $(c, d)$ infestation and number of trapped male moths (e, f) over the two experimental seasons, moth counts only where traps were installed. Periods of trapping and farmers' practice spraying and the days of biorational and conventional spraying (latter year 1 only) are indicated per year at the top of the figure. At most dates, infestations were higher for the untreated control and farmers' practice plots than for the plots where traps were installed. Trapping alone or with conventional spraying (year 1 only) showed comparable infestation, and this was mostly higher than trapping accompanied by spraying biorational insecticide. 


\section{Chapter 4}

In both years, the interaction between pest management and observation dates on fruit infestation was also significant $(p<0.001)$. Improved management provided better protection (10-58 percentage point lower fruit infestation) throughout the whole fruiting period (60-185 DAT) compared with farmers' conventional spraying (Fig. 2c, d). At the peak fruiting period (90-150 DAT), improved practices reduced fruit infestation by $28-44$ percentage point compared with farmers' practice. The addition of conventional spraying to pheromone trapping did not provide additional control; hence, farmers proposed dropping this treatment in the second year. However, adding biorational insecticide spraying to pheromone trapping provided an additional reduction in infestation (9-15 percentage point). Compared with the untreated control, the weekly spraying under farmers' practice did not systematically reduce infestation; under farmers' practice, only at two to three random dates was a limited reduction in fruit infestation by $2-12$ percentage point observed in both years (Fig. 2c, d).

The notable difference in effect on ESFB infestation between the 18 to 21 times spraying under farmers' practice and the 4 times biorational application (Fig. 2) is most likely caused by a combination of factors, including the very short period between hatching and the $1^{\text {st }}$ instar larvae entering shoots or fruits (Hanur et al. 2014), which provided a very narrow margin for control by the applied contact insecticides. Biorational spraying targeted the peak numbers in this life stage. Furthermore, insects might have developed resistance due to repeated insecticide use (Alam et al. 2006; Srinivasan 2008; Rahman and Rahman 2009). The trap-catch-based spraying of the biorational optimally targeted an expected peak in eggs and $1^{\text {st }}$ instar larvae, as the applied Spinosad generally also kills the insect through contact and ingestion, although local systemic action through transcellular movement has also been reported (Williams et al. 2003; Van Leeuwen et al. 2005; Weintraub and Mujica 2006). Spinosad affected the moth population locally, because the number of moths per trap per week was reduced in Spinosad-treated plots compared with the adjacent plots with only pheromone traps or with conventional insecticide spraying (Fig. 2e, f).

\subsubsection{Populations of ESFB male moths, natural enemies and sucking insects}

For insect counts (ESFB moths, natural enemies, and sucking insects), the interaction between pest management treatments and observation dates was significant $(p<0.001)$ in half of the cases; when the interaction was not significant, both time and treatment effects were. When significant, the interactions were always the consequence of no significant differences when few insects of a species were observed; when a species was more abundant, differences were always significant. In both years, adding biorational spraying to pheromone trapping 
significantly reduced the peak numbers of male ESFB moths compared with pheromone trapping alone (Fig. 2e, f). The conventional spraying at times also reduced the moth populations slightly (Fig. 2e, f), but this did not translate into lower fruit infestations or higher yield, as reported above. The dynamics over time in male moth catches are obviously only available from pheromone-trapped plots. The population built up from nearly 90 DAT (December) and gradually increased up to 170 DAT (March). A first peak in the population was end of December at 90 DAT, roughly 1 month after the first appearance had been observed and thereafter again at 1-month intervals: 130 DAT (end of January), 150 DAT (end of February), and 170 DAT (end of March) for both study years (Fig. 2e, f). This corresponds more or less to the reported 1-month lifecycle (Srinivasan 2008).
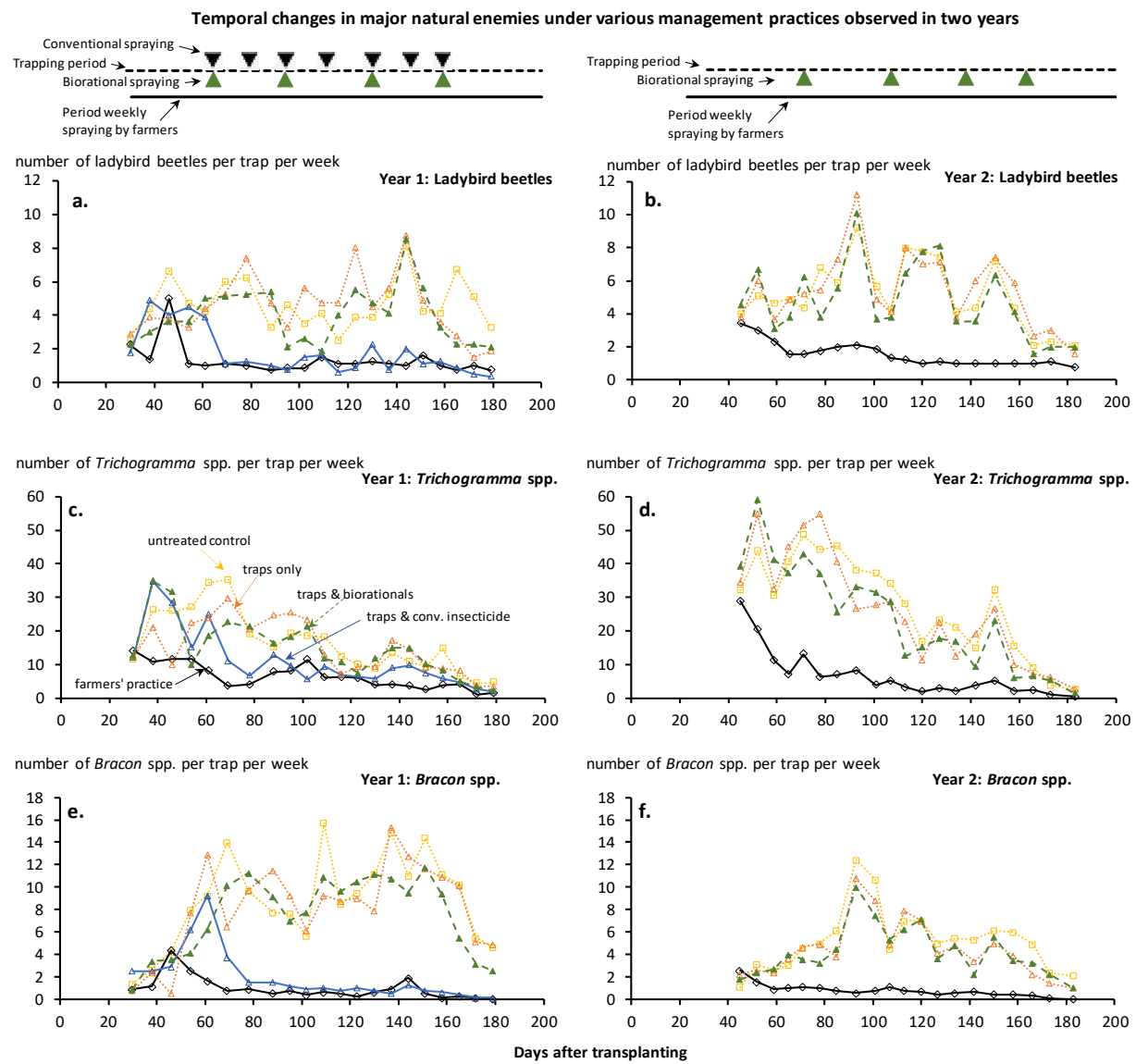

Fig. 3. Numbers of three major natural enemies: ladybird beetles (a, b), Trichogramma spp. (c, d), and Bracon spp. (e, f) over the two experimental seasons. Periods of trapping and farmers' practice spraying and the days of biorational and conventional spraying (latter year 1 only) are indicated per year at the top of the figure. At most dates, numbers of natural enemies were lower for the farmers' practice plots and plots where conventional insecticide spraying was combined with pheromone traps than for plots that were not sprayed or where the biorational insecticide was sprayed. 


\section{Chapter 4}

In both years, on most observation dates, the numbers of the observed predatory ladybird beetle complex (Coccinella septempunctata, Harmonia axyridis, Menochilus sexmaculatus) and parasitoids (Trichogramma spp. and Bracon spp.) were drastically reduced in farmers' practice plots compared to plots with pheromone trapping alone or combined with biorational spraying (Fig. 3). When conventional insecticide was sprayed on pheromone-trapped plots, a substantial reduction in all natural enemies was also observed, and numbers of natural enemies on these plots were comparable with numbers on farmers' practice plots. In contrast, the initial drop in the number of natural enemies after biorational spraying was always followed by a population recovery within 1 to 2 weeks. Numbers of natural enemies in pheromone-onlytrapped plots were comparable with those in untreated control plots. The observed effects are in line with a study by Hill et al. (2017) reporting that organophosphates, particularly chlorpyrifos, drastically reduced arthropod natural enemy densities in the field. Even one or two applications in year 1 in plots combining the conventional insecticide with pheromone trapping largely killed the natural enemies and ultimately kept them at low abundance throughout the season (Fig. 3). Therefore, farmers' practice might be deprived of natural insect control. The reported natural enemies are not specific to ESFB; therefore, their reduction also compromises pest control of adjacent or succeeding crops. In our study, the number of natural enemies dropped right after spraying (Fig. 3) but recovered within a week, as observed earlier for Trichogramma populations (Scholz and Zalucki 2000). This short-lived effect of Spinosad on natural enemies may also be partly related to the trap-catch-based spraying that reduced the number of sprays. Our results are also in agreement with Liu et al. (2016), who reported that Spinosad did not affect predators and parasitoids of Spodoptera exigua, and studies reporting Spinosad to be mostly not harmful to predators, especially Coleopterans (Williams et al. 2003; Galvan et al. 2005), although other studies reported that Spinosad reduced the number of parasitoids (reviewed in Biondi et al. 2012).

In both years, the populations of sucking insect complexes - jassids (mainly Amrasca biguttula biguttula) and aphids (mainly Aphis gossypii) - remained lowest in plots where pheromone traps were combined with limited use of biorational insecticides (Fig. 4). Farmers' practice limited these sucking insect species to levels comparable to those for biorational spraying. Numbers observed in untreated control plots and pheromone-only-trapped plots were highest and comparable (Fig. 4). Our data do not allow assessment of whether these levels of jassids and aphids reduced yield. If sucking insects develop beyond this level, they might have higher impact on yield; in that case, farmers may revert to using insecticides in addition to 
trapping. This reversion to spraying could be a pitfall of IPM. In the present study, adding a biorational reduced such a risk, as this cost-effectively reduced ESFB and controlled aphids and jassids.
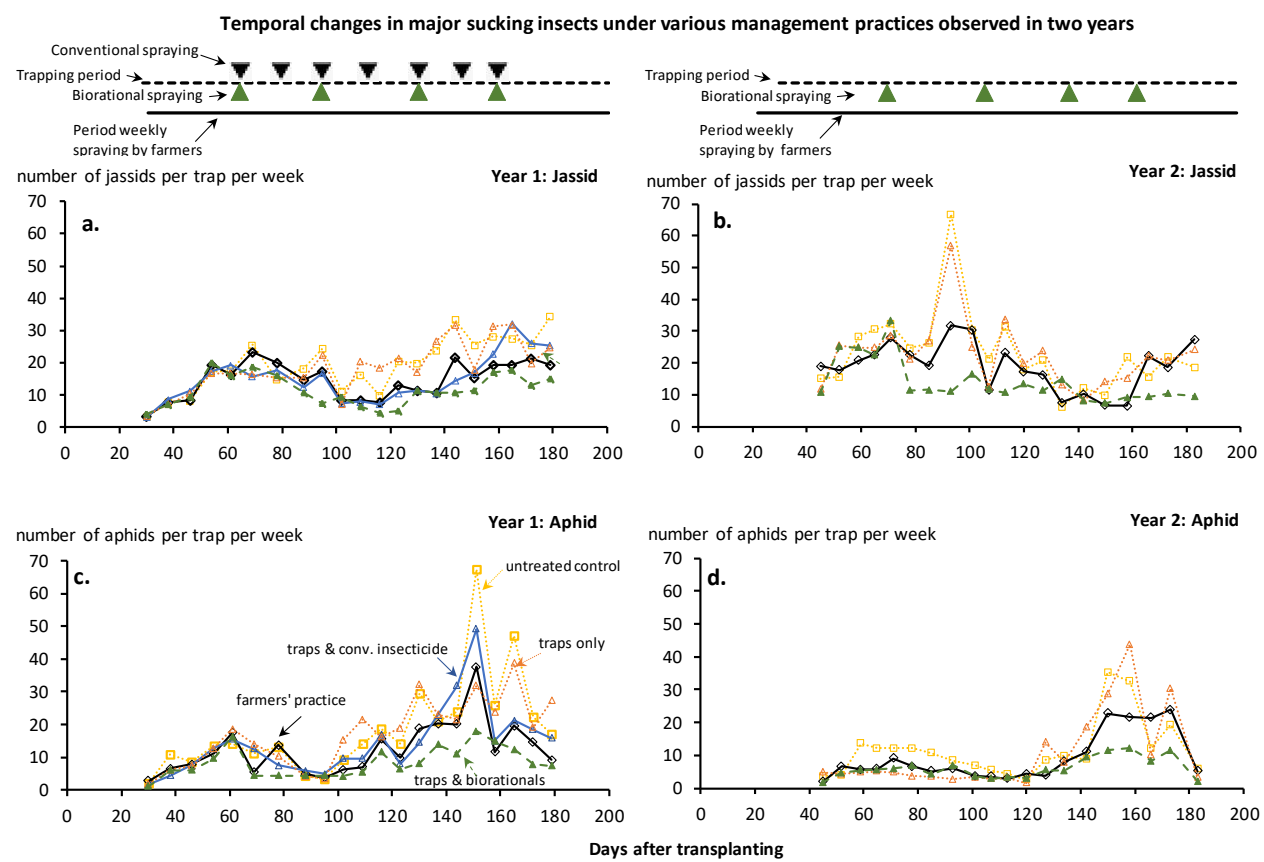

Fig. 4. Numbers of the two major sucking insects, jassids (a, b), and aphids (c, d) trapped by sticky traps per week over the two experimental seasons. Periods of trapping and farmers' spraying practice and the days of biorational and conventional spraying (latter year 1 only) are indicated per year at the top of the figure. Numbers of major sucking insects were lower on most dates for plots where the biorational insecticide was sprayed than for plots that were not sprayed or where only traps were used. Farmers' conventional spraying also reduced their numbers on some dates.

\subsection{Economic viability of the tested IPM}

The highest marketable yield was, in both years, obtained when pheromone trapping was accompanied by 4 times trap-based spraying of a biorational insecticide (Table 1). This yield was 12-14 t ha-1 higher than farmers' conventional practice or the no treatment control, which were not significantly different. Pheromone trapping alone yielded $8-9 \mathrm{t} \mathrm{ha}^{-1}$ more than farmers' practice. Yields from pheromone trapping alone or combined with conventional insecticide spraying were comparable. The difference between the net value of the harvest with improved management and that with farmers' practice demonstrates an obvious advantage of IPM over farmers' current practice (Table 1). Across the 2 years, it appeared that, by practicing improved management, farmers could earn $€ 1300-1800 \mathrm{ha}^{-1}$ more in years when eggplant prices were 


\section{Chapter 4}

normal, but still $€ 900-1200$ ha $^{-1}$ more in years with low prices, compared to their current practice (Table 1). If farmers installed only pheromone traps they could, depending on eggplant prices, earn $€ 1390 \mathrm{ha}^{-1}$ to $€ 980 \mathrm{ha}^{-1}$ more than their current practice, at roughly $45 \%$ of the cost of their conventional practice. In year 1, combining conventional insecticides with pheromone trapping reduced income. Therefore, because of proposals from the involved farmers, this practice was not repeated in year 2. However, farmers might earn a further additional net $€ 392$ $\mathrm{ha}^{-1}$ in years with normal prices and $€ 176 \mathrm{ha}^{-1}$ in years with low prices if they combined biorational insecticide spraying with pheromone trapping (Table 1) compared to only installing pheromone traps, but at substantial extra costs. Interestingly, farmers could gain $€ 420 \mathrm{ha}^{-1}$ by taking no insect protection actions compared to their current practices, simply because costs would be reduced. The costs of farmers' practice over doing nothing were $€ 485 \mathrm{ha}^{-1}$, pheromone trapping costs $€ 200$ ha $^{-1}$ less than farmers' practice, costs of combining pheromone trapping and trap-based limited spraying of biorational insecticide were comparable with farmers' practice; however, the aforesaid improved practices led to $€ 1300-1800 \mathrm{ha}^{-1}$ more income. The investment in pheromone trapping of $€ 280 \mathrm{ha}^{-1}$ provided a net extra income of between $€ 530$ and $€ 970$ ha $^{-1}$ compared to the untreated control, depending on the eggplant price. For farmers, who currently invest $€ 485 \mathrm{ha}^{-1}$ on insecticides at no profit, this investment should be feasible. This provides evidence that farmers' practice is not based on an assessment of costs and benefits.

Besides insect pests, a major production challenge in the area is bacterial wilt, observed to lead to between 20 and 70\% plant loss (Nahar et al. 2019). On average, the experimental fields suffered $27-29 \%$ plant loss to bacterial wilt. There is a risk of investment in ESFB IPM being lost due to plant loss through bacterial wilt, a point raised by farmers when negotiating the present study; they stated "what if we do not have plants, where will we implement IPM for ESFB?" (Table 2). Indeed, farmers are not interested in a single-problem-oriented IPM when one problem constrains another economically (Horne et al. 2008; Parsa et al. 2014). We therefore used a simple model to assess breakeven points of different IPM options and found that pheromone trapping provided a positive income at plant loss to bacterial wilt of up to 5962 or $73-75 \%$ in years with low or normal eggplant prices, respectively, well above the breakeven points of $27-38$ to $52-60 \%$ for farmers' practice (Table 1). Therefore, the risk of a negative income is much lower when pheromone traps are used either alone or combined with biorational insecticides than with current farmers' practice. 


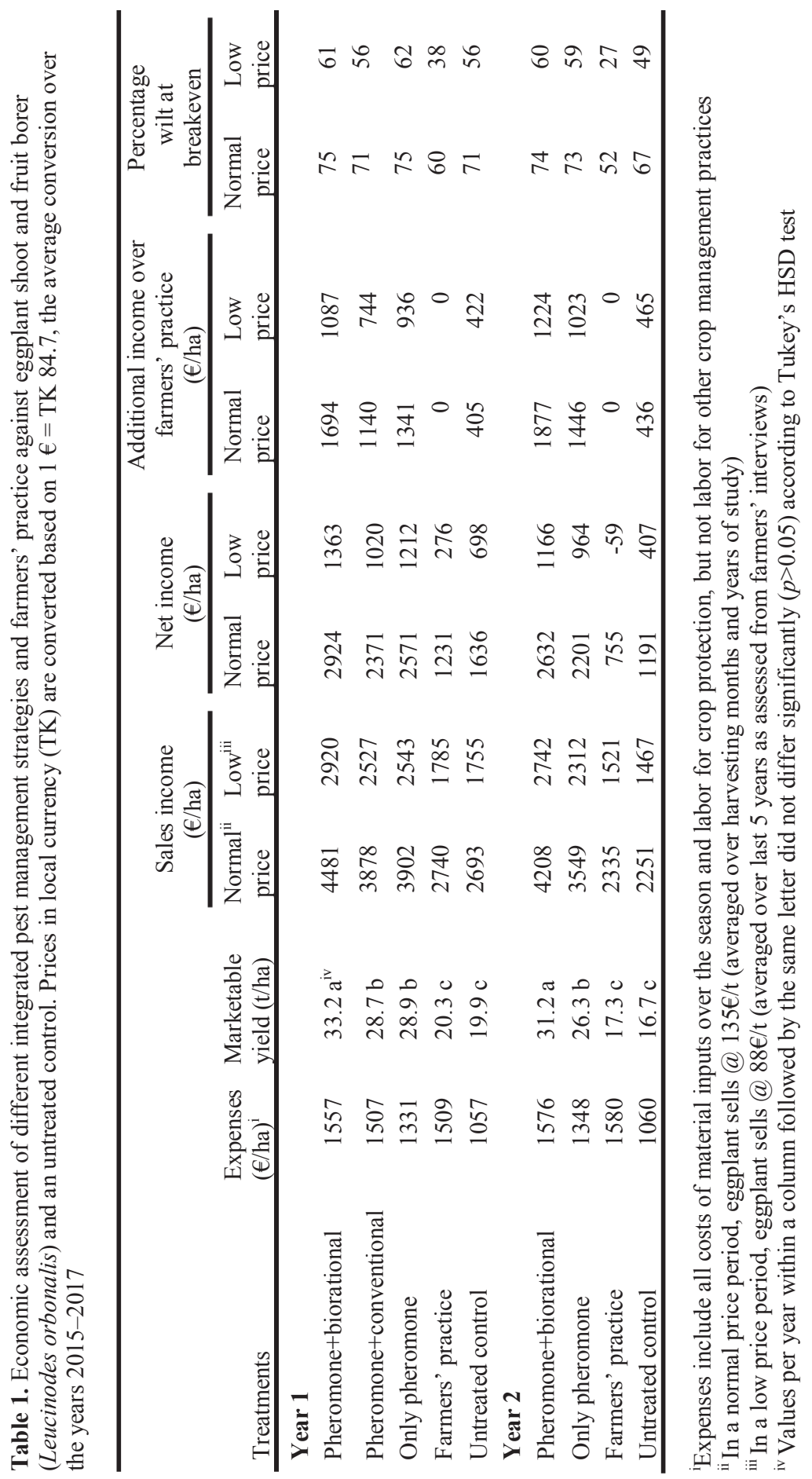




\section{Chapter 4}

\subsection{Practical applicability of the tested IPM}

From the beginning to the end of the study, during negotiations, monthly discussions, and joint field observations, we recorded farmers' reactions to, and observations on, different aspects of the studied IPM options. Only the most telling quotes are presented here (Table 2). We identified four major bottlenecks in the tested IPM options: (i) farmers' knowledge on ESFB biology is partial at best, as they could not relate caterpillars and adult moths; (ii) traps and lures are not yet available at village level; (iii) farmers are not in favor of labor-adding practices and thus rejected sanitation; (iv) farmers questioned the efficacy of IPM if traps are not installed in a network of farmers' fields as in the present study, but installed in individual fields.

During initial discussions, farmers indicated that they were familiar with pheromone trapping because previously there had been a farmers' field school training in the village. However, when asked what would be caught in traps, they answered keera (caterpillar). Soon after the first trap catches, farmers wondered why "strange flies" were caught instead of the caterpillars damaging their crops. When asked about the fate of caterpillars, they answered "caterpillar rots inside fruit". Apparently, farmers had difficulty understanding the ESFB lifecycle. Therefore, farmers' knowledge could be a fundamental constraint to IPM implementation (Litsinger et al. 2009). Correct farmers' knowledge on insect biology and ecology is an important component to make strategic IPM successful. Without it, farmers will expect little benefit from these traps. Successful adoption requires knowledge on how to correctly implement the practice and what to expect from it, not just on the practice itself. However, even if that knowledge is improved now, the availability of IPM materials such as traps, pheromone lures, and biorational insecticides is limited in the study area, whereas farmers can buy broad spectrum insecticides on their doorstep. If these inputs are not made more readily available to farmers, the continued practice of improved IPM is likely to be negligible. During negotiations about improved management, the proposed removal of infested shoots and fruits as previously recommended by Alam et al. (2006) was immediately rejected. Indeed, IPM requiring more labor is unlikely to succeed (Beckmann and Wesseler 2003). Our results can be aligned with the findings of Peshin (2013), who reported that cotton IPM farmers in India strongly adopted timely sowing as it is simple, requiring no extra labor; on the other hand, monitoring insects for economic threshold level was poorly adopted because it required skill and labor. Therefore, if we want farmers to implement IPM, we need to think rationally about farmers' how-to-do knowledge, skills, labor, and availability of IPM materials. 
In the present study, fields of participating farmers made a network of nearby traps because of the extent of the study. In other words, this study shows that, as a trapping network, pheromone traps reduced shoot and fruit infestation and increased yield. We have not yet answered the question of whether trapping also works when a small landholder installs it in an individual field. This was also the concern of farmers who stated: "I think that the trap will attract more insects if I am alone" (Table 2).

Table 2. Summary of selected statements made by farmers during the study and the context in which these were made

\begin{tabular}{|c|c|}
\hline Statement & Context \\
\hline $\begin{array}{l}\text { "Whenever we see infested shoots or } \\
\text { fruits, we remove them. We are } \\
\text { practicing this from our fathers' time. } \\
\text { We cannot do it weekly or regularly as } \\
\text { structured practice, we do not have time } \\
\text { for that." }\end{array}$ & $\begin{array}{l}\text { During a negotiation meeting where we decided which improved } \\
\text { practices would be tested in the field, it was suggested that farmers } \\
\text { remove infested shoots and fruits as a practice. Most of the farmers } \\
\text { immediately rejected the proposal. Two farmers did it once, and after } \\
\text { that they reported it was too time consuming and laborious. } \\
\text { Therefore, they decided not to practice it anymore. }\end{array}$ \\
\hline $\begin{array}{l}\text { "What is inside the shoots and fruits is } \\
\text { not in the traps. Traps catch flies only. } \\
\text { Flies are not problem to us." }\end{array}$ & $\begin{array}{l}\text { When pheromone trapping was proposed to farmers, most of them } \\
\text { said that they knew about traps but that they catch morphs other than } \\
\text { caterpillars. Farmers were confused by trap catches (whether it was } \\
\text { some kind of fly or ESFB adults as described by the researcher) until } \\
\text { the infestation became stabilized. One farmer attempted to remove } \\
\text { traps at the beginning of the field study. }\end{array}$ \\
\hline "Keera (caterpillar) rots inside fruits." & $\begin{array}{l}\text { When farmers were asked about the caterpillars' lifecycle, they } \\
\text { could not answer how caterpillars are born and how they develop. }\end{array}$ \\
\hline $\begin{array}{l}\text { "We cannot kill them even if we spray } \\
\text { regularly. How could you tell us not to } \\
\text { spray?" }\end{array}$ & This was a response when only pheromone trapping was proposed. \\
\hline $\begin{array}{l}\text { "If we don't have plants, where will we } \\
\text { apply ESFB IPM?" }\end{array}$ & $\begin{array}{l}\text { Every year, farmers' fields suffer from bacterial wilt. Farmers } \\
\text { indicated that just working on an ESFB IPM was not that relevant to } \\
\text { them. }\end{array}$ \\
\hline $\begin{array}{l}\text { "I think I will attract more insects if I am } \\
\text { the only person in the landscape with } \\
\text { traps." "I think that the trap will attract } \\
\text { more insects if I am alone." }\end{array}$ & $\begin{array}{l}\text { Farmers expressed their worry about using traps at individual level. } \\
\text { They think that they will have more insects in their fields if they are } \\
\text { the only one using traps. }\end{array}$ \\
\hline
\end{tabular}




\section{Chapter 4}

\section{Conclusion}

The present study tested an array of options with farmers. From a technical perspective, pheromone trapping alone or in combination with limited biorational spraying can improve marketable yields and farmers' income at comparable input costs in terms of cash and labor. Therefore, farmers can either choose only pheromone trapping or add biorational spraying to trapping. We recommended and supervised firstly single trap monitoring on a few plots, followed by the installation of traps for mass trapping after the first moths were trapped 25-30 DAT. Although we did not research the extent to which infestation would be reduced if traps were installed at flowering or fruiting stage, data on population dynamics (Fig. 2e, f) support the decision to avoid risks of substantial damage by waiting for longer than the first observations of moths in traps. Use of only pheromone trapping and refraining from insecticide use would be challenging for farmers currently used to calendar-based spraying (Morse 2009). Therefore, a combination of trapping with limited biorational spraying as a fallback option could increase the chance of adoption. This would also provide control if sucking insect populations got out of hand and thereby alleviate the risk of failure to introduce the new regime. However, in this study, the timing of biorational spraying was guided by the researcher. Only with more training may farmers independently be able to decide when to spray based on trapcatch monitoring. Alternatively, farmers could be instructed to spray biorational insecticide at roughly 30-35-day intervals from the moment of first moth appearance to target eggs and $1^{\text {st }}$ instar caterpillars. In addition, a critical level of 4 moths per trap per week could be introduced as the level above which spraying may be useful.

Although farmers stated that managing traps was not more difficult and time consuming than conventional spraying, from a practical implementation perspective, given farmers' contexts, two major constraints were observed: (i) farmers' ability to comprehend the moth's lifecycle and the trapping mechanism; (ii) unavailability of pheromone lures, traps, and biorationals at village level. Without at least addressing these constraints, IPM implementation will not succeed.

To the best of our knowledge, this is the first study to disentangle the technical efficacy and the economic viability of pheromone-trap-based IPM from its practical applicability for the targeted smallholder vegetable growers. It allowed us not only to identify best options for and with farmers, but also to assess the underlying complexity of making IPM work for smallholder eggplant growers. This study was conducted in Bangladesh, but the findings on practical constraints are most likely valid across South and South-East Asia where the same pest is a 
major problem and smallholders' knowledge levels and farming conditions are comparable. This provides a novel insight for IPM researchers on the underlying complexity of IPM and the research approach that could help in designing workable approaches with farmers.

From the observations and discussions in the field, we propose to study further: (i) whether results would be different when traps are not installed as a network as tested in the present study and consequently what density of trapping is needed to manage ESFB and whether this requires community-level organization; (ii) whether the involved farmers retain or abandon the tested IPM and also whether it spreads among other farmers in the same village; (iii) whether participant farmers' knowledge on ESFB biology and pheromone trapping improves.

\section{Acknowledgments}

This project was funded by NUFFIC (The Dutch Organization for Internationalization in Education), The Netherlands, under its NICHE program (grant number NUFFIC-NICHE-BGD156), a collaboration between Wageningen University and Research (WUR) and Bangladesh Agricultural University (BAU). We acknowledge Pirijpur farmers for participating in the study and allocating land to tests, the farmer trainers for assistance in the study, the villagers for their cooperation, and IPM laboratory of the Department of Entomology (BAU) for identifying natural enemies. We also acknowledge Bob Douma, Assistant Professor at WUR, for his support in the statistical analysis and Catherine O'Dea Hughes for language editing.

\section{References}

Alam SN, Hossain MI, Rouf FMA, Jhala RC, Patel MG, Rath LK, Sengupta A, Baral K, Shylesha AN, Satpathy S, Shivalingaswamy TM, Cork A, Talekar NS (2006) Implementation and promotion of an IPM strategy for control of eggplant fruit and shoot borer in South Asia. Technical bulletin no. 36. AVRDC publication number 06-672. AVRDC - the world vegetable center, Shanhua, Taiwan.

Beckmann V, Wesseler J (2003) How labour organization may affect technology adoption: an analytical framework analyzing the case of integrated pest management. Environ Dev Econ 8:437-450. https://doi.org/10.1017/s1355770x0300238

Biondi A, Mommaerts V, Smagghe G, Vinuela E, Zappala L, Desneux N (2012) The non-target impact of spinosyns on beneficial arthropods. Pest Manag Sci 68:1523-1536. https://doi.org/10.1002/ps.3396

Bret BL, Larson LL, Schoonover JR, Sparks TC, Thompson GD (1997) Biological properties of Spinosad. Down Earth 52:6-13. 


\section{Chapter 4}

Chowdhury MA, Fakhruddin AN, Islam MN, Moniruzzaman M, Gan SH, Alam MK (2013) Detection of the residues of nineteen pesticides in fresh vegetable samples using gas chromatographymass spectrometry. Food Control 34:457-465. https://doi.org/10.1016/j.foodcont.2013.05.006

Cork A, Alam SN, Das A, Das CS, Ghosh GC, Farman DI, Hall DR, Maslen NR, Vedham K, Phythian SJ, Rouf FM (2001) Female sex pheromone of brinjal fruit and shoot borer, Leucinodes orbonalis blend optimization. J Chem Ecol 27 (9):1867-1877.

Cruz I, Figueiredo MD, Silva RB, Silva IF, Paula CD, Foster JE (2012) Using sex pheromone traps in the decision-making process for pesticide application against fall armyworm (Spodoptera frugiperda [Smith] [Lepidoptera: Noctuidae]) larvae in maize. Int J Pest Manage 58:83-90. https://doi.org/10.1080/09670874.2012.655702

El-Sayed AM, Suckling DM, Wearing CH, Byers JA (2006) Potential of mass trapping for long-term pest management and eradication of invasive species. J Econ Entomol 99:1550-1564. https://doi.org/10.1093/jee/99.5.1550

Galvan TL, Koch RL, Hutchinson WD (2005) Toxicity of commonly used insecticides in sweet corn and soybean to multicolored Asian lady beetle (Coleoptera: Coccinellidae). J Econ Entomol 98 (3):780-789.

Hanur VS, Boopal K, Arya VV, Srividya KN, Saraswathi MS (2014) Why is management of brinjal shoot and fruit borer, Leucinodes orbonalis Guenee, difficult? An examination into the pest's unique feeding behavioral biology. J Entomol Zoology Stud 2 (6):257-260.

Hill MP, Macfadyen S, Nash MA (2017) Broad spectrum pesticide application alters natural enemy communities and may facilitate secondary pest outbreaks. PeerJ 5:4179. https://doi.org/10.7717/peerj.4179

Horne PA, Page J, Nicholson C (2008) When will integrated pest management strategies be adopted? Example of the development and implementation of integrated pest management strategies in cropping systems in Victoria. Aust J Exp Agric 48:1601-1607. https://doi.org/10.1071/ea08072

Kalawate A, Dethe MD (2012) Bioefficacy study of biorational insecticide on brinjal. J Biopestic 5 (1):75-80.

Litsinger JA, Libetario EM, Canapi BL (2009) Eliciting Farmer Knowledge, Attitudes, and Practices in the Development of Integrated Pest Management Programs for Rice in Asia. In: Peshin R, Dhawan AK (eds) Integrated Pest Management: Dissemination and Impact. Springer, Dordrecht, pp. 119-273. https://doi.org/10.1007/978-1-4020-8990-9_5

Liu Y, Li X, Zhou C, Liu F, Mu W (2016) Toxicity of nine insecticides on four natural enemies of Spodoptera exigua. Sci Rep 6:39060. https://doi.org/10.1038/srep39060

Miah SJ, Hoque A, Paul A, Rahman A (2014) Unsafe use of pesticide and its impact on health of farmers: a case study in Burichong Upazila, Bangladesh. J Environ Sci Toxicol Food Technol 8:57-67. https://doi.org/10.9790/2402-08155767

Mohiuddin M, Hossain MM, Rahman AK, Palash MS (2009) Socio-economic study of insecticide use on vegetable cultivation at farm level in Chittagong region. J Bangl Agric Univ 7:343-350. https://doi.org/10.3329/jbau.v7i2.4745 
Morse S (2009) Chapter 36 - IPM: Ideals and Realities in Developing Countries. In: Radcliffe EB, Hutchison WD Cancelado, RE (eds) Integrated Pest Management: Concepts, Tactics, Strategies and Case Studies. Cambridge University Press, pp. 458-470. https://doi.org/10.1017/cbo9780511626463.037

Morse S, Buhler W (1997) IPM in developing countries: the danger of an ideal. Integr Pest Manage Rev 2:175-185.

Nahar N, Islam MR, Uddin MM, de Jong P, Struik PC, Stomph TJ (2019) Disease management in eggplant (Solanum melongena L.) nurseries also reduces wilt and fruit rot in subsequent plantings: a participatory testing in Bangladesh. Crop Prot 120:113-124. https://doi.org/10.1016/j.cropro.2019.02.018

Parsa S, Morse S, Bonifacio A, Chancellor TC, Condori B, Crespo-Pérez V, Hobbs SL, Kroschel J, Ba MN, Rebaudo F, Sherwood SG (2014) Obstacles to integrated pest management adoption in developing countries. Proc Natl Acad Sci USA 111:3889-3894. https://doi.org/10.1073/pnas.1312693111

Peshin R (2013) Farmers' adoptability of integrated pest management of cotton revealed by a new methodology. Agron Sustain Dev 33:563-572. https://doi.org/10.1007/s13593-012-0127-4

Pimentel D (1995) Amounts of pesticides reaching target pests: environmental impacts and ethics. J Agric Environ Ethics 8:17-29. https://doi.org/10.1007/bf02286399

Rahman MM, Rahman MM (2009) Study on the development of resistance in brinjal shoot and fruit borer against different insecticides. World J Zool 4 (2):137-143.

Rosell G, Quero C, Coll J, Guerrero A (2008) Biorational insecticides in pest management. J Pestic Sci 33 (2):103-121.

Ruberson J, Nemoto H, Hirose Y (1998) Chapter 11: Pesticides and Conservation of Natural Enemies in Pest Management. In: Barbosa P (eds) Conservation Biological Control. Academic Press, pp. 207-220. https://doi.org/10.1016/b978-012078147-8/50057-8

Sarfraz M, Dosdall LM, Keddie BA (2005) Spinosad: a promising tool for integrated pest management. Outlooks Pest Manage 16:78-84. https://doi.org/10.1564/16ap109

Scholz BC, Zalucki MP (2000) The effects of Two New Insecticides on the Survival of Adult Trichogramma pretiosum Riley in Sweet Corn. In: Austin AD, Dowton M (eds) Hymenoptera: Evolution, Biodiversity and Biological Control. CSIRO Publishing, Canberra, pp. 381-387.

Srinivasan R (2008) Integrated pest management for eggplant fruit and shoot borer (Leucinodes orbonalis) in south and Southeast Asia: past, present and future. J Biopestic 1 (2):105-112.

Van Leeuwen T, Dermauw W, Van De Veire M, Tirry L (2005) Systemic use of spinosad to control the two-spotted spider mite (Acari: Tetranychidae) on tomatoes grown in rockwool. Exp Appl Acarol 37:93-105. https://doi.org/10.1007/s10493-005-0139-8

Weintraub PG, Mujica N (2006). Note: systemic effects of Spinosad insecticide on Liriomyza huidobrensis larvae. Phytoparasitica 34:21-24. https://doi.org/10.1007/bf02981335 


\section{Chapter 4}

Williams T, Valle J, Viñuela E (2003) Is the naturally derived insecticide Spinosad® compatible with insect natural enemies? Biocontrol Sci Tech 13 (5):459-475. https://doi.org/10.1080/0958315031000140956

Witzgall P, Kirsch P, Cork A (2010) Sex pheromones and their impact on pest management. J Chem Ecol 36:80-100. https://doi.org/10.1007/s10886-009-9737-y

Wyckhuys KA, Heong KL, Sanchez-Bayo F, Bianchi FJ, Lundgren JG, Bentley JW (2019) Ecological illiteracy can deepen farmers' pesticide dependency. Environ Res Lett 14:093004. https://doi.org/10.7287/peerj.preprints.27579

Zhu P, Kong F, Yu S, Yu Y, Jin S, Hu X, Xu J (1987) Identification of the sex pheromone of eggplant borer Leucinodes orbonalis Guenee (Lepidoptera: Pyralidae). Z Naturforsch 42:1347-1348. https://doi.org/10.1515/znc-1987-11-1235 


\section{CHAPTER 5}

Smallholders and pheromone traps: when does an opportunity become a risk?

Naznin Nahar ${ }^{\mathrm{a}, \mathrm{b}}$, Mohammad Mahir Uddin ${ }^{\mathrm{a}}$, Peter de Jong ${ }^{\mathrm{b}}, \mathrm{Jacob}^{\mathrm{C}}$. Douma ${ }^{\mathrm{b}}$, Paul C. Struik ${ }^{\mathrm{b}}$, Tjeerd-Jan Stomph ${ }^{\mathrm{b}}$

${ }^{\text {a }}$ Faculty of Agriculture, Bangladesh Agricultural University, Mymensingh, 2202, Bangladesh

${ }^{\mathrm{b}}$ Department of Plant Sciences, Wageningen University \& Research, 6708 PB Wageningen, The Netherlands 


\title{
Chapter 5
}

\begin{abstract}
Mass trapping using pheromone traps could help control the eggplant shoot and fruit borer (ESFB) moth, a major pest constraining eggplant production in Bangladesh. In the smallholder context where lands are fragmented, it is unknown whether trapping on a single field basis would be effective and whether a minimum number of traps is needed to effectively deplete the local male moth population. Traps might attract a number of male moths from surroundings that could outweigh the local depletion and thus make the depletion ineffective. In the present study, we compared isolated fields with 4 traps or 24 traps (4× 6 traps) with a network of nearby fields with traps. The network comprised of three clusters having 22 , 28 and 40 traps respectively, spread over 3-5 fields per cluster and with 4-12 traps per field. Trap catch and fruit infestation (as an indicator of reproductive success) were monitored throughout the season. For infestation, farmers' conventional practice of controlling ESFB was used as a benchmark. On average across the season, moth catch per trap per week was three times higher in the 4-trap fields than in the 24-trap and network fields, the latter two showing similar catches. Reproductive success of moth was similar between 4-trap fields and farmers' practice fields without traps, indicating that local depletion in 4-trap fields was cancelled out by attraction from surroundings making the local mass trapping ineffective. In contrast, reproductive success of 24-trap and network fields was 19 to 22 percentage points lower than in farmers' practice fields; this indicates local depletion of male moths did outweigh attraction from surroundings. Depending on the exact landscape features and pest pressure, minimum trap densities should be established when advocating mass trapping in smallholders' fields. This study showed that trapping in individual fields of limited size (4-trap fields) was ineffective. However, a continuous trapped area (24-trap fields) or a network of nearby fields with traps were equally effective. It indicates, in smallholder context, concerted action will be required for effective trapping.
\end{abstract}

Keywords: Pheromone trap, Mass trapping, Smallholder farming, Concerted action 


\section{Introduction}

Pheromones are semiochemicals that contribute to pest management by modifying insect behaviour in a range of ways. Pheromones, particularly sex pheromones, interrupt insect reproduction by mating disruption through mass trapping and thereby provide pest control (Klein and Lacey, 1999; Witzgall et al., 2010). Pheromones act in small amounts and are species-specific, highly selective, and non-toxic to mammals or beneficial insects. Other than insecticides they therefore do not cause secondary pest outbreaks or pest resurgence. To alleviate the risks from pesticide use, pheromone-based pest management has become a valuable tool in integrated pest management (IPM) (Witzgall et al., 2010). For effective mass trapping, traps baited with synthetic sex pheromone are placed to remove a large proportion of male insects before mating with calling females. This reduces female reproductive success and thus provides long-term pest control (El-Sayed et al., 2006; Suckling et al., 2017). Control by mass trapping has shown considerable success for a wide range of insects, especially species of Lepidoptera, Coleoptera, and Diptera (El-Sayed et al., 2006; Witzgall et al., 2010).

For mass trapping to be effective, the density of traps should be high enough to effectively reduce the local male insect population (Riedl, 1980; Jamieson et al., 2008; Larrain et al., 2009). Moreover, it is crucial to determine whether traps should form a continuous grid or would be equally effective if placed in clusters of a few nearby fields. The position of traps in a particular arrangement will influence the numbers of males caught in those traps. When traps are arranged in small groups, the traps on corners are expected to catch more male insects than those in the centres because corner traps are likely to attract male insects from a larger area while they 'cover' the central traps from the immigrant moths (Fig. 1A). For the same reason plants in solitary plots with just a few traps or plants in plots that are at the corner of an area with many traps will likely be more heavily infested than plants in plots located in the centres of the area with many traps. These issues are especially relevant in developing countries where farming takes place on fragmented holdings of small fields.

Farmers of South Asian countries including Bangladesh are typically smallholders with fragmented farmland (Ahsan et al., 1989; Jha et al., 2005; Niroula and Thapa, 2005; Rahman and Rahman, 2009). This is also true for eggplant (Solanum melongena L.) farmers in Bangladesh, who cultivate generally plots of 400 to $600 \mathrm{~m}^{2}$. These farmers suffer from severe yield and economic losses due to infestation of the eggplant shoot and fruit borer moth (ESFB, Leucinodes orbonalis, Lepidoptera: Pyralidae) (Alam et al., 2006; Srinivasan, 2008). To combat this pest, farmers weekly spray broad spectrum pesticides alone or in cocktails 


\section{Chapter 5}

(Mohiuddin et al., 2009; Shelton et al., 2018). Such huge application of a range of insecticides has caused classic pesticide-use problems including insecticide resistance (Ruberson et al., 1998; Chowdhury et al., 2013; Miah et al., 2014). Moreover, pesticides are found ineffective and wasting farmers' money, while pheromone trapping in principle provides a good alternative for these farmers (Chapter 4).

Indeed, decades ago, a mass trapping treatment against ESFB was developed (Cork et al. 2001, 2003, 2005) and promoted in South and South-East Asia including Bangladesh (Alam et al., 2006). The Department of Agricultural Extension (DAE), Bangladesh, has picked up this method and incorporated pheromone trapping as one of the components of eggplant IPM in their farmer field school IPM curricula (Mukta et al., 2020). However, neither the IPM developer nor the extension material provides an indication how this mass trapping can best be implemented in small land holders' fields given the need for a sufficient trap density and proper trap arrangement to create a large enough depletion.

In our previous participatory ESFB management study with farmers (Chapter 4), we tested pheromone trapping alone and in combination with biorational insecticide applications by placing traps as a network across nearby fields of varying size. We found the trapping to be effective, safe to natural enemies and economically sound (Chapter 4). However, the study did not test whether trapping in a single field of a smallholder (individual farmer level) in a landscape where the same crops are widely grown would be able to sufficiently deplete the local male moth population to provide an effective control. In case of trapping in a single field surrounded by fields without traps, more moths from the surroundings might be attracted annihilating the effect of local depletion. In our previous study (Chapter 4), farmers considered that maintaining traps was easy and trapping was cost-effective compared with conventional spraying; but farmers also stated their fear that insects might be attracted from neighbouring fields if they are the only ones in the landscape that implement trapping.

In this study, we compared isolated fields with 4 traps (single field) or 24 traps $(4 \times 6$ traps: 3-4 adjacent fields) and a network comprising three clusters having 22, 28 and 40 traps, respectively, spread over 3-5 fields with 4-12 traps per field (Figs. 1 and 2). The between-field distance in the network was 10-25 m within clusters while the distance between nearest traps of two adjacent clusters was about $44 \mathrm{~m}$ or more. Male moth catches in the traps and fruit infestation from observation plots were assessed weekly, the latter representing reproductive success of the moths. We compared the infestation with observations in fields exposed to farmers' conventional practice. 
This study aims to contribute to insight into how pheromone trapping of ESFB can be made effective for smallholder eggplant growers. We hypothesize that if pheromone traps are installed at individual field level (4 traps), attraction of male moths from surroundings will outweigh local depletion and thus will make the trapping ineffective. When the trapped area will be increased either through a continuous trap setting (24 traps) or through a network setting of nearby fields, male moth depletion would be effective. We also hypothesize that when a larger area would be trapped with for instance 24 traps, reproductive success would be significantly reduced, and that plots in the centre of the trapped area would be significantly better protected than plots at the corners of the area or in the network. There is no good ground to hypothesize whether the corner plots of the area would be comparably or differently protected than plots in a network.

\section{Materials and methods}

\subsection{Study site}

The experiment was conducted in Pirijpur village $\left(25^{\circ} 02^{\prime} 13^{\prime \prime} \mathrm{N}-89^{\circ} 50^{\prime} 08^{\prime \prime} \mathrm{E}\right)$, Jamalpur district, the major eggplant growing area of Bangladesh, located in the so-called Old Brahmaputra floodplain. Farmers cultivate eggplants during the cool dry season (Rabi season: SeptemberMarch).

\subsection{Trap settings}

We tested three types of trap settings: a 4-traps setting (in a single small field) in seven replicates, a 24-traps setting (in 3-4 adjacent small fields) in five replicates, and a setting as a network of nearby small fields with traps (Figs. 1 and 2). Replicates of each trap setting and farmers' practice were allocated over the landscape depending on the availability of eggplant fields from farmers that were willing to contribute fields for this study. In the network setting, also used for Chapter 4 year 2, three clusters (considered replicates) could be distinguished that had respectively 22, 28 and 40 traps, spread over 3 to 5 fields with between 4 and 12 traps each and a between-field distance of 10-25 $\mathrm{m}$ within clusters, while the distance between nearest traps of two adjacent clusters was 44 and $50 \mathrm{~m}$ (Fig. 1C). For comparison of infestations without pheromone trapping, there were nine replicates of observation plots in farmers' practice fields. Distances between farmers' practice fields and fields of any trap setting and between replicates of the 24-trap fields and 4-trap fields were all kept at a minimum of $100 \mathrm{~m}$ to avoid interference. 


\section{Chapter 5}

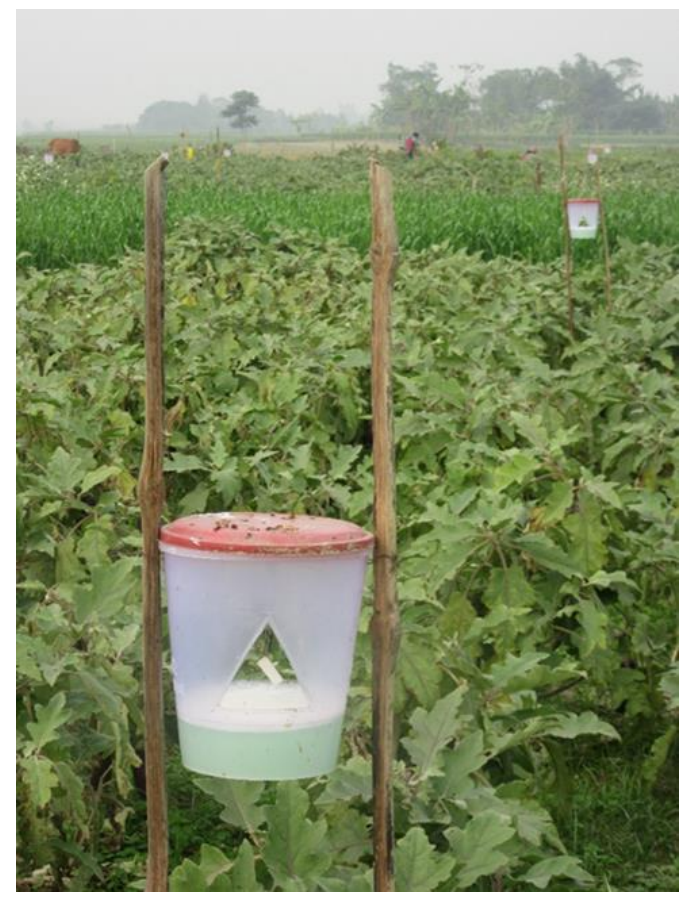

Photo 1. Pheromone trap arrangements in the landscape

In the network fields, the traps were installed at 30 days after transplanting (DAT) while traps in the 24- and 4-trap fields were installed 45 DAT due to a delay in field selection. Traps were installed in a $10 \mathrm{~m} \times 10 \mathrm{~m}$ grid keeping $5 \mathrm{~m}$ distance from all field borders. Water pan traps (Ispahani Biotech, Bangladesh) were mounted on bamboo poles and baited with lures consisting of a polyethylene vial impregnated with $3 \mathrm{mg}$ of a (97\% W/W) (E)-11-hexadecenyl acetate (E11-16:Ac) and (E)-11-hexadecen-1-ol (E11-16:OH) blends dissolved in $0.1 \mathrm{ml}$ hexane solution (Ispahani Biotech, Bangladesh) (Photo 1). Trap height was adjusted periodically according to plant growth to keep it $10 \mathrm{~cm}$ above the canopy. Lures were replaced every four weeks and water with detergent for effective insect drowning was changed weekly. In the 24-trap fields, traps were placed in 4 lines, each having 6 traps. According to this setting, there were 4 corner, 12 border and 8 centre traps (Fig. 1A). In the network fields, the 4-12 traps were always installed in two lines thus having a varying number of border traps only and no centre traps. In the 4-trap fields, all traps were in the corner. No spraying was done in pheromone trap treated fields; farmers were promised monetary compensation in case yield would be compromised. In farmer-managed plots, we observed that the insecticides Chlorpyrifos (48 EC), Cypermethrin (10 EC), Malathion (57 EC) alone or in cocktails were 
applied weekly at a concentration of each $1.5 \mathrm{ml} / \mathrm{L}$ of water $(760 \mathrm{ml} / \mathrm{ha})$ from $20 \mathrm{DAT}$ to the end of the season.

A.

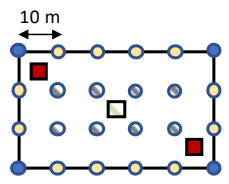

- Corner trap

- Border trap

O Centre trap
B.

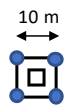

C.

Network setting

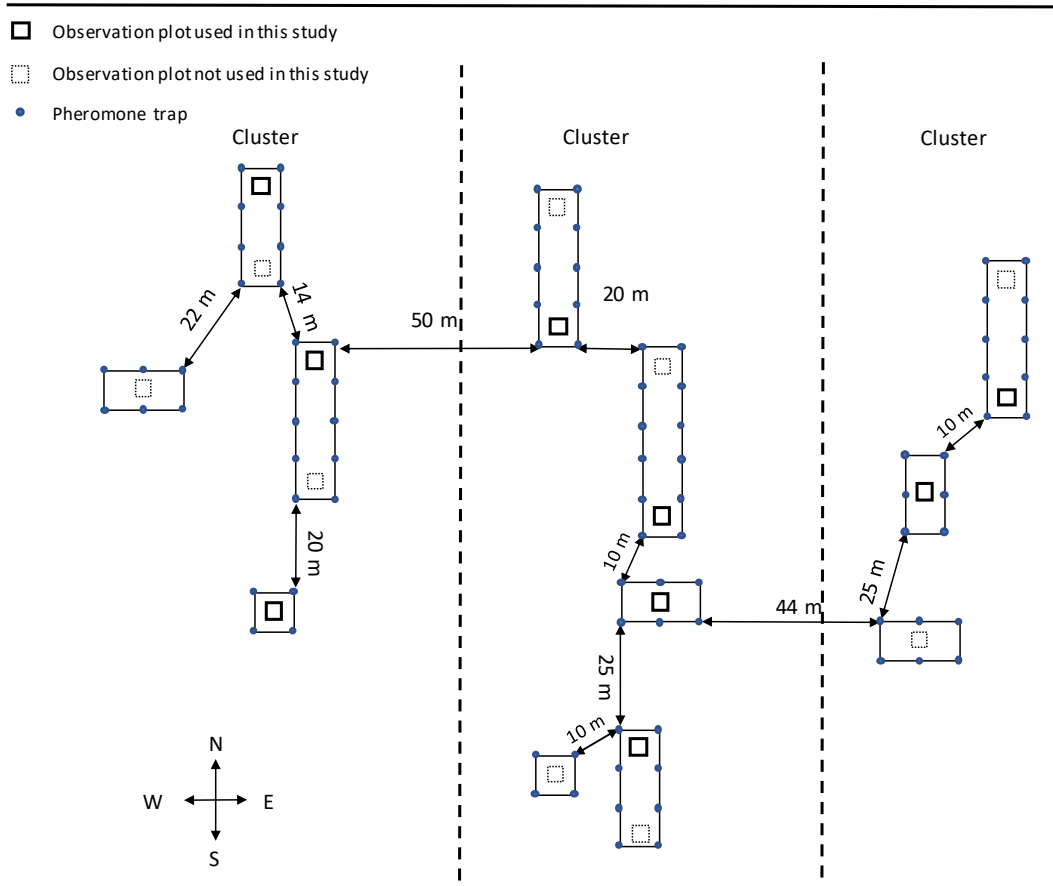

Fig. 1. (A) A typical 24-trap setting, with two observation plots in opposite corners and one in the centre; size of observation plots was $4 \mathrm{~m} \times 4 \mathrm{~m}$. (B) A 4-trap setting with observation plot. (C) The full network of fields with traps and the three distinguished clusters, each with 3-5 fields and per field 4-12 traps. Actual fields extended always at least $5 \mathrm{~m}$ on all sides beyond the indicated rectangle areas with traps. Observations plot indicated with dotted lines were not used in this study as pheromone trapping was accompanied by trap-catch-based spraying of biorational insecticide as additional insect control measure used in the study reported in Chapter 4. 


\section{Chapter 5}

\subsection{Observations}

Moths per trap were recorded weekly while replacing the water in the traps. When trapped moths were few, all moths were hand-picked directly by forceps, counted and discarded. When there were many moths, water from the trap was poured on muslin cloth, and moths were counted.

Eggplants were harvested weekly from $4 \mathrm{~m} \times 4 \mathrm{~m}$ observation plots (Fig. 1). To avoid influence of spraying in nearby fields, observation plots were placed in the centre of fields with a minimum of 5-8 $\mathrm{m}$ distance from borders of nearby fields for the network and 4-trap fields. In the 24-trap fields, eggplants were harvested from three observation plots: two diagonally placed corner plots and one plot from the centre (Fig. 1A). To avoid interference by pesticide applications, corner observation plots were at least $8 \mathrm{~m}$ away from the borders of any nearest field. Healthy and infested eggplants were weighed using a digital scale. Any fruits having holes, frass attached or a secondary infection (sign of rotting other than through Phomopsis rot, Chapter 3) were considered infested. The percent infested fruits per plot was both calculated per observation day and cumulative over the season; the latter was calculated based on cumulative weight $(\mathrm{kg})$ of infested and healthy fruits. Any plant loss in observation plots due to bacterial wilt was compensated by including plants directly surrounding the observation plot. Thereby, a total yield was obtained as if there were no wilt losses.

\subsection{Statistical analyses}

All statistical analyses were performed in R version 3.6.1. Data were tested for normality and homogeneity of variances using Shapiro-Wilkinson and Levene's tests. Yield data met all assumptions and were analysed using a standard analysis of variance with post-hoc mean separation using Tukey's HSD test $(\alpha=0.05)$. Moth count and fruit infestation data was not normally distributed and therefore models using Poisson, zero-inflated Poisson, negativebinomial for the moth count were compared. A beta distribution was used for fruit infestation. Based on Akaike's Information Criterion (AIC) moth counts were best analysed using a negative binomial distribution. For both data sets the best model included observation time, treatment and their interaction as fixed effect and field and trap number as random effect. Random effects were added to correct for possible correlations from observations coming from the same field or trap. 


\section{Results}

\subsection{Trap catch}

The interaction between time of observation and treatment was significant as catches for the different treatments varied over time $(\mathrm{P}<0.05)$. However, as a general trend, trap catches were highest in the 4-trap fields as was the seasonal average catch per week (Figs 2A, 3A). Sometimes catches in the 4-trap fields were not significantly higher than what was found in the corner traps of the 24-trap fields ( 8 of 21 observations) or the network ( 3 of the 21 observations). Averaged over the season, though, the catches in 4-trap fields (44.8 moths per trap per week) were roughly twice that in corner traps of the 24-trap fields (24.3 moths per trap per week) and three time that in network traps (14.8 moths per trap per week). The catches in the centre traps of the 24-trap field were generally lowest and on average (8.2 moths per trap per week) roughly half that in network and border traps (14.8 and 16.5 respectively), although in 7 of the 21 observations, catches were not significantly different from network traps and in 4 of the 21 observations not significantly lower than in the border traps of the 24-trap fields. Network traps and corner and border traps of the 24-trap field were not systematically catching different numbers of moths, although on half of the observation days catches were found to differ significantly. When significantly different corner traps always had higher catches, while network traps and border traps took turns in having the next higher catches (Fig. 3A).

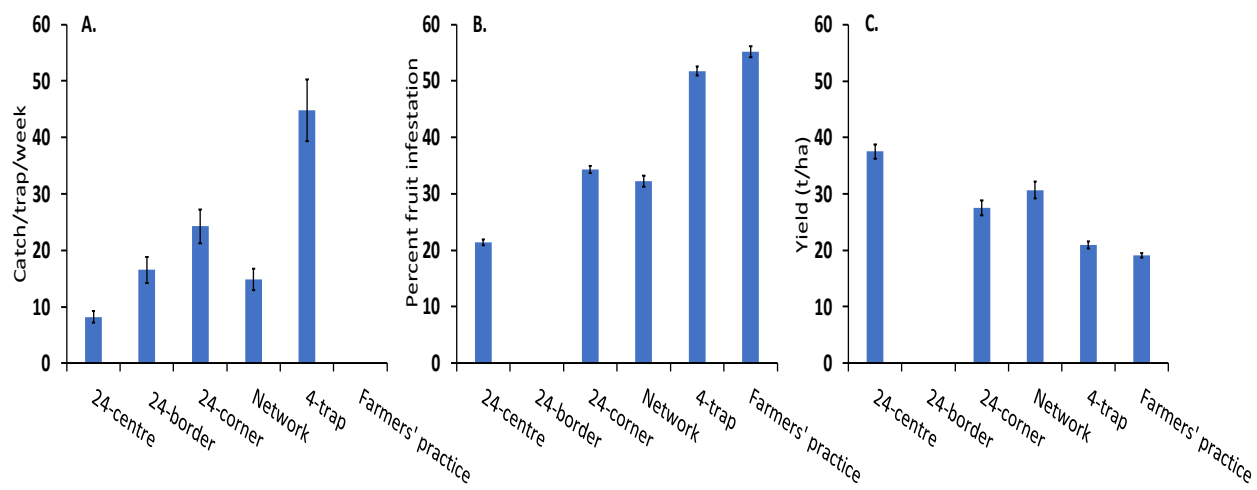

Fig. 2. (A) Seasonal average of number of eggplant shoot and fruit borer (ESFB) male moths caught per trap per week, (B) Percent cumulative fruit infestation by ESFB caterpillars, (C) Estimated yield of eggplants under different trap settings and farmers' practice, assuming no plant loss to bacterial wilt (for further details see text). In pane A data for farmers' practice plots are absent as no traps were installed there, in panes $\mathrm{B}$ and $\mathrm{C}$ data for 24-border are absent as no observation plots were installed there. Error bars represent standard errors of the mean. 


\section{Chapter 5}
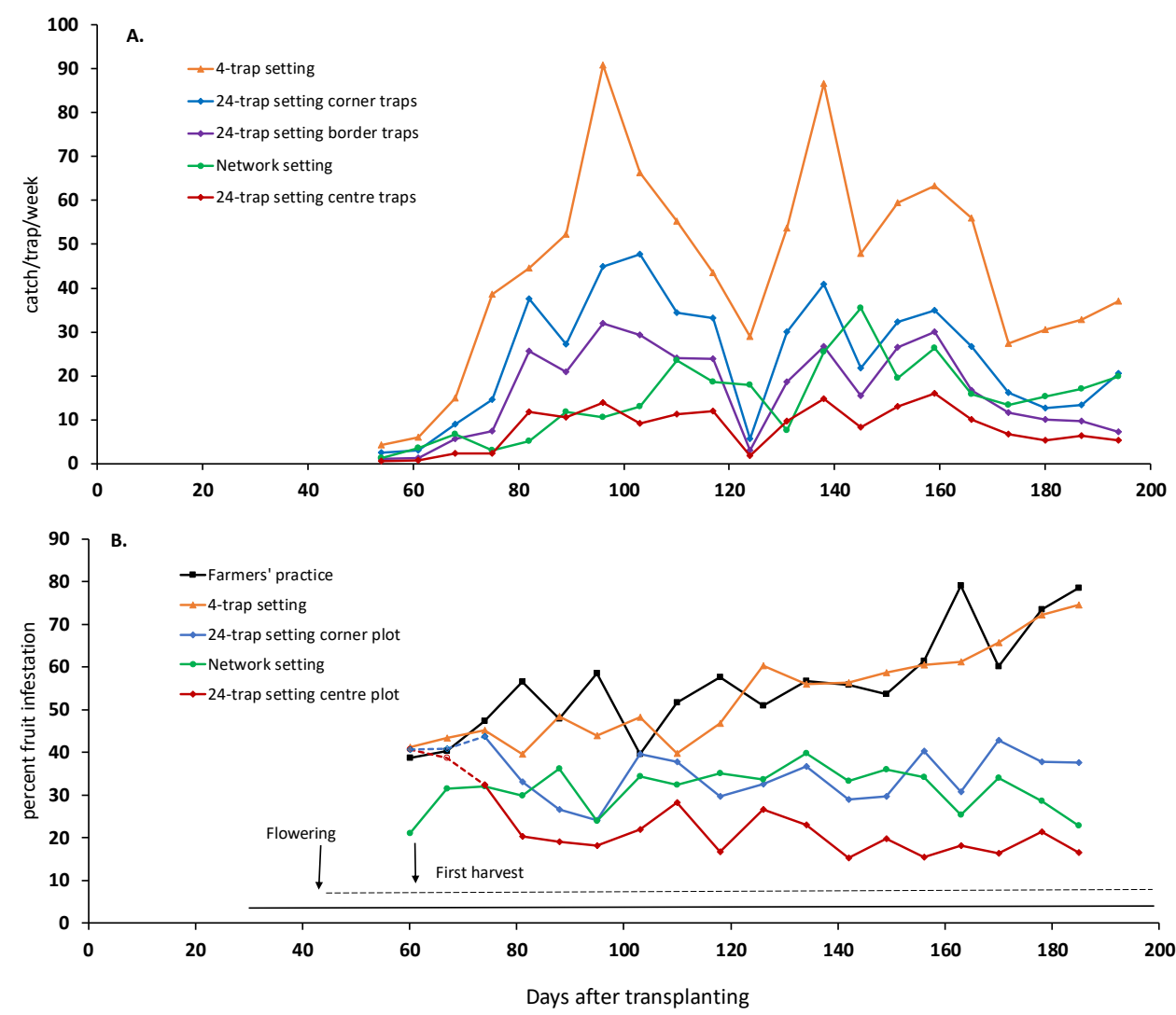

Fig. 3. (A) Weekly ESFB male moth catch over time under different trap settings; there were no traps in farmers' practice fields. (B) Percent fruit infestation over time under different trap settings and in farmers' practice fields. The broken coloured lines and open symbols for infestation observed in 4-trap and 24-trap fields indicate data obtained before effects could be expected based on late placement of traps (see text). The two horizontal lines at the bottom of pane B indicate for both panes duration of pheromone trapping in network fields (solid black line) and in 4-trap and 24-trap fields (the broken lines).

\subsection{Fruit infestation}

The observations 60 and 67 days after transplanting were excluded from analysis because of difference in trap installation time between networks and other trap settings (see Materials and Methods). The interaction between time of observation and treatment was significant as infestation for the different treatments varied over time $(\mathrm{P}<0.05)$. At most dates across the season, infestation of farmers' practice fields and 4-trap fields was similar $(\mathrm{P}>0.05)$ as were seasonal averages with 55\% and 52\% respectively (Figs. 2B and 3B). Only on 5 out of 16 observation dates was infestation of fruits on 4-trap fields different from infestation on farmers' 
practice fields. Infestation of centre plots of 24-trap fields were always lower than corner plots of the same trap setting and network fields; only on 4 observation dates at the beginning of the harvest period was infestation between corner and centre plots similar. Network fields showed lower infestation than 24-centre plots at the beginning of harvest period because traps in the network fields were installed 15 days earlier than 24-trap fields; however, from 118 days onwards centre plots gradually showed lower infestation than network fields. As a consequence, the seasonal average for the centre of the 24-trap fields showed substantially lower infestation (11-13 percentage points) than observation plots in the corner of the 24-trap fields and network fields and all three had significantly lower infestation than plots exposed to farmers' practice (Fig. 2B). Corner plots of 24-trap fields and network fields showed a same infestation throughout the season except at the beginning of the harvest period when infestation in network fields was lower due to time difference in trap installation dates between these fields (Fig. 3B).

\subsection{Yield}

Significantly higher fruit yields were obtained from centre and corner plots of the 24-trap fields and from plots in network fields than in plots of the 4-trap fields and farmers' practice fields. Farmers' practice and 4-trap field plots produced similar yields (19-20 t/ha), while an extra 7$10 \mathrm{t} /$ ha was obtained in the corner plots of the 24-trap fields and plots in the network fields; finally, centre plots of the 24-trap fields yielded yet another 7-10 t/ha more so almost double the yields of plots in farmers' practice fields (Fig. 2C). These yields are total yields excluding reductions caused by bacterial wilt. Actual average wilt infestation across all fields reached $24 \%$, so actual marketable yields were roughly $24 \%$ lower across all treatments.

\section{Discussion}

The aim of the study was to observe whether trapping in a small field (4-trap setting) surrounded by fields without traps but with the same crop would lead to such attraction of male moths from surroundings that it would outweigh local depletion and make the depletion ineffective. And whether increasing the trapped area in size to $50 \mathrm{~m} \times 30 \mathrm{~m}$ with 24 traps, or when a comparable larger number of traps would be dispersed over nearby fields in a network setting, depletion would outweigh attraction from surroundings as shown by reduced fruit infestation and could thus provide effective control. We further hypothesized that when a more continuous area would be trapped (the 24-trap fields) infestation (reproductive success) would also be significantly more reduced in the centre of the trapped area than in plots at the corners of the 


\section{Chapter 5}

area and the network. We further posed the question whether corner plots in these 24-trap fields would have the same or a different protection compared to the plots in the network setting.

Putting traps in a single small field (4-trap setting) was found to be ineffective because it showed similar infestation with farmers' conventional practice fields without trapping. Despite catching three times more moths per trap per week than 24-trap and network fields, 4-trap fields showed 17-30 percentage points higher fruit infestation than aforesaid two trap settings (Fig. 2A, B). This finding suggests that attraction from surroundings outweighed the depletion in the 4-trap setting. When the trap number and trapping area was increased beyond that of the 4-trap setting to that of the 24-trap fields or the network of nearby fields, effective depletion was achieved (i.e. depletion could outweigh the attraction from surroundings) as evidenced by the lower fruit infestation than in 4-trap fields and farmers' practice fields. Again, in 24-trap fields, trap catch and reproductive success (as evidenced by infestation) in the centre plot was lower than that of corner plots and infestation in corner plots was comparable with infestation in the network fields. It suggests if trapping is done in a continuous grid over a larger area, plots in the central part of that area will be more protected and plots in corner areas will have the same protection as the fields in the more dispersed sets of traps in our network setting of traps (Fig. 1). These findings have important practical implications for the introduction of mass trapping in the context of smallholder farming communities.

\subsection{Possible reasons for differences in efficacy of mass trapping in 4-trap and 24-trap and network fields}

Mass trapping aims at locally depleting male populations to such an extent that it impairs the mating success and thus reduces infestation (El-Sayed et al., 2006). On average across the season, traps from 4-trap fields attracted around thrice as many male moths per trap as traps in the 24-trap or network setting fields (Figs. 2A and 3A). Despite the observed mass trapping in the 4-trap fields of around 45 moths per trap per week (Fig. 2A), fruit infestation was similar to plots where no traps were placed (farmers' practice fields) and substantially higher than in the observation plots in 24-trap and network fields. Moreover, despite weekly spraying farmers' practice does not control the ESFB as infestation was comparable to untreated control plots (Chapter 4). The lower numbers of trapped male moths in the 24-trap fields (15 moths per trap per week) were accompanied by lower infestation in both corner and centre observation plots (Fig. 2B). Assuming that the percent infestation reflects reproductive success, it demonstrates that female reproductive success was compromised by the mass trapping of male moths in the 24-trap fields but not in the 4-trap fields. Assuming that the female population spread and egg 
deposition are not influenced by the pheromone traps, females are equally available across the landscape to mate with any males that are not (or not yet) caught, whether such males emerged locally or were attracted from the surrounding area by the luring substances. In normal conditions, females find sufficient males to mate and will then find eggplants to lay all their eggs. Male moths may become the limiting factor of the reproductive success of females if the male population is sufficiently depleted locally. The current study indicates that just 4 traps surrounding a plot in a landscape with a lot of eggplant fields will not allow sufficient depletion to hamper reproductive success. A larger trap density is needed.

In 24-trap fields, averaged across the season, traps that were in the centre of the field caught the lowest number of moths per week per trap and the corresponding reproductive success was also lowest in the central observation plots which were surrounded by eight centre, twelve border and four corner traps (Fig. 1A). This finding makes it plausible that attraction from surroundings played a much smaller role in these plots, and mainly locally emerged males escaping control might have allowed reproduction. Despite this substantial impairment of the reproductive success of females full control was not reached. Such full control has also not been reported in other successful cases of pheromone trap use; Cork et al. (2005) e.g. reported a remaining $18 \%$ infestation. However, reproductive success was reduced by 34 percentage points compared with farmers' control, making it an effective strategy. Compared with the centre plots, the corner plots of the 24-trap fields showed higher fruit infestation (13 percentage points higher; Fig. 2B). Due to its location in the corner, attraction from surroundings probably partially compensated the local male population depletion. Despite this attraction from surroundings, depletion in corner plots was more effective than in 4-trap fields as indicated by the 17 percentage points lower reproductive success and roughly half the number of male moths caught per trap per week. One of the reasons for this higher effectiveness might be that the male moths attracted by the lures in the 24-trap setting were spread over more traps and a larger area. So, dilution of attracted moths is larger when more traps are situated close-by. A similar type of catch difference between corner and centre traps was reported in other studies for Lepidopteran insects (Mafra-Neto and Habib, 1996; Suckling et. al., 2017). Lower infestation in network fields might also be linked to the fact that moths were diluted in the larger area.

Infestation was equally reduced in the corner plots of 24-trap fields and network fields and infestation in centre plots was either comparable or lower than both, the latter especially towards the end of the season (Fig. 3B). Also trap catches averaged across the season were similar for traps in network fields and traps in 24-trap fields, although on most dates lower 


\section{Chapter 5}

catches were observed in the centre traps of the 24-trap fields. This means the network setting led to sufficient depletion of the male moth population that emerged locally and that was plausibly attracted from surrounding areas to have a net reduction of reproductive success. Although fields in the network sometimes had four traps like the individual plots in the 4-trap fields (Fig. 1C), adjacent plots in the network were located sufficiently close-by to dilute the moths attracted from the surroundings.

\subsection{Population build-up and infestation over time}

In the 4-trap fields, due to attraction from surroundings, the male moth population remained higher throughout the season particularly from 75 DAT onwards compared with the 24-trap and network fields (Fig. 3A). Thereby reproductive success in the 4-trap fields gradually increased (Fig. 3B), as shown by increasing fruit infestation. Especially from 126 DAT to the end of the season it drastically rose as was observed in farmers' practice fields (Fig. 3B). The completion of the life cycle of ESFB has been reported to take 25-40 days (Srinivasan, 2008; Mannan et al., 2015). The first moths were observed around 30 DAT. After roughly three generations (100126 DAT), the infestation went up gradually in the 4-trap fields and under farmers' practice (Fig. 3B). In the corner and centre plots of the 24-trap fields and in the network fields, infestation was stable throughout the season and lower than in farmers' practice fields at most time points throughout the season. However, only from half-way the season onwards a substantial reduction of infestation became apparent as populations did not get out of hand as on farmers' practice fields (Fig. 3B).

The infestation data at the start of the season clearly show that there is a time lag of roughly one generation between installing traps and reduction of infestation. In network fields, the traps were installed 30 DAT, while traps in the 4-trap and 24-trap fields were installed 45 DAT. Infestation in the network fields was lower than in farmers' practice fields at first harvest 60 DAT (Fig. 3B), while infestation in the 24-trap fields dropped below that of farmers' practice plots only from day 74 onwards, so roughly one generation time (Srinivasan, 2008; Mannan et al., 2015) after traps were installed. So, it takes time before trapping leads to effective population reduction. We conclude: i) starting trapping early is essential for farmers, also as early in the season prices of eggplants tend to be highest; ii) farmers have to wait quite a long time to see substantial reduction of infestation compared with their current practice which was earlier shown to be as good as doing nothing (Chapter 4); iii) farmers need to understand that there is a 20-30 day time difference between peaks in catches and peaks in infestation. The latter two aspects are important complications to scale out trapping among farmers. Our data 
also tell how difficult it is to make farmers understand the efficacy of mass trapping because at the beginning of the season the effects are limited as shown by the small differences compared with farmers' practice.

\subsection{Management implications}

Our study was conducted in a typical eggplant growing village of Bangladesh where $80 \%$ of total cultivable land is occupied by eggplant (personal observation) and where infestation by ESFB is around $50 \%$ (Chapter 4$)$. Therefore, the question was how suitable pheromone trapping is when the average field of a single smallholder allows to install just four traps. Based on trap catches, infestation and yield, results from the present study indicate that such trapping indeed would not be profitable and in fact economically risky, supporting the farmers who stated "if we put traps alone then we might attract more insects" (Chapter 4).

Both when 24-traps are placed as a continuous array of $4 \times 6$ traps and when traps are placed in a network setting where 22-40 traps were placed in three clusters, the infestation is reduced and yield increased to a level that outperformed current farmers' practice. Hence, both types of trapping are a strategy for farmers to adopt. Given current plot sizes and prevalence of eggplant cultivation in the study area, farmers of nearby fields should organise themselves. Although an exact minimum number traps cannot be established from the current data, we suggest farmers to either create a network of at least 22 traps on nearby fields covering roughly 0.4 ha as in our network or organise themselves as direct neighbours to form a continuous $10 \mathrm{~m}$ x $10 \mathrm{~m}$ grid of 24 or more traps. In our previous study over two years on ESFB management, trapping in the network was cost-effective (Chapter 4), therefore, trapping by installing a continuous array of 24 traps would also be cost-effective. Installing 24 traps would require 3-4 farmers to organise themselves while sharing the costs and labour. The better control observed in the centre plots of the 24-trap fields indicates that more dense networks or larger fields will likely be more effective as the central area would become larger. Whether the centre of a larger field would be showing yet lower infestation than the centre of the 24-trap fields cannot be concluded without further research. The observation that farmers with central plots will benefit more than those who are in the corners may potentially become a source of dispute. Such differences we have not seen between the plots in the networks, but there were also no real central plots (Fig. 1C), likely leading to less chances for debate. 


\section{Chapter 5}

\section{Concluding remarks}

The study showed that mass trapping of ESFB in eggplant cropping is ineffective for an individual smallholder farmer, given the typical land holding size and fragmentation in Bangladesh. We showed that when the trapping area was larger (continuous $10 \mathrm{~m} \times 10 \mathrm{~m}$ grid of 24 traps), local depletion of the population of male moths became larger than any attraction from surrounding areas giving an effective control. Thereby, concerted action of smallholder farmers is needed to make mass trapping successful. We conclude that a continuous array of 24 traps or a network of nearby small fields with in total 22 or more traps and a minimum trap density on 1 trap per $200 \mathrm{~m}^{2}$ were both effective arrangements. Further research could establish more exactly the minimum network size and trap density to suppress moth populations. Given the importance of the role of attraction in annihilating the targeted local depletion in mass trapping, establishing the exact attraction range of trap settings in landscapes that vary in moth density is needed to refine advice on minimum trap density. Whether individual trapping is effective in eggplant cultivation area with fewer and more widely spread eggplant fields might also be an interesting study.

In the present study, we have fine-tuned the method of trap placement for mass trapping by smallholders. Extension services and research organisations should consider these findings when recommending pheromone trap-based insect management to smallholders. Our findings are useful not only for Bangladesh but also for other countries of South Asia where the same pest is major and vegetable farmers are by and large smallholders. We are the first to disentangle that pheromone trapping despite massive trapping of target males does not necessarily lead to effective mass trapping and that such effective trapping means not only placing pheromone traps but also organising (neighbour) farmers.

\section{Acknowledgements}

We acknowledge NUFFIC (The Dutch Organisation for Internationalization in Education), The Netherlands, for funding the research under their NICHE programme (grant number NUFFICNICHE-BGD-156), a collaboration between Wageningen University and Research (WUR) and Bangladesh Agricultural University (BAU). We acknowledge participating farmers of Pirijpur for allocating land for this study. We further acknowledge the farmer trainers for assistance in the study and the villagers for co-operation and support. 


\section{References}

Ahsan, E., Ahsan, R. M., Hussain, S. H., Kemper, R. V. and Wallace, B. J., 1989. Ownership and Control: Land Acquisition, Fragmentation, and Consolidation in Rural Bangladesh. Urban Anthropology and Studies of Cultural Systems and World Economic Development, pp. 299327.

Alam, S. N., Hossain, M. I., Rouf, F. M. A., Jhala, R. C., Patel, M. G., Rath, L. K., Sengupta, A., Baral, K., Shylesha, A. N., Satpathy, S., Shivalingaswamy, T. M., Cork, A., Talekar, N. S. 2006. Implementation and promotion of an IPM strategy for control of eggplant fruit and shoot borer in South Asia. Technical Bulletin No. 36. AVRDC publication number 06-672. AVRDC - The World Vegetable Center, Shanhua, Taiwan.

Chowdhury, M. A., Fakhruddin, A. N., Islam, M. N., Moniruzzaman, M., Gan, S. H., Alam, M. K., 2013. Detection of the residues of nineteen pesticides in fresh vegetable samples using gas chromatography-mass spectrometry. Food Control, 34: 457-465.

Cork, A., Alam, S. N., Das, A., Das, C. S., Ghosh, G. C., Farman, D. I., Hall, D. R., Maslen, N. R., Vedham, K., Phythian, S. J., Rouf, F. M. A., 2001. Female sex pheromone of brinjal fruit and shoot borer, Leucinodes orbonalis blend optimization. Journal of Chemical Ecology, 27: 18671877 .

Cork, A., Alam, S. N., Rouf, F. M. A., Talekar, N. S., 2003. Female sex pheromone of Brinjal fruit and shoot borer, Leucinodes orbonalis: Trap optimization and application in IPM trials. Bulletin of Entomological Research, 93: 107-113.

Cork, A., Alam, S. N., Rouf, F. M. A., Talekar, N. S., 2005. Development of mass trapping technique for control of brinjal shoot and fruit borer, Leucinodes orbonalis (Lepidoptera: Pyralidae). Bulletin of Entomological Research, 95: 589-596.

El-Sayed, A. M., Suckling, D. M., Wearing, C. H., Byers, J. A., 2006. Potential of mass trapping for long-term pest management and eradication of invasive species. Journal of Economic Entomology, 99: 1550-1564.

Jamieson, L. E., Suckling, D. M., Ramankutty, P., 2008. Mass trapping of Prays nephelomima (Lepidoptera: Yponomeutidae) in Citrus orchards: optimizing trap design and density. Journal of Economic Entomology, 101: 1295-1301.

Jha, R., Nagarajan, H. K., Prasanna, S., 2005. Land fragmentation and its implications for productivity: Evidence from Southern India. ASARC working paper.

Klein, M. G. and Lacey, L. A., 1999. An attractant trap for autodissemination of entomopathogenic fungi into populations of the Japanese beetle Popillia japonica (Coleoptera: Scarabaeidae). Biocontrol Science and Technology, 9: 151-158.

Larraín, S. P., Guillon, M., Kalazich, J., Graña, F.,Vásquez, C., 2009. Effect of pheromone trap density on mass trapping of male potato tuber moth Phthorimaea operculella (Zeller) (Lepidoptera: Gelechiidae), and level of damage on potato tubers. Chilean Journal of Agricultural Research, 69: 281-285. 


\section{Chapter 5}

Mafra-Neto, A. and Habib, M., 1996. Evidence that mass trapping suppresses pink bollworm populations in cotton fields. Entomologia Experimentalis et Applicata, 81: 315-323.

Mannan, M. A., Islam, K. S., Jahan, M., Tarannum, N., 2015. Some biological parameters of brinjal shoot and fruit borer, Leucinodes orbonalis Guenée (Lepidoptera: Pyralidae) on potato in laboratory condition. Bangladesh Journal of Agricultural Research, 40: 381-390.

Miah, S. J., Hoque, A., Paul, A., Rahman, A., 2014. Unsafe use of pesticide and its impact on health of farmers: A case study in Burichong Upazila, Bangladesh. Journal of Environmental Science, Toxicology and Food Technology, 8: 57-67.

Mohiuddin, M., Hossain, M. M., Rahman, A. K., Palash, M. S., 2009. Socio-economic study of insecticide use on vegetable cultivation at farm level in Chittagong region. Journal of Bangladesh Agricultural University, 7: 343-350.

Shelton, A. M., Hossain, M. J., Paranjape, V., Azad, A. K., Rahman, M. L., Khan, A. S. M. M. R., Prodhan, M. Z. H., Rashid, M. A., Majumder, R., Hossain, M. A., Hssain, S. S., Huesing, J. E., McCandless, L., 2018. Bt eggplant project in Bangladesh: history, present status, and future direction. Frontiers in Bioengineering and Biotechnology, 6:106.

Mukta, M. Z. N, 2020. Understanding interactions and relationships in pest management innovation processes in Bangladesh. Doctoral dissertation, Wageningen University, Wageningen, the Netherlands.

Niroula, G. S. and Thapa, G. B., 2005. Impacts and causes of land fragmentation, and lessons learned from land consolidation in South Asia. Land Use Policy, 22: 358-372.

Rahman, S. and Rahman, M., 2009. Impact of land fragmentation and resource ownership on productivity and efficiency: The case of rice producers in Bangladesh. Land Use Policy, 26: 95103.

Riedl, H., 1980. The importance of pheromone trap density and trap maintenance for the development of standardized monitoring procedures for the codling moth (Lepidoptera: Tortricidae). The Canadian Entomologist, 112: 655-663.

Ruberson, J., Nemoto, H., Hirose, Y.,1998. Pesticides and Conservation of Natural Enemies in Pest Management. In: Barbosa, P. (Eds), Conservation Biological Control. Academic Press, pp. 207 220 .

Srinivasan R., 2008. Integrated pest management for eggplant fruit and shoot borer (Leucinodes orbonalis) in south and Southeast Asia: past, present and future. Journal of Biopesticide, 1:105112 (2008).

Suckling, D. M., Stringer, L. D., Kean, J. M., Lo, P. L., Bell, V., Walker, J. T., Twidle, A. M., JiménezPérez, A., El-Sayed, A. M., 2017. Spatial analysis of mass trapping: how close is close enough? Pest Management Science, 71: 1452-1461.

Witzgall, P., Kirsch, P., Cork, A., 2010. Sex pheromones and their impact on pest management. Journal of Chemical Ecology, 36: 80-100. 
CHAPTER 6

General Discussion 


\section{Chapter 6}

The research described in this thesis was inspired by the poor adoption rate of integrated pest management (IPM) in developing countries. Despite huge investment in IPM research and its substantial promotion, IPM has a low adoption rate, particularly in developing countries (Morse and Buhler, 1997; Parsa et al., 2014; Bottrell and Schoenly, 2018; Alwang et al., 2019). Reasons identified include weaknesses in research, poor outreach, poor quality of the proposed IPM and poor farmer training and organisation (Parsa et al., 2014). When developing solutions, more attention was given to technical excellence of IPM than to practical implementation (Morse and Buhler, 1997). The core of this thesis is to understand why IPM is so difficult to implement for smallholder farmers in developing countries and what is needed to make IPM workable for them. To contribute to this understanding, eggplant production in Bangladesh was taken as a case because eggplant farmers poorly adopted a previously recommended IPM for the control of the eggplant shoot and fruit borer (ESFB); their main pest control strategy is frequent (weekly) spraying. The main objective of this thesis was to craft together with farmers IPM options that could function in their context, that maximally use natural enemies and that significantly reduce pesticide use. Alongside, this thesis assessed the possible reasons for IPM research failures and possible factors contributing to the success of and bottlenecks to adoption of the crafted IPM. A major contribution of this thesis thus lies not only in providing IPM options that are suitable for farmers but also providing insights on how IPM can be made more adoptable for smallholder farmers.

The general introduction chapter of this thesis culminated into the following four research objectives:

(i) to investigating a feasible disease management option for farmers' nursery problems with damping-off (Chapter 2);

(ii) To investigate the causes of the bacterial wilt and fruit rot and their management options (Chapter 3);

(iii) to explore the effectiveness, profitability and practicability of alternative eggplant shoot and fruit borer (EFSB) control measures to the sole reliance on broad spectrum synthetic pesticides (Chapter 4);

(iv) to explore suitability of pheromone trapping for individual smallholder farmers versus trapping with a network of farmers (Chapter 5). 
Through a number of participatory studies conducted with eggplant farmers, I attempted to provide IPM options for both disease and insect problems: damping-off in the nursery, bacterial wilt and fungal fruit rot in the production field and damage from caterpillars of the eggplant shoot and fruit borer moth in the production field. I have also used the negotiations and discussions with these farmers to get a better grip on the underlying complexity of all tested IPM options that might hamper adoption. Besides the participatory study with farmers, I conducted a few in vitro and screen house studies to identify the source of infection of the diseases and to disentangle relative roles of selected IPM components in reducing infections. My research provided technically sound and economically viable IPM options for farmers for each of the disease and insect problems farmers had indicated to be their major concern. However, bottlenecks to scale out each of these IPM options still remain.

In this General Discussion, I integrate the results from the four research chapters, evaluate them in the light of the original objectives of the thesis, and discuss the insights and recommendations that appear from my findings. I discuss what basket of options my research has generated for farmers, what the bottlenecks were to implement those options and how these bottlenecks can be alleviated. I also reflect on the research approach of this thesis and discuss how this approach helped me to assess whether the identified IPM options are practicable or not feasible for farmers. Finally, I provide suggestions on what needs to be considered while developing IPM for smallholder farmers in developing countries. I conclude this chapter with my personal reflections and some concluding remarks.

\section{General findings from the research}

Damping-off is a major nursery problem of eggplant farmers that constrains production of sufficient healthy seedlings to transplant. Farmers spray their homestead nurseries to control damping-off with a range of products whose action is questionable based on active ingredients. Together with farmers I analysed effects and suitability of IPM strategies by combining available alternative control methods under farmers' conditions (Chapter 2). Soil application of Trichoderma harzianum (T. harzianum) combined with seed treatment with hot water reduced damping-off losses, increased seedling emergence and produced more healthy seedlings than farmers' conventional practice. This combined treatment also improved seedling performance (height, root length, lateral root development), and reduced stem girdling, a symptom associated with disease infection of transplants and with poor seedling vigour after transplanting. A seed treatment with Carbendazim suggested by farmers did not have any additional effect when $T$. 


\section{Chapter 6}

harzianum was applied in the soil. Soil proved to be the major pathogen source and treating nursery soil with $T$. harzianum had the largest positive effect on seedling survival and quality, both reducing damping-off and enhancing seedling growth.

Next to this nursery disease, bacterial wilt (Ralstonia solanacearum) and fruit rot (Phomopsis vexans) are two major diseases in the production field that constrain eggplant production of smallholders. Farmers spray to control these diseases. As an alternative, I tested a farmer-targeted integrated management option together with farmers (Chapter 3). Seedlings raised by conventional practices or following improved nursery management (nursery soil treated with $T$. harzianum and seed treated either with hot water or Carbendazim) were transplanted in farmers' fields either with or without soil application of T. harzianum. Using seedlings from improved nursery management tested in Chapter 2 reduced both diseases and increased yield and income compared with farmers' conventional practice. A comparable result was obtained when treating only the field with T. harzianum but not the nursery. Disease occurrence was further reduced when seedlings from improved nursery practices were transplanted in a field amended with $T$. harzianum. The costs of the introduced technology were lower than the costs of current farmers' practices, in terms of both labour and purchased materials. Soil and seeds both proved to be sources of pathogens. In vitro testing showed that T. harzianum persisted in the field soil until the end of the growing season and significantly reduced the population of both $R$. solanacearum and $P$. vexans in the soil and on the seeds collected from the eggplants. The reduction of pathogens both in the field soil and on the preserved seed from improved management plots may imply that a next crop will start with a lower level of disease pressure. This remains an aspect for further research.

The ESFB moth is another reason for the low eggplant production in Bangladesh. Caterpillars of this moth live and feed inside the fruit making them unfit for sale and consumption. Farmers massively spray insecticides to control the ESFB moths resulting in severe health and environmental problems. In a participatory study with farmers, I tested pheromone trapping alone or with conventional insecticide spraying or with a trap-based regime of biorational insecticide spraying (Chapter 4). Compared with current farmers' practice, pheromone trapping alone reduced fruit infestation and increased marketable yield and income. Moreover, it did not affect the abundance of natural enemies of other potential pest insects. Combining pheromone trapping with biorational spraying further reduced fruit infestation, and increased yield and income, and also did not affect natural enemies. However, combining pheromone trapping with conventional spraying did not provide further control compared with 
trapping alone, while reducing natural enemies. Farmers' conventional practice neither reduced infestation nor increased yield compared with no treatment at all, but it drastically reduced the abundance of natural enemies. Aphid and jassid populations, both potential problem insects, were reduced only by biorational and conventional spraying. In terms of economic feasibility, pheromone trapping alone required less labour and cash input than farmers' practice. Adding biorational insecticide slightly increased costs compared with farmers' practice but increased income more. Discussion with farmers revealed that farmers have difficulty in understanding the ESFB biology and the mechanisms behind pheromone trapping.

Eggplant farmers in Bangladesh are smallholders with fragmented lands. Putting traps only in an individual field in a landscape where eggplant is the major crop might not be effective: traps might attract so many male moths from the surroundings that it could outweigh the local depletion and thus make the depletion ineffective. I tested (using farmers' fields but under researcher control, so not with farmers' participation) three types of trap settings: isolated fields with 4 traps, isolated fields with 24 traps $(4 \times 6$ traps $)$ and a network of fields with traps (Chapter 5). The network comprised of three clusters having 22, 28 and 40 traps respectively, spread over 3-5 fields per cluster and with 4-12 traps per field (Chapter 5, Fig. 1). Averaged across the season, moth capture per trap per week was three times higher in the 4-trap fields than in 24-trap and network fields; the latter two showed comparable catches. Reproductive success of the moth, as indicated by fruit infestation, was similar for fields with 4-traps and farmers' practice fields without traps indicating that local depletion was cancelled out by additional attraction from surroundings making the trapping ineffective. Thus, putting traps in a typical individual field proved inefficient. In contrast, local depletion of male moths did outweigh attraction in 24-trap and network fields as reproductive success (infestation) was significantly lower than in farmers' practice fields. Depending on the exact landscape features and pest pressure, minimum trap densities should be established when advocating mass trapping in smallholders' fields. I found that a continuous trapped area (24-trap fields) or a network of nearby fields with traps might be equally effective.

Combining the findings of the four chapters, I will discuss below the basket of options of farmers to manage pests and diseases. 


\section{Chapter 6}

\section{Basket of options for farmers}

All the IPM options for either disease or insect control proved to be more technically effective and economically sound for farmers than their current practice of spraying (Chapters 2, 3, and 4). Thereby, the research reported in this thesis provides an array of options that can be advocated to farmers:

i) soil amendment to homestead nurseries with T. harzianum alone or combined with hot water treatment of seeds can control damping-off;

ii) transplanting improved nursery seedlings alone or with field soil amendment of $T$. harzianum can control bacterial wilt and fruit rot;

iii) pheromone trapping alone or combined with trap-based biorational spraying can control the ESFB, provided at least 22 traps are present on nearby fields covering roughly 0.4 ha area.

I did not observe compatibility problems between IPM components for disease or insect management. For example, when hot water treatments were combined with soil application of T. harzianum or when improved seedlings were transplanted to T. harzianum amended field soil or when biorational was sprayed in pheromone trapped field, none of the IPM components for each management practice compromised the other components. Here, one exception has to be noted: whether soil application of T. harzianum would be compatible with farmers' present sowing rate cannot be answered. In the nursey management study (Chapter 2), upon negotiation with farmers, seed rate was reduced 2-4 times compared with their conventional seed rate. As T. harzianum seems to improve emergence of seedlings both by enhancing germination and by reducing pre-emergence damping-off, in the case in which seed rate will be high, the effect of T. harzianum may be compromised due to seed to seed and seedling to seedling contamination. Therefore, to maintain the effect of $T$. harzianum on seedling quality, sowing rate needs to be reduced.

Farmers could either practise the disease management strategy or the insect management strategy. However, integration of both strategies would be best. Because more plants surviving from wilt will lead to more fruits and more of those extra fruits will remain free of ESFB damage; therefore, there will be an additive effects when management of disease and insects would be combined. Whether proposed disease and insect management are compatible cannot be assessed from the present thesis; however, it is not likely that soil application of T. harzianum will affect pheromone trapping and vice versa. The farmers' practice of conventional spraying 
was neither effective against the nursery and field diseases (damping-off, wilt and rot, respectively) nor against the ESFB. Rather, the farmers' practice for ESFB control was harmful for natural enemies such as predatory ladybird beetles and the parasitoids Trichogramma spp. and Bracon spp. (Chapter 4). Moreover, it has been reported that frequent spraying affects the aquatic ecosystem (Sumon et al., 2018) and affects farmers' health (Akter et al., 2018) in the study area. In reality, farmers might feel that it is challenging and risky to try IPM for both disease and insect management. In that case, they can go for either disease or insect IPM first. It has been reported that farmers usually try out IPM in a piece-wise fashion but not as a fixed package (Shepard et al., 2009; Peshin, 2013). Therefore, I suggest farmers should start with the damping-off management in the nursery (Chapter 2). It only requires soil amendment of $T$. harzianum and the amount of $T$. harzianum needed will be limited compared with field application. The addition of a hot water treatment can be considered. Because, after the joint experimentation, farmers understood that this treatment did not compromise the germination of seeds, rather it enhanced germination. Field soil amendment of T. harzianum in addition to the nursery can also be recommended (Chapter 2). Farmers may even consider using T. harzianum only in the field soil but not in the nursery; it was also effective but costs more than nursery treating (Chapter 2). The choice farmers will eventually make will depend on their interest in using each IPM option and their ability to analyse which one would be more profitable for them. The choice of the farmers will also depend on the availability of materials. If T. harzianum is scarce, farmers can best only treat the nursery. If farmers cannot treat the nursery as $T$. harzianum is not timely available because of transport problems at the end of the rainy season when nurseries are planted, it is still worthwhile considering treating the field.

For management of ESFB, there are also various options. Farmers can either choose only pheromone trapping or add biorational spraying to trapping. Both practices reduced fruit infestation, improved marketable yields and farmers' income at input costs in terms of cash and labour comparable with those of farmers' practice. Based on single trap monitoring on a few plots, we recommended installing traps for mass trapping after moths were first trapped 25-30 days after transplanting (DAT). Use of only pheromone trapping and refraining from insecticide use will be challenging for farmers used to calendar-based spraying. Therefore, suggesting combining trapping with limited biorational spraying as fall-back option could be more appealing to them, providing also control against sucking insect populations building up to damaging levels and thereby alleviating the risk of failure of introducing a new pest management strategy (Chapter 4). 


\section{Chapter 6}

In the ESFB management study (Chapter 4), pheromone trapping was tested in a network of nearby fields (3-6 nearby fields at 10-25 m distance each having 4-12 traps forming a cluster of 22-55 traps). As mentioned earlier, pheromone trapping was found technically and economically sound. However, it was unclear if trapping effects would also be observed when a single small field would be treated stand-alone. In Chapter 5, I found that trapping was ineffective when carried out on individual small fields that allowed placement of just 4 traps, a field size typical for smallholder eggplant farmers. In contrast, trapping was effective when placed as a 24-trap array $(10 \mathrm{~m} \times 10 \mathrm{~m}$ grid of $4 \times 6$ traps $)$ or as a network of nearby fields. This indicates that concerted action among smallholder farmers is required for trapping to be effective. Based on the findings of Chapter 5, I suggest farmers to either create a network of at least 22 traps on nearby fields covering roughly 0.4 ha or organise themselves as direct neighbours to form a continuous $10 \mathrm{~m} \times 10 \mathrm{~m}$ grid of 24 or more traps (Chapter 5, Fig. 1). However, what would be the exact minimum number of traps for effective trapping requires further research. In our previous study over two years on ESFB management, trapping in the network was cost-effective (Chapter 4); therefore, trapping by installing a continuous array of 24 traps would also be cost-effective. Installing 24 traps would require 3-4 farmers who need to organise themselves while sharing the costs and labour. At present, it seems extension personnel in Bangladesh including farmer field school trainers are not aware of the need to have a minimum size network to make sure local depletion is not outweighed by additional attraction. The minimum need for organisation was not indicated in any of the analysed IPM training materials. While this analysis was limited to a single country in Southeast Asia, I assume the same is likely true for training materials and farmer field school training in other countries as also AVRDC (Asian Vegetable Research and Development Centre), reporting on the use of pheromone traps, does not address this complication (Alam et al., 2003; Cork et al., 2005).

IPM is poorly adopted when offered as a predefined package (Morse and Buhler, 1997; Parsa et al., 2014). Such packages often fail to meet the needs of farmers (Morse and Buhler, 1997). IPM is also poorly adopted when it combines many options in a package for example cultural, physical, mechanical, biological options of pest control. Combining many components in a complementary way might satisfy the philosophy of IPM; however, whether it will be able to suit farmers is questionable. That is, farmers, particularly smallholders in the developing world, have limited labour, knowledge, and economic buffering capacity. In Bangladesh, farmers are recommended to practise grafting of eggplant seedlings with wild rootstock to produce healthy seedlings, soil fumigation, and use of resistant varieties to control bacterial wilt, but this all has 
limited success and adoption (Vanitha et al., 2009; Rahman et al., 2010). In this thesis, while jointly experimenting with farmers, I crafted options for farmers that are effective as a single component or as a combination of two components maximum. Moreover, I found that the same options worked for both wilt and fruit rot management. Particular control measures for each disease would not only be difficult for smallholder farmers to implement but might also be expensive. Instead of providing pre-defined "ready-made IPM", farmers should rather be provided with a basket of options so that they can try-out, adapt and adopt ( as also advocated by Meerman et al., 1997). Because the IPM options from this study were designed together with farmers they are most likely to be taken up by farmers. However, there are still bottlenecks for the use of these IPM options and without removing those, sustained use of this IPM by the participant farmers and scaling out this crafted IPM to other will not be possible.

\section{Remaining bottlenecks of IPM options and possible ways to alleviate them}

The thesis provided a 'basket of options' for farmers all of which were proven to be technically and economically sound. Yet, there are also several remaining bottlenecks in the tested IPM options that will be explained each in more detail:

i) unavailability of IPM materials in the village;

ii) farmers' inability to comprehend ESFB biology;

iii) social organisation needed for pheromone trapping;

Regarding the first point: For improved nursery and field disease management, requirements include a seed treating machine and Trichoderma formulation. Both are not available in the village at this moment. These are only available with Bangladesh Agricultural University (BAU) where these were researched and invented, around $80 \mathrm{~km}$ from the study area. Similarly, pheromone lures, traps and biorational insecticide for ESFB control are currently not available in the village. None of the materials are sold in the nearby agro-input shops. Traps and lures are sold by the manufacturing company agent or by enthusiastic farmer trainers of local farmer field schools (FFS) who see this as a 'green business'. Biorational insecticides are sold by major pesticide dealers only. In contrast, farmers can easily buy chemical pesticides from local shops just a doorstep away. While disease and insect management studies presented in this thesis show these chemical pesticides are actually ineffective and the IPM options much more effective, unavailability of these IPM materials can make all IPM options practically ineffective to farmers. Low IPM adoption due to unavailability of IPM materials has been reported earlier 


\section{Chapter 6}

in Bangladesh and other developing countries (Muthuraman and Sain, 2002; Borkhani et al., 2010; Parsa et al., 2014; Kabir and Rainis, 2015). To alleviate the unavailability of IPM materials, village level enterprises by enthusiastic farmer trainers or farmers or village youth can be established. In this regard, help from local extension (upazilla agriculture office) is required. In Bangladesh, FFSs are run by local extension in the villages with predominant vegetable cultivation. On completion of the farmer field school, farmers are suggested to start an IPM club where trained farmers not only discuss the crop management issues but also save money to buy inputs and machineries that are required for improved crop management. Given this role and set-up IPM clubs could become instrumental in changing availability if agro-input shops fail. IPM club members could buy the seed treating machine and help all farmers to treat seeds on a payment basis. As electricity is available in most of the villages of Bangladesh, operating the machine does not seem to be problematic. For Trichoderma, enthusiastic farmers (especially women) and youth of the village or farmer trainers of the local field school could be trained on Trichoderma preparation so that they can set up their own business and sell the product. Local extension could ask the IPM laboratory of BAU to provide the training or at least the training materials for farmers and IPM clubs and provide the starting materials at a reasonable price. Farmer trainers who are enthusiastic about setting a 'green business' should be supported by government. Given the time and effort spent in creating IPM FFS and promoting IPM with farmers the government should also consider supporting development of the related input value chain to avoid farmers are trained in using materials that are not on the market. Extension might also inform the local agro-input dealers about these materials and encourage them to sell these.

Regarding the second point: To understand the mechanism of mass trapping by pheromone traps and trap-catch-based timely spraying of biorational insecticide, it is necessary that farmers have knowledge on the ESFB life cycle. Farmers were found to have no inkling that caterpillars are the juvenile stage and moths are the adult stage of the same organism. Moths are nocturnal and they rarely can be seen at day time. When farmers saw moths in the traps they were surprised and asked how this trapping would reduce infestation because it is the caterpillar that causes damage to the fruits (Chapter 4, Table 2). Farmers have no idea that caterpillars are born from eggs, pass their juvenile stages inside fruits, exit fruits to pupate in the soil or plant debris, and afterwards transform into moths. When I explained to them that pheromone traps attract male moths, thereby gradually depleting the moth population and hampering mating success and thereby reducing infestation, farmers raised another question: why do traps not catch female 
moths? Moreover, there was a lag phase between trap catch and infestation. Therefore, due to farmers' limited understanding on biology, it was hard for them to understand why there were many moths in the traps when fruits are not yet very infested and then 2-3 weeks later fewer moths in the traps but there were many infested fruits. After trap installation, it took 1-2 life cycles (roughly 30-60 days) to build up to a tangible effect as shown when plotting the data (Chapter 4, Fig. 2c,d). It remains difficult for farmers to understand the effect of trapping and thereby at the first few harvests, farmers doubted the effect of trapping. For biorational spraying, I guided the farmers to spray based on careful monitoring of trap catches and spraying was done within a week after trap catches averaged more than four moths per trap to target the eggs or first instar caterpillars that live outside the fruit. Farmers had difficulty in understanding this rationale of biorational spraying, again because of a lack of knowledge on the life cycle and related vulnerability to spraying. Without a sufficiently clear understanding of insect biology and related aspects mentioned above, farmers may not be able and expected to implement mass-trapping-based IPM of the ESFB. Many researches already revealed that farmers' knowledge gap on crop pest biology contributes to low IPM adoption, influence their pest management decision and make them dependent on pesticides (Robinson 2007; Bentley et al., 2009; Litsinger et al., 2009; Wyckhuys et al., 2007, 2013, 2019; Mkenda et al., 2020). Other studies also reported low adoption of IPM due to farmers' knowledge gap on insect biology (Orr et al., 2001). In sweet potato weevil management in Malawi, farmers did not understand the rationale of sealing soil cracks, because they could not connect the adult weevil observed in the soil and the larvae found inside the tubers (Orr et al., 1998). Successful implementation of IPM depends on improving farmers' knowledge on pest biology, particularly the life cycle (Orr, 2001).

Farmers' knowledge on insect life cycle may be improved by experiential learning. Indeed, sustainable agriculture requires experiential learning (Leeuwis and Pyburn, 2002; Van de Fliert, 2003). In this regard, FFSs could play a role. The life cycle of ESFB can be monitored jointly in a cage study and the different stages of the insect's life cycle could then be shown and their relation explained to farmers. Alternatively, a video of the life cycle can be shown and related to what farmers can observe in their field. It has been reported that video-mediated learning enhanced farmers' knowledge on botanical pesticide preparation compared with conventional lectures in Bangladesh (Chowdhury et al., 2015). In another study on rice seed innovation in Benin and Bangladesh, video-mediated learning improved farmers' understanding on underlying principles of the technology (Van Mele, 2006). 


\section{Chapter 6}

In theory, the FFS approach suggests to not use much lecturing (Gallagher, 2003), rather emphasize on joint field observations. However, it has been reported that lecturing is most widely used instead of participatory field observations (Winarto, 2004; Palis, 2006). From my personal experience of an IPM FFS targeted to eggplant farmers, there was no life cycle demonstration of ESFB; also after putting pheromone traps in a field of one randomly chosen participant farmer, there was no monitoring of infestation. This lack of field observations and in-field discussions may have contributed to the farmers' poor understanding of insect biology and thus poor adoption of IPM. This would be in line with the findings of Robinson et al. (2007), where rice IPM FFS trained farmers of Bangladesh could not identify plant hopper nymphs; most farmers thought the nymphs were related to a stem borer moth, an entirely different insect from plant hopper. I would argue that FFS learning should be more field-oriented.

Regarding the third point: Chapter 5 confirmed that trapping as an individual field (4-trap) was ineffective. Traps provided effective control when traps were placed as $10 \mathrm{~m} \times 10 \mathrm{~m}$ grid of 24 traps or network of nearby fields (Fig 1 C). Trapping requires concerted action of farmers. Installing 24 traps would require 3-4 farmers (direct neighbours) who need to organise themselves while sharing the costs and labour. Network of fields also requires organisation among farmers. I also found that when traps were organised as a 24-trap array, centre plots were better protected than corner plots. This might create tension among farmers. Also, when traps will be organised as network of farmers, in between there will be fields without traps that will get benefit as free rider. All those factors might create conflicts among farmers. Without concerted and social organisation among farmers, trapping might not be effective. This is a major bottleneck for applying pheromone-based mass trapping for smallholders. To alleviate this bottleneck, the necessity of farmers' collective action needs to be explained to farmers in FFS training. Farmers involved in IPM clubs should thus also organise themselves to comply with this required minimum density.

\section{Reflection on research approach used: crafting the basket}

Engaging farmers from the very beginning was the most important element of the research presented in this thesis. For each study (Chapters 2, 3, 4), except for the research reported in Chapter 5, farmers were intimately engaged through negotiating treatments, implementing and aftercare of the treatments wherever possible (mixing $T$. harzianum in soil, installing pheromone traps, changing water in traps; all supervised by the researcher). Moreover, monthly meetings were held to understand their views and worries to learn about treatments. Also, 
formal and informal discussions were held in the field to learn from each other. Farmers were also engaged in the assessment of different improved treatments. Simultaneously, I conducted laboratory and screen house studies to identify the source of infection and the relative role of treatment components.

Farmers' involvement in the research enabled me to put the research in the proper context and to come up with a basket of options that are technically reliable and also feasible in the present farming context. This also helped me to realize the bottlenecks of the different options. I proposed IPM elements based on scientific literature and discussions with scientists from Bangladesh Agriculture University and other relevant agricultural research institutes in the country, while also farmers had their ideas to propose. For example, they strongly suggested to test a seed treatment with Carbendazim (Chapter 2) and to add conventional insecticide spraying in the pheromone trap treated fields (Chapter 4). I also learned about their worry of boiling seeds when using the hot water treatment machine; and their worry of attracting insects from neighbouring fields if they would install traps as a single farmer. The latter worry led to an extra field study reported in Chapter 5. Discussion with farmers revealed that labourintensive IPM will not work for them (Chapter 4) because they opposed the proposal of sanitation of the crop by hand (regular removal of infested shoots and fruits). Rather than testing it by paying them for the work the decision was to drop the treatment as not applicable.

Apart from the participatory study with farmers, I did several in vitro and screen house studies to figure out the source of infection and to disentangle the relative role of IPM components. I learned that soil is the main source of the pathogens causing damping-off, seed and soil both are the sources of the pathogens causing wilt and rot, and Trichoderma is the main player to reduce all those diseases, thus corroborating the findings from the on-farm experiments.

\section{What is to be considered while developing IPM for developing countries: lessons learned from this study}

\subsection{Ensure engagement of farmers in the research and attention to farmers' needs}

Involving farmers in the research helps understand the needs and aspirations of farmers within their context. When farmers are involved in the research and their needs are taken into consideration, the research findings and recommendations become more relevant to farmers (Pretty, 1998; Sinzogan, 2006). Initially, my research focus was only on an insect, i.e. the ESFB. While discussing with farmers I learned that, apart from ESFB, there were a few disease 


\section{Chapter 6}

problems relevant to farmers: damping-off in the homestead nursery and bacterial wilt and fungal rot in the production field. It seemed farmers would not value a participatory study of ESFB unless these disease problems were also taken seriously. Indeed, farmers often mentioned "If we don't have plants, where will we apply IPM for ESFB?" in reference to the need to tackle their problem with plant loss to wilt (Chapter 4, Table 2). What researchers consider a problem might not be the only problem to farmers. Addressing wrong problems can cause low IPM adoption (Orr and Ritchi, 2004). When farmers are involved in the research and their problems are taken seriously, farmers feel assured, sense ownership of the study and thus become motivated to actively participate in the research. For example, in this study, when I decided together with farmers that IPM options for both insect and disease problems would be tested, farmers became more interested in the study. With full enthusiasm, they welcomed me, allocated their lands for treatment deployment and actively participated in the group discussions and field observations. Treatment negotiation with farmers allowed me to understand their urge to test insecticides with researcher proposed IPM options. For example, chemical seed treatment with Carbendazim for damping-off management in the nursery, conventional spraying with pheromone trapping for ESFB management in the field. Because of their interest in using pesticides with IPM options, while discussing benefits of biorational insecticides over conventional insecticides, it was decided to also test a biorational insecticide with pheromone trapping. Also, in the ESFB management study of year 1, when it was realized that conventional insecticide spraying did not provide any further control beyond only pheromone trapping but it killed natural enemies, the decision was taken together to not include this spraying in the year 2 study. When sanitation (removal of infested shoots and fruits) was proposed to the farmers, they immediately rejected this, considering it too labour-intensive. When a hot water seed treatment was proposed in the damping-off management study, farmers initially questioned whether it would kill the seeds or inhibit seed germination. Believing the researcher's explanation that it was safe, farmers agreed to test it in year 1. When farmers' saw better seedling emergence in improved management plots compared with their conventionally managed plots, their worry about seed boiling had completely gone. They agreed to keep this seed treatment in the year 2 study. Hence, engaging farmers in the present study not only helped figure out the relevant problems of farmers to be researched, but also helped find out IPM options relevant to them. Indeed, farmers' participation in experimentation allows much better than on-station research to assess what is achievable under farmers' conditions rather than what is technically perfect (Morse and Buhler, 1997; Morse, 2009). However, conventional 
agricultural research often neglects farmers' needs, does not engage farmers in the research and provides researchers' recipe to farmers; such technology often failed, and farmers follow their own agenda (Röling, 1988; Matteson et al., 1994; Röling, 1996; Morse and Buhler, 1997; Van Huis and Meerman, 1997; Parsa et al., 2014). Based on my own experience and the related literature $t$, I conclude that while developing IPM, researchers need to pay attention on farmers' needs and socio-economic contexts.

\subsection{IPM options should not be labour-intensive}

Smallholder and resource-poor farmers will not favour labour-intensive IPM strategies (Goodell et al., 1990; Beckman and Wesseler, 2003). In the ESFB management study (Chapter 4), I proposed farmers to test sanitation (removal of infested shoots and fruits) as one of the IPM components. Among eight participants, six farmers immediately rejected it. Two enthusiastic farmers started it, however, after a week they dropped it as it was too complex and laborious. In Bangladesh, eggplant farmers are suggested by research and extension to practise regular sanitation. However, this practice was poorly adopted (Kabir and Rainis, 2015), reason might be labour intensiveness. Rice farmers of Bangladesh were also taught by FFSs to practise leaf clipping, netting and insect scouting; however, farmers continued to use pesticides as they considered all these practices too labour intensive (Robinson et al., 2007). Rejection of labour intensive practices was also reported from elsewhere, for example, African farmers rejected earthing-up, mulching, and sanitation (Orr and Ritchi, 2004; Togbe et al., 2015). Farmers in the developing world in fact require IPM options that require limited labour. While designing IPM, this practicality needs to be kept in mind.

\subsection{Rational pesticide use should be kept as an IPM component}

Vegetable farmers of South and Southeast Asia, including Bangladesh, heavily depend on pesticide use for insect and disease control (Gautam et al., 2017; Schreinemachers et al., 2017, 2020). Eggplant farmers of Bangladesh apply pesticides weekly (Chapter 4, Mohiuddin et al., 2009; Shelton et al., 2018). Recommending them not to use any pesticide might be in vain. For example, one of the important components of the previously developed ESFB IPM was not to use any pesticide (Alam et al., 2006). I surmise this is one of the main reasons why farmers rarely adopt that IPM. In my study, when I negotiated treatments with farmers, they demanded to include pesticide for each disease and insect management study (Chapters 2, 3, 4). For instance, farmers tested a seed treatment with Carbendazim in the damping-off management 


\section{Chapter 6}

study (Chapter 2) and conventional insecticides spraying with pheromone trapping in the ESFB management study (Chapter 4). Yet, in the latter study farmers dropped the conventional insecticide spraying combined with pheromone trapping after the year 1 study because this spraying did not provide further control beyond trapping but killed natural enemies; I argue that these farmers might not go for only trapping because they are habituated with pesticide spraying. Moreover, farmers wanted to keep pesticide treatments also to avoid uncertainty of the efficacy of IPM materials. Because, these farmers are smallholders and if the IPM fails they will live the dire economic consequence. Apart from ESFB, there were minor insects, for example aphids and jassids, in the eggplant fields. Farmers' spraying of broad spectrum insecticides reduced their population (Chapter 4). When only pheromone trapping would be used, these minor insects might appear as major; farmers will then again return to spraying. To prevent this, I suggest to keep biorational insecticide spraying with pheromone trapping as biorational spraying reduced the aphids and jassids populations (Chapter 4). Although there is debate whether a full strategic IPM should use pesticides (Morse and Buhler, 1997), for making IPM adoptable, a complete devoid of pesticide use will not work for these farmers. Farmers are not yet ready to use a fully strategic IPM. Therefore, keeping pesticide use but replacing broad spectrum formulations by biorational ones and then convert to monitoring-based application would be a fall-back option for farmers (Chapter 4).

\subsection{Keeping IPM components that are easy to understand}

Farmers of Bangladesh are habituated with pesticide spraying. In this context, shifting from spraying to IPM would require: introducing an IPM components that are not difficult to practise compared with spraying; also, the effect of the IPM component should be visible. For instance, in this thesis, soil application of T. harzianum was much more appreciated by farmers than pheromone trapping. T. harzianum required mixing an amendment into the soil just one time before broadcasting seed in the nursery and transplanting seedling in the field. Effect of $T$. harzianum was visible within two weeks from the seedling growth, less failure of seedlings in the nursery and later also from less plant death in the field. In contrast, although farmers stated maintaining traps is not difficult, understanding the trapping mechanism and observing the effect of trapping was difficult. With proper provisioning of the IPM materials and farmers' training, I understand farmers might pick up the application of $T$. harzianum before they go for trapping. 


\section{Personal reflections and concluding remarks}

Since its inception 70 years ago, IPM has changed over time and today it has a strong conceptual basis. This change mainly focused on technical excellency of IPM by combining and experimenting multiple complimentary tactics, for instance cultural, biological, physical and mechanical methods. IPM also strongly focused on maintaining environmental benefits and 'ecological services' other than production. However, whether the IPM would match farmers' knowledge, labour, and economics remained neglected. While developing IPM, researchers should not determine IPM components strictly based on the IPM philosophy, rather they should think rationally - both from a technical and practical implementation view point - what would be best for farmers. Researchers must have good grounding on the philosophy of IPM but must also have the capacity to readjust the IPM to farmers' needs without strictly sticking to the IPM philosophy. For instance, I learned from this thesis that farmers still want to do some spraying; therefore, biorational spraying was included in the ESFB management study. The strategic components of IPM (like mass trapping and not using pesticides) are priority; however, including rational use of a selective pesticide together with strategic components would not deviate fundamentally from the philosophy of IPM. I also learned from my research that other than a single organism, all organisms that are most relevant to farmers should be taken into account while designing IPM. For instance, I started my $\mathrm{PhD}$ research focusing on an insect only, namely ESFB; however, while interacting with farmers, I understood that there were more equally compelling problems (diseases: damping-off, bacterial wilt and fungal fruit rot); not considering diseases in the research would have made the research less interesting to farmers, and this would have made them less interested in IPM as a concept too. What IPM means to the researchers matters, yet taking into account what IPM means to farmers will help make them adopt IPM. Otherwise, IPM will remain elusive to the vast majority of farmers in developing countries.

\section{References}

Akter, M., Fan, L., Rahman, M. M., Geissen, V., Ritsema, C. J., 2018. Vegetable farmers' behaviour and knowledge related to pesticide use and related health problems: A case study from Bangladesh. Journal of Cleaner Production, 200: 122-133.

Alam, S. N., Rashid, M. A., Rouf, F. M. A., Jhala, R. C., Patel, J. R., Satpathy, S., Shivalingaswamy, T. M., Rai, S., Wahundeniya, I., Cork, A., Ammaranan, C., Talekar, N. S., 2003. Development of an integrated pest management strategy for eggplant fruit and shoot borer in South Asia. Technical Bulletin No. 28. AVRDC Publication No. 03-548. AVRDC-the World Vegetable Center, Shanhua, Taiwan. 56 pp. 


\section{Chapter 6}

Alam, S. N, Hossain, M. I., Rouf, F. M. A., Jhala, R. C., Patel, M. G., Rath, L. K., Sengupta, A., Baral, K., Shylesha, A. N., Satpathy, S., Shivalingaswamy, T. M., Cork, A., Talekar, N. S., 2006. Implementation and promotion of an IPM strategy for control of eggplant fruit and shoot borer in South Asia. Technical Bulletin No. 36. AVRDC publication number 06-672. AVRDC - The World Vegetable Center, Shanhua, Taiwan. 74 pp.

Alwang, J., Norton, G., Larochelle, C., 2019. Obstacles to Widespread Diffusion of IPM in Developing Countries: Lessons From the Field. Journal of Integrated Pest Management, 10: 10.

Beckmann, V. and Wesseler, J., 2003. How labour organization may affect technology adoption: an analytical framework analyzing the case of integrated pest management. Environment and Development Economics, 8: 437-450.

Bentley, J. W., 2009. Impact of IPM Extension for Smallholder Farmers in the Tropics. In: Peshin, R., Dhawan, A. K. (Eds.), Integrated Pest Management: Dissemination and Impact. Springer, Dordrecht, pp. 333-346.

Borkhani, F. R., Fami, H. S., Rezvanfar, A., Pouratashi, M., 2010. Investigating the major barriers to adoption of IPM technologies by paddy farmers. American-Eurasian Journal of Toxicological Sciences, 2: 146-152.

Bottrell, D. G. and Schoenly, K. G., 2018. Integrated pest management for resource-limited farmers: challenges for achieving ecological, social and economic sustainability. The Journal of Agricultural Science, 156: 408-426.

Chowdhury, A., Odame, H. H., Thompson, S., Hauser, M., 2015. Enhancing farmers' capacity for botanical pesticide innovation through video-mediated learning in Bangladesh. International Journal of Agricultural Sustainability, 13: 326-349.

Cork, A., Alam, S.N., Rouf, F.M.A., Talekar, N. S., 2005. Development of mass trapping technique for control of brinjal shoot and fruit borer, Leucinodes orbonalis (Lepidoptera: Pyralidae). Bulletin of Entomological Research, 95: 589-596.

Gallagher, K. 2003. Fundamental elements of a farmer field school. LEISA Magazine, 19: 5-6.

Gautam, S., Schreinemachers, P., Uddin, M. N., Srinivasan, R., 2017. Impact of training vegetable farmers in Bangladesh in integrated pest management (IPM). Crop Protection, 102: 161-169.

Goodell, G., Andrews, K. L., López, J. I., 1990. The contributions of agronomo-anthropologists to onfarm research and extension in integrated pest management. Agricultural Systems, 32: 321-340.

Kabir, M. H. and Rainis, R., 2015. Do farmers not widely adopt environmentally friendly technologies? Lesson from Integrated Pest Management (IPM). Modern Applied Science, 9: 208.

Litsinger, J. A., Libetario, E. M., Canapi, B. L., 2009. Eliciting Farmers' Knowledge, Attitudes, and Practices in the Development of Integrated Pest Management Programs for Rice in Asia. In: Peshin, R., Dhawan, A. K. (Eds.), Integrated Pest Management: Dissemination and Impact. Springer, Dordrecht, pp. 119-273. 
Leeuwis, C. and Pyburn, R., 2002. Social Learning for Rural Resource Management. In: Leeuwis, C., Pyburn, R. (Eds.), Wheelbarrows Full of Frogs. Social learning in Rural Resource Management. Koninklijke Van Gorcum, Assen, pp.1-23.

Matteson, P. C., Gallagher, G. D., Kenmore, P. E., 1994. Extension of Integrated Pest Management of Plant hoppers in Asian Irrigated Rice: Empowering the User. In: Denno, R. F., Perfect, T. J. (Eds.), Ecology and Management of Plant hoppers. London: Chapman and Hall, pp. 656-685

Meerman, F., Bruinsma, W., Vanhuis, A., Terweel, P., 1997. Integrated pest management: smallholders fight back with IPM. ILEIA newsletter.

Mkenda, P. A., Ndakidemi, P. A., Stevenson, P. C., Arnold, S .E., Darbyshire, I., Belmain, S. R., Priebe, J., Johnson, A. C., Tumbo, J., Gurr, G. M., 2020. Knowledge gaps among smallholder farmers hinder adoption of conservation biological control. Biocontrol Science and Technology, 30: 256-277.

Mohiuddin, M., Hossain, M. M., Rahman, A. K. M. M., Palash, M. S., 2009. Socio-economic study of insecticide use on vegetable cultivation at farm level in Chittagong region. Journal of the Bangladesh Agricultural University, 7: 343-350.

Morse, S. and Buhler, W., 1997. IPM in developing countries: the danger of an ideal. Integrated Pest Management Reviews. 2: 175-185.

Morse, S. 2009. IPM, Ideals and Realities in Developing Countries. In: Radcliffe E. B., Hutchison, D., Cancelado, R. E. (Eds.), Integrated Pest Management: Concepts, Tactics, Strategies and Case Studies. Cambridge university press, pp. 458-470.

Muthuraman, P. and Sain, M., 2002. Sociology of integrated pest management in rice. Resources management in plant protection during twenty first century, Hyderabad, India. II, 14-15. http://www.cababstractplus.org/abstracts/Abstract.aspx? AcNo=20043048767.

Orr, A., Mkandawire, B., Koloko, A., Milanzi, T., Kapalula, P., 1998. Sweet potato trial, 1997/98: farmer diagnosis and evaluation, with economic analysis. Farming Systems Integrated Pest Management Project, Department of Agricultural Research and Technical Services, Malawi.

Orr, A., Mwale, B., Saitis, D., 2001. What is an integrated pest management 'strategy'? Explorations in Southern Malawi. Experimental Agriculture, 37: 473-494.

Orr, A. and Ritchie, J. M., 2004. Learning from failure: smallholder farming systems and IPM in Malawi. Agricultural Systems, 79: 31-54.

Palis, F. 2006. The role of culture in farmer learning and technology adoption: A case study of farmer field schools among rice farmers in Central Luzon. Agriculture and Human Values. Yale Southeast Asia Studies, New Haven, Connecticut, 429 pp.

Parsa, S., Morse, S., Bonifacio, A., Chancellor, T. C. B., Condori, B., Crespo-perez, v., Hobbs, S. L. A., Kroschel, J., Ba, M. N., Rebaudo, F., Sherwood, S. G., Vanek, S. J., Faye, E., Herrera, A., Dangles, O., 2014. Obstacles to integrated pest management adoption in developing countries. Proceedings of the National Academy of Sciences, 111: 3889-3894. 


\section{Chapter 6}

Peshin, R., 2013. Farmers' adoptability of integrated pest management of cotton revealed by a new methodology. Agronomy for Sustainable Development, 33: 563-572.

Pretty, J. N., 1998. Participatory Learning in Rural Africa: Towards Better Decisions for Agricultural Development. In: Coenen, F. H. J. M., Huitema, D., O’Toole, L. G. (Eds.), Participation and the Quality of Environmental Decision Making. Springer, Dordrecht, pp. 251-266.

Rahman, M. F., Islam, M. R., Rahman, T., Meah, M. B., 2010. Biochemical characterization of Ralstonia solanacerum causing bacterial wilt of brinjal in Bangladesh. Progressive Agriculture. 21: 9-19.

Robinson, E. J .Z., Das, S. R., Chancellor, T. B. C. 2007. Motivations behind farmers' pesticide use in Bangladesh rice farming. Agriculture and Human Values, 24: 323-332.

Röling, N. G. 1988., Extension Science: Information System in Agricultural Development. Cambridge: Cambridge University Press. 233 pp.

Röling, N. G., 1996., Towards an interactive agricultural science. European Journal of Agricultural Education and Extension, 2: 35-48.

Schreinemachers, P., Chen, H. P., Nguyen, T. T. L., Buntong, B., Bouapao, L., Gautam, S., Le, N. T., Pinn, T., Vilaysone, P. and Srinivasan, R., 2017. Too much to handle? Pesticide dependence of smallholder vegetable farmers in Southeast Asia. Science of the Total Environment, 593: 470477.

Schreinemachers, P., Grovermann, C., Praneetvatakul, S., Heng, P., Nguyen, T.T.L., Buntong, B., Le, N.T. , Pinn, T., 2020. How much is too much? Quantifying pesticide overuse in vegetable production in Southeast Asia. Journal of Cleaner Production, 244: 118738.

Shelton, A. M., Hossain, M. J., Paranjape, V., Azad, A. K., Rahman, M. L., Khan, A. S. M. M. R., Prodhan, M. Z. H., Rashid, M. A., Majumder, R., Hossain, M. A., Hussain, S. S., 2018. Bt eggplant project in Bangladesh: history, present status, and future direction. Frontiers in Bioengineering and Biotechnology, 6: 106.

Shepard, B. M., Hammig, M. D., Carner, G. R., Ooi, P. A. C., Smith, J. P., Dilts, R., Rauf, A., 2009. Implementing Integrated Pest Management in Developing and Developed countries. In: Peshin, R., Dhawan, A. K. (Eds.), Integrated Pest Management: Dissemination and Impact. Springer, Dordrecht, pp. 275-305.

Sinzogan, A. A., 2006. Facilitating learning toward sustainable cotton pest management in Benin: the interactive design of research for development. $\mathrm{PhD}$ dissertation, Wageningen University, Wageningen, The Netherlands.

Sumon, K. A., Rashid, H., Peeters, E. T., Bosma, R. H., Van den Brink, P. J., 2018. Environmental monitoring and risk assessment of organophosphate pesticides in aquatic ecosystems of northwest Bangladesh. Chemosphere, 206: 92-100.

Togbé, C. E., Haagsma, R., Aoudji, A. K., Vodouhê, S. D., 2015. Effect of participatory research on farmers' knowledge and practice of IPM: the case of cotton in Benin. Journal of Agricultural Education and Extension, 21: 421-40. 
Van de Fliert, E., 2003. Recognising a climate for sustainability: Extension beyond transfer of technology. Australian Journal of Experimental Agriculture, 43: 29-36.

Van Huis, A. and Meerman, F. 1997. Can we make IPM work for resource poor farmers in Sub-Saharan Africa? International Journal of Pest Management. 43: 313-320.

Vanitha, S. C., Niranjana, S. R., Mortensen, C. N., Umesha, S., 2009. Bacterial wilt of tomato in Karnataka and its management by Pseudomonas fluorescens. Biocontrol 54: 685-695.

Van Mele, P., 2006. Zooming-in zooming-out: A novel method to scale up local innovations and sustainable technologies. International Journal of Agricultural Sustainability, 4: 131-142.

Winarto, Y. T., 2004. Seeds of Knowledge: The Beginning of Integrated Pest Management in Java.

Wyckhuys, K. A. and O’Neil, R. J., 2007. Local agro-ecological knowledge and its relationship to farmers' pest management decision making in rural Honduras. Agriculture and Human Values, 24: 307-321.

Wyckhuys, K. A. G., Lu, Y., Morales, H., Vazquez, L. L., Legaspi, J. C., Eliopoulos, P. A., Hernandez, L. M., 2013. Current status and potential of conservation biological control for agriculture in the developing world. Biological Control, 65: 152-167.

Wyckhuys, K. A., Heong, K. L., Sanchez-Bayo, F., Bianchi, F. J., Lundgren, J. G., Bentley, J. W., 2019. Ecological illiteracy can deepen farmers' pesticide dependency. Environmental Research Letters, 14: 093004. 



\section{Summary}

In response to the unrestricted use of pesticides, the concept of integrated pest management (IPM) was developed in the1960s. It matured over time and was strongly promoted. Millions of farmers across the globe have been trained through the Farmers' Field School approach, mainly in developing countries. Despite huge investments in IPM research and promotion, IPM is not embraced by farmers: its adoption rate remains frustratingly low. Various reasons for this include weaknesses in IPM research, poor quality of the proposed IPM, poor outreach, poor farmer training and organisation. While developing IPM, more attention has been given to technical excellence than to practical implementation.

This thesis aims to understand why IPM is so difficult to implement for smallholder farmers in developing countries and what is needed to make IPM work. Eggplant production in Bangladesh was taken as a case to contribute to this understanding. Eggplant farmers poorly adopted a previously recommended IPM; they spray broad-spectrum pesticides frequently (at least weekly) to control pests, more specifically the eggplant shoot and fruit borer moth. Involving farmers in the research, this study aimed to craft IPM options for smallholders that suit in their context, that maximally use natural enemies and that significantly reduce pesticide use. Simultaneously, based on joint experimentation with farmers, this study aimed to provide insights into how to break through the complexities and pitfalls of IPM to make it more adoptable for smallholder farmers.

The starting premise was to work on IPM for eggplant shoot and fruit borer (EFSB: Leucinodes orbonalis, Lepidoptera: Pyralidae). Based on discussions with farmers and field observations, I identified further major disease and insect problems of eggplants and then sought solutions for each of the problems together with these farmers. Relevant disease and insect problems to farmers were: damping-off (multiple fungal pathogens) in the homestead nursery, bacterial wilt (Ralstonia solanacearum) and fungal fruit rot (Phomopsis vexans) in the production field and indeed the original target insect ESFB infestation in the production field. For each of the disease and insect problems (Chapters 2, 3, 4), farmers' conventional practice of spraying proved ineffective. In contrast, a combination of IPM options available in the scientific literature but not all tested in the field were found to be technically sound and economically viable. Nonetheless, there were bottlenecks for the use of these IPM options.

Chapter 2 investigated a feasible disease management option for farmers' nursery problems with damping-off. I proposed soil application of Trichoderma harzianum (T. harzianum) and 
seed treatment with hot water while farmers proposed to include a chemical seed treatment with Carbendazim. A two-year participatory study was conducted in farmers' nurseries subject to damping-off and farmers' preserved seeds were used. On negotiation with farmers, sowing rate was reduced by a factor four both in improved management and farmers' practice plots in year 1 , farmers maintained the same sowing rate in the improved management plots in year 2 but followed their conventional sowing rate in the conventional practice plots. Soil application of T. harzianum combined with hot water seed treatment produced 25-64 percentage points more healthy seedlings than farmers' conventional practice of spraying. This combined treatment also improved seedling quality traits. Adding Carbendazim seed treatment with soil application of $T$. harzianum produced similar effects as including a hot water seed treatment. Therefore, it seems there were no compatibility issues when chemical seed treatment was combined with soil application of T. harzianum. Blotter and in vitro studies in the laboratory and tray studies in a screen house confirmed soil as the major source of the pathogen and T. harzianum as major player in both reducing damping-off and enhancing seedling growth. Farmers may go for only soil application of $T$. harzianum; however, the tested reduced sowing rate needs to be maintained. If they wish, they can also combine the soil application with a hot water treatment of the seed.

Chapter 3 investigated causes of bacterial wilt and fruit rot during the field stage and sought solutions with farmers to manage these two diseases. As more healthy and vigorous seedlings were produced from improved nurseries than in farmers' nurseries, the principal researcher and the farmers jointly decided to transplant these seedlings as a disease management option in the production field. Soil application of T. harzianum in the field was also chosen as another option. Finally, seedlings raised according to farmers' practice or in nursery soil treated with $T$. harzianum from seed treated either with hot water or with Carbendazim were transplanted in fields either with or without soil application of T. harzianum. Improved nursery management alone reduced wilt and fruit rot, increased marketable yield and farmers' income. An additional effect was found when T. harzianum was applied to the field soil as well. Only field soil application of T. harzianum was also found to be effective; this treatment was only tested in year 1 of the study because costs were higher than only transplanting improved seedlings (improved nursery management). To manage diseases in the production field, farmers are recommended to use the improved nursery management practices. Moreover, T. harzianum can be applied to the soil in the field; however, the practicality of this option will depend on the capacity of the farmers to invest additional labour and cash for input. T. harzianum persisted in 
the improved management fields at the end of the growing season and reduced wilt and rot pathogens. Seeds preserved from improved management showed less infection with pathogens than seed from farmers' practice plots. Reduction of pathogens at the end of the crop cycle both in the field soil and in preserved seed indicates that the next crop might start with lower disease pressure.

Chapter 4 explored the effectiveness, profitability and practicability of alternative ESFB control measures and compared their effects with the sole use of broad-spectrum synthetic pesticides. Based on the literature, I proposed pheromone trapping and removal of infested shoots and fruits (sanitation). Farmers immediately rejected the sanitation as too labourintensive. Farmers proposed combining conventional insecticide spraying with pheromone trapping. Understanding their desire to spray, I also proposed another treatment, trap-based biorational spraying, and informed farmers that biorationals are less detrimental to natural enemies and to the environment. Pheromone trapping alone or combined with biorational spraying reduced fruit infestation, increased yield and income at costs comparable to farmers' practice. These two IPM options did not affect predatory ladybird beetles or parasitoids. After a year of study, farmers dropped combining conventional insecticide spraying with pheromone trapping because spraying did not provide further control beyond pheromone trapping but reduced natural enemies. Farmers' practice neither reduced infestation nor increased yield compared to zero control plots but reduced populations of natural enemies. Although pheromone trapping only was effective, I advocate to keep biorational spraying as well, because farmers felt more assured when they also sprayed a biorational. Moreover, biorational spraying reduced the population ESFB further and reduced populations of aphids and jassids. If these minor insects increased, farmers would go back to conventional spraying. Farmers mentioned installing traps and changing water from traps is neither complex nor time consuming; however, farmers' lack of knowledge of ESFB biology is a major bottleneck; they need such knowledge to understand the trapping mechanism and its efficacy.

Chapter 5 explored the suitability of pheromone trapping for individual smallholder farmers versus trapping with a network of farmers. In Chapter 4, traps were installed in nearby fields of participant farmers which created network of fields with traps. Eggplant farmers are smallholders with fragmented land. There was a shared concern that the use of mass trapping for an individual farmer with a small plot would be ineffective; traps might attract male moths from surroundings outweighing local depletion. Therefore, I tested three types of trap settings: a 4-trap setting (individual small field), a 24-trap setting (combination of 3-4 adjacent fields, 
allowing an array of $4 \times 6$ traps) and a network setting (3-5 nearby fields at 10-25 m distance, each field having 4-12 traps forming three clusters at a distance of 40-50 m). Moth catch per trap per week was three times higher in the 4-trap fields than in the 24-trap and network fields. Reproductive success of the moth, as indicated by fruit infestation, was similar for fields with 4-traps and farmers' practice fields without traps, indicating that local depletion was cancelled out by additional attraction from surroundings. In contrast, the 24-trap setting or the network of nearby fields both sufficiently depleted the male moth population reducing fruit infestation and increasing yield compared to farmers' standard practice. Trapping in typically sized individual fields (4 trap-fields) was ineffective. For effective trapping, concerted action is needed either through neighbours with directly adjacent fields allowing an array of $4 \times 6$ traps or by farmers of nearby fields.

Chapter 6 reflects on thoughts and insights of what measures should be taken to provide a workable IPM. Using a transdisciplinary approach, I could identify the most relevant problems of farmers and seek solutions together with them. Rather than providing farmers a predefined IPM package, this study generated a basket of options for and with them. All IPM options for disease and insect management were technically and economically viable. While the combination would be most effective also sound options for partial implementation are indicated. These developed alternatives to current massive spraying might be useful for other eggplant growing areas having similar socio-economic conditions and biotic stresses. Yet, there were a few remaining bottlenecks for the use of these IPM options: unavailability of $T$. harzianum, seed treating machine and pheromone lures in the village, a mismatch between farmers' knowledge on insect biology and use of pheromone trapping, and the need for social organisation for effective trapping. Farmers are expected to adopt these IPM options only when these bottlenecks are removed. Extension and other institutional support are required.

This research will contribute to designing IPM for smallholders in developing countries. My research approach may show the way to developing or adjusting more sustainable agricultural innovations in general. Research and extension, agricultural research institutes and universities and policymakers of Bangladesh and similar countries may use this thesis to fine tune their approach to designing agricultural innovations that suit farmers' needs.

In conclusion, IPM is difficult for smallholders but not impossible if combined with integrated people management. Without proper collaboration and communication between research, extension, farmers, and the agro-input value chain it will be difficult to make IPM work for smallholders. 


\section{Acknowledgements}

At the end of this long voyage, I take the opportunity to express my gratitude to each of you who helped me to grow professionally and personally. Completing this work would not have been possible without your support, love and prayers.

First of all, I would like to express my sincere gratitude to my supervisory team: Prof. Dr Paul C. Struik, Dr Tjeerd-Jan Stomph, Dr Peter W. de Jong and Prof. Dr Mohammad Mahir Uddin. I thank each of you for your valuable guidance and inspiration.

I consider myself lucky that Prof. Paul Struik is my promotor. You are excellent. Thank you very much for your guidance, clear and concise comments on my writings, your attention to each word of the thesis. Thanks for keeping me on track to submit on time and also for your quick and timely feedback. Without this, submission was not possible. I acknowledge the way you appreciate me for every little thing; how much it motivated me is beyond words to describe.

I express my gratitude to my daily supervisor, Dr Tjeerd-Jan Stomph. Your seriousness and attention to details of the research, critical attitude towards research and excellent editorial skills make this thesis happen. I admire the way you push me to come out of my comfort zone and take up challenges. Thank you for asking me many questions and giving many comments, it helped me to be creative. I appreciate the huge time you invested in me, you made time for me no matter how busy you are. Thanks for visiting Bangladesh twice and walk in the fields with me; it gave me confidence. I am grateful to you and Leentje for inviting me many times at your home and make me feel as if I am at my home in Kuthiboyra. Most memorable one was when you and Leentje took me to the ice-cream shop. You are a fantastic supervisor. Thank you very much.

Sincere gratitude to my other supervisor Dr Peter W. de Jong. You are an excellent supervisor providing clear cut input in short meetings. I appreciate your editorial works. Thank you very much for your guidance, appreciation, daily life conversation and of course your humour. I acknowledge your mental support to me.

Sincere gratitude to my supervisor Prof. Dr Mohammad Mahir Uddin. I am thankful to you for trusting me and immediately boarding on the supervisory team when I described you the project and after I was declined by many. You have always told me that I will learn a lot from this $\mathrm{PhD}$. Thank you for your guidance, support and inspiration and walking in the Jamalpur fields with me and Tjeerd-Jan. 
I acknowledge Prof. Dr Md. Rashidul Islam and all members of his laboratory, especially Kamrul, for supporting me in in vitro and molecular studies. Thank you for your collaboration with us and I hope it will be continued. Thanks also for your faith in me.

My sincere appreciation goes to the CSA secretariat: Nicole Wolffensperger, Sjanie van Wetten, Petra Rozema and Alex-Jan de Leeuw. Thank you very much for supporting me in different ways during this $\mathrm{PhD}$ journey. I appreciate your professionalism and commitment to handling logistic, administrative and financial issues. Sjanie, Nicole and Petra, thank you very much for assigning me a beautiful desk each time I came to Wageningen. Nicole, thanks a lot for checking my thesis. Sjanie, thanks a lot for your inspiration.

It was a challenge for me to work in rural Jamalpur, however, it was joyful. Conversation with villagers and farmers gave me a new insight in life. Despite all sorts of constraints, they know the art of living happily. I am indebted to several organizations and persons who supported me along my PhD trajectory: Regional Agricultural Research Station, Jamalpur: especially Dr Md. Monjurul Kadir; Upazilla Agriculture Office, Islampur: Motiur Rahman and Lutfunnahar Lata and Sub Assistant Agriculture Officers, which and who provided me primary information and guided me to several villages. I particularly thank Nur Hossain and Nazmul Hassan. Two of my research assistants, without whom this research would have been extremely difficult: Md. Uzzal Mia, IPM farmer trainer and Raju Ahmed, a class ten student. Uzzal, your passion towards my project was tremendous, you handled everything nicely in my presence and in my absence. My heartfelt thanks to you for everything and your wife Sathi for cooking delicious food for me. I acknowledge Raju's mom and other affectionate ladies of the village for their chit-chat and love. I am indebted to all people of Pirijpur for their support, respect and for making me feel comfortable. I highly acknowledge all the farmers who participated in the study and enriched me with their knowledge, particularly: Jahangir, Nabi, Ramjan, Mintu, Kashem, Shukur, Habibur and Mafizul bhai. I am also indebted to many farmers across the villages of Islampur, Sharishabari, Melandah and Dewanganj for teaching me and informing me about various issues regarding eggplant cultivation. Particularly, I am thankful to Dulal bhai and his son Ibrahim for enthusiastically showing their fields. Walking in the fields with farmers made me realise how passionate farmers are about agriculture and how important it is for us as scientists to support them. At the end of this paragraph, I express my love to all the children of Pirijpur village who were curious about me and my bag and curiously followed me in the fields. Among those children, I share a special bond with Ali Noor. Whenever he had time, this little boy 
accompanied me in the field and energized me by his conversation. About every little task I gave him, he felt extremely proud and that gave me joy.

I am grateful to all the precious people, friends and colleagues of Wageningen University, particularly from CSA and PPS: Clara, Andre, Uta, Ioannis, Marcelo, Shiferaw, Alejandro, Kailei, Niteen, Luuk, Wenjing, Ali, Thomas A, Thomas K, Ambra, Evelien, Zishen, Israel, Phuong, Jin, Lotte K, Niharika and all the others I did not mention. Special thanks to Niharika for your love and moral support and also for suggestions on editing of the thesis, especially tables. Marcelo, thank you for your suggestion on combining thesis chapters. Ali and Zishen, thank you very, very much for being paranymph. Lotte, thanks for your smile. I express my gratitude to Wopke van der Werf and Bob Douma for discussions on pheromone trapping. I acknowledge Prof. Niels Anten, Xinyou Yin, Aad van Ast, Jochem Evers and Maja Slingerland. My special thanks to Claudius van de Vijver and Lennart Suselbeek for their support throughout the $\mathrm{PhD}$ period.

I acknowledge the support from my Bangladeshi friends and juniors here in Wageningen and in Bangladesh: Mukta Mala, Sumitra, Shishir, Sojib, Imtiaz, Palash, Rubaiat, Boby, Era and Masum, Fariha and Muktader, Julie, Sami, Tanvir, Mou and Kayesh bhai, Rumana apu, Tapos. I thank Tonmoy and Niharika for the lunch time conversations. I am grateful to a wonderful person Rajib Hossain bhai for guiding me to start running and also reading part of the introduction.

I am very grateful to all the directors and co-ordinators of Interdisciplinary Institute of Food Security (IIFS), Bangladesh Agricultural University (BAU) for their kind support. My appreciation to Haider bhai for administrative support. I acknowledge support from Dr Roel Bosma. I swam this stormy sea with fellow colleagues and their support was huge: Uttam, Lavlu, Khalid, Mousumi, Zannatun, Sharmin and Kizar: thank you very much. I acknowledge collaboration with Zannatun and Dr. Annemarie van Paassen.

I express my gratitude to all my teachers and colleagues of the Department of Entomology, BAU for their support and good wishes. I acknowledge Prof. Dr Kazi Shahanara Ahmed for being my supervisor for a year and providing various suggestions on proposal development. Dr Mahbuba Jahan madam, thank you for observing a few of the sticky traps and for identifying insects. Dr Tofazzal Hossain Howlader sir, thank you for your support when my laptop crashed. I thank all the office staff of Entomology for their support. Beyond Entomology, I am thankful to Dr Badiuzzaman Khan for showing me the basics of R. I acknowledge Dr Bahadur Meah sir 
and IPM laboratory for support in identifying fungi. Dr Israt Jahan Shelly apa for your faith and kind words towards me. Dr Mahbuba Siddiqua madam for your appreciation and affection. Dr Sabina Yeasmin Shalie for being my friend. Dr Fahmida Meem, Dr Sabina Yasmin for liking me on Facebook and in person. Sumitra Saha Sumi, for walking with me in the BAU and WUR campus and listening to my every story, thank you.

Finally I would like to thank my family for all their love and support: maa, I could not finish this thesis without your prayers, encouragement and faith in me; baba, you are not here to see me but I am sure you are proud of this achievement. All my brothers (Wazed Ali, Johurul Islam, Humayun Kabir, Liakat Ali and Anisur Rohman), sisters (Johura Bakul, Nazma Nazu), nephews and nieces, your love and support are my energy. Particularly dada bhai (eldest brother): it was impossible to stay in Jamalpur without your company. Thank you very much for listening to all my stories with patience and guiding me for prayers, meditation and yoga to keep me focused in my work and life. My niece and best friend Arefa Taposhe, thank you for sending me encouraging messages every morning while I was writing the last part of the thesis. My cousin Mohsena apa on every messenger call checking whether I am eating healthy. My other cousin Nasima apa for taking care of my Mymensingh home in my absence. Noble, Zerin, Nabil, my little Tanjim and Tawhid, thank you for loving your aunt.

Dear all, I am very glad that I was able to write this thesis which makes me more confident and resilient. Thanks very much again. I end this section of the thesis with a few lines of my favourite poet Rabindranath Tagore:

"Let me not pray to be sheltered from dangers

But to be fearless in facing them.

Let me not beg for the stilling of my pain,

But for the heart to conquer it."

Naznin

July, 2020 


\section{List of Publications}

\section{Journal articles}

Nahar, N., Uddin, M. M., de Jong. P., Struik, P. C., Stomph, T. J., 2020. Technical efficacy and practicability of mass trapping for insect control in Bangladesh. Agronomy for Sustainable Development, 40:19.

Nahar, N., Islam, M. R., Uddin, M. M., de Jong, P., Struik, P. C., Stomph, T. J., 2019. Disease management in eggplant (Solanum melongena L.) nurseries also reduces wilt and fruit rot in subsequent plantings: A participatory testing in Bangladesh. Crop Protection, 120: 113-124.

Nahar, N., Islam, M. R., Uddin, M. M., de Jong, P., Struik, P. C., Stomph, T. J., 2018. Reducing damping-off problems in eggplant (Solanum melongena L.): A participatory testing of nursery management in Bangladesh. Crop Protection, 112: 177-186.

Nahar, N. and Ohtani, T., 2015. Imidacloprid and Fipronil induced abnormal behavior and disturbed homing of forager honey bees, Apis mellifera. Journal of Entomology and Zoology Studies, 3: 65-72.

Nahar, N., 2013. Observation on Apis mellifera bee box with an emphasis to foraging behavior. Journal of the Bangladesh Society for Agricultural Science and Technology, 10: 143146.

Nahar, N., Akter, S., Mondal, F., 2008. Laboratory evaluation of extracts of turmeric powder against rice weevil, Sitophilus oryzae (Curculionidae: Coleoptera). Bangladesh Journal of Agriculturist, 1: 63-67.

Nahar, N. and Ahmed, K. S., 2007. Biological efficacy of aqueous extract of neem, Azadirachta indica leaf against Epilachna beetle, Epilachna vigintioctopunctata Fabricius. Bangladesh Journal of Crop Science, 18: 171-177.

Chakraborty, T., Nahar, N., Khatun, M. R., Das, G., 2019. Potentiality of some insect growth regulators on the mortality of bean aphid, Aphis craccivora (Koch.). Journal of Entomology and Zoology Studies, 7: 199-203.

Chakraborty, T., Nahar, N., Das, G., 2019. Insect growth regulators and their potential in reducing body weight of bean aphid, Aphis craccivora (Koch.). International Journal of Entomology Research, 4: 83-88.

Zehad, M., Nahar, N., Uddin, M. M., Khatun, M. R., Ahmad, M., Chowdhury, S. M., 2018. Comparative efficacy of some conventional and new generation insecticides for controlling brinjal shoot and fruit borer and their impact on ladybird beetle. Bangladesh Journal of Entomology, 28: 73-84. 
Mohan, S., Nahar, N, Ahmed, K. S., 2013. Effects of Cyperin 10 EC and Neem extract on pollinator abundance, fruit setting and quality of mango. Journal of the Bangladesh Agricultural University, 11: 189-192.

Akter, S., Nahar, N., Rahman, M., 2007. Effects of garlic clove, neem and eucalyptus leaf extract on mating behaviour, oviposition and adult emergence of pulse beetle, Callosobruchus maculatus. Progressive Agriculture, 18: 93-97.

Ara, S., Nahar, N., Rahman, M., 2007. Incidence and damage estimation of brinjal shoot and fruit borer in five different brinjal varieties. Progressive Agriculture, 18: 75-80.

\section{Conference proceedings}

Nahar, N., Islam, M. R., Uddin, M. M., de Jong, P., Struik, P. C., Stomph, T. J., 2017. Disease suppression in eggplant (Solanum melongena L.) nurseries carries over to reduced wilt and fruit rot in subsequent plantings. Future IPM in Europe 3.0: Towards a sustainable Agriculture. Riva del Garda, Italy, October 16-20, 2017. (Poster presentation)

Nahar, N., Islam, M. R., Uddin, M. M., de Jong, P., Struik, P. C., Stomph, T. J., 2018. Disease suppression in eggplant (Solanum melongena L.) nurseries carries over to reduced wilt and fruit rot in subsequent plantings. The first International Congress of Biological Control, Beijing, China, May 14-16, 2018. (Oral presentation) 


\section{PE\&RC Training and Education Statement}

With the training and education activities listed below the $\mathrm{PhD}$ candidate has complied with the requirements set by the C.T. de Wit Graduate School for Production Ecology and Resource Conservation (PE\&RC) which comprises of a minimum total of 32 ECTS (= 22 weeks of activities)

\section{Review of literature (6 ECTS)}

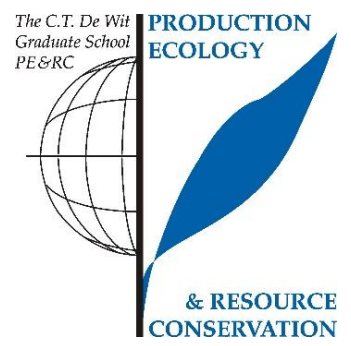

- Eggplant cultivation and massive pesticide use in Bangladesh: results from poor adoption of IPM

\section{Writing of project proposal (4.5 ECTS)}

- Designing IPM for eggplant in Bangladesh

\section{Post-graduate courses (6.9 ECTS)}

- Competence for integrated agricultural research for integrated management of cropfish-water resources to enhance agricultural production system towards sustainable food security in Bangladesh; WASS and CDI, WUR (2014)

- Bugs at your service: Fundamentals and applications of arthropod-mediated ecosystem services; PE\&RC (2014)

- Introduction to R for statistical analysis; PE\&RC and SENSE (2014)

- Advanced statistics course design of experiments; PE\&RC and WIAS (2016)

- Qualitative data analysis with Atlas.ti: a hands-on practical; WASS (2016)

- Gender, agriculture and rural development; ICF-BAU, CDI-WUR (2016)

- Interdisciplinary research; ICF-BAU, CDI-WUR (2017)

\section{Laboratory training and working visits (3.3 ECTS)}

- Professional capacity building programme on design and implementation of interdisciplinary team research; CDI, WUR in field training Bangladesh (2013)

\section{Invited review of (unpublished) journal manuscript (1 ECTS)}

- Journal of Agriculture and Technology Management: study on seed quality characters of Corchorus spp. collected from different sources in Bangladesh

\section{Deficiency, refresh, brush-up courses (12 ECTS)}

- Academic consultancy training version research proposal development; WUR (2014)

- Basic statistics; PE\&RC (2014)

- Application of statistical methods for agricultural data by SPSS; ICF, Bangladesh Agricultural University (2016)

\section{Competence strengthening / skills courses (5.3 ECTS)}

- Techniques for writing and presenting a scientific paper; WGS (2014)

- Project and time management; WUR (2014) 
- Information literacy PhD including end note introduction; WUR Library (2014)

- Data management planning; WUR Library (2014)

- Competence assessment; WGS (2014)

- The essentials of scientific writing and presenting; Wageningen in'to Languages (2016)

- Presenting with impact; Wageningen in’to Languages (2018)

PE\&RC Annual meetings, seminars and the PE\&RC weekend (2.7 ECTS)

- PE\&RC Weekend for first years (2014)

- PhD Workshop carousel (2014)

- PE\&RC Day: optimization of science: pressure and pleasure (2014)

- PE\&RC Weekend for last years (2017)

- PE\&RC Day: exploring sustainability (2019)

\section{Discussion groups / local seminars / other scientific meetings (5.7 ECTS)}

- Interdisciplinary discussion group, NICHE-BGD; WUR; Food Security in Bangladesh (2014)

- CoS-SIS (Convergence of Science) seminar: science for impact; PE\&RC, WUR (2014)

- Interdisciplinary discussion group; Interdisciplinary Centre for Food Security (ICF), Bangladesh Agricultural University, BAU (2015-2016)

- Interdisciplinary research and education at BAU and ICF: experiences and preliminary results (2017)

- Wageningen $\mathrm{PhD}$ symposium (2019)

\section{International symposia, workshops and conferences (4.2 ECTS)}

- Future IPM in Europe; poster presentation; Riva del Gerda, Italy (2017)

- The first international congress on biological control; oral presentation; Beijing, China (2018) 
Naznin Nahar (naznin.nahar@bau.edu.bd) was born in Tangail district, Bangladesh. She grew up in Kuthiboyra, a beautiful village of Bhuapur Upazilla, Tangail where she attended elementary and high school, while she did her higher secondary studies in the Upazilla town. She completed her Bachelor of Science in Agriculture and Master of science in Entomology at the Bangladesh Agricultural University (BAU), Mymensingh. During her masters, Naznin read Rachel Carson's 'Silent Spring' which made her decide that Integrated Pest Management would be her future research interest. For her Master's thesis, she studied botanical-based management of the Epilachna beetle. In recognition of

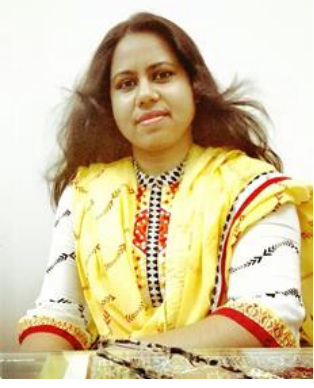
academic excellence, Naznin achieved a government scholarship throughout her academic career and was awarded Prof. Jinnat Ara Begum gold medal from BAU. In 2006, she joined the Department of Entomology, BAU as lecturer.

In 2009, Naznin received an Asian Youth Fellowship funded by The Japan Foundation. In The Japan Foundation Japanese-Language Institute, Kansai she received training on Japanese language and culture and leadership development for regional cooperation to create social impact. There she met many youth from across the globe and became acquainted with the diversity of cultures of the globe. In 2010, Naznin obtained a Monbukagakusho scholarship funded by The Ministry of Education, Culture, Sports, Science and Technology (MEXT), Japan, to pursue a second Master of Science at Kobe University. She combined laboratory field experiments in the beautiful garden of Kobe University and The Museum of Nature and Human Activities, Hyogo to investigate the reasons for the colony collapse disorder in honeybees.

In 2014, Naznin joined the Centre for Crop Systems Analysis (CSA), Wageningen University and Research (WUR) as a $\mathrm{PhD}$ candidate, funded by the NUFFIC-NICHE-BGD-156 project, a collaboration between WUR and BAU. In her PhD project, Naznin focused on designing integrated pest and disease management with and for farmers, using eggplant cultivation in Bangladesh as case-study. In 2017, she received the best poster award in the 'Future IPM conference' held in Italy.

Naznin is currently working as an Associate Professor with the Department of Entomology, BAU. She is involved in three undergraduate courses: Fundamentals of Entomology, Insect Ecology and Pest Management, and Economic Entomology. She also supervises Master students in their research projects. Naznin was and is involved in several IPM projects as Co-Investigator funded by the Ministry of Science and Technology, the Ministry of Education and the Bangladesh Agricultural University Research System (BAURES). She will continue her research on IPM for smallholder farmers.

Naznin loves reading novels and poems and writes herself too. Writings of Rabindranath Tagore and Jalal-Ad-Din Muhammad Rumi inspire her a lot. She has a plan to write a novel based on her $\mathrm{PhD}$ memories which she wishes to publish. She wishes to travel to all districts of Bangladesh to gain more insight into rural life and pick up research questions from farms and farmers for future research. 


\section{Funding}

The research presented in this thesis was funded by NUFFIC (The Dutch Organization for Internationalization in Education), The Netherlands, under its NICHE program (grant number NUFFIC-NICHE-BGD-156), a collaboration between Wageningen University and Research (WUR) and Bangladesh Agricultural University (BAU). Printing of this thesis was funded by Wageningen University and, in particular, the Centre for Crop Systems Analysis.

\section{Cover design and printed by}

GVO drukkers \& vormgevers B.V. Ede, The Netherlands 



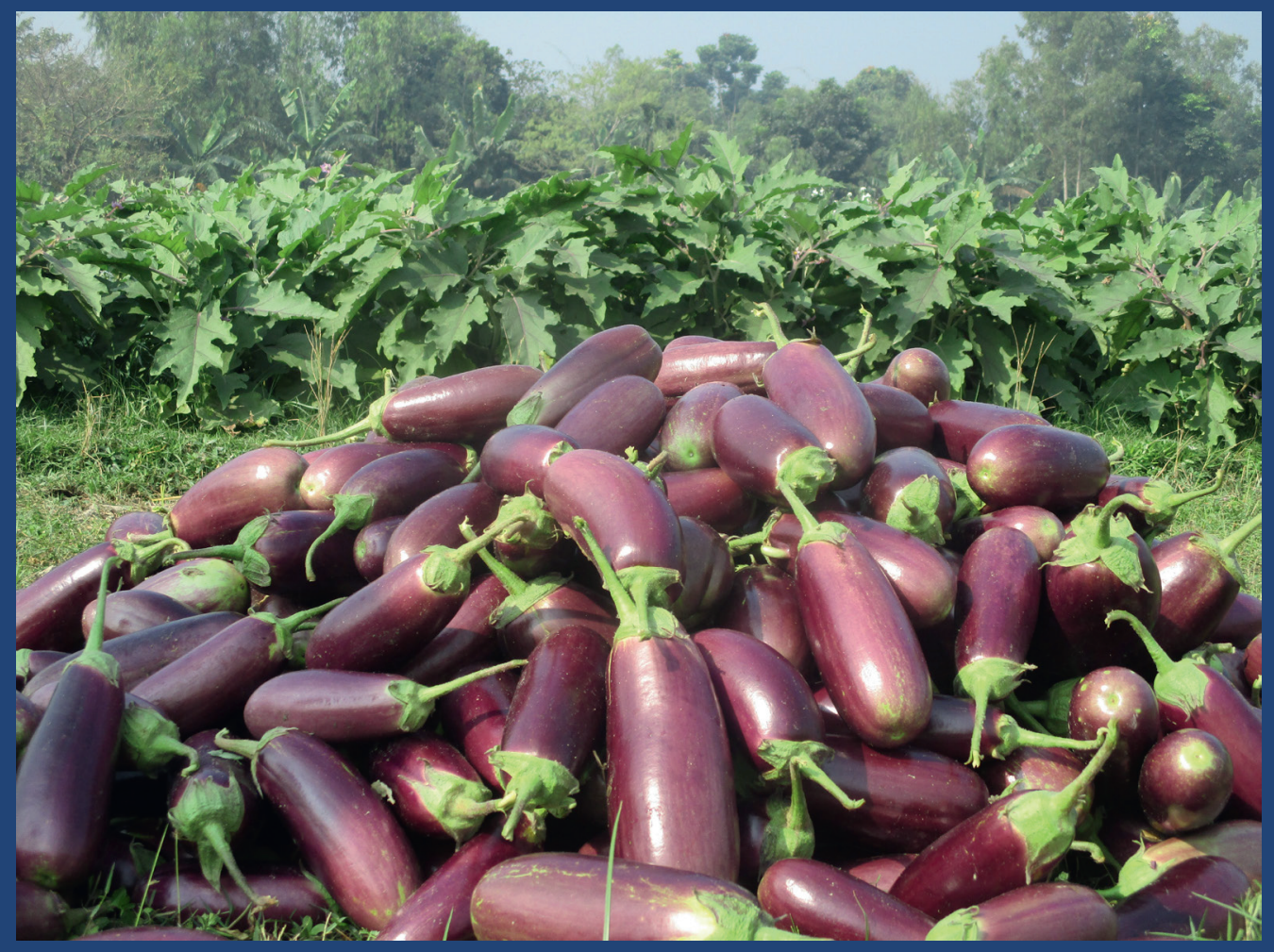

